Historic, archived document

Do not assume content reflects current scientific knowledge, policies, or practices. 
UNITED STATES DEPARTMENT OF AGRICULTURE Miscellaneous Publication No. 698

WASHINGTON, D. C.

$8-707$

April 1950

A REVISION OF THE

NORTH AMERICAN SPECIES OF BEETLES

BELONGING TO THE FAMILY

BOSTRICHIDAE

By

W. S. FISHER

Entomologist, Division of Insect Identification

Bureau of Entomology and Plant Quarantine

Agricultural Research Administration

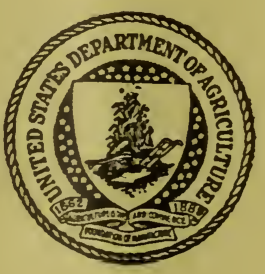

For sale by the Superintendent of Documents, U. S. Government Printing Office 



\section{A REVISION OF THE NORTH AMERICAN SPECIES OF BEETLES BELONGING TO THE FAMILY BOSTRICHIDAE}

By W. S. FishER, entomologist. Division of Insect Identification, Bureau of Entomology and Plant Ouarantine. Agricultural Research Administration

\section{CONTENTS}

Introduction

Key to the subfamilies and tribes of Bostrichidae.

Subfamily Dysidinae

Subfamily Psoinae

Tribe Polycaonini

Tribe Psoini

Subfamily Endecatominae

Subfamily Dinoderinae.

\section{Page}

1 Subfamily Bostrichinae ....... Tribe Dinapatini ...........

2 Tribe Bostrichini Tribe Nyloperthini

Addenda ....................

Index to species
Index to host plants and commercial products. l'age

51

51

52

101

143

145

153

\section{INTRODUCTION}

This publication summarizes the resuits oi serera ${ }^{2}$ yerrs study of the beetles of the family Bostrichidae and treats all the species of the family known to occur in America north of Mexico and including Lower California. In addition. a number of exotic species. int sreepted from time to time in imports from foreign comtries. are included in anticipation of the necessity of correctly identifying such material. In all. 32 genera and 22 species are considered. So far as is known. 29 of these species have not become established in the United States. Eight species are described as new.

From a utilitarian point of riew the family Bostrichidae is one of the most destructive families of the Coleoptera. A number of the species cause considerable damage to stored regetable products. such as dried roots and all kinds of grain. Members of the family are especially destructive in the Tropics, where they cause great damage to felled timber and bamboo, particularly in regions where bamboo is widely used in construction of buildings and furniture. It has been commonly supposed that bostrichids were simply wood borer's and did no damage to living trees. Recently, however, it has been e-tablished that many species will attack and oviposit in weakened standing green trees. Some species have the damaging habit of tumeling into the green shoots of plants, either for food or for hibernation. 'The mropensity for members of this family to burrow in wood products. such as packing cases and articles made of bamboo. has resulted in their being widely distributed through commerce.

This study, which has been made almost entirely from material in the United States National Museum, was undertaken becaure of the 
need for a comprehensive and up-to-date treatment of this economically important family. Lesne's excellent revision of the known species of this family, published between 1896 and 1906, is not always available to American students of the group. Furthermore, although Lesne established a number of new genera in this work, he neglected to designate genotypes, with the result that there has been some difference of opinion among subsequent workers as to the application of certain generic names. Lesne treated the Lyctidae as a subfamily of the Bostrichidae, but the author of this publication prefers to follow Kraus ${ }^{1}$ and consider the Lyctidae as a separate family.

Members of this family are elongate, cylindrical in form. They greatly resemble and are often mistaken for Scolytidae. From the Scolytidae they may usually be distinguished by their tuberculate and rasplike pronotum, by their straight instead of elbowed antennae with a 3 - or 4-segmented club, and by their 5-segmented tarsi. The outer surface of these beetles is very hard, and all parts fit closely together as is usually the case with wood-boring beetles. The prothorax is occasionally furnished with hooks or frontal teeth in addition to the rasplike tubercles, and the posterior part of the elytra is frequently provided with one or more tubercles. These latter structures are probably used by the beetles in moving about in their tunnels. The femora and tibiae are broad, the latter frequently toothed on one margin. Some species exhibit sexual dimorphism and have the hooks and teeth of the pronotum and the tubercles of the elytra curiously modified.

\section{KEY TO THE SUBFAMILIES AND TRIBES OF BOSTRICHIDAE}

1. Head not deeply inserted in the prothorax, visible from above Head deeply inserted in the prothorax, not visible from above.......

2. Front of head produced into a lobe on each side of clypeus; disk of pronotum tuberculate ..................... DYSIDINAE, p. 3.

Front of head not produced into a lobe on each side of the clypeus; disk of pronotum not tuberculate _...

3. Anterior coxae distinctly separated by the prosternal lobe; anterior tibiae with a large arcuate spine at apices _....... POLYCAONINI, p. 5.

Anterior coxae not or only partially separated by the prosternal lobe; anterior tibiae without a large arcuate spine at apices_- PSOINI, p. 15.

4. Pronotum completely margined laterally - ENDECATOMINAE, p. 19.

Pronotum not completely margined laterally, rarely with a distinct lateral carina on each side posteriorly

5. Posterior tarsi shorter than tibiae; pronotum rounded or ogival, rarely truncate, in front ....... DINODERINAE, p. 23.

Posterior tarsi as long as, or longer than, tibiae (not quite so long in some specimens of Apatides fortis (Lec.), but then the pronotum is emarginate in front); pronotum truncate or emarginate in front

BOSTRICHINAE, p. 51.

6. First and second segments of antennal club compressed or flabellate....

First and second segments of antennal club caliciform (cup-shaped) DINAPATINI, p. 51.

7. Intercoxal process of abdomen tabular ( $T$-shaped) or triangular BOSTRICHINI, p. 53. Intercoxal process of abdomen lamellate (I-shaped) XYLOPERTHINI, p. 101.

\footnotetext{
${ }^{1}$ KraUs, E. J. III.-A Revision of the Powder-Post beEtles of the FaMILY lyctidae of the united states and europe. U. S. Dept. Agr. Ent. Tech. Bul. 20, pp. 111-138. 1911.
} 


\section{Subfamily DYSIDINAE}

Dysididae Lesne, 1921, Assoc. Franc. pour l'Avanc. des Sci., Cong. de Strasbourg (1920), p. 286.

Dysidinae Lesne, 1938, in Junk (pub.), Coleopt. Cat., pt. 161, p. 4.

Apoleoninae Gardner, 1933, Indian Forest Rec., Ent. Ser. 18 (9) : 3 (larvae).

This subfamily contains but two genera, Dysides Perty and A poleon Gorham, the former distributed throughout South America and the latter restricted to the oriental regions.

\section{Genus DYSIDES Perty}

Dysides Perty, 1832, Delectus Animalium Articulatorum Ins. Brasil, p. 113, pl. 22, fig. 14; Silbermann, 1833, Rer. d'Ent. 1 : 265 ; Westwood, 1835, Mag. Zool.. C1. 9, pl. 123; Guérin-Ménéville, 1844, Icon. Regnè Anim., v. 3, Insectes p. 188; 1845 , Soc. Ent. de France Ann. (ser. 2) 3: Bul. p. xvii ; Lacordaire, 1857, Genera des Coléopt., v. 4, pp. 519, 527-52s; Lesne, 1S94, Soc. Ent. de France Ann. 63: 18-21; 193S, in Junk (pub.), Coleopt. Cat., pt. 161, p. 4.

Head strongly convex, not covered by the prothorax, completely visible from above, the front prolonged forward forming a lobe on each side of clypeus; clypeus strongly transverse, emarginate in front; labrum small, partially covered by clypeus; maxillary and labial palpi subequal to each other in length, apical segments of maxillary palpi broad, elongate, broadly rounded or subtruncate at apices, apical segments of labial palpi narrowly oblong, rather acute at apices; mandibles large, robust, acute at apices, bidentate on inner margins, densely pubescent posteriorly ; eyes large, round, globose, strongly projecting. Antenna 9-segmented; first segment robust, elongate, sides nearly parallel, densely clothed with stiff hairs; second segment narrow, expanded toward apex, subequal in length to the following two segments united; third to sixth segments round, subequal in length; last three segments forming a large, loose club, with numerous small sensory depressions on each surface, and with a few erect blackish hairs. Pronotum moderately convex, uneven and irregularly tuberculate on top, truncate at base, truncate or broadly, arcuately emarginate at apex, without distinct lateral margins. Scutellum subtriangular, elongate, broadly rounded at apex. Elytra moderately convex, without longitudinal carinae. Legs long, subequal in length; tibiae with sides nearly parallel, not distinctly dentate on exterior margins, anterior pair with three spines at apices, a small, arcuate one on outer margin and two unequal ones on inner margin; tarsi 5 -segmented; posterior pair shorter than tibiae, last segment subequal in length or slightly longer than first. Anterior coxae contiguous. Middle coxae narrowly separated. Intercoxal process of abdomen broadly triangular. Body elongate, moderately depressed.

Genotype.-Dysides obscurus Perty. (Monobasic.)

The genus Dysides was founded by Perty (1832) for his new species obscurus from Brazil.

There is considerable discussion on the systematic position of this genus. Perty placed it with some doubt between the "Ptiniors" and "Clerides." Silbermann (1833) placed it in the Anobiidae near Anobium, stating that the tarsi have five segments, but the antemna have only nine segments. Westrood (1835) placed it near A pate and Psoa. Guérin-Ménéville (184t) placed it in Bostrichidae near Psoa and Heterarthron. Lacordaire (1857) placed it near the end of the Anobiidae close to the Bostrichidae. Lesne (1921) erected the 
new subfamily Dysidinae for Dysides Perty (1832) and Apoleon Gorham (1885), and (1938) placed the Dysidinae in the Bostrichidae between the subfamilies Euderiinae and Endecatominae. Since the beetles of Dysidinae do not have the head deeply inserted in the prothorax and it is distinctly visible from above, this subfamily is also closely allied to Psoinae.

\section{Dysides obscurus Perty}

Dysides obscurus Perty, 1832, Delectus Animalium Articulatorum Ins. Brasil, p. 113, pl. 22, fig. 14; Westwood, 1835, Mag. Zool., Cl. 9, pl. 123; Lesne, 1894, Soc. Ent. de France Ann. 63: 18-21; 1938, in Junk (pub.), Coleopt. Cat., pt. 161, p. 4.

Male.-Uniformly dark to light reddish brown, except palpi and antennae, which are brownish yellow.

Head densely, rather coarsely granulose on front, very finely, sparsely granulose on occiput, the granules round on front and transverse on occiput, densely clothed with short, erect, arcuate, whitish hairs; clypeus concave, broadly, shallowly emarginate in front, densely, finely rugose or granulose, densely clothed with short, erect, arcuate, whitish hairs; clypeal suture distinct, curved forward between sides of clypeus and lateral lobes; labrum smooth at middle. Antennal club with the segments narrowly oblong, second and third segments petiolate at bases, the third distinctly longer than second, and narrowly rounded at apex.

Pronotum :much wider than long, widest along basal half, with a narrow, transverse groove along base, a triangular, median flattened space along anterior margin, and a narrow. longitudinal, median groove on basal half; sides parallel on basal half, arcuately converging: anteriorly, with a number of small tubercles near margins; posterior angles rectangular, each with four teeth; disk with four rather acute, erect tubercles, placed in a transverse row near middle, and a few smaller tubercles scattered over apical half, surface finely densely granulose, the granules distinctly separated, densely, uniformly clothed with short, erect, arcuate, whitish hairs.

Elytra at base subequal in width to pronotum along basal half; sides gradually expanded to apical fourth, then arcuately converging to the apices, which are separately rounded; apical declivity regularly. arcuately deflexed: surface densely, finely, uniformly punctate, finely granulose on basal region, densely, uniformly clothed with short, erect, blackish hairs (with whitish and blackish hairs intermixed on the pale brown specimens).

Abdomen beneath densely, finely punctate, densely, uniformly clothed with short, erect hairs, similar to those on dorsal surface of elytra; last visible sternite broadly depressed at middle, broadly rounded at apex, and clothed with longer, erect, black hairs.

Female.-Differs from the male in having the clypeus bilobed and deeply, broadly, arcuately emarginate in front, the segments of the antennal club robust, with the first and second segments subtriangular and subequal in length to each other, and the third segment oblong, longer than the eighth, and subtruncate at the apex, and the last visible abdominal sternite without a median depression.

Length 5-14 mm., width 4-4.5 mm.

Type locality.-Piauhy Province, Brazil; present location of the type is unknown to the writer. 
Distribution.-This species is recorded in the literature from Venezuela. Brazil. Bolivia. and Guiana.

So far as known this species has not become established in the United States. but adults have been intercepted at Hoboken. N. J.. with orchids from Venezuela and in a softwood board from Colombia, South America. Nothing is known about the habits of this species. but D'Orbigny reported collecting adults on a dead tree at Guarayos, Bolivia. during December. Testrood (1535) recorderl a specimen in the Guilding collection from Saint Vincent Island, but the locality is somerhat doubtful.

\section{Subfamily PSOINAE}

\section{Tribe Polycaomin}

Polycanonini Lesne, 1921, Assoc. Franc. pour l'Arince l ss Sic... Conc. de Strasbourg $(1920)$, p. 257.

Polrcaoninae Lesme, 1896. Soc. Ent. de France Ann. (i-): (6. 111-125.

Psoini Leconte. 1861, Smithsn. Inst. Misc. Collect. 3 (1) : 207, 208 (part) ; Holn, 1578, Amer. Phil. Soc. Proc. 17: 540, 551 (part); Loconte and Horn, 1883, Smithsn. Inst. Misc. Collect. $507: 227$ (part).

Psoidae Böring and Craighead, 1931, Ent. Amer. (n. s.) 11: 62 (part) (larvae). Psoinae Gardner, 1933, Indian Forest Rec. Ent. Ser. 18 (9) : 3, 4 (larrae) ; Anderson, 1939, Wrash. Acad. Sci. Jour. 29: 388-390 (part).

This tribe contains two genera, both of which are represented in the United States.

\section{KEY TO THE GENERA OF POLYCAONINI}

Anterior tibia strongly emarginate at base; sides of pronotum flattened.................................. Melalgus Dejean, p. 5.

Anterior tibia not emarginate at base; sides of pronotum convex..................................... Polycaon Castelnau, p. 11.

\section{Genus MELALGUS Dejean}

Melalgus Dejean, 1835, Cat. Coléopt., ed. 2, p. 309 ; 1836, edl. 3 rer., p. 334; Sturm. 1S13, Cat. Käter sammlung, p. 231.

Heterarthron Dejean, 1s:36, Cat. Coléopt., ed. 3 rer., p. 334; Guérin-ırénérille, 1854, Icon. Règne Anim. Ins., r. 3, pp. 1Sï-1Sт; 1S1.5. Soc. Ent. d, France Amn. (ser. 2) 3: Bul., 1. xvii : I.esne, 1s!, s, Soc. knt. de France Ann. 64: 169, note 2; 1996, 65: 111, 114-125; 1906, 75: 394-399: 1925, Encrc. Ent. (ser. B). Coléopt. 1: 31; 1935, in Junk (pub.), Coléopt., Cat., pt. 1u1, 11. 2-'-29 : Bellin. 1940, Ent. News 51: 193.

Exopioides Guérin-liénéville. 18s4, Icon. Règne Anim. Ins., v. 3, pp. 15i-18s: 1St5, Soc. Ent. de France Ann. (ser. 2) 3: Bul. p. xvii : Horn, 1sis, Amer. Phil. Soc. Proc. 17 : 5.51, 554 ; Lesne, 1896, Soc. Ent. de France Ann. 65 : 111. 114 : 1913, Soc. Ent. de France Bul., p. 194.

Polycaon Horn, 1sis, Amer. Phil. Soc. Proc. 17: 5.j1-jt (part).

Head strongly conrex, not coreled by prothorax, completely visible from above: clrpeus large. broadly transverse, separated from front of head by a more or less distinct suture: labrum broadly transverse, partially corered by clypeus, truncate or emarginate in front: mentum strongly transverse, more or less emarginate in front: maxillary and labial palpi subequal in length, (lensely pubescent, apical segment of each narrowly oblong, rather acutely round at apes. mandibles robust, asymmetrical ; eyes round or oblong. globose, strongly projecting. Antenna short, 10- or 11-secmented: first segment oblong. longer than second; second to serenth or eighth segments short; last 
three segments forming a loose club, which is as long as or longer than funicle, first two segments subtriangular, last segment oblongoval. Pronotum moderately convex, truncate at base and apex, without gibbosities or dentiform tubercles, and without distinct lateral margins; sides flattened or feebly concave. Scutellum (visible part) quadrate or slightly transverse. Elytra moderately convex, with or without longitudinal carinae on apical declivity. Legs long; anterior tibia emarginate at base, strongly dentate on outer margin, with two spines at apices, a large, arcuate one on inner margin and a short, straight one on outer margin; tarsi 5-segmented, posterior pair as long as or longer than tibiae, last segment of each shorter than the preceding four segments united, second and third segments flattened and expanded toward apices. Anterior and middle coxae separated. Body elongate, cylindrical.

Genotype.-Of Melalgus, Bostrichus femoralis Olivier. Of Heterarthron, B.ostrichus femoratis Olivier. (Designated by GuérinMénéville.) Of Exopioides, Exopioides carinatus Guérin-Ménéville. (Monobasic.)

This genus contains 24 described species, most of which are found in America, although a few species have been described from Asia. The sexual dimorphism of the species of this genus makes their study very difficult.

Melalgus Dejean (1835) is a valid genus based upon gonagra Fabricius, with Bostrichus femoralis Olivier listed as its synonym, and two undescribed species, chilensis Lacordaire and cylindricus Dejean. Dejean (1836) included the same species under Melalgus, but also placed Heterarthron Guérin (nomen nudum) as a synonym of that genus; therefore Heterarthron Dejean attains validity by citation in synonymy. Sturm (1843) placed Heterarthron as a synonym of Melalgus Dejean. Since Guérin-Ménéville (1844) has discussed the two genera Melalgus and Heterarthron and has designated Bostrichus femoratis Olivier as the genotype of Heterarthron, this species automatically becomes the type of Melalgus (Article $30 \mathrm{f}$ of the International Code). Guérin-Ménéville (1844) erected Exopioides for Exopioides carinatus, his new species from Bolivia. Lesne (1896) placed Exopioides as a synonym of Heterarthron. Lacordaire (1857) united Heterarthron and Polycaon, but Lesne (1925) in discussing Van Dyke's remarks about granulatus connecting Polycaon and Heterarthron, states that the form of the anterior feet and propleura of the prothorax form good characters for separating the two genera.

\section{KEY TO THE SPECIES OF MELALGUS}

1. Antenna 11-segmented; elytral declivity carinate at sides..............

Antenna 10-segmented; elytral declivity not carinate at sides

2. Marginal carina on elytral declivity short, extending to middle of declivity, the tip closer to lateral margin than sutural margin; punctures on elytra arranged in rows_..._...........

Marginal carina on elytral declivity long, extending nearly full length of declivity, the tip (when viewed from above) midway between lateral and sutural margins; punctures not arranged in rows_plicatus (LeConte), p. 7.

3. Eyes separated on front (when viewed from front) by at least six times their own diameter; pronotum not distinctly wider than long; elytra granulose toward sides and apices_._._confertus (LeConte), p. 9.

Eyes separated on front by three times their own diameter; pronotum distinctly wider than long; elytra not granulose toward sides or apices... 10. 


\section{Melalgts exests (LeConte)}

Exops exesus LeConte, 18.58, Acad. Nat. Sci. Phila. $\mathrm{X}$ : 74.

Polycaon exesus Horn, 1s78, Amer. Phil. Soc. Proc. 17: 552, 553; Gorham, 1883, Biol. Centr.-Amer., Coleopt., r. 3, pt. 2, pp. 210-211, pl. 10, figs. 18-19.

Heterarthron exesus Lesne, 1906, Soc. Ent. de France Ann. 75: 394, 396; 1935, Paris IIus. d'Hist. Nat. Arch. (ser. 6) 12: 429, fig. T (Tricent. vol.) ; 1938, in Junk (pub.), Coleopt. Cat., pt. 161, p. 28; 1939, Rer. Française Ent. 6: 95-97: Belkin, 1940, Ent. News 51:193.

Heterarthron femoralis Lesne (not Fabricius), 1896, Soc. Ent. de France Ann. 65 : 15, 18-19, figs. 5, 6, pl. \&, fig. 2, pl. 9, figs. 17-19 (part).

The writer has not examined any specimens of this species, and it is placed in the key entirely upon the characters given in the original description and by other writers. The following is a copy of LeConte's original description:

Exops exesus, ater, capite confertissime granulato, thorace latitudine haud breriore conrexo, postice parum angustato, lateribus rectis, angulis omnibus rotundatis, granulato-punctato, modice canaliculato, elytris thorace sesqui latioribus crlindricis antice truncatis, fortiter cribratim postice confluenter punctatis et sensim granulatis, postice oblique declivibus et linea elerata arcuata notatis, antennis ferrugineis. Long. .47.

Ringgold Barracks, Texas. Mr. Haldeman. The posterior curred elerated line of the elytra becomes marginal near the apex, but anteriorly bends inwards so as to define the oblique declirity. The curious species is in the transition from Exops towards Apate and allied genera.

Type.-In the LeConte Collection in the Museum of Comparative Zoology. Cambridge, Mass.

Distribution.-This species is distributed throughout southern Texas, Lower California. Mexico, and Central America. Lesne (1939) gives the distribution as follows:

TExas : Ringgold Barracks on the Rio Grande.

Mexico: Cocula, Zumpango, Oaxaca, Juchitan, Vera Cruz, Cordoba, Tehuantepec, Chiapas, and Tapachula.

Guatemala : Torola and San Geronimo.

Hoxptras : Amapala.

NicARAgUA: Managua and Contales.

Costa Rica: Surubres, San Mateo, La Uruca, Turrialba, and San José.

Hosts.-Nothing has been recorded on the host plants of this species.

\section{Melalgls plicatus (LeConte)}

Polycaon plicatus LeConte, 157t, Amer. Ent. Soc. Trans. 5: 65-66; Horn, 1878, Amer. Phil. Soc. Proc. 17: 5.52, 5.53-5.54; Gorham, 1883, Biol. Centr.-Amer., Coleopt., г. 3, pt. 2, p. 211.

Heterarthron plicatus Lesne, 1896. Soc. Ent. de France Ann. 65: 115, 119-120 (part) ; 1937, Paris IIus. d'Hist. Nat. Bul. (ser. 2), 9: 5; 1938, in Junk (pub.), Coleopt. Cat.. pt. 161, p. 2s: Anderson, 1939, Wash. Acad. Sci. Jour. 29 : 358, fig. 18 (larrae).

Polyca on obliquus LeConte, 1574, Amer. Ent. Soc. Trans. 5: 66; Holn, 1s 7 , Amer. Phil. Soc. Proc. 17 : 552, 553.

Male.-Elongate, cylindrical, uniformly reddish brown to brownish black.

Head in front subequal in width to pronotum at apex, strongly convex posteriorly, vaguely flattened along anterior margin at middle. densely, finely. uniformly granulose, rather densely clothed with moderately long, semierect, vellowish hairs. with a few long, erect. yellowish hairs intermixed: clypeus convex. broadly, vaguely emarginate or truncate in front; labrum slightly flattened, broadly, arcuately emarginate in front; eyes separated on the front (when viewed 
from above) by at least six times their own diameter. Antenna short, 11-segmented, with a few long and short, erect hairs intermixed; third segment subequal in length to fourth.

'Pronotum quadrate, widest near apex, broadly depressed along anterior margin, with a narrow, longitudinal line on basal two-thirds; sides rounded near apical angles, obliquely narrowed posteriorly, coarsely, densely punctate on disk, coarsely, densely granulose on deflexed sides, rather densely clothed with moderately long, semierect, yellowish hairs, with a few long, erect, yellowish hairs intermixed.

Elytra at base distinctly wider than pronotum at abex, strongly obliquely declivous posteriorly; sides parallel, broadly conjointly rounded at apices; surface coarsely, sparsely, irregularly punctate at base and along sutural margins on basal half, nearly impunctate posteriorly, with a number of short, transverse, parallel plicae on each side, nearly glabrous on apical declivity, but sparsely clothed with short, recumbent, yellowish hairs at sides; apical declivity with sutural margins elevated and each with a strongly elevated, marginal carina, extending nearly full length of declivity, the tip midway between lateral and sutural margins when viewed from above.

Body beneath densely clothed with long, recumbent and semierect, yellowish hairs, densely, rather finely punctate except on abdomen, where it is very finely, confluently punctate; arcuate spine at apex of anterior tibia extending nearly to middle of second tarsal segment.

Female.-Differs from the male in having the front of head uniformly convex and not flattened at middle, the eyes separated on the front by about four times their own diameter, the pronotum more vaguely depressed along the anterior margin and the surface densely. confluently punctate or granulose on the disk. the elytra uniformly. finely, densely cranulose, punctate, or rugose, and rather densely clothed with short and long, erect, yellowish hairs, which are more erect on the apical declivit $v$. The arenate spine at the apex of anterior tibia about as long as the fixst tarsal segment.

I ength $7.5-15 \mathrm{~mm}$., width 2-5 $\mathrm{mm}$.

Type locality.-Of plicatus and obliqu's. Texas, ro de inite localitv: types in the IeConte Collection in the Museum of Comparative Z ology, Cambridge. Mass.

Distribution.-From material examined:

Georgia : S?rannah, April 10, 1896. in fig stem.

Texas: Brownsville, March 28, 1895 (C. H. T. Townsend) ; March 23, 1936 (P. A. Glick) ; May 21-June 2, 1904 (H. S. Barber) ; (C. Schaeffer, E. Schwarz and H. F. Wickham). San Diego (Hubbard and Schwarz). Victoria, March 23 (E. A. Schwarz). Kingsville, March 6, 1920 (M. M. High). San Antonio, March 17, 1908 (W. D. Pierce). Alice, March 23, 1905 (W. E. Hinds). No locality (F. H. Chittenden, C. V. Riley and G. W. Belfrage).

Gorham (1883) recorded this species from Cordova and Peras, Mexico.

Hosts.-This species has been resred from fig, cotton, and huisache (Acacia farnesiana (Linnaeus) Willdenow) stems and from the dead limbs of Roval Poinciana in the Brownsville. Tex., region.

LeConte (1874) described plicatus from a single male and obliquus from a single female, both collented by G. W. Belfrage at an umrecorded locality in Texas. Forham (1883), rccognizing obliquus as the female of plicatus, placed it as a synonym of plicatus. 


\section{Melalgus confertus (LeConte)}

Poiycuon confertus LeConte, 1S66, Smithsn. Inst. Misc. Collect. 167: 103 ; Horn, 1578, Amer. Phil. Soc. Ploc. 17: 5.52, 554; Riley, 1852, Amer. Nat. 16: 747; Lintnel, 1896, ․ I. State Mus., Rpt. 49 (1895), p. 268; Fall, 1901, Calif. Acad. :ci., Uccis. Papers S: 25, 134; Herbert, 1920, Jour. Econ. Ent. 13: 360-361. IIeterarthron confertus Lesne, 1896, Soc. Ent. de France Ann. 6.5: 114, 116-117, 125; 193s, in Junk (pub.), Coleopt. Cat., pt. 161, p. 2- ; Anderson, 1939, Wash. Acad. sci. Jour. 29: 3ss, figs. 19-20.

Exopioides incisa LeConte, 1S68, Amer. Ent. Soc. Trans. 2: 64; Horn, 1Sis, Amer. Phil. Soc. Proc. 17: 55 4.

Male.-Elongate, cylindrical, uniformly reddish brown, sometimes underside of body darker, and antennae, palpi, and tarsi slightly paler.

Head in front subequal in width to pronotum at apex, strongly conrex, with a narrow, longitudinal, median line on occiput, finely, densely granulose, sparsely clothed with short, inconspicuous, recumbent hairs, with a few long, erect, black hairs intermixed; clypeus flattened or broadly, feebly, transversely concave at middle, broadly, slightly, arcuately emarginate or subtruncate in front; labrum transversely concave, deeply, broadly emarginate in front; eyes separated on the front by at least six times their own diameter. Antenna 10segmented, with a few long and short, erect hairs intermixed.

Pronotum quadrate, at most only slightly wider than long, widest near apex. broadly, raguely. transversely depressed along anterior margin, with a narrow. longitudinal median line on basal two-thirds; sides rounded near apical angles, obliquely narrowed posteriorly ; surface finely, densely granulose, rather densely clothed with short, recumbent, yellowish hairs, with a few long, erect, black hairs intermixed.

Elytra at base slightly wider than pronotum at apex, arcuately declivous posteriorly; sutural margins slightly elevated on apical declivity: sides parallel, arcuately emarginate at apices; surface rather coarsely, shallowly punctate or vaguely rugose on disk, densely granulose at sides, sparsely clothed with short, recumbent, yellowish hairs, with a few long, erect, yellowish hairs intermixed.

Body beneath densely, finely punctate, densely clothed with long, erect and recumbent, yellowish hairs.

Female.-Differ's from the male in having the clypeus usually more convex at middle and more shallowly emarginate in front; the head more densely granulose, and the elytra broadly conjointly rounded at apices and usually very densely, coarsely granulose over the entire surface, the granules more or less confluent and elongate.

Length $7-13 \mathrm{~mm}$., width $1.7-3.7 \mathrm{~mm}$.

Type locality.-Of confertum, California. no definite locality; type in the Ulke Collection in the Carnegie Museum. Pittsburgh. Pa. Of incisa. California, no definite locality; type in the LeConte Collection in the Museum of Comparative Zoology. Cambridge, Mass.

Distribution.-From material examined:

Calmorxis: Oakland, May 16, 1932 (E. C. Zimmerman). Placerville (H. E. liulke). Los Gatos, Sianta ("ara ('ounty (R. E. Blackwelder. E. A. Schwarz). Blair's Ranch, Redwood Creek, Humboldt Counts, June 9, 1903 (H. s. Barber). Napa County (H. F. Wickham). San Diego (F. H. Chittendeu). Walnut Creek, June 3, 1912 (R. L. Nougaret). Santa Cruz Mountains, F'esno, April 1. (E. A. Schwar\%). Sacramento. Santa Rosa. San Francisco.

Oregox : Ashland, April 6, 1915, Phoenix (A. D. Hopkins). Eugene, June 2, 1941. 
Hosts.-Herbert (1920) stated that this species is often called the olive twig borer and usually bores in at the fork of two small branches and occasionally damages young trees seriously. The adults prune the twigs of almond, apple, apricot, avocado, birch, cherry, currant, raspberry, English elm, Eugenia myrifolia, fig, grape, live oak, olive, orange, peach, pear, prune, quince, and the strawberry tree (Arbutus unedo). The adults do not breed in all these plants, but eggs have been recorded as being laid in the dead wood of acacia, almond, apple, Oregon maple, silver maple, live oak, manzanita, tanbark oak, and rose. Herbert (1920) reported that the larvae mine in the sap and heartwood of these trees for a year and possibly more, emerging in early summer to prune a few twigs before laying eggs.

LeConte (1866) described confertus from a single female and in 1868 described Exopioides incisa from a single male, both collected at unrecorded localities in California. Horn (1878), recognizing Exopioides incisa as the male of Polycaon confertus, placed it as a synonym of the latter species.

\section{Melalgus Megalops (Fall)}

Polycaon megalops Fall, 1901, Calif. Acad. Sci., Occas. Papers 8: 25, 134, 254. Heterarthron megalops Lesne, 1938, in Junk (pub.), Coleopt. Cat., pt. 161, p. 28.

The writer has not examined any specimens of this species, and it is placed in the key entirely upon the characters given in the original description. The following is a copy of Fall's original description.

Polycaon megalops. Allied to $P$. confertus, with which it can be compared because of its 10-jointed antennae. It differs most conspicuously in the very large and prominent eyes, which are separated by three times their own diameter when viewed from the front, while in $P$. confertus they are distant fully six times their own diameter. Further differences are as follows: prothorax distinctly wider than long, not canaliculate, the transverse impression less distinct, the granulation less dense; elytra two and one-half times as long as the head and prothorax (scarcely more than twice as long in $P$. confertus), rather sparsely punctate, much as in the male of $P$. confertus, but not at all granulate towards the sides and apex; second and third tarsal joints with only a group of projecting hairs, instead of the densely matted brushes which in $P$. confertus assume the appearance of membranous lobes.

Two examples have been seen, both apparently females; one, in the writer's collection, is $5 \mathrm{~mm}$. in length, the other, in the collection of Dr. Van Dyke, is $7 \mathrm{~mm}$. long. The larger specimen barely reaches the stature of the smallest $P$. confertus, which varies in length from 7.5 to $10.5 \mathrm{~mm}$.

Specimens taken at Pomona, Los Angeles County [Calif.].

\section{Melalgus femoralis (Fabricius)}

Apate femoralis Fabricius, 1792, Entomologia Systematica, v. 1, pt. 2, p. 361.

This species, listed from Texas by Leng, ${ }^{2}$ is found only in the West Indies, and the specimens listed from Central America and Texas are femoralis Lesne (not Fabricius), which is a synonym of exesus LeConte.

\section{Melalgus parvulus (Lesne)}

Heterarthron parvulum Lesne, 1925, Encyc. Ent. (ser. B), Coleopt. 1: 29-30.

This species, listed from California by Leng and Mutchler, ${ }^{3}$ was described from Monterey, Calif., in error for Monterey, Mex., and has not been collected in the United States.

\footnotetext{
${ }^{2}$ Leng, C. W. catalogue of the coleoptera of america, North of mexico, p. 245. 1920.

${ }^{3}$ See footnote 2 (ibid. sup. 2, p. 37, 1933).
} 


\section{Genus POLYCAON Castelnau}

Polycaon Castelnau, 1836. in Silbermann's Rer. d'Ent. 4: 30; Lacordaire, 185T, Genera des Coléopt., v. 4, pp. 531-535: LeConte, 1861, Smithsn. Inst. Misc. Collect. 3 (1) : 20s; Horn, 18is, Amer. Phil. Soc. Proc. 17: 551-5.54 (part); LeConte and Horn, 18\$3, Smithsn. Inst. Misc. Collect. 507: 225-229: Lesne, 1896, Soc. Ent. de France Ann. 15: 111-114; 1938. in Junk (pub.), Coleopt. Cat., pt. 161. pp. 26-27 ; Belkin, 1940. Ent. News 51: 193.

Exops Curtis, 1839, Linn. Soc. London, Trans. 18: 203-204, pl. 15, figs. 19-20, F ; Guérin-Ménéville, 18t5, Soc. Ent. de France Ann. (ser. 2) 3: Bul. p. xrii: Agassiz, 1S46, Nomenclator Zoologicus, pt. 11, Coleoptera. p. 71 ; Blanchard, 1א.51, in Gay's Hist. de Chile, r. 5, pp. 431-436; LeConte, 15.57, Explorations and Surrey Pacific R. R., Rpt. 12 (2). pp. 19, 49.

Alloeocnemis LeConte, 1sj3, Acad. Nat. Sci. Phila. Proc. 6: 232-233; 18.j7, Explorations and Surver Pacific R. R., Rpt. 12 (2), pp. 19, 49.

Pson. Erichson $183 t$ (not Herbst 1797), Nora. Acta. Acad. Leopold, v. 16, sup. 1. p. 390 , pl. 39 , fig. 1.

Head strongly convex. not corered by prothorax, completely visible from above; clypeus large. broadly transverse, separated from front of head by an obsolete suture; labrum broadly transrerse, partially corered by clypeus, truncate or emarginate in front; mentum strongly transverse, more or less emarginate in front; maxillary and labial palpi subequal in length, densely pubescent, apical segment of each narrowly oblong, rather acutely rounded at apex; mandibles robust. asymmetrical; eyes round, globose, strongly projecting. Antenna short. 10- or 11-segmented; first segment oblong, longer than second; second to serenth or eighth segments short; last three segments forming a loose club. which is as long as or longer than the funicle, first two segments subtriangular. last segment oblong-oval. Pronotum moderately convex, truncate at base and apex, without gibbosities or dentiform tubercles, lateral margins not distinct; sides convex. Scutellum quadrate or slightly transverse. Elytra moderately convex, without longitudinal carinae on apical declivity. Legs long; anterior tibia not emarginate at base, strongly dentate on outer margin, with two spines at apices, a large arcuate one on inner margin, and a short, straight one on outer margin; tarsi 5̆-segmented, posterior pair as long as. or longer than tibiae, last segment of each shorter than preceding four segments united: second and third segments of anterior pair not expanded on apical halves. Anterior and middle coxae separated. Body elongate, moderately depressed.

Genotype.-Of Polycaon. chitiensis Castelnau. (Monobasic.) Of Exops. berani Curtis. (Monobasic, srnonym of chitiensis Castelnau.) Of Alloeocnemis, stoutii Leconte. (Monobasic.)

This genus contains but four described species, three of which are found in the United States and the other one in South America. Castelnau (1836) erected Polycaon for chitiensis Castelnau, a new species from Chile, which is a synonym of Psoa chilensis Erichson (1834). Curtis (1839) erected Exops for bevani Curtis, a new species from Chile, and placed it in the family Cleridae. Agassiz (18t6) placed Exops Curtis (1839) as a sinonym of Polycaon Castelnau (1836). Blanchard (1851) placed Psoa Erichson (not Herbst) as a synonym of Exops Curtis. LeConte (1853) erected Alloeocnemis for stoutii LeConte, a new species from California. Lacordaire (1S5̃) placed Exops Curtis and Alloeocnemis LeConte as synonyms of Polycaon Castelnau. Lesne (1896) placed Exops berani Curtis as a synonym of Polycaon chilensis Erichson. 


\section{KEY TO THE SPECIES OF POLYCAON}

1. Antenna 11-segmented; second and third tarsal segments cylindrical, not securiform $\ldots \ldots \ldots$

Antenna 10-segmented; second and third tarsal segments securiform, flattened....... granulatus Van Dyke, p. 12.

2. Third segment of antenna distinctly shorter than fourth; color

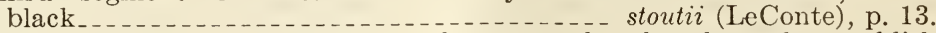

Third segment of antenna as long as the fourth; color reddish brown_........................... punctatus LeConte, p. 14.

\section{Polycaon granulatus Van Dyke}

Polycaon gramulatus Van Dyke, 1923, Brooklyn Ent. Soc. Bul. 1S: 43-45; Lesne, 1925, Encyc. Ent. (ser. B), Coleopt. 1: 30-31; 1938, in Junk (pub.), Coleopt. Cat., pt. 161, p. 27.

Male.-Elongate, subcylindrical. opaque, black, cxcept antennae, tarsal claws, and lateral margins of elytra, which are reddish brown.

Head including eyes distinctly wider than pronotum, convex in front, finely, densely granulose, sparsely clothed with short, erect hairs, with a few long, erect. black hairs intermixed; clypcus broadly depressed in front at middle, truncate in front: eyes very large, clobose, strongly projecting, each one-third as wide as width of head between them. Antenna 10-segmented, clothed with a few long, erect hairs; third segment subequal in length to fourth; last three segments forming a loose club, together longer than rest of segments united.

Pronotum subequal in length and width, widest near apical fourth, broadly, transversely depressed behind anterior margin, narrowly, transversely flattened along base; sides broadly rounded anteriorly, more strongly converging posteriorly, sinuate near base; surface densely, finely granulose, rather densely clothed with long, erect, black hairs, with a few shorter, recumbent hairs on median part.

Elytra much wider than pronotum, arcuately declivous toward apices; sides nearly parallel, separately incised and bidentate at apices; disk strongly convex; surface densely, finely granulose, rather densely clothed with short, recumbent, black hair's, with a few long, erect, black hairs intermixed.

Body beneath finely, densely granulose or rugose, rather densely clothed with moderately long, recumbent and semierect, whitish hairs, with a few long, erect hairs intermixed. Anterior tibia robust, expanded toward apex, dentate on exterior margin, without basal excavation; second and third tarsal segments elongate, securiform.

Female.-Differs from the male in having the tips of the elytra conjointly rounded.

Length 8-10 mm., width 2.5-3.5 mm.

Type locality.-Carmel, Monterey County, Calif.

Type.-In the Van Dyke Collection in the California Academy of Sciences.

Van Dyke described this species from three males and one female, all collected at the type locality on March 8 and September 3-19, 1916, by L. S. Slevin.

Through the kindness of E. Gorton Linsley the writer was able to study two specimens of the type series. This species seems to connect Polycaon and Melalgus, having characters common to both genera, but the writer prefers to retain both genera until more specimens are available for study. $P$. granulatus agrees with Polycaon in having 
the anterior tibia not excavated or arcuate at the base, the sides of the pronotum convex, and the elytra without carinae or tubercles on the apical declivity, and with Melalgus in having the body cylindrical, the second and third tarsal segments securiform, and the elytra of the male incised and bidentate at the apex.

\section{Polycaon stoutil (LeConte)}

Allococnemis stoutii LeConte, 1853, Acad. Nat. Sci. Phila. Proc. 6: 233.

Fxops stoutii LeConte, 1857, Explorations and Survey Pacific R. R., Rpt. 12 (2), p. 19.

Polycuon stoutii Horn, 1878, Amer. Phil. Soc. Proc. 17: 552-553; Lesne, 1896, Soc. Ent. de France Ann. 65: 112, 113, pl. 9, fig. 16; Fall, 1901, Calif. Acad. Sci. Occas. Papers s: 25, 134; Herbert, 1920, Jour. Econ. Ent. 13 : 361; Tanner, 1927, Amer. Ent. Soc. Trans. 53: 14, 31, figs. 147, 14s (female genitalia) ; Böving and Craighead, 1931, Ent. Amer. (n. ser.) 11: 62, pl. 102, figs. B-E (larrae) ; Lesne, 1938, in Junk (pub.), Coleopt. Cat., pt. 161, p. 27 ; Anderson, 1939, Wash. Acad. Sci. Jour. 29 : 390, figs. 12, 13, 15, 16 (larrae).

Exops oxicollis LeConte, 1857, Explorations and Survey Pacific R. R., Rpt. 12 (2), pp. 19, 49, pl. 1, fig. 19; Horn, 1878, Amer. Phil. Soc. Proc. 17 : 552.

Male.-Elongate, moderately depressed, uniformly black, antennae, palpi, and sometimes tarsi reddish brown.

Head in front subequal in width to pronotum at apical fourth. broadly, transversel ${ }_{y}$ depressed behind eyes, shining, coarsely, densely granulose, the granules round and flat. sparsely clothed with rather short. inconspicuous, recumbent liairs, with a few long. erect hairs intermixed; clypeus broadly concave at middle, deeply, arcuately emarginate in front. Antenna 11-segmented. with a fer semierect hairs: third segment distinctly shorter than fourth: funicle longer than club.

Pronotum widest near apical fourth. with a narrow median line. and a large triangular flattened, median space along anterior margin : sides broadly rounded anteriorly, obliquely narrowed posteriorly; surface moderately shining, finely, densely punctate at middle, finely, densely granulose at sides, sparsely clothed with short, inconspicuous, recumbent hairs. with a few long, erect hairs intermixed.

Elytra at base slightly wider than pronotum at apical fourth. arcuately declivous posteriorly: sides paraflel, broadly conjointly rounded at apices; surface moderately shining, finely, densely punctate, finely reticulate, sparsely clothed with very short, inconspicuous, recumbent hairs.

Body beneath rather densely clothed with long. fine, erect hairs, which are shorter and more recumbent on abdomen: prosternum coarsely granulose or rugose; abdomen finely, densely punctate.

Female.-Dillers from the male in having the head narrower than pronotum. subopaque, more finely. confluently granulose, and not depressed behind the eyes, the clypeus obsoletely concave at middle and feebly emarginate in front. the pronotum subopaque. more finely. densely granulose and more densely punctate at middle, and the elytra subopaque and finely granulose at base.

Length 10-2t mm., width $3-6.5 \mathrm{~mm}$.

Type locality.-Of stoutii and ovicollis. San Francisco, Calif.; types in the LeConte Collection in the Museum of Comparative Zoology, Cambridge, Mass. 


\section{Distribution.-From material examined:}

Arizona : Miller's Canyon, Huachuca Mountains, October 6, 1909 (H. A. Kaeber). California: Various localities throughout the State.

OKlahoma: Oklahoma City, March 16, 1942, boring in a table leg. OREgon: Rogue River, September 17, 1913, (W. D. Edmonston).

Tennessee: Memphis, June 20, 1933, boring in a redwood dresser (G. C. Brown). Texas: Ysleta, June 30, 1933, boring in a mahogany table (C. A. King).

Uтан: Ogden; Eureka, July 26 (Tom Spalding).

Wyoming: Evarston, June 15, 1885.

Hosts.-It has been reared from prune and hickory, and has been reported as pruning twigs. Herbert (1920) reported it as breeding in California laurel, coast live oak, madrone, and manzanita, and attacking the branches of almond and Eucalyptus globulus.

LeConte (1853) described stoutii as the genotype of his new genus Alloeocnemis and he (1857) described ovicollis, placing it in the genus Exops, both species being from San Francisco, Calif. Horn (1878) placed ovicollis in synonymy as the female of Polycaon stoutii.

\section{Polycaon punctatus LeConte}

Polycaon punctatus LeConte, 1866. Smithsn. Inst. Misc. Collect. 167: 102-103; Horn, 1878, Amer. Phil. Soc. Proc. 17 : 552, 553 ; Lesne, 1896, Soc. Ent. de France Ann. 65: 112, 114; 1938, in Junk (pub.), Coleopt. Cat., pt. 161, p. 27 ; Belkin, 1940, Ent. News 51: 193.

Polycaon pubescens LeConte, 1866, .Smithsn. Inst. Misc. Collect. 167 : 102 ; Horn, 1878, Amer. Phil. Soc. Proc. 17 : 552, 553.

F emale.-Elongate, moderately depressed and shining, uniformly pale reddish brown.

Head in front slightly narrower than pronotum at apical fourth, convex behind eyes, finely, rather densely, uniformly granulose, sparsely clothed with long, erect and recumbent, blackish hairs; clypeus broadly, obsoletely depressed at middle, rather shallowly, arcuately emarginate in front. Antenna 11-segmented, with a few long. erect hairs; third segment subequal in length to fourth ; funicle slightly shorter than club.

Pronotum widest at apical fourth, broadly, feebly, transversely depressed along anterior margin; sides broadly rounded anteriorly, obliquely narrowed posteriorly ; surface coarsely, confluently punctate at middle, rather densely granulose at sides, sparsely clothed with short, recumbent, brownish hairs, with a few long, erect, blackish hairs intermixed.

Elytra at base distinctly wider than pronotum, arcuately declivous posteriorly ; sides parallel, broadly conjointly rounded at apices; surface finely, sparsely punctuate, sparsely clothed with short, inconspicuous, recumbent, blackish hairs.

Body beneath sparsely clothed with long, erect hairs, which are shorter and more recumbent on abdomen; prosternum coarsely granulose or rugose; abdomen finely, densely punctuate.

Length $10 \mathrm{~mm}$, width $2.6 \mathrm{~mm}$.

Type locality.-Of punctatus, Lower California; type in the Ulke Collection in the Carnegie Museum, Pittsburgh, Pa. Of pubescens, Cape San Lucas, Lower California; type in the LeConte Collection in the Museum of Comparative Zoology, Cambridge, Mass.

Distribution.-Lower California. Only a single female has been examined, which is in the Hubbard and Schwarz Collection, in the United States National Museum, and simply labeled "Cal." 
LeConte (1866) described both punctatus and pubescens from Lower California, and Horn (1878) placed pubescens in synonymy as the female of punctatus.

\section{Tribe Psoini}

Psoini LeConte, 1861, Smithsn, Inst. Misc. Collect. 3 (1) : 207, $20 \mathrm{~S}$ (part) ; Kiesenwetter, 1877, in Erichson, Naturgesch. Insect. Deut. Coleopt., v. 5, pt. 1, pp. 7-11; Schilsky, 1899, in Küster and Kraatz, Käfer Europas 36: p. ss ; LeConte and Horn, 1883, Smithsu. Inst. Misc. Collect. 507 : 227, 228-229 (part) ; Lesne, 1901, Abeille 30:73, 74-77; 1921, Assoc. Franc. pour l'Aranc. des Sci., Cong. de Strasbourg (1920), p. 2S8; 1938, in Junk (pub.), Coleopt. Cat., pt. 161, pp. 29-31.

Psoina Jakobson, 1913, Käfer Russland, pt. 10, pp. 801-802.

Psoinae Lesne, 1896, Soc. Ent. de France Ann. 65: 96, 97-110 ; Anderson, 1939, Wash. Acad. Sci. Jour. 29:38s-390 (larrae) (part).

Psoidae Böving and Craighead, 1931, Ent. Amer. (n. ser.) 11: 62, pl. 102, figs. A-E (larrae) (part).

This tribe contains five genera, of which Psoa is the only one found in the United States.

\section{Genus PSOA Herbst}

Psoı Herbst, 1797, Natursystem Insekten, Käfer, v. т, pp. 214 -215; Redtenbacher, 1845, Gattungen Deut. Kaefer Fauna, p. 94; Guérin-Ménéville 1845, Soc. Ent. de France (ser. 2) 3 : Bul. p. xvii ; Redtenbacher, 1847-1849, Fauna Austriaca, Die Käfer, pp. 35, 355 ; Blanchard, 1851, in Gay, Hist. Chile, v. 5, pp. 436-437; Lacordaire, 1857, Genera des Coleopt., r. 4, pp. 534, 536-537; Redtenbacher, 1858, Fauna Austriaca, Die Käfer, ed. 2, pp. CI, 570-571; Jacquelin-Duval, 1859-1863, Genera Coléopt. Europe, r. 3, pp. 232-233, pl. 57, fig. 282a ; Kiesenwetter, 18т7, in Erichson, Naturgesch. Ihsect. Deut. Coleopt., v. 5, pt. 1, pp. 7-9, fig. : LeConte and Horn, 1853, Smithsn. Inst. Misc. Collect. 507 : 228; Seidlitz, 1889, Fauna Baltica, Kaefer, ed. 2, p. 116; 18s9, Fauna Transsylvanica, Kaefer, pp. 116, 529; Zoufal, 1S94, Wien. Ent. Ztg. 13 : 33-34; Lesne, 1896, Soc. Ent. de France Ann. 65: 97, 98-104; Schilsky, 1899, in Küster and Kraatz, Käfer Europas, v. 36, pp. ss, ww ; Lesne, 1901, Abeille 30: 74-76 ; Reitter, 1911, Fauna Germanica, r. 3, p. 300 ; Lesne, 1912, Paris Mus. d'Hist. Nat. Bul. 1S: 404-409, figs.; Jakobson, 1913, Käfer Russland, v. 10, pp. 801, 802; Lesne, 1913, Paris Mus. d'Hist. Nat. Bul. 19: 271-275, figs. 1-3; 1938, in Junk (pub.), Coleopt. Cat., pt. 161, pp. 29-30.

Acrepis LeConte, 1852, N. Y. Lyc. Nat. Hist. Ann. 5: 213; 1861, Smithsn. Inst. Misc. Collect. 3 (1) : 208; Horn, 1878, Amer. Phil. Soc. Proc. 17 : 554: 1886, Amer. Ent. Soc. Proc. 13: xr-xri, figs. 1-2; Lesne, 1896, Soc. Ent. de France Ann. 65 : 99 ; 1912, Paris Mus. d'Hist. Nat. Bul. 18: 408; 1913, Bul. 19 : 271.

Head slightly flattened, not covered by prothorax, completely visible from above; clypeus not distinctly separated from front of head in American species, vaguely, broadly rounded or subtruncate in front; labrum small, indistinct, nearly covered by clypeus; mentum small, transverse, subtruncate in front; maxillary palpi longer than labial palpi, apical segment of each palpus subequal in length to preceding segment, but broader, oblong, and truncate at apex; labial palpi short, apical segment of each palpus as long as preceding two segments united, subtruncate at apex; mandibles short, robust, symmetrical; eyes round or oblong, globose, strongly projecting. Antenna longer than head, 10-segmented; first segment robust, obconical, longer than second; second small, oval; third to seventh short. subequal in length; last three segments forming a loose club, the segments subglobose, eighth subtriangular, ninth and tenth oval. Pronotum moderately convex, vaguely emarginate at apex, truncate at base. without gibbosities or dentiform tubercles, and without distinct lateral margins; sides obliquely deflexed, flattened. Scutellum small, sul)- 
triangular. Elytra elongate, convex or subdepressed, parallel or slightly expanded posteriorly, without longitudinal carinae on apical declivity. Legs long and slender; anterior tibia not emarginate at base, coarsely dentate on outer margin, without a large arcuate spine at apex but with three spines at apex, two short straight ones on inner margin, and a short, obtuse one on outer marqin; tarsi 5 -segmented; posterior pair as long as or longer than tibiae. first segment not distinct; last segment of each shorter than preceding four segments united; second and third segments of anterior pair slender, not or only slightly expanded on apical halves. Anterior conae very narrowly separated by a short prosternal process: middle coxae very narrowly separated. Bodr elongate, cylindrical.

Genotype.-Of Psoa, viennensis Herbst. (Monobasic.) Of Acrepis, maculata Le Conte. (Monobasic.)

This genus contains four described species, two from Europe and two from the United States.

Herbst (1797) erected Psoa for his new species, viennensis, from Austria. LeConte (1852) erected the genus Acrepis for a single specimen he collected at San Francisco, Calif., which he named maculata. In 1861 LeConte stated that this type was lost at sea, while on the way to Europe for examination by Lacordaire, and that he was unable to determine the differences between Acrepis and Psoa, but it was quite possible that Acrepis should be united either with Psoa or Exopioides. Horn (1878) stated that on the basis of the material before him Acrepis should be suppressed as a synonym of Psoa.

\section{KEY TO THE SPECIES OF PSOA}

Pronotum wider than long, usually widest at middle, subopaque, and densely punctate; sides broadly rounded _......... maculata (LeConte), p. 16.

Pronotum not wider than long, widest along apical half, strongly shining, and rather sparsely punctate; sides usually more strongly converging posteriorly _............................ quadrisignata (Horn), p. 17.

\section{Psoa maculata (LeConte)}

Acrepis maculata LeConte, 1852, N. Y. Lyc. Nat. Hist. Ann. $5: 213$.

Psoa maculata Horn, 1878, Amer. Phil. Soc. Proc. 17: 554, 555; 1886, Amer. Ent. Soc. Proc. 13: pp. xv-xvi, fig. 1; Coquillett, 1892, Insect Life 4: 261; Lesne, 1896, Soc. Ent. de France Ann. 65: 99, 100-101, fig. 1A; Lintner, 1896, N. Y. State Mus. Rpt. 49 (1895), p. 268: Fall, 1901, Calif. Acad. Sci. Occas. Papers, No. S: 25, 134; Lesne. 1912, Paris Mus. d'Hist. Nat. Bul. 18: 404-409; 1913, ibid. 19: 271-275; 1938 in Junk (pub.), Coleopt. Cat.. pt. 161, 1. 30 ; Anderson, 1939, Wash. Acad. Sci. Jour. 29 : 390, figs. 14, 17 (larvae).

Psoa (Acrepis) cleroides Lesne, 1913, Paris Mus. d'Hist. Nat. Bul. 19: 273-275, figs. 2-3; 1938, in Junk (pub.), Coleopt. Cat., pt. 161, p. 29 ; Belkin, 1940, Ent. News $51: 193$.

Male.-Elongate, cylindrical: head and pronotum black, with a distinct purplish or greenish tinge; elytra bluish or greenish black, with variable shaped yellow markings, rarely without yellowish markings: beneath bluish, purplish, or greenish black, the posterior margins of abdominal sternites yellowish, and the antennae, tarsi, and palpi reddish brown.

Head in front narrower than pronotum, moderately flattened, coarsely, uniformly, confluently punctuate, rather densely clothed with long and short, fine, erect hairs.

Pronotum slightly wider than long, widest near middle, moderately convex; sides broadly, arcuately rounded, sometimes more strongly 
converging posteriorly; surface coarsely, uniformly, densely punctate, rather densely clothed with long and short, fine, erect hairs.

Elytra at base slightly wider than pronotum, arcuately declive near apices; sides parallel or slightly expanded posteriorly. separats!y. broadly rounded at apices: surfaces finely. densely, uniformly j'm tate. rather densely clothed with rather short, erect. whitish hairs.

Body beneath finely, densely punctate or reticulate. densely clotl or with long. semierect. Whitish hairs: last visible abdominal sternite broadly. deeply, arcuately emarginate at apex: second and third serrments of anterior tarsi slightly expanded, and densely pubsscint beneath.

Female.-Differs from the male in having the last visible abdrm n:? sternite rounded at the apex, the second and third segments of anter. ${ }^{\circ}$ tarsi not expanded, or conspicuously pubescent beneath. and $u=11 ; 11 \mathrm{y}$ with all the abdominal sternites miformly reddish vellow.

Length 6-11 mm.. width 2-3.5 mm.

Type locality.-Of maculata. San Francisco. Calif.: trpe lost. Of cleroides. San Diego, Calif.: type was in the Deutsches Entomologische Museum in Berlin.

Distribution.-Gouthern California. I good serie- has been examined from Los Angeles Count y. all collected by D. W. Coquillett. A!so recorded by Coquillett (1592) from Santa Barbara and br Horn (15.52) from San Francisco. Specimens of cleroides examined that were collected by Coquillett in Los Angeles County and by J. C. Bridwell at Berkeley.

Hosts.-Coquillett (1S92) recorded the larvae and pupae in drr apple limbs during October, also in dry prunings of graperines and rotten stems of Audibertia polystarhya.

This species was described by LeConte (1852) from a single specimen collected br himself at San Francisco. Calif.. for which he erected his new genus Acrepis. Tnfortunately this specimen was lost at sea. Horn (1Ss6) redescribed maculata and figured the different elrtral markings. Lesne (1913) described cleroides from a single male in the Deutsches Entomologische museum in Berlin. collected at San Diego. Calif. This form is greenish black, the abdomen entirely reddish, and each elytron with two small reddish spots, one basal and one near apex. This form seems to be intermediate between maculata and quadrisignata, having the wide pronotum of maculata and the elvtral markings of quadrisignata. Having more of the structural characters of mrevlata, it can be considered at most only an aberration of that species.

\section{PSOA QUADRISIGNATA (Horn)}

Acrepis quadrisignata Horn, 1S68, Amer. Ent. Soc. Trans. 2 : 135-136.

Psoa quadrisignata Holn, 1578, Amer. Phil. Soc. Proc. 17: 555; 18-6. Amer. Fnt. Soc. Proc. 13: xri, fig. 2; Blaisdell, 1892, Insect Life 5: 34; Lesme, 1s96, sо॰. Ent. de France Ann. 65: 99-100, fig. 1B; Fall, 1901, Calif. Acad. Sci. Oc:as. Papers. No. S: 25, 134: Lesne, 1912. Paris Mus. d’Hist. Nat. Bul. 1\: 404-409. figs.: 1913. ibid. 19: 271-275, fig. 1: 1938, in Junk (pub.), Coleopt. Cat., nt. 1 (i1. p. 30 : Belkin, 1940, Ent. News 51: 193.

Ab. Psoa (Acrepis) seriguttata Lesne, 1906. Soc. Ent. de France Ann. 7. : 393-394.

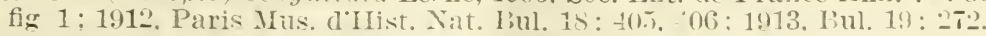

Male.-Elongate, cylindrical: head and pronotum black. with a distinct purplish and greenish tinge; elytra varying from reddish vellow with a few greenish cr purplish-black spots to greenish or prirplish $842409-50-2$ 
black with a few reddish-yellow spots; body beneath greenish or purplish black, the posterior margin of abdominal sternites yellowish, and palpi and tarsi sometimes reddish brown.

Head slightly narrower than pronotum, moderately flattened, coarsely, densely, uniformly punctate, densely clothed with long and short, fine, erect hairs.

Pronotum quadrate, widest along apical half or at middle, moderately convex; sides broadly, arcuately rounded or parallel anteriorly, more strongly converging posteriorly; surface shining, coarsely, uniformly, rather sparsely punctate, rather densely clothed with long and short, fine, erect hairs.

Elytra slightly wider than pronotum, arcuately declivous near apices; sides parallel or slightly expanded posteriorly, separately, broadly rounded at apex; surface densely, finely, rugosely punctate, rather densely clothed with rather short, erect, whitish hairs.

Body beneath finely, densely, rugosely punctate, densely clothed with long, semierect, whitish hairs; last visible adbominal sternite broadly, deeply, arcuately emarginate at apex; second and third segments of anterior tarsi slightly expanded, and densely pubescent beneath.

F emale.-Differs from the male in having the last visible abdominal sternite broadly rounded at the apex, the second and third segments of anterior tarsi not expanded, or conspicuously pubescent beneath, and usually with all the abdominal sternites uniformly reddish yellow.

Length 4.6-9 mm., width 1.2-2.5 mm.

Type locality.-Of quadrisignata, near San Francisco, Calif.; type in the Ulke Collection in the Carnegie Museum, at Pittsburgh, $\mathrm{Pa}$. Of sexguttata, Mexico; type in the collection of René Oberthür.

Distribution.-From material examined:

California : Los Angeles County (D. W. Coquillett). Los Gatos (Hubbard and Schwarz). Mendocino County, May 1, 1919 (E. R. Leach). Oakland, March 21, 1931 (E. C. Zimmerman). Blair's Ranch, Redwood Creek, Humboldt County, June 19, 1903 (H. S. Barber).

Oregor: Hood River, May 19 (Hubbard and Schwarz). Corrallis, May 7, 1931. Washington: Moxee, April 29, 1943 (J. C. Dodge). Yakima, April 20-24, 1943

(E. J. Newcomer).

It has been recorded by Horn (1878) from Mariposa County, by Blaisdell (1892) from San Diego County, and by Lesne $(1896,1913)$ from Sierra Nevada and Napa, Calif.

Host.-Grape canes. E. J. Newcomer reported that during the early part of 1943 this species seriously damaged 75 percent of the 2 -year-old grapes in various vineyards in Washington, killing back almost to the ground the canes trained the previous year to be used as the main leaders.

This species was described by Horn (1868) from a specimen collected near San Francisco, Calif. Horn (1878) transferred the species to Psoa and described a number of varieties based principally upon the elytral markings without giving names to these varieties. In 1886 he figured the varieties.

Lesne (1906) described sexguttata from a single female in the René Oberthür Collection, originally labeled Malasia, but this locality label had been changed to Mexico. It seems that the locality is uncertain, and since no Psoa have been recorded from Mexico this specimen may have been collected in California. This form has the elytra 
reddish yellow, each elytron with three subrounded greenish-black spots, and Lesne (1938) placed it as an aberration of quadrisignata.

The markings on the elytra of this species are quite variable and do not seem even to represent stable aberrations or varieties. In a large series of specimens collected in Los Angeles County by Coquillett on the same date, all four named forms are represented (maculata, quadrisignata, cleroides, and sexguttata).

It is very difficult to give any distinct characters for separating maculata and quadrisignata on account of the variable elytral markings. In maculata the elytral markings have a tendency to become vittate, whereas in quadrisignata the dark ground color gradually becomes smaller, leaving the elytra simply reddish yellow and more or less spotted with blue. In quadrisignata the thorax is more nearly ovate and more shining and convex than in maculata. resembling some species of Polycaon. whereas in maculata it is more depressed and resembles some of the Cleridae.

\section{Subfamily ENDECATOMINAE}

Endecatomini LeConte, 1861, Smithsn. Inst. Misc. Collect. 3 (1) : 207 ; Horn, 1878, Amer. Phil. Soc. Proc. 17: 540; LeConte and Horn, 1883, Smithsn. Inst. Misc. Collect. 507 : 227.

Hendecatomidae Kiesenwetter, 1877, in Erichson, Naturgesch. Insect. Deut., Coleopt., v. 5, pt. 1, pp. 7, 23-25; Lesne, 1921, Assoc. Franc. pour l'Aranc. des Sci., Cong. de Strasbourg (1920), p. 287 ; 1934, Soc. Ent. de France Bul. $39: 174$; 1935, Paris Mus. d'Hist. Nat. Arch. (vol. du Tricent.) (ser. 6) $12: 432-433$.

Hendecatominae Lesne, 1938, in Junk (pub.), Coleopt. Cat., pt. 161, pp. 4-5.

This subfamily is represented by the genus Endecatomus Mellié. Most early writers associated this subfamily or tribe with the Cisidae, but Jacquelin-Duval (1859-1863) placed it in the family Lyctidae. LeConte (1861) erected the tribe Endecatomini for Endecatomus rugosus (Randall) and placed it in the family Bostrichidae, stating that this tribe is a connecting link between the Anobiidae and Bostrichidae. Lesne $(1921,1934,1935)$ placed it as a subfamily of the Bostrichidae. Forbes ${ }^{4}$ stated that according to the wing folding pattern it is a normal bostrichid and does not show any connections with the Cisidae. Lesne (1935) stated that according to the sensory pits on the antennae, buccal pieces, wings, tarsi, abdominal stigmae, and male genitalia, Endecatomus is very distinctly connected to the Bostrichidae.

\section{Genus ENDECATOMUS Mellie}

Endecatomus Mellié, 1847, Rev. Zool. 10: 108-109; 1848, Soc. Ent. de France Ann. (ser. 2) 6: 206-209, 213-218, pl. 9, figs. 1-8; Redtenbacher, 185s, Fauna Austriaca, Käfer, ed. 2, pp. Cl, 571; 1874, ed. 3, pt. 2, pp. 67-68.

Hendecatomus Bach, 1852, Käferf. v. 2, pt. 3, pp. 100, 10s; Schaum, 1852, Cat. Coleopt. Europae, ed. 4, p. 55 ; Dohrn, 185., Cat. Coleopt. Europae, ed. 5, p. 56 ; 1856, ed. 6, p. 53 ; Lacordaire, 1857, Genera des Coléopt., v. 4, pp. 547, 549; Jacquelin-Dural, 185̄9-1863; Genera Goléopt. Europe, v. 3, 1. 235; ; Gemminger and Harold, 1869, Cat. Coleopt., v. 6, p. 1795: Stein and Weise, 1877, Cat. Coleopt. Europae, p. 110; Kiesenwetter, 18 7 , in Erichson, Naturgesch. Insect. Deut., Coleont., v. 5, pt. 1, pp. 23-25, fig.; Horn, 187s, Amer. Phil. Soc. Proc. 17 : 540-541; Ireyden, Reitter, and Weise, 1883, Cat. Coleopt. Europale, p. 125: LeConte and Horn, 1883, Smithsn. Inst. Misc. Collect. 507 : 227; Marchal, 1s5s, Feuille Jeunes Nat. 18 (208) : 50 ; Seidlitz, 18s9, Fauna Baltica, Kïfer, ed. 2.

\footnotetext{
${ }^{4}$ Forbes, W. T. M. Jour. 34: 99 (fig. 75 ).

WING FOLDING PATTERNS OF COLEOPTERA. 1926.
} 
p. 117 ; 1889, Fauna Transylvanica, Käfer, pp. 117, 548; Zoufal, 1894, Wien.

Ent. Ztg. 13: 35, 42; Heyden, Reitter, and Weise, 1906, Cat. Coleopt. Europae, p. 349 ; Reitter, 1911, Fauna Germanica, v. 3, p. 98 ; Jakobsen, 1913, Käfer Russland, v. 2, pp. 952-953; Lesne, 1934, Soc. Ent. de France Bul. 39: 174-175; 1935, Assoc. Nat. Loing, Bul. 18: 54, figs. 1-2 (publication not seen) ; 1935, Paris Mus. d'Hist. Nat. Arch. (vol. du Tricent.) (ser. 6) 12:427-433; 1938, in Junk (pub.), Coleopt. Cat., pt. 161, p. 5.

Dictyalotus Redtenbacher, 1847, Fauna Austriaca, Käfer, p. 348.

The foregoing bibliography given for the genus is not complete, as only the most important articles are cited, especially those dealing with the American species.

Head slightly convex, partially covered by the prothorax; clypeus strongly transverse, separated from front of head by a distinct transverse depression; mentum transverse, triangular. deeply, broadly cmarginate in front; maxillary palpi 4-segmented, apical segments oblong, acute at apices; labial palpi 3-segmented, slightly shorter than maxillary palpi, apical segments oblong, acute at apices; mandibles robust, arcuate, bidentate on inner margins; eyes round, slightly projecting. Antenna short, 11-segmented; first segment elongate, expanded toward apex; second broadly oblong; third to fifth narrow, slightly elongate; sixth to eighth round, the eighth sometimes transverse; ninth to eleventh much broader. forming a distinct club, the ninth subtriangular or subrounded, tenth transverse, and eleventh round. Prothorax transverse, sides rounded and distinctly margined. Scutellum small, quadrate. Elytra strongly convex, rounded posteriorly. Legs short, subequal in length; tibiae slender or slightly expanded toward apices, the anterior pair with a large arcuate spine on inner margin at apices and a smaller spine on outer margins; tarsi 5 -segmented; last segment of each as long as the preceding four segments united. Anterior coxae prominent, contiguous. Middle coxae narrowly separated. Body cylindrical.

Genotype.-Of Endecatomus, Anobium reticulatum Herbst. (Monobasic.) Of Dictyalotus, Anobium reticulatus Herbst.

\section{(Monobasic.)}

Endecatomus is a small genus comprised at present of four described species-reticulatus Herbst fomnd in Europe, dorsalis Mellié found in Texas and the central part of the United States, rugosus (Randall) restricted to the eastern half of the United States and Canada, and lanatus Lesne found in the Amour region of Asia.

Mellié (18ti) divided the genus $C$ is into six genera, creating Endecatomus for a species from central Europe which Herbst had described in 17.93 under the name of Anobium reticulatum. During the same year Redtenbacher (1847) erected the genus Dictyalotus for Anobium reticulatus Herbst, placing it in the "Anobii". The following year Mellié (18t8) described the genus in great detail, figuring the adult including various parts of the insect, with the following remarks: "I erected the genus Endecatomus in 1817 for Anobium reticulatum Herbst during March, and at the end of 1847 . Redtenbacher erected Dictyalotus for the same species, placing it in the Anobiidae after the genera Anobium and Ochina."

Schaum (1852) emended Endecatomus to Hendecatomus (this may have been emended in a previous edition, which is not available) and placed it in the family Cioidae. The original spelling has been used by the American workers and is preferred by the present writer, but most European workers use the emended name. 


\section{KEY TO THE SPECIES OF ENDECATOMUS}

Lateral margins of elytra with a row of straight, short, stiff, erect hairs; arcuate hairs on disk of elytra short, recumbent, and without a distinct spur; seventh antennal segment transverse_....... dorsalis Mellié, p. 21.

Lateral margins of elytra with a row of long, arcuate hairs; arcuate hairs on disk of elytra long, erect, with a distinct spur; seventh antennal segment round or slightly elongate_.............. rugosus (Randall), p. 21.

\section{Endecatomus dorsalis Mellié}

Endecatomus dorsalis Mellié, 1848, Soc. Ent. de France Ann. (ser. 2) 6: 218: Melsheimer, 1853, Cat. Coleopt. U. S., p. 85; Gemminger and Harold, 1s69, Cat. Coleopt., v. 6, p. 1795 ; Horn, 1878, Amer. Phil. Soc. Proc. 17 : 540 ; Lesne, 1935, Soc. Ent. de France Bul. 40 : 198 ; 1938, in Junk (pub.), Coleopt. Cat., pt. 161, p. 5.

Elongate (more than twice as long as wide), uniformly dark brown, reddish brown or yellowish brown, with the palpi and antennal club slightly paler.

Head transversely depressed behind clypeus, coarsely, confluently gramulose or tuberculose, rather densely clothed with short, semierect, yellowish hair; clypeus broadly truncate or feebly, arcuately emarginate in front. Antenna short, extending to base of elytra. rather densely clother with short, semierect hairs; eighth segment slightly transverse.

Pronotum strongly, irregularly convex, slightly wider at base than at apex, widest behind middle; sides slightly flattened, strongly margined, oblique anteriorly, and broadly rounded posteriorly, the margins coarsely crenulate; anterior margin strongly loled at middle; base broarlly subtruncate: surface feebly. longitudinally depressed at middle. densely uniformly granulose or tuberculate, sparsely, irregularly clothed with semierect, arcuate, yellowish hairs, which are denser and straight along lateral margins.

Elytra at base subequal in width to pronotum behind middle: sides parailel, conjointly broadly rounder at apices; disk strongly convex; surface sparsely, coarsely, irregularly granulose, sparsely, irregularly clothed with short, recumbent, arcuate, yellowish hairs on disk intermixed with short, stiff, erect hairs toward apices, the arcuate hairs without a distinct spur, and with a row of straight, stiff, erect hairs along lateral margins.

Body beneath finely, densely, uniformly granulose. sparsely clothed with short, recumbent, vellowish hairs.

Length 4.ॅ-5 mm., width $2 \mathrm{~mm}$.

Type locality.-Texas; location of type not known to writer.

Distribution.-From material examined:

Texas: No locality, Linell Collection. Dallas (Hubbard and Schwarz).

Missouri : Cadet.

IllivoIS: Southern part, May 16, 1891 (H. Soltau).

Host.-Not recorded, but probably is some of the woody fungi. Endecatomus dorsalis is usually more elongate than rugos?i.

ENDECATOMUs RUgosus (Randall)

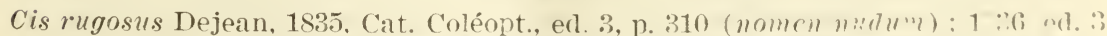

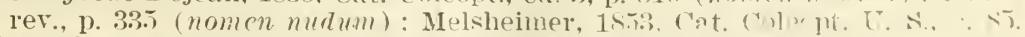

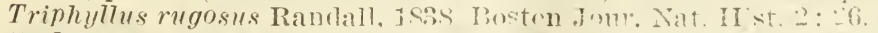

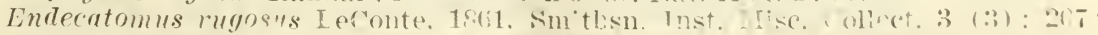
Austin, 1875. Boston Soc. Nat. Ilist. Iroc. 17: 384 : Iirn. 157s, Imm. I'hil.

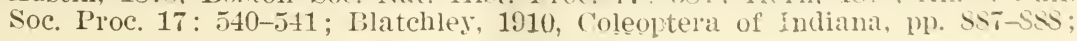


Forbes, 1926, N. Y. Ent. Soc. Jour. 34: 99, fig. 75 ; Leonard, 1928, N. Y. (Cornell) Agr. Expt. Sta. Mem. 101: 415 ; Brimley, 1938, Insects of North Carolina, p. 197. Hendecatomus rugosus Gemminger and Harold, 1869, Cat. Coleopt., v. 6, p. 1795; Reitter, 1911, Fauna Germanica, v. 3, p. 98; Lesne, 1934, Soc. Ent. de France Bul. 39 : 174-175; 1935, ibid. 40 : 197-199, fig. R ; 1938, in Junk (pub.), Coleopt. Cat., pt. 161, p. 5.

Endecatomus reticulatus (not Herbst) Melsheimer, 1853, Cat. Coleopt. U. S., p. 85 ; Le Conte, 1854, Acad. Nat. Sci. Phila. Proc. 7 : 218 ; Jacquelin-Duval, 18591863, Genera Coléopt. Europe, v. 3, pp. 168, 235, pl. 57, fig. 284; Horn, 1878, Amer. Phil. Soc. Proc. 17: 540-541 (part) ; Blatchley, 1910, Coleoptera of Indiana, p. 887.

Hendecatomus reticulatus Zoufal, 1894, Wien. Ent. Ztg. 13 : 42 (part) ; Schilsky, 1900, in Küster and Kraatz, Käfer Europas, v. 37, Nos. 37, 37a (part) ; Leonard, 1928, N. Y. (Cornell) Agr. Expt. Sta. Mem. 101: 415; Lesne, 1934, Soc. Ent. de France Bul. 39 : 174-175 (part) ; 1935, ibid. 40: 197-199, fig. $\mathrm{R}^{\prime}$ (part) ; 1938, in Junk (pub.), Coleopt. Cat., pt. 161, p. 5 (part).

Elongate (twice as long as wide), uniformly dark brown to reddish brown, strongly shining (when not covered with foreign matter), the palpi and antennal club slightly paler.

Head transversely depressed behind clypeus, coarsely, confluently granulose or tuberculose, rather densely clothed with short, semierect, yellowish hairs; clypeus broadly truncate or feebly, arcuately emarginate in front. Antenna extending to base of elytra, rather densely clothed with short, semierect, yellowish hairs; eighth segment rounded.

Pronotum strongly, irregularly convex, slightly wider at base than at apex, widest behind middle; sides slightly flattened, strongly margined, oblique anteriorly, and broadly rounded posteriorly, the margins coarsely uniformly crenulate; anterior margin strongly lobed at middle; base broadly subtruncate; surface feebly, longitudinally depressed at middle, densely, uniformly granulose, the granules elevated and distinctly separated, sparsely, irregularly clothed with erect, arcuate, yellowish hairs, which are denser along lateral margins.

Elytra at base subequal in width to pronotum behind middle; sides parallel, conjointly broadly rounded at apices; disk strongly convex, sometimes with an obsolete longitudinal elevation on each elytron near apical declivity and parallel with suture; surface sparsely, coarsely, irregularly granulose, sparsely, irregularly clothed with long, erect, arcuate, yellowish hairs, the hairs forming a dense fringe along lateral margins, and each arcuate hair on disk having a distinct spur.

Body beneath finely, densely, uniformly granulose, rather densely clothed with long, recumbent, yellowish hairs.

Length 3-5 mm., width $1.5-2.5 \mathrm{~mm}$.

Type locality.-Maine; type probably lost.

Distribution.-This species occurs everywhere in the region east of the Rocky Mountains. Material has been examined from Delaware, District of Columbia, Illinois, Indiana, Iowa, Kansas, Long Island, Maryland, Massachusetts, Michigan, Missouri, New Jersey, New York, North Carolina, Ohio, Pennsylvania, Tennessee, Texas, Virginia, and Manitoba.

Host.-Adults have been reared from the woody fungus, Polyporus gilvus Schw. Blatchley (1910) records it on woody fungi beneath bark of trees and shrubs and also at maple sap in spring.

Dejean $(1835,1836)$ listed this species under the genus $C$ is from "Amerique Boréale," without giving any description. Randall (1838) 
described the species from Maine. placing it in the genus Triphyllus, but Melsheimer (155.3) placed it in the genus Cis. LeConte (18.54) placed it in the genus Endecatomus as a synonym of reticulatus Herbst. and was followed by Lacordaire (185\%). Jacquelin-Dural (18591863). Gemminger and Harold (1869), and Reitter (1911). Horn (1578), recognizing that rugosus Randall was the species listed under that name by Dejean but was not the species described as reticulatum by Herbst, placed dorsatis Mellié as a synonym of rugosus Randall. Specimens of dorsalis from Texas are quite distinct from specimens of rugosus from Massachusetts and certainly represent a valid species.

Endecatomus reticulatus Herbst is listed in our catalogs, but there is some doubt about this European species being found in North America. There are no European specimens of this species in the United States National Museum Collection, and specimens from North America identified as this species do not exactly agree with the figure and description given by Mellié (1848) for reticulatus.

\section{Subfamily DINODERINAE}

Dinoderinae Lesne, 1896, Soc. Ent. de France Ann. 65: $96 ; 1897$, iøid. 66: 319-350: 1s99, ibid. (1898) 67: 435-139; Gardner, 1933. Indian Forest Rec. Ent. Ser. 18 (9) : 3, 6-S (larrae) : Lesne, 1938, in Junk (pub.), Coleopt. Cat., pt. 161, pp. 18-25; Anderson, 1939. Wash. Acad. Sci. Jour. 29: 388 (larrae).

Dinoderina Schilsky, 1899, in Küster and Kraatz, Käfer Europe, r. 36. pp. ss-tt : Everts, 1901, Coleopt. Neerlandica, r. 2, p. 209; Jakobson, 1913, Käfer Russland, pt. 10, pp. 801-803.

Dinoderini Lesne, 1901, Abielle 30: 73, 77-84; Csiki, 1903, Ror. Lapok. X: 17 ; Ererts, 1922, Coleopt. Neerlandica, r. 3, p. 364.

Dinoderidae Lesne, 1921, Assoc. Franç. pour l'Aranc. des Sci., Cong. de Strasbourg (1920), p. 2ST; 1921, Bostrychides de l'Afrique Tropicale Française, pp. 4., $47-19$.

Psoidae (part) Böring and Craighead, 1931, Larrae of Coleoptera, p. 62.

This subfamily is composed of six genera as follows: Rhizoperthodes Lesne, Rhyzopertha Stephens, Stephanopachys Waterhouse. Dinoderus Stephens. Prostephanus Lesne, and Dinoderopsis Lesne, all of which are represented in the Cnited States except Rhizoperthodes and Dinoderopsis.

\section{KEY TO THE GENERA OF DINODERINAE}

1. Clypeus at sides distinctly shorter than labrum; pronotum with lateral margins well marked posteriorly

Clypeus at sides as long as, or longer than, labrum; pronotum without lateral margins, or rarely marked posteriorly with a row of small tubercles.

2. Second segment of antenna shorter than first; pronotum with smooth lateral margins posteriorly, and posterior half of disk punctured; scutellum transverse ................... Dinoderus Stephens, p. 24.

Second segment of antenna subequal in length to first; pronotum with crenulate lateral margins, and posterior half of disk with flattened granules; scutellum quadrate............ Rhyzopertha Stephens, p. 33.

3. Antennal funicle slender, clothed with long hairs, the apical segment of antennal club as wide as, or wider than, preceding segment: pronotum ogival in front; apical declivity of elytra abruptly declivous, with a distinct subapical margin.............. Prostephanus Lesne, p. 36.

Antennal funicle robust, clothed with short hairs, the apical segment of antennal club narrower than preceding segment; pronotum broadly rounded in front; apical declivity of elytra regularlv, arcuately convex, without a distinct subapical margin_Stephanopachys Waterhouse, p. 42. 


\section{Genus DINODERUS Stephens}

Dinoderus Stephens, 1830, Illus. Brit. Ent., Mandibulata, v. 3, Ip. 352-353; Guérin-Ménéville, 1845, Soc. Ent. de France Ann. (ser. 2) 3: Bul. p. xvii; Thomson, 1859, Skandinaviens Coleopt., v. 1, p. 92; Horn., 1878, Amer. Phil. So: Proc. 17: 5+1, 5+8-551 (part); LeConte and Horn, 1883, Smithsn. Inst. Mise. Coilect. 507: 2-8; Waterhouse, 1985, Ann. Mag. Nat. Hist (ser. 6) 1: 348-349; Zoufal, 1894, Wien. Ent. Ztg. 13: 35, 41-42 ; Lesne, 1898, Soc. Ent. de France Ann. (1897) 66: 319, 321-331; Schilsky, 1899, in Küster and Krdatz, Käfer Europas, pt. 36, p. tt; Everts, 1901, Coleopt. Neerlandica, v. 2, pp. 209, 210 ; Lesne, 1901, Abeille 30: 78-81, pl. 1, fig. 11; Fauvel, 1904, Rev. d'Ent. 23 : 156; Reitter, 1911, Fauna Gelmanica, v. 3, pp. 301, 302 ; Jakobson, 1913, Käfer Kussland, pt. 10, p. 802 ; Everts, 1922, Coleopt. Neerlandica, v. 3, p. 364 ; Lesne, 19_4, Bostrychides de rifrique Tropicale \&rangaise, pp. 49, 59-7t, figs. 37-42; Gardner, 1933, Indian Forest Rec., Ent. Ser. 18 (9) : 6-7; Beeson and Bhatia, 1937, Indian Forest Rec. New Ser., Ent. 2: 233-251, figs. 1-4; Lesne, 1938, in sunk (pub.), Coleopt. Cat., pt. 161, pp. 22-25.

I'atea Casey, 1898, N. Y. Ent. Soc. Jour. 6: 66-67; Lesne, 1900, Soc. Ent. de France Bul., p. 46.

Head strongly convex, nearly corered by prothorax and not visible firom above, iront not produced into a lobe on each side of clypeus, transversely depressed behind clypeus; clypeus strongly transverse, broadly, arcuately emarginate in front, at sides shorter than labrum; labrum broadiy rounded and ciliate in front; mentum strongly transrerse, truncate in front: maxillary palpi longer than labial palpi, apical segments long, cultiform; labial palpi with apical segments elongate, acute at apices; mandibles robust. with a triangular tooth on inner margin near middle; eyes strongly projecting, transverse, oblong, abruptly deflexed posteriorly. Intenna 10-or 11-segmented; first and second segments robust, second shorter than first; third to seventh or eighth narrower, more or less transverse, subequal in length; last three segments forming a large loose club, first two segments of club triangular, apical segment oblong, and broadly rounded at apex. Pronotum subglobose, subequal in length and width, broadly rounded in front, rugose and tuberculate in front, granulose or punctate on basal half; sides rounded, distinctly margined posteriorly. Scutellum small, transverse, rectangular. Elytra strongly convex, regularly declivous posteriorly, irregularly punctate. Legs short, subequal in length; tibia slightly expanded toward apices, dentate on exterior margin, anterior pair with an arcuate spine at apices; posterior tarsi shorter than tibiae, last segment of each as long as the preceding four segments united. Anterior and middle coxae contiguous. Body moderately elongate, cylindrical.

Genotype.-Of Dinoderus, Dinoderus ocellaris Stephens. Of Patea, Dinoderus brevis Horn. (Monobasic.)

This genus is of Oriental origin, but many of the species have been distributed to all parts of the world in commerce.

Stephens (1830) erected Dinoderus for A pate substriatus Paykull (identification queried) and Dinoderus ocellaris, new species. His identification of substriatus is not the species described by Paykull under that name, and according to Article 30, section B, of the International Code, "Species which were species inquirendae from the standpoint of the author of the generic name at the time of its publication" are excluded from consideration in determining the types of genera. This leaves only Dinoderus ocellaris Stephens arailable as the genotype of Dinoderus. 
Guérin-Ménéville (18t5) designated Apate elongatus Paykull, a synonvm of Stephanopachys linearis Kugelann, as the type of Linoderus Stephens. Thomson (1859) gave Apate substriatus Paykull as the type of Dinoderus, but this is not the species included in the original description of the genus by Stephens. Taterhouse (1885) stated that there can be no doubt that Dinoderus substriatus. Stephens (not Parkull) is A pate minuta Fabricius from New Zealand, but most unfortunately the type is no longer to be found in the Bauksian collection. Lesne (1895) recorded Apate mimuta Fabricius as the trpe of Dinoderus and not A pate substriatus Paykull. Casey (189s) erected the genus Patea for Linoderus brevis Horn because of its 11secmented antenna. Lesne (1901) placed Patea as a symonvm of Dinoderms. Lesne (191t) erected Dinoderastes as a new subgenus of Dinoderus for three species having the first segment of the anterior tarsus longer than either the third or fourth segments.

\section{KEY TO THE SPECIES OF DINODERUS}

1. First segment of anterior tarsus distinctly longer than either the third or fourth segment ........................ japonicus Lesne, p. 25.

First segment of anterior tarsus not longer than the third or fourth segment

2. Antenna 11-segmented

Antenna 10 -segmented

3. Lateral margins of pronotum extending to anterior row of rasps; basal segments of antenna clothed with long fulvous hairs; elytra with sutural margins of apical declivity elerated; large species, $4 \mathrm{~mm}$.

pubicollis Tan Dyke, p. 26.

Lateral margins of pronotum not extending to anterior row of rasps; basal segments of antenna not clothed with long hairs; elytra with sutural margins of apical declivity not elevated; small species, $3 \mathrm{~mm}$. brevis Horn, p. 27.

4. Pronotum distinctly bifoveolate; elvtra with sutural margins on apical declivit not elerated

Pronotum not di-tinctly bifoveolate; elitra with sutura margins on apical declivity elevated

ocellaris Stephens, p. 28.

5. Apical declivity of elvtra ocellate-punctate_..minutus (Fabricius). p. 30

Apical declivity of elytra areolate-punctate_-bifoveolatus (Wollaston), p. 32

\section{Dirodert's JAPONicLs Lesne}

Dinoderus japonicus Lesne, 1595. Soc. Ent. de France Ann. 64: 170 (separate I. 2) : 1.9S, ibid. (1597) 66:322, 326-327; 1901. Abeille 30: 79-80; 1506. ibid. 30: 2-2: 1914. Sive. Ent. de France Bul., pp. 243-245: Froggatt, 1927, Forest Insects and Timber Borers, p. 97; Lesne, 193s, in Junk (pub.), Coleopt. (at., pt. 161, p. 23.

Dinoderus tsugae Matsumura. 1915, Dainippon Gaichū Zensho ( $\mathrm{r}$ cuil des Borels du Japon). r. 2. p. 1S3. pl. 21. fig. 2 (not seen) : 1931, Nipmon Konchû Daizukan (Grand Atlas des Insects.du Japon), p. 174, fig. 362: Chûjô, 1936. Nat. Hist. Soc. Formosa, Trans. 26: 408.

Brownish black. sometimes with a small, smooth. reddish bosal spot on each elytron. the labrum, palpi. antennae, and tarsi brownish or reddish yellow.

Head coarsely, densely punctate: labrum and clypeus indistinctly punctate. the latter clothed at sides with long, erect. vellowish hairs. Antenna 11-segmented: funicle sparsely clothed with short. erect. rellowish hairs: antennal club densely clothed with short. recumbent. yellowish hairs: first segment oblong. twice as long as wide; second segment oval, slightly narrower than first.

Pronotum strongly convex, widest near basal third, without foveae near base; sides broadly rounded, more obliquely anteriorly, lateral 
margins sometimes extending to anterior row of teeth; surface sparsely clothed with short, semierect, yellowish hairs, which are longer toward margins, basal half coarsely, densely, but not confluently ocellate-punctate, the punctures fine and slightly asperate at middle, apical half with concentric rows of broad, sharp, rasplike teeth, the two median ones on anterior row contiguous at bases and longer than lateral ones, the intervals between teeth finely, densely ocellate-punctate.

Elytra twice as long as pronotum; sides slightly expanded posteriorly; sutural margins on apical declivity slightly elevated; surface sparsely clothed with short, erect, rather stiff, yellowish hairs, densely, coarsely, uniformly ocellate-punctate, the punctures distinctly separated on apical declivity, intervals finely, densely granulose.

Body beneath densely, finely granulose, rather densely clothed with long, recumbent, yellowish hairs; first segment of anterior tarsus distinctly longer than either the third or fourth segment, and clothed with long hairs.

Length 3-4 mm., width 1.2-1.5 mm.

Type locality.-Japan, no definite locality; type in Paris Museum.

Distribution.-This species has been recorded from Japan, China, and Australia. Specimens have been examined from bamboo, which was intercepted at the following localities:

Arizona : Tucson, March 20, 1939 (L. P. Wehrle).

California : San Jose, October 10, 1914 (G. B. Howard).

GEoRgra : Savannah, August 2, 1937.

Illinors : Urbana, February 8, 1933 (Mohr and Waldron).

Marne: Augusta, January 12, 1932 (H. P. Peirson).

MassachusetTs: Melrose Highlands, April 6, 1923.

Mrssouri : St. Louis, July 25, 1942 (B. D. Brayton).

\section{Host.-Bamboo.}

Lesne (1895) described this species from a unique specimen in the Paris Museum without mentioning the number of segments in the antenna. In 1898 he placed it with the species having 10 segments in the antenna, but in 1914 placed it in his new subgenus Dinoderastes, stating that the antenna was composed of 11 segments. Matsumura (1915) described a species of this genus from Japan under the name of tsugae, but Chûjô (1936), after examining the type, placed it as a synonym of japonicus Lesne.

\section{Dinoderus pubicollis Van Dyke}

Dinoderus pubicollis Van Dyke, 1923, Brooklyn Ent. Soc. Bul. 18: 45-46; Lesne, 1938, in Junk (pub.), Coleopt. Cat., pt. 161, p. 25.

Since the writer has not examined the type of pubicollis, and the species is placed in the key solely upon the characters given in the original description, it seems advisable to include the following copy of the original description:

Cylindrical, moderately short, somewhat shining, piceous, antennae rufous and tarsi rufo-castaneous. Head with long fulvous hairs about mouth-parts and on basal joints of antennae, regularly rather closely and deeply punctate and strigose posteriorly; the antennae eleven-jointed, the first joint large, the second almost spherical and narrower and about one-half length of first, the first and second joints of club transverse, the last about as long as broad. Prothorax as broad as long, the anterior half with six concentric rows of sharp rasplike teeth, the individual teeth more or less united and more prominent in front, 
the area between the rows rather finely, closely and ocellately punctate and pilose, the hairs fulvous and semierect, the posterior half distinctly and moderately, closely punctate with ocellate punctures, the punctures somewhat larger than in front and slightly asperate on disk, the sides with long fulvous hair, the lateral margin distinct and just reaching the end of the anterior row of rasps, the hind angles well rounded. Elytra slightly less than twice as long as prothorax and not quite twice so long as wide; coarsely, moderately densely, regularly and ocellately punctured, the punctures larger than on pronotum and with slight tendency to form rows near suture; the surface sparsely clothed with short erect fulvous setae, more numerous on declivity, the suture slightly elevated on declivity and with faint sulci on either side; the lateral margin at first obliquely curving away from the base, then horizontal at middle and again gradually and obliquely curved downwards to the apex. Beneath rather finely, sparsely punctate anteriorly, more finely and closely on the abdomen, subopaque, and pilose. Length $4 \mathrm{~mm}$., breadth $1.5 \mathrm{~mm}$.

This species differ's from $D$. brevis Horn, the only other species from this country in the genus as it is now restricted by Lesne by being considerably larger, proportionally longer, with eleven-jointed antennae instead of ten, by having the lateral margin of the prothorax reaching the first row of rasps, the prothorax more distinctly pilose anteriorly and laterally, and by having the lateral margin of the elytra obliquely retreating from the base and forming an angle where it meets it, the sides of the elytra near the base therefore narrower. Its only close relative is apparently $D$. nitidus Lesne from the Marquis Is., a species which possesses also eleven-jointed antennae and has the lateral thoracic margin reaching the anterior rasps. It, however, differs from this by possessing an aural pilosity, ocellate punctures on both head and prothorax, and a distinct pubescence of the sides of the prothorax. It can not be the unrecognized $D$. cellaris Steph. either, for the elytral punctures are not 'disposed in striae' and the antennae piceous.

Type and nine paratypes in my collection, all collected by myself at Los Angeles, California. They were secured many year's ago and, as I remember it, dug out of some mesquite cord wood stored in our cellar for fire wood. Just where the wood was cut, I could not say.

DiNoderus BRevis Horn

Dinoderus brevis Horn, 1878, Amer. Phil. Soc. Proc. 17 : 549, 5ॅ0-5.51 ; Anonymous, 1894, Insect Life 6: 274; Chittenden, 1895, Insect Life 7: 327-32s ; Lesne, 1s96, Soc. Ent. de France Bul., p. 334; 1897, Bul., p. 147; 1S98, Soc. Ent. (le France Ann. (1S97) 66: 323, 331, figs. 11, 19 ; 1S99, Mus. Civ. Genova, Ann. (ser. 2) (1898) 19: 630; 1904, Abeille 30: 154; Jakobson, 1913, Käfer Russland, pt. 10, p. 802 ; Stebbing, 1914, Indian Forest Insects, pp. 143-144; Runner, 1919, U. S. Dept. Agr. Bul. 737, p. 29 ; Lesne, 1926, Treubia 7 : 11S-119; Beeson and Bliatia, 1937, Indian Forest Rec., New Sier., Ent. 2: 2:5, 2*2s, 233-253, 309-320, fig. 2; Lesne, 1938, in Junk (pub.), Coleopt. Cat., pt. 161, p. 23 ; Belkin, 1940, Ent. News 51 : 193 ; Boyd, 1944, N. Y. Ent. Soc. Jour. 52 : 200.

Reddish brown, pronotum usually darker, the palpi, tarsi, and antennal club brownish yellow.

Head coarsely, densely, uniformly punctate; labrum and clypeus sparsely punctate, the latter sparsely clothed with short, inconspicuous, erect hairs. Antenna 11-segmented; funicle sparsely clothed with short, erect, yellowish hairs; antennal club densely clothed with short. recumbent, yellowish hairs; first segment oblong; second segment oval, as wide as first.

Pronotum strongly convex, widest at basal fourth. distinctly bifoveolate near base; sides broadly rounded, more obliquely anteriorly. lateral margins not extending to anterior row of teeth; surface sparsely clothed with very short. inconspicuous hairs, basal half finely ocellatepunctate, more coarsely, distantly toward sides, apical half with concentric rows of broad, rasplike teeth, which are more prominent anteriorly, and acutely rounded at apices with the two median teeth widely separated along anterior margin, the intervals between teeth obsoletely ocellate-punctate. 
Elytra one and one-half times as long as pronotum; sides parallel; sutural margins not elevated on apical declivity; surface sparsely clothed with short, erect, rather stiff, yellowish hair's, coarsely, densely, aniformly ocellate-punctate, the punctures on apical declivity distinctly separated, intervals not distinctly gramulose.

Body beneath densely, finely granulose, shallowly, obsoletely punctate, sparsely clothed with moderately long, recumbent, yellowish hairs; first segment of anterior tarsus not longer than the third or fourth segment.

Length 2.6-3 mm., width 1-1.5 mm.

Type locality.-New Orleans. La.; type in Horn Collection in the Academy of Natural Sciences of Philadelphia.

Distribution.-This is the common bamboo borer in. India. It has been recorded from Indo-China, Siam, Borneo, Malasia, India, China, Burma, Malay Peninsula, Philippine Islands, Sunda Islands, and Jamaica. Specimens have been examined from India, China, Burma, and the Philippine Islands. Specimens have been intercepted in bamboo at the following localities:

District of Columbia: Washington.

Minnesota : St. Paul.

NEw Jersey: Hoboken; Trenton.

TExas : Galveston.

WASHINGToN : Seattle.

Hosts.-Beeson and Bhatia (1937) stated that this species primarily breeds in bamboos, and the food plants of the larvae are restricted to bamboos and canes. It has been recorded in the literature as attacking the following host plants: Albiesia odoratissima, Atrocarpus hirsuta, Balanites roxburghii, Butea frondosa, Ficus bengalensis, Lannea grandis. Mangifera indica, Pinus kharya (bark on logs), Shorea roLusta, Sonneratia apetala, Sterculia campanulata, Bambusa polymorpha, B. arundinacea. Dendrocalamus strictus, and Tectona grandis.

Horn (1878) described this species from adults emerging from the bamboo handle of a Japanese fan. Stebbing (1914) recorded this species as infesting the bamboo (Dendrocalamus strictus) in the roofs of bungalows in India, and also the Sál (Shorea robusta) posts used in supporting the bungalow roofs.

\section{Dinoderus ocellaris Stephens}

Dinoderus ocellaris Stephens, 1830, Illus. Brit. Ent., Mandibulata, v. 3, p. 352; IVestwood, 1839, Introduction to the Classification of Insects, v. 1, p. 278; Lesne, 1s98, Soc. Ent. de France Ann. (1897) 66:331; 1905, Abeille 30:249; Jakobson, 1913, Käfer Russland, pt. 10, p. 802; Gardner, 1933, Indian Forest Rec. Ent. Ser. 18: 8 (larva) ; Beeson and Bhatia, 1937, Indian Forest Rec. New. Ser., Ent. 2 : 225, 229, 233-251, 255-256, 309-319, fig. 2 ; Lesne, 1938, in Junk (pub.), Coleopt. Cat., pt. 161, p. 25.

$1)^{*}$ noderus pilifions Lesne, 1895, Soc. Ent. de France Ann. 64: 170 (separate p. 2) ; 1897, Soc. Ent. de Belg. Ann. 41: 18; 1S98, Soc. Ent. de France Ann. (1897), $66: 322$, 327, figs. 16, 20a ; 1899, Mus. Civ. Genova Ann. (189s) (ser. 2) 19 : 629, 637-638; Donisthorpe, 1900, Ent. Rec. and Jour. Variation 12: 16-18; Stebbing, 1903, Notes on Insects that Affect Forestry (India), No. 2, pp. 168-171, pl. 8, figs. 1a-b; Lesne, 1904, Abeille 30: 154; 1905, ibid. $30: 249$; Lefroy, 1909, Indian Insect Life, p. 316; Stebbing, 1914, Indian Forest Insects, pp. 4, 14, 130-133, 186, 188, figs. 89-90 ; Cann, 1935, Indian Forester 61 : 165 ; Lesne, 1938, in Junk (pub. ), Coleopt. Cat., pt. 161, p. 25.

Reddish brown, the labrum, palpi, antennae, legs and abdomen in part, brownish yellow. 
Head coarsely, densely punctate on vertex, nearly smooth behind clypeus: clypeus sparsely punctate, rather densely clothed with long, erect hairs, especially toward sides; labrum not distinctly punctate. Antemnae 10-segmented; funicle sparsely clothed with long, erect, yellowish hairs; antennal club densely clothed with short, recumbent. yellowish hairs: first segment elongate, arcuate, flattened, twice as long as wide; second segment oval, much narrower than first.

Pronotum strongly convex, widest near middle, without distinct foreae near base; sides broadly rounded, lateral margins not extending to anterior row of teeth: surface sparsely clothed with short. inconspicuous, erect hairs, the hairs longer toward sides, basal half finely, but not distinctly ocellate-punctate, the intervals finely, obsoletely granulose, apical half with concentric rows of broad, rasplike teeth, these more prominent anteriorly, acutely rounded at apices, and sometimes contiguous at bases along anterior margin, the intervals between teeth finely, obsoletely ocellate-punctate.

Elytra twice as long as pronotum; sides slightly expanded posteriorly: sutural margins distinctly elevated on apical declivity; surface rather densely clothed with short, erect, rather stiff, yellowish hairs, the hairs fine and rery short on disk, coarsely, densely, uniformly ocellate-punctate on disk, confluently areolate-punctate on apical declivity, intervals obsoletely granulose.

Body beneath finely, densely granulose and shallowly punctate. sparsely clothed with moderately long, recumbent, yellowish hairs: first segment of anterior tarsus not longer than the third or fourth segment.

Length 3-1 mm., width 1.2-1.5 mm.

Type Tocality.-Of ocellaris, Little Chelsea. England; type in the Oxford Cniversity Museum. Of pitifrons, Hindostan; type in the Paris Museum.

Distribution.-This is one of the common bamboo borers of northern India. It has been recorded from all parts of India, and from Ceylon, Indo-China. Hindostan, Celebes, New Guinea. Philippines, and the Sunda Islands. Specimens have been examined from India and the Philippines. Specimens have been intercepted in bamboo at the following localities:

Louisiana : New Orleans.

NEw York: New York.

Oregox: Portland.

Texas: Houston.

Washixgtox: Seattle.

Hosts.--Beeson and Bhatia (1937) recorded that the normal breeding material is bamboo and all authentic records showed that the larvae are restricted to the bamboos. The adults have been recorded as attacking Dendrocalamus strictus. Oxytenanthera nigrociliata. Ficus bengalensis, Grewia titiaefotia, Pinus khamya (bark). P. Tongifolia. Shorea robusta. Sterculia urens. Tamarix dioica. Tectona grandis, Terminatia tomentosa, and Dipterocarpus alatus.

Stephens (1830) described ocellaris from a single specimen, from the Westrood Collection, found floating in a cup of coffee. Lesne (1895) described pilifrons from Hindostan and he (1S9s) stated that ocellaris was unknown to him, but after having Poulton examine the type of ocellaris. preserved in the Museum of the University of Oxford. he (1905) placed his pitifrons as a synonym of ocellaris Stephens. 
This species has been collected a number of times on the piers at various ports in Europe, and the adults are numerous on packet boats coming from the Orient. Cann (1935) recorded the adults making galleries in the teak (Tectonia grandis) and gurjum (Dipterocarpus alatus) timbers shipped from India to London, but that the beetles made no attempt to breed in these woods, probably migrating from infested bamboo on board the ships.

\section{Dinoderus minutus (Fabricius)}

Apate minutus Fabricius, 1775, Systema Entomologiae, p. 54; 1781, Species Insectorum, v. 1, p. 62 ; 1787, Mantissa Insectorum, v. 1, p. 33; 1792, Entomologia Systematica, v. 1. pt. 2, p. 363; Herbst, 1793, Natursystem Insekten, Käfer, v. 5, p. 78; Fabricius, 1801, Systema Eleutheratorum, v. 1, p. 383 ; Boisduval, 1835, Voyage de l'Astrolabe, pt. 2, p. 461.

Bostrichus minutus Olivier, 1790, Encyc. Méthodique, v. 5, pp. 107, 111; 1795, Entomologie, v. 4, Gen. 77, p. 15, pl. 2, figs. 12a-b.

Dinoderus minutus Lesne, 1896, Soc. Ent. de France Bul., p. 334; 1896, Ann. 65 : 126, pl. 8, fig. 15 ; 1897, Soc. Ent. de Belg. Ann. 41: 18; 1898, Soc. Ent. de France Ann (1897) 66: 323, 329-330, figs. 12, 17, 18, 20, 23, 24, 27a; 1899, Mus. Civ. Genova Ann. (1898) 19: 630; Schilsky, 1899, in Küster and Kraatz, Käfel Europas, pt. 36, No. 97; Donisthorpe, 1900, Ent. Rec. and Jour. Variation 12 : 16-18; Lesne, 1901, Abeille 30:70, 80, pl. 1, figs. 11, 15; Everts, 1901, Coleopt. Neerlandica, v. 2, p. 210 ; Stebbing, 1903, Notes on Insects that Affect Forestry (India ), No. 2, pp. 172-173 ; Fauval, 1904, Rev. d'Ent. 23 : 156-157; Lesne, 1904, Abeille 30: 154; Stebbing, 1906, Notes on Insects that Affect Forestry (India), No. 3, pp. 355-363, pl. 20, fig. 8, pl. 21, fig.; Lefroy, 1909, Indian Insect Life, p. 316 ; Reitter, 1911, Fauna Germanica, v. 3, p. 302 ; Jakobson, 1913, Käfer Russland, pt. 10, p. 802 ; Lesne, 1914, Soc. Ent. de France Bul., p. 242, fig. 1; Stebbing, 1914, Indian Forest Insects, pp. 4, 14, 18, 19, 133-143, 186, 188, 355, pl. 9, figs. a-d ; D'Emmerez, 1915, Mauritius Dept. Agr. Sci. Ser. Bul. No. 2, p. 7, pl. 1, figs. 1, 3 ; Everts, 1922, Coleopt. Neerlandica, v. 3, p. 364 ; Lesne, 1924 , Bostrichides de l'Afrique Tropicale Française, pp. 61, 64-68, figs. 7, 8, 13, 38; 1926, Treubia 7: 118; Gardner, 1933, Indian Forest Rec. Ent. Ser 18 (9): 8 (larva) ; Miller, 1934, Straits Settlements and Fed. Malay States, Dept. Agr., Sci. Ser. No. 14, pp. 1, 2, 5, 9, 21-23, pl. 1, figs. 12-15; Knull, 1934, Ent. News 45: 209 ; Beeson and Bhatia, 1937, Indian Forest Rec. New Ser., Ent. 2 : 225, 229, 233-251, 254-255, 309-320 : Lesne, 1938, in Junk (pub.), Coleopt. Cat., pt. 161, p. 24; Back and Cotton, 1938, U. S. Dept. Agr. Farmers' Bul. 1260 (revised), p. 8; Lesne, 1939, Rev. Franç. d' Ent. 6: 91-94; Anderson, 1939, Wash. Acad. Sci. Jour. 29 : 385, figs. 3, 6 (larvae) ; Tooke and Scott, 1944, So. Africa Dept. Agr. and Forestry Bul. 247 (Ent. Ser. 14), p. 7, fig. 4; Lever, 1945, Bul. Ent. Res. $35: 374$.

Dinoderus bifoveolatus Zoufal (not Wollaston), 1894, Wien. Ent. Ztg. 13 : 41-42 ; Chittenden, 1895, Insect Life $7: 327-328$.

Dinoderus substriatus Stephens (not Paykull), 1830, Illus. Brit. Ent., Mandibulata, r. 3, pp. 352-353; Waterhouse, 1888; Ann. and Mag. Nat. Hist. (ser. 6) 1: $348-349$.

Bostrichus vertens Walker, 1859, Ann. and Mag. Nat. Hist. (ser. 3) $3: 260$.

Rhi opertha sicula Baudi, 1873, Berlin. Ent. Ztschr. 17 : 336-337; 1873, Mus. Civ. Genova Ann. 4 : 265.

Dinoderus japonicus Matsumura (not Lesne), 1915, Dainippon Gaichû Zensho (Recueil des Borers du Japon), v. 2, p. 184, pl. 28, fig. 12 (not seen) ; 1931, Nippon Konchû Daizukan (Grand Atlas des Insects du Japon), p. 174, fig. 361; Chûjô, 1936, Nat. Hist. Soc. Formosa Trans. $26: 408$.

Reddish brown to brownish black, sometimes elytra more reddish than rest of dorsal surface; labrum, palpi, antennal club, and tarsi usually brownish yellow.

Head coarsely, densely, uniformly punctate; labrum and clypeus indistinctly punctate, the latter sparsely clothed with short, inconspicuous, erect hairs. Antenna, 10-segmented; funicle sparsely clothed with short, erect, yellowish hairs; antennal club densely clothed with 
short, recumbent, yellowish hairs ; first segment oblong, twice as long as wide; second segment oval, as wide as first.

Pronotum strongly convex, widest at basal third, distinctly bifoveolate near base; sides broadly rounded, more obliquely so anteriorly, the lateral margins not extending to anterior row of teeth; surface sparsely clothed with short, semierect hairs, basal half granulose on medium part, coarsely, rather densely but not confluently, ocellate-punctate at sides, apical half with concentric rows of broad, rasplike teeth, which are more prominent anteriorly, acutely rounded at apices, and distinctly separated at bases along anterior margin, intervals between teeth obsoletely ocellate-punctate.

Elytra one and one-half times as long as pronotum; sides parallel; sutural margins not elevated on apical declivity ; surface rather densely clothed with short, erect, rather stiff, yellowish hairs, the hairs sparser and finer on disk, coarsely, shallowly, more or less confluently ocellatepunctate on disk, the punctures distinctly separated on apical declivity, intervals not distinctly granulose.

Body beneath finely, densely granulose, and shallowly punctate, sparsely clothed with rather short, recumbent, yellowish hairs; first segment of anterior tarsus not longer than the third or fourth segment.

Length 2.6-3.5 mm., width 1-1.5 mm.

Type locality.-Of minuta, New Zealand; type probably lost. Of vertens, Ceylon. Of sicula, Sicily. Of japonicus, Japan. The present locations of the types of vertens, sicula, and japonicus are unknown to the writer.

Distribution.-This is the most common species of Dinoderus. It is cosmopolitan throughout the tropical regions, but has been carried in commerce to all parts of the Temperate Zones. It has been intercepted many times in various parts of the United States, and will be found breeding wherever dry bamboo is stored.

Hosts.-This species prefers the wood of bamboo, principally in the genera Dendrocalamus and Phyllostachys. According to authentic records the host plants of the larvae are restricted to bamboos and canes. The adults attack many kinds of timber, plants, and regetable products. The adults have been recorded by Beeson and Bhatia (1937) as attacking Dendrocalamus giganteus, D. strictus, Oxytenanthera nigrociliate, Phyllostachys sp., Albizzia stipulata, Bambusa arundinacea, Dendrocalamus hamiltonii, and Melia azedarach in India; Bombax malabaricum (stacked planks), Camellia thea, Vateria indica (logs), and Warmia triquetra (logs) in Ceylon; in Erythrina indica and maize in Mauritius and Java; Persea gratissima (bark and seeds) in Zanzibar; Pinus kharya (bark) in India; Poinciana elata (wood) in Madras; Shorea robusta (wood) in United Provinces; Smilax borbonica (dry roots) in Reunion Islands; Spondias mangifera and Tectona grandis (timber) in Burma; tobacco (baled) in Java and Sumatra; and Thespesia populnea (wood) in Bombay. Miller (1934) recorded the species in the Malay Peninsula as attacking rubber (Hevea brasitiensis), guava (Psidium guajava), cinnamon (Cinnamomum zeylandicum), Indigofera anit, Cashew nut (Anacardium. occidentale), Durian (Durio zibethius), Nephelium lappaceum, and Crotalaria anagyroides.

The adults are also recorded as attacking sugarcane, dried sweetpotatoes, rice, banana preparations, and is frequently found breeding 
in rattan articles and wooden packing cases. Miller (1934) stated that this species is the most important pest of maize in Mauritius and in Zanzibar. This species reduces all structures built of bamboo to dust in a few years. It has been intercepted in Arundo donax and Merostachys racimaflora from Mexico.

Fabricius (1775) described this species from a specimen in the Banks Collection from New Zealand. Stephens (1830) misidentified this species as substriatus Paykull from a specimen collected in England and placed it in his genus Dinoderus. Waterhouse (1888) stated that, after examining the specimen identified as substriatus by Stephens, there could be no doubt that it is A pate minuta Fabricius, from New Zealand, but most unfortunately the type of minuta is no longer to be found in the Banks Collection. Walker (1859) described vertens from Ceylon. Baudi (1873) described Rhizopertha sicula from Sicily. Matsumura (1915) described this species as japonicus (not Lesne). Lesne (1898) placed substriatus Steph. (not Payk.), siculus Baudi, and bifoveolatus Zoufal (not Wolls.) as synonyms of minutus F. and he (1938) also included vertens. Walker and japonicus Matsum. (not Lesne) as synonyms of this species.

Dinoderus Bifoveolatus (Wollaston)

Rhisopertha bifoveolata Wollaston, 185S, Ann. and Mag. Nat. Hist. (ser. 3) 2:409410 ; 1865, Coleopt. Atlantidum, p. 232, app. p. 39 ; 1867, Coleopt. Hesperidum, pp. 110-111; Gorham, 1S98, Zool. Soc. London, Proc., pp. 329-330, pl. 27, fig. 9. Dinoderus bifoveolatus Lesne, 1898, Soc. Ent. de France Ann. (1897) $66: 323,328-$ 329; 1899, Mus. Civ. Genova, Ann. (1S9S) (ser. 2) 19:630; Donisthorpe, 1900, Ent. Rec. and Jour. Variation 12:16-18; Lesne, 1901, Abeille 30:79-80, pl. 1, fig. 16; Fauvel, 1901, Rer. d'Ent. 23: 156; Reitter, 1911, Fauna Germanica, v. 3, p. 302 ; Jakobson, 1913, Käfer Russland, pt. 10, p. 802 ; Everts, 1922, Coleopt. Neerlandica, v. 3, p. 364; Lesne, 1924, Bostrychides de l'Afrique Tropicale Française, pp. 62, 72-74, fig. 42; Miller, 1934, Straits Settlements and Fed. Malay States, Dept. Agr. Sci. Ser. No. 14, pp. 1-2, 24, pl. 2, fig. 11; Beeson and Bhatia, 1937, Indian Forest Rec. New Ser., Ent. 2 : 225, 228, 251-252, 309-315 ; Lesne, 193S, in Junk (pub.), Coleopt. Cat., pt. 161, p. 23.

Dinoderus perpunctatus Lesne, 1895, Soc. Ent. de France Ann. 66 : 170 (separate p. 2$)$; 1897 , Soc. Ent. de France Bul., p. 147.

Reddish brown, clypeus, labrum, palpi, antennae, legs, and sometimes base of elytra, slightly paler.

Head coarsely, densely, uniformly punctate, smooth behind clypeus; labrum and clypeus not distinctly punctate, the latter sparsely clothed with long, erect hairs. Antenna 10-segmented; funicle sparsely clothed with short, erect, yellowish hairs; antennal club densely clothed with short, recumbent, yellowish hairs; first segment oblong, twice as long as wide; second segment oval, as wide as first.

Pronotum strongly convex, widest at basal fourth, bifoveolate near base; sides broadly rounded, more obliquely anteriorly, the lateral margins not extending to anterior row of teeth: surface sparsely clothed with short, inconspicuous, erect hairs on median part, the hairs longer and more distinct toward margins, basal half coarsely ocellatepunctate, separated at sides and more or less confluent at middle, apical Jalf with concentric rows of broad, broadly rounded, rasplike teeth, which are more prominent anteriorly, and contiguous at bases, forming a crenulate ridge along anterior margin, the intervals between teeth densely ocellate-punctate.

Elytra nearly twice as long as pronotum; sides parallel; sutural margins not elevated on apical declivity; surface sparsely clothed with 
short, erect, rather stiff, yellowish hairs on apical declivity, nearly glabrous, and coarsely, densely, uniformly punctate on disk, densely areolate-punctate on apical declivity, intervals smooth.

Body beneath finely, densely granulose and shallowly punctate, sparsely clothed with moderately long, recumbent, yellowish hairs; first segment of anterior tarsus not longer than the third or fourth segment.

Length $2.4-2.7 \mathrm{~mm}$. . width $1-1.2 \mathrm{~mm}$.

Type locality.-Of bifoveolatus, Madeira Islands; present location of type unknown to writer. Of perpunctatus. tropical regions (no definite locality given); types in the Paris and Brussels Museums.

Distribution.-This species has been recorded from all parts of the world. It is cosmopolitan in the tropical regions, but is distributed to the colder regions in commerce. Specimens hare been examined from many places in the United States. where it has been intercepted in roots of derris, barbasco, cube, Jalapa, and Huira-Huira, and in wooden packing cases. It will probably be found whererer these roots are stored, but so far has not been reported infesting grains or cereal products in the United States.

Hosts.-Beeson and Bhatia (1937) recorded this species in Artocarpus hirsuta, Kydia calycina, and Mangifera indica, and stated that it is a wood borer, and in Africa bores into canes and palm leares used for making baskets and cases. Lesne (1924) recorded this species living in woody tissues, such as the stalks of Calamus used for making baskets in New Guinea. It also lires in the ribs of leaves of the Sago trees used in the construction of dwellings in Africa, and is found burrowing in the dry roots of Manioc and yam. It is also found in meals, principally yam, palm, and wheat. Miller (1931) recorded it as being a well-known pest of grain.

Wollaston (1858) described biforeolatus from eight specimens collected at Funchal, in the Madeira Islands, in a barrel of flour, which had remained about a year in the customhouse and had become spoiled. Lesne (1895) described perpunctatus from the tropical regions, but later (18.98) placed it as a synonym of bifoveolatus.

\section{Genus RHYZOPERTHA Stephens}

Rhyzopertha Stephens, 1830, Illus. Brit. Ent., Mandibulata, v. 3, p. 35t; Wollaston, 1854, Ins. Maderensia, pp. 286-28s; Linsley, 1934, Jour. Econ. Ent. 36: 126.

Rhizopertha Guérin-Ménérille, 1945, Soc. Ent. de France Ann. (ser. 2) 3: Bul., p. xrii; Agassiz, 1846, Nomenclator Zoologicus, pt. 11, Coleoptera p. 142 : Lacordaire, 1857, Genera des Coléopt., г. 4, pp. 534, 541-542: Redtenbacher, 1858, Fauna Austriaca, Käfer (ed. 2), pp. C1., 570: Jacquelin-Dural. 1559-1863, Genera Coléopt. Europe, v. 3, pp. 231-233, pl. 57, fig. 2S1: LeConte, 1861, Smithsn. Inst. Misc. Collect. 3 (1) : 208; Redtenbacher, 1874, Fauna Austriaca, Käfer (ed. 3), pt. 1, p. cxii, pt. 2, pp. 66-67; Kiesenwetter, 1S7 7 , in Erichson, Nat. Ins. Deutsch. Coleopt., r. 5, pt. 1, pp. 40-41; Seidlitz. 1589, Fauna Transsylranica, Kaefer, pp. 117, 530: 18s9, Fauna Baltica, Kaefer, pp. 117. 496 ; Zoufal, 1894, Wien. Ent. Ztg. 13: 35, 41; Lesne, 1897, Soc. Fnt. de France Ann. 66: 319, 332-333; Schilsky, in Küister and Kraatz, Käfer Europas, 36: tt; Lesne, 1901, Abeille 30: 78-81, fig. 12 ; Everts, 1901, Coleopt. Neerlandica. r. 2, p. 210; Reitter, 1911, Fauna Germanica, v. 3, pp. 301, 302 ; Jakobson, 1913 ; Käfer Russland, pt. 10, p. 802: Lesne, 1924, Bostrychides de l'Afrique Tropicale Française, pp. 49-59; 1938, in Junk (pub.), Coleopt. Cat., pt. 161, pp. 1s-19.

Head slightly convex, partially covered by prothorax, not visible from above, the front not produced into a lobe on each side of clypeus; clypeus strongly transverse, broadly, arcuately emarginate in front, 
at sides shorter than labrum; labrum broadly rounded or subtruncate, and ciliate in front; mentum transverse, broadly rounded in front; maxillary palpi slightly longer than labial palpi, apical segment of each long, subfusiform, acute at apex; apical segment of labial palpus slightly shorter than maxillary; mandibles robust, acute at apices, broadly toothed on inner margins near apices; eyes slightly projecting. transverse, oblong. Antenna short, 10-segmented; first and second segments robust, rounded, subequal in length; third to seventh narrow, very small, subequal in length; eighth to tenth segments forming a large, loose club, the segments broad, eighth and ninth more or less triangular, the tenth oblong. Pronotum subglobose, subequal in length and width, rugose and tuberculate anteriorly, with flattened granules on posterior part; sides rounded, at most only slightly margined near posterior angles. Scutellum small, quadrate. Elytra elongate, strongly convex, stria-punctate, obliquely declivous posteriorly. Legs short, subequal in length; tibiae slightly expanded toward apices. dentate on exterior margins, anterior pair with an arcuate spine at apices; posterior tarsi shorter than tibiae, apical segment as long as preceding four segments united. Anterior coxae contiguous. Middle coxae very narrowly separated. Body elongate, cylindrical.

Genotype.-Synodendron pusillum Fabricius. (Monobasic.)

Rhyzopertha is the original spelling for this genus with Synodendron pusillum Fabricius as the monobasic genotype. Guérin-Ménéville (1845) and Agassiz (1846) emended Rhyzopertha to Rhizopertha, the latter name being used by nearly all writers after that date, but the present writer prefers to use the original spelling.

\section{Rhyzopertha dominica (Fabricius)}

Synodendron dominicum Fabricius, 1792, Entomologie Systematica, v. 1, pt. 2, pp. $359-360$.

Synodendron pusillum Fabricius, 1798, Entomologie Systematica, Sup. p. 156. Sinodendron dominicum Fabricius, 1801, Systema Eleutheratorum, v. 2, p. 378. Sinodendron pusillum Fabricius, 1801, Systema Eleutheratorum, v. 2, p. 378.

Rhyzopertha pusilla Stephens, 1830, Illus. Brit. Ent., Mandibulata, v. 3, p. 354 ; Wollaston, 1854, Ins. Maderensia, pp. 287-288; Chevrolat, 1861, Soc. Ent. de France Ann. (ser. 4). 1: 392.

Rhizopertha pusilla Bach, 1852, Käferfauna für Nord und Mitteldeutschland, v. 2, pt. 3, p. 118 ; Jacquelin-Duval, 1859-1863, Genera Coléopt. Europe, r. 3, p. 167, pl. 57, fig. 281 ; Fowler, 1890, Coleopt. Brit. Is. 4 : 200-201, pl. 119, fig. 1.

Rhizopertha dominica Lesne, 1896, Soc. Ent. de France Bul., p. 334; 1897, Soc. Ent. de France Ann. 66: 332-333, figs. 13, 21, 27b; Fauval, 1904, Rev. d'Ent. 23: 157; anonymous, 1908, U. S. Dept. Agr. Yearbook, p. 579; Lefroy, 1909, Indian Insect Life, p. 316 ; Reitter, 1911, Fauna Germanica, v. 3, p. 302, pl. 120, fig. 10 ; Chittenden, 1911, U. S. Dept. Agr. Bur. Ent. Bul. 96, pt. 3, pp. 29-47, figs. 7-8; Morrill, 1917, Ariz. Comm. Agr. and Hort. Rpt. 9, p. 59 ; Chittenden, 1919, U. S. Dept. Agr. Bul. 783, p. 9; Doane, 1919, Jour. Econ. Ent. 12: 312 ; Back and Cotton, 1922, U. S. Dept. Agr. Farmers' Bul. 1260, pp. 10-13, figs. 11-12; Froggatt, 1927, Forest Insects and Timber Borers, p. 98; Leonard, 1928, N. Y. (Cornell) Agr. Expt. Sta. Mem. 101: 416; Hoffman, 1933, Jour. Econ. Ent. 26 : 293-294; Gardner, 1933, Indian Forest Rec. Ent. Ser. 18 (9) : 6-7, pl. 3, figs. 32-36 ; Schwardt, 1933, Kans. Ent. Soc. Jour. 6: 61-66; Fleury, 1933, Calif. Dept. Agr. Spec. Pub. 119 : 30 ; Stracener, 1934, Jour. Econ. Ent. 27: 767-771; Potter, 1935, Roy. Ent. Soc. London Trans. 83 (4) : 449-482, figs. 1-25; Beeson and Bhatia, 1937, Indian Forest Rec. New Ser., Ent. 2: 22S, 282-284, 309-319; Lesne, 1938, in Junk (pub.), Coleopt. Cat., pt. 161, pp. 18-19; Anderson, 1939, Wash. Acad. Sci. Jour. 29 : 388, fig. 5 (larrae) ; Crombie, 1941, Jour. Expt. Biol. 18: 62-79, fig. 1; Balzer, 1942, U. S. Dept. Agr. Farmers' Bul. 1906, pp. 1-22, figs. $1-15$.

Dinoderus pusillus Holn, 1878, Amer. Phil. Soc. Proc. 17 : 549, 550 ; Riley, 1882, Amer. Nat. 16: 747; Gorham, 1883, Biol. Centr.-Amer., Coleopt., v. 3, pt. 2, 
p. 217 ; Riley, 1894, Insect Life 6:219; Chittenden, 1896, U. S. Dept. Agr., Div.

Ent. Tech. Ser. 4, p. 28; Casey, 1S9S, N. Y. Ent. Soc. Jour. 6: 76 ; Blatchley, 1910,

Coleoptera of Indiana, pp. 890,891 .

Ptinus piceus Marsham, 1802, Ent. Britannica, v. 1, Coleoptera, p. 88.

Ptinus fissicornis Marsham, 1802, Ent. Britannica, v. 1, Coleoptera, p. 82.

A pate rufa Hope, 1845, Ent. Soc. London, Trans. 4: 17.

A pate pusilla Fairmaire, 1850, Rev. Zool. (ser. 2) 2: 50-51.

Rhizopertha rufa Waterhouse, 18ss, Ann. and Mag. Nat. Hist. (ser. 6) 1: 349.

Many citations to the literature are listed, but only a few of the more important ones are given.

Elongate, cylindrical, three times as long as wide, strongly shining. uniformly dark reddish brown to brownish black, sometimes with legs, antennae and palpi slightly paler.

Head transversely depressed behind clypeus; vertex smooth, glabrous, shining; clypeus and labrum coarsely, shallowly punctate, sparsely clothed with short, semierect, yellowish hairs. Antennal funicle with a few erect hairs; antennal club densely clothed with short, recumbent, yellowish hairs.

Pronotum strongly, uniformly convex, widest near middle, broadly rounded at apical and posterior angles; anterior margin strongly rounded; base truncate; sides broadly rounded, slightly margined near posterior angles; surface sparsely clothed with short, recumbent, inconspicuous hairs, anterior half with transversely arcuate rows of obtusely rounded teeth, those near anterior margin forming a strongly elerated, crenulate ridge, posterior half with large flattened granules.

Elytra at base subequal in width to pronotum near middle; sides parallel, conjointly rounded at apices; surface sparsely clothed with short, semierect, arcuate, yellowish hairs, and with rows of coarse. rather deep punctures, which are as wide as the intervals, and more or less confluent on apical declivity.

Body beneath rery sparsely clothed with short, recumbent, yellowish hairs; abdomen sparsely, coarsely, shallowly punctate, last sternite broadly rounded at apex; prosternum and mesosternum finely, densely granulose.

Length 2-3 mm., width $0.6-1 \mathrm{~mm}$.

Type locatities.-Of dominica, "America meridionali." Of pusilla, "India orientali." Of piceus, East Indies. Of fissicornis, England. Of mifa. Canton. China. The present locations of the types of dominica and pusitla are unknown to the writer, but the types of piceus, fissicornis, and mufa are supposed to be in the British Museum.

Distribution.-This cosmopolitan species has been distributed by commerce to all parts of the world. In the United States it will be found wherever regetable and grain products are stored. The original home of Rhyzopertha dominica is uncertain, but is probably India or the Malayan Region, as this area is considered to be the focus of a large number of species of Bostrichidae.

Hosts.- Rhyzopertha dominica is a pest of all kinds of stored grains and of a wide variety of foods, chiefly cereals. Its habit of feeding on stored grains and similar starchy products has rendered it of great economic importance. This species has been reported feeding on grains, including wheat, barley, rice, maize, millet, oats, sorghum, and ground products of these grains, and on chick peas, edible bulbs, white lotus seeds, banana products, lentils, beans, army and ship biscuits. stored drugs, dried potatoes, manioc, tapioca, arrow and turkey roots, cork in insect boxes, and wood of casks. 
Beeson and Bhatia (1937) report adults reared in India from logs of Abies webbiana. Alnus nitida, Artocarpus hirsuta, Bauhinia variegata, Buchanania latifolia, Dalbergia sissoo, Dendrocalamus strictus, Garugo pinnata, Heritiera formes, Mallotus philippinensis, Shorea robusta, Sterculia campanulata, Terminalia tomentosa, Thespesia populnea, and bamboo. Potter (1935) considers that this species originally fed solely on wood, probably living wood.

\section{Genus PROSTEPHANUS Lesne}

Prostephanus Lesne, 1898, Soc. Ent. de France Ann. (1897) 66: 320, 342-344; 1938, in Junk (pub.), Coleopt, Cat., pt. 161, p. 22.

Head strongly convex, partially covered by prothorax, not visible from above, the front not produced into a lobe on each side of clypeus, transversely depressed behind eyes, glabrous and shining on vertex; clypeus strongly transverse, broadly, arcuately emarginate in front, at sides as long as or longer than labrum; labrum subtruncate or broadly rounded and ciliate in front; mentum long, transverse, strongly lobed in front at middle; maxillary and labial palpi subequal in length, densely pubescent, apical segment of maxillary palpus elongate, acute at apex, apical segment of labial palpus oblong, narrowly rounded at apex; mandibles robust, acute at apices, with a small tooth at middle of inner and outer margins; eyes strongly projecting, oblong, transverse. Antenna 10-segmented; funicle slender, sparsely clothed with long hairs; first and second segments robust, subequal in length; third and fourth elongate; fifth to seventh shorter and slightly wider; eighth to tenth segments forming a broad, loose club, the segments subequal in length, and the tenth segment as wide as or wider than ninth. Pronotum globose, length and width subequal, ogival in front, tuberculate anteriorly, imbricate posteriorly; sides rounded posteriorly, obliquely narrowed anteriorly, and not distinctly margined, sometimes the margin indicated posteriorly by a row of small tubercles. Scutellum small, quadrate. Elytra strongly convex, punctate, abruptly declivous posteriorly, the declivity strongly margined on each side posteriorly, sometimes with distinct tubercles. Legs short, subequal in length; tibiae slightly expanded toward apices, dentate on exterior margins, anterior pair with large arcuate spine at apices, posterior tarsi shorter than tibiae, apical segment of each as long as the preceding four segments united. Anterior and middle coxae contiguous. Body elongate, three times as long as wide, cylindrical.

Genotype.-Apate punctatus Say. (Present designation.)

Lesne erected this genus for Dinoderus truncatus Horn and Apate punctatus Say, both from North America, and Xylopertha sulcicollis Fairmaire and Germain from Chile, without designating any of the species as the genotype.

\section{KEY TO THE SPECIES OF PROSTEPHANUS}

1. Apical declivity of elytra tuberculate

Apical declivity of elytra not tuberculate

2. Apical declivity of elytra with one or two short, straight, more or less distinct tubercles on each side, the surface with long, recumbent hairs...

Apical declivity of elytra with a large recurved tubercle on each side, the surface with short, inconspicuous, erect hairs arizonicus, new species pp. 38. 
3. Hairs on elytra short, recurved, on anterior part of disk about as long as the intervals between punctures; lateral margins of pronotum with a row of distinct teeth near posterior angles_- truncatus (Horn), p. 39.

Hairs on elytra long, recurved, on anterior part of disk at least twice as long as the intervals between punctures; lateral margins of pronotum without, or at most with a row of indistinct teeth near posterior angles........ apax Lesne, p. 40.

Prostephanus punctatus (Say)

Apate punctatus Melsheimer, (1806), Catalogue of the Insects of Pennsylvania, p. 7 (nomen nudum) ; Say, 1826, Acad. Nat. Sci. Phila. Jour. 5: 258-259.

Dinoderus punctatus Horn, 187s, Amer. Phil. Soc. Proc. 17: 549, 550; Gorham, 18s3, Biol. Centr.-Amer., Coleopt., 3, pt. 2:217; 1886, 3 (2) : 353 ; Packard, 1890, U. S. Ent. Commr., Rpt. 万, p. 223 (Insects Injurious to Forest and Shade Trees) ; Casey, 1S:98, N. Y. Ent. Soc. Jour. 6: 76 ; Blatchley, 1910, Coleoptera of Indiana, p. 890 ; Chittenden, 1911, U. S. Dept. Agr. Bur. Ent. Bul. 96, pt. 3, p. 49.

Stephanopachys punctatus Lesne, 1896, Soc. Ent. de France 65, pl. 8, fig. 13 ; Leon ard, 1928, N. Y. (Cornell) Agr. Expt. Stat. Mem. 101:415; Brimley, 1938, Insects of North Carolina, p. 198.

Prostcphanus punctatus Lesne, 1898, Soc. Ent. de France Ann. (1S97) 66: 342, 343-344; 1938, in Junk (pub.), Coleopt. Cat., pt. 161, p. 22.

Dark reddish brown to brownish black, the palpi, antemnae, and legs paler.

Head with front coarsely, irregularly punctate, sparsely clothed with long, inconspicuous, semierect hairs, obliquely deflexed at anterior margin; clypeus flat, coarsely, shallowly punctate, sparsely clothed with long, inconspicuous, semierect hairs, with two to six small, more or less distinct, tubercles along anterior margin. Antemnal club densely clothed with short, recumbent, yellowish hairs, with a few long, erect hairs intermixed, the segments transverse, oval.

Pronotum strongly, uniformly convex. widest near basal third, with a vague, longitudinal groove at middle of disk; sides with a row of small teeth on each side near posterior angles; surface sparsely clothed with short, inconspicuous, recumbent hairs, densely. coarsely punctate at sides, coarsely imbricate at middle on basal half, the imbrications broad and broadly rounded at apices, and with transversely arcuate rows of elerated teeth at middle on apical half, the teeth obtusely rounded at apices and distinctly separated from one another, except the two median ones on anterior margin, which are nearly contiguous.

Elytra at base subequal in width to pronotum near basal third; sides parallel, conjointly, broadly rounded at apices; surface coarsely, densely, irregularly punctate, sparsely clothed with short, recurved, yellowish hairs, which are about as long as intervals between the punctures on anterior part of disk: apical declivity rather densely clothed with long, recumbent, yellowish hairs, with one or two more or less distinct, small, erect tubercles on each side near top of declivity. densely, coarsely. confluently punctate in females, nearly smooth and finely, sparsely punctate along sutural margins in males.

Body beneath sparsely clothed with long, recumbent. yellowish hairs; abdomen finely, indistinctly punctate, and finely, densely granulose.

Length 4-5 mm., width $1.5-1.7 \mathrm{~mm}$.

Type locality.-None given, but probably York County, Pa.

Since the type of this species is lost. the writer is designating a specimen in the United States National Museum, collected at Frankford. Pa., July 9, by A. Schmidt, as the neotype. 
Distribution.-This species is widely distributed over the eastern half of the United States. Specimens have been examined from the District of Columbia, Florida, Georgia, Illinois, Iowa, Kansas, Maryland, Massachusetts, New Jersey, New York, North Carolina, Pennsylvania, South Carolina, Texas, and Virginia. Gorham (1883, 1886) lists it from Guatemala, Nicaragua, and Mexico, but it is possible that it is a misidentification for truncatus Horn, which is very common in Mexico and Central America.

Hosts.-This species has been reared from oak in North Carolina and pecan in Georgia. Chittenden (1911) stated that this species appears to confine itself to dead roots and stumps, and, so far as known, has not attracted any attention by its presence indoors.

Melsheimer (1806) listed this species in his Catalogue of the Insects of Pennsylvania without giving any description, but probably it was collected in York County or near Philadelphia. Say (1826) described the species without giving any locality, but citing the Melsheimer Catalogue.

The tubercles on the apical declivity of the elytra are variable in size and number. Usually there is a distinct tubercle on each elytron; sometimes there are two very close together on each elytron, rarely these are obsolete. The ones having the tubercles obsolete can be separated from truncatus in having long, recumbent hairs on the apical declivity. The sexes in this species can be easily separated by having the apical declivity of the elytra coarsely, uniformly punctate in the females and more or less smooth along the sutural margins in the males. The tubercles on the anterior margin of the clypeus are variable in number.

Prostephanus arizonicus, new species

Uniformly dark reddish brown, the palpi and antennae slightly paler.

Head with front densely, deeply, irregularly punctate, sparsely clothed with short, inconspicuous, semierect hairs, abruptly deflexed at anterior margin; clypeus flat, densely, shallowly punctate, sparsely clothed with short, inconspicuous, erect hairs, with six vague, obtuse tubercles along anterior margin. Antennal club densely clothed with short, recumbent, yellowish hairs, with a few long, erect hairs intermixed, the segments transverse, oval.

Pronotum strongly, uniformly convex, widest at basal third, with a distinct longitudinal groove at middle of disk; sides with a row of small teeth on each side near posterior angles; surface sparsely clothed with short, inconspicuous, recumbent hairs, coarsely, rather densely punctate at sides, smooth and sparsely punctate at middle of disk, coarsely, vaguely imbricate in front of scutellum, the imbrications broad and broadly rounded at apices, and with transversely arcuate rows of elevated teeth at middle on apical half, the teeth obtusely rounded at apices and distinctly separated from one another, except the two median ones on anterior margin, which are nearly contiguous.

Elytra at base subequal in width to pronotum at basal third; sides parallel, conjointly broadly rounded at apices; surface rather coarsely, densely, irregularly punctate, sparsely clothed with short, recurved, yellowish hairs, which are about as long as the intervals between punctures on anterior part of disk; apical declivity sparsely, coarsely 
punctate, the punctures more distant along sutural margins, sparsely clothed with short, inconspicuous, erect hairs, and with a large, recurved tubercle on each side near middle of declivity.

Body beneath sparsely clothed with rather long, recumbent, yellowish hairs; abdomen coarsely, shallowly punctate, and finely, densely granulose; prosternum rugose.

Length $6 \mathrm{~mm}$., width $2 \mathrm{~mm}$.

Type locality.-Care Creek Canyon, Chiricahua Mountains, Ariz.

Type and paratype.-In the United States National Museum, No. 58311 .

Described from two specimens (one type). The type (probably a male) was collected at light, July 4, 1897, by H. G. Hubbard, and the paratype was collected at Douglas, Chiricahua Mountains, Ariz., August 7,1938 , by W. Tr. Jones.

This species is closely allied to punctatus (Say), but it differs from it and all the other known species of this genus in being larger, and in having a large recurved tubercle on each side of the apical declivity of the elytra.

\section{Prostephanus truncatus (Horn)}

Dinoderus truncatus Horn. 187s, Amer. Phil. Soc. Proc. 17: 549, 550; Rilev, 1894, Insect Life 6: 219; Chittenden, 1895, Insect Life $7: 327 ; 1896$, U. S. Dept. Agr. Dir. Ent. Tech. Ser. 4, p. 28: Casey, 189s. N. Y. Ent. Soc. Jour. 6: 76 ; Chittenden, 1911, U. S. Dept. Agr. Bur. Ent. Bul. 96, pt. 1, pp. 1, 4, 9; ibid. 96, pt. 3, pp. 48-52, figs. 9-10 ; Back, 1919, U. S. Dept. Agr. Farmers' Bul. 1029 ; pp. 21-23, fig. 15; Back and Cotton, 1922, U. S. Dept. Aפr. Farmers' Bul. 1260 , p. 13, figs. $13-14$; 1930 (rerised), pp. 9-11, fig. 13; Back, 1931, U.S. Dept. Agr. Farmer's' Bul. 1029 (rerised), pp. 17-19, fig. 15.

Stephanopachys truncatus Back and Cotton, 1940, U. S. Dept. Agr. Farmers' Bul. 1260 (revised), pp. 7-8, figs. 8-9.

Prostephanus truncatus Lesne, 1898. Soc. Ent. de France Ann. (1897) 66: 342, 3ı3, figs. 1 b, 25, 26; 193s, in Junk (pub.), Coleopt. Cat., pt. 131, p. 22 ; 1939 ; Rer. Franç. d'Ent. 6: 91, 92-93.

Pale reddish brown to brownish black, the palpi, antennae, and legs paler.

Head with front finely, sparsely punctate, sparsely clothed with long, inconspicuous, semierect hairs, narrowly, abruptly deflexed at anterior margin: clypeus flat, densely, coarsely punctate, sparsely clothed with long, inconspicuous, semierect hairs, with two small tubercles at middle along anterior margin. Antennal club densely clothed with short, recumbent, yellowish hairs, with a few long. erect hairs intermixed. the first segment transverse, oval, second subtriangular, and third oblong.

Pronotum strongly, uniformly convex, widest near basal fourth, without a distinct, longitudinal groove at middle of disk; sides with a row of small teeth on each side along lateral margin; surface sparsely clothed with short, inconspicuous, recumbent hairs. densely, coarsely punctate at sides, coarsely imbricate at middle on basal half. the imbrications narrow and narrowly rounded anteriorly, and with transversely arcuate rows of elevated teeth at middle on apical half. the teeth obtusely rounded at apices and distinctly separated from one another (the two median ones on anterior margin nearly contiguous).

Elytra at base as wide as pronotum at basal fourth: sides parallel. conjointly broadly rounded at apices; surface coarsely; densely punc- 
tate, the punctures arranged in more or less distinct rows, sparsely clothed with short, recurved, yellowish hairs, which are about as long as the intervals between the punctures on anterior part of disk; apical declivity sparsely clothed with short, erect, yellowish hairs, without tubercles, densely, coarsely, irregularly punctate and granulose on the intervals in both sexes.

Body beneath sparsely clothed with rather long, recumbent, yellowish hairs; abdomen finely, indistinctly punctate and finely, densely granulose.

Length 3-4.5 mm., width 1-1.5 mm.

Type Tocality.-California, no definite locality; type in the Horn Collection, in the Academy of Natural Sciences of Philadelphia.

Distribution.-This species seems to be restricted to the warmer parts of North America. It has been recorded from various places in Mexico, Guatemala, Nicaragua, Costa Rica, and from Cape San Lucas, Lower California. It has been intercepted at Brooklyn, N. Y.; Hoboken, N. J.; Nogales, Ariz.; El Paso and Laredo, Tex.; Live Oak and San Francisco, Calif; and Jefferson City, Mo., in corn and wooden ornaments from Mexico. Back and Cotton (1922) state that this tropical beetle, not as yet widely distributed in the United States, is occasionally found infesting corn in the Southern States. Probably it has acquired the grain-feeding habit recently.

Horn (1878) described the species from two mutilated specimens from California. Riley (1894) under the name of Dinoderus sp. reported it as living in grain and edible tubers from Mexico at the World's Columbian Exposition. Chittenden (1896) recorded it in corn from Mexico at the New Orleans Exposition and also in Mexican seed corn in the Botanical Division of the United States Department of Agriculture. It is able to subsist on almost any kind of roots and tubers, and would cause great damage if it should become generally established in the granaries, as the adults have the habit of leaving the grain and boring into the wood, and have been known to bore into both pine and black walnut. Lesne (1898) recorded a single specimen taken at Rouen in Salsepareille, a plant of the genus Smilax imported from Central America. Chittenden (1911) stated that this species seems to prefer corn, especially corn on the ear, and that tubers and roots serve as a natural breeding place.

\section{Prostephanus apax Lesne}

Prostephanus apax Lesne, 1930, Soc. Ent. de France Bul., pp. 102-103; 1938, in Junk (pub.), Coleopt. Cat., pt. 161. p. 22.

Reddish brown to brownish black, the palpi, antennae, and legs paler.

Head with front finely, densely punctate, smooth along anterior margin, sparsely clothed with long, inconspicuous, semierect hairs, feebly. obliquely deflexed at anterior margin; clypeus flat, finely, densely punctate posteriorly, sparsely clothed with long, inconspicucus, semierect hairs, with two small distinct tubercles at middle along anterior margin. Antennal club densely clothed with short, recumbent, yellowish hairs, with a few long, erect hairs intermixed, the first and second segments transverse, subtriangular, and third oblong.

Pronotum strongly, uniformly convex, widest near basal third, without a distinct, longitudinal groove at middle of disk; sides with- 
out a distinct row of teeth along lateral margins; surface sparsely clothed with long, recumbent yellowish hairs, sparsely, rather densely punctate at sides, coarsely imbricate at middle on basal half, the imbrications narrow and narrowly rounded at apices, and with transversely arcuate rows of elevated teeth at middle on apical half, the teeth obtusely rounded at apices, and distinctly separated from one another, except the two median ones on anterior margin, which are nearly contiguous.

Elytra at base subequal in width to pronotum at basal third; sides parallel, conjointly broadly rounded at apices: surface rather coarsely, densely punctate, the punctures arranged in more or less distinct rows, sparsely clothed with long, recurved. yellowish hairs, which are twice as long as the intervals between punctures on anterior part of disk; apical declivity sparsely clothed with short, erect, yellowish hairs, without tubercles, coarsely, sparsely. irregularly punctate and distinctly granulose in both sexes.

Body beneath sparsely clothed with rather long, recumbent, yellowish hairs; abdomen sparsely, shallowly punctate, and finely. densely granulose.

Length 3-5 mm., width $1-1.6 \mathrm{~mm}$.

Type Tocality.-Santa Rita Mountains, Ariz.; type in Paris Museum.

\section{Distribution.-From material examined :}

Arizova : Santa Rita Mountains, 3,000 to 4,000 feet, June 15, 1924 (C. T. Vorhies); Stone Cabin Canyon, Santa Rita Mountains, August 25, 1913 (W. D. Pierce) ; French Creek (E. A. Schwarz), Sabino Canyon, Santa Catalina Mountains, November 28, 1913, reared (H. S. Barber); Fish ('reek, 2,300 to 3,000 feet, December 16, 1913, reared (Schwarz and Barber).

Caxal ZoNe: Paraiso, February 11, 1911 (E. A. Schwarz) ; Panama, December 1911 (A. Busck).

MExico: Hacienda Hormiguera, Torrion, Coahuila, April 10, 1922 (Hunter No. 9099).

Host. - All the specimens examined from Arizona were reared from or collected on wild cotton (Thurberia thespesioides Gray). A nice series of specimens was reared from dead twigs of this plant by $\mathrm{H}$. S. Barber and E. A. Schwarz. One specimen was taken in a dry stem of cultivated cotton in Mexico.

Lesne (1930) described this species from two specimens collected by C. T. Vorhies, and specimens have been examined by the writer from the original set. This is a valid species, but many of the characters given by Lesne to distinguish it from truncatus are found to be variable when a good series of specimens are available for study. In a large series of specimens of apar and truncatrs examined from Arizona, Mexico, and Central America, the body of apax is not more elongate, the sculpture on the pronotum and elytra are not more distinctly sparser or shallower, the last segment of the antenna is not narrower. and the cuneiform tubercles near the posterior margin of the pronotum are not more elongate than in truncatus. In truncatus the lateral margins of the pronotum near the posterior angles are marked with a row of distinct teeth, whereas in apar these are absent or at the most only vaguely indicated. In truncatus the hairs on the elytra are short and recurved. and on the anterior part of the disk are about as long as the intervals between the punctures, whereas in apax the hairs are considerably longer, at least twice as long as the intervals, but in both 
species the hairs are proportionately longer toward the lateral margins.

\section{Genus STEPHANOPACHYS Waterhouse}

Stephanopachys Waterhouse, 18s8, Ann. and Mag. Nat. Hist. (ser. 6) 1: 349 ; Zoufal, 1894, Wien, Ent. Ztg. 13: 35, 42 ; Bedel, 1894, Abeille 28: 149-150; Lesne, 1898, Soc. Ent. de France Ann. (1897) 66:320, 333-342 ; Schilsky, 1899, in Küster and Kraatz, Käfer Europas, 36 : pp. tt, ww-xx ; Everts, 1901, Coleopt. Neerlandica, v. 2, pp. 209, 211; Lesne, 1901, Abeille 30:78, 81-84, pl. 1, fig. 13; Reitter, 1911, Fauna Germanica, v. 3, pp. 301, 303, fig. 110; Jakobson, 1913, Käfer Russland, pt. 10, pp. 802-803; Lesne, 1938, in Junk (pub.), Coleopt. Cat., pt. 161, pp. 20-22.

Dinoderus Guérin-Ménérille, 1945, Soc. Ent. de France Ann. (ser. 2), г. 3, Bul. p. Xvii ; Lacordaire, 1857, Genera des Coléopt., vol. 4, pp. 534, 540; Redtenbacher, 1858, Fauna Austriaca Käfer, ed. 2, pp. CI, 569 ; Jacquelin-Dural, 18591863, Genera Coléopt. Europe, v. 3, pp. 230-231, 233, pl. 56, fig. 280; LeConte, 1861, Smithsn. Inst. Misc. Collect. 3 (1) : 208; Thompson, 1863, Skandinaviens Coleopt., v. 5, pp. 202-203; Redtenbacher, 1874, Fauna Austriaca Käfer, ed. 3, pt. 1, p. CXII, pt. 2, p. 65 ; Kiesenwetter, 1877, in Erichson, Nat. Ins. Deutsch. Coleopt., v. 5, pt. 1, pp. 28-31; Horn, 1878, Amer. Phil. Soc. Proc. 17: 541, 548 (part) ; Seidlitz, 1889, Fauna Baltica, Kaefer, pp. 117, 496 ; 1889, Fauna Transsylvanica, Kaefer, pp. 117, 530; Casey, 1898, N. Y. Ent. Soc. Jour. 6: 66, 73-76 (part).

Head strongly convex, partially covered by prothorax, not visible from above, the front not produced into a lobe on each side of clypeus, transversely depressed behind eyes, glabrous and shining on vertex; clypeus strongly transverse, broadly, arcuately emarginate in front, at sides as long as, or longer than labrum; labrum subtruncate and ciliate in front; mentum long, strongly transverse, truncate or vaguely lobed in front; maxillary palpi slightly longer than labial palpi, apical segments of all palpi oblong, acute or rounded at apices; mandibles robust, feebly toothed on inner margins toward apices; eyes strongly projecting, oblong, transverse. Antenna short, 10-segmented, funicle robust, with short hairs; first and second segments robust, subequal in length; third to seventh slightly narrower, subequal in length to one another, becoming gradually wider and more transverse toward seventh segment; last three segments forming a broad, loose club, the eighth and ninth segments oblong, transverse, the tenth oval and narrower than ninth. Pronotum globose, subequal in length and width, broadly rounded in front, tuberculate anteriorly, granulose posteriorly; sides rounded but not margined. Scutellum very small, quadrate. Elytra strongly convex, regularly declivous posteriorly; sides parallel, broadly conjointly rounded at apices; surface punctate, scabrous or granulose. Legs short, subequal in length; tibiae slender, scarcely expanded toward apices, dentate on exterior margins, anterior pair with an arcuate spine at apices; posterior tarsi shorter than tibiae, apical segment of each as long as preceding four segments united. Anterior coxae contiguous. Middle coxae contiguous or narrowly separated. Last visible abdominal sternite with a deep, transverse fovea on each side in male, without the fovea in female. Body elongate, cylindrical.

Genotype.-A pate substriatus Paykull. (Monobasic.)

Waterhouse (1888) proposed Stephanopachys for Apate substriatus Paykull, not Dinoderus substriatus Stephens, with a note stating that the species is too well known to require a further description. The genus includes 16 species, one of which is here described as new. 
All the species are widely distributed throughout the northern parts of Europe, Asia, and North America, except quadricollis Marseul, which is restricted to the Mediterranean region. Only 9 of the species occur in North America.

\section{KEY TO THE SPECIES OF STEPHANOPACHYS}

1. Pronotum with strongly elevated granules on basal half ............

2. Elytra with longitudinal rows of elevated granules on intervals on basal half of disk, each granule with a short, erect hair arising from the apex

Elytra without distinct rows of elevated granules on intervals on basal half of disk, the intervals smooth, or with irregular shaped granules, each with a short hair arising from the side.......................

3. Granules on basal half of disk of elytra beadlike, each with a round depression at apex; apical declivity of elytra with strongly elevated

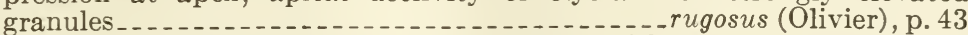

Granules on basal half of disk of elytra conical, without a round depression at apices; apical declivity of elytra with moderately elevated granules

4. Apical declivity of elytra granulose; lateral margins of pronotum strongly tuberculate

Apical declivity of elytra punctate; lateral margins of pronotum slightly serrulate ...

5. Hairs on basal half of disk of elytra short and recumbent

substriatus (Paykull), p. 45.

Hairs on basal half of disk of elytra short and erect_asperulus (Casey), p. 47.

6. Pronotum slightly gibbose in front of scutellum; hairs on basal half of disk of elytra long, not uniform in length, the long ones at least twice as long as diameter of punctures; mentum subtruncate in front

sobrinus (Casey), p. 47.

Pronotum not gibbose in front of scutellum; hairs on basal half of disk of elytra short, uniform in length, about as long as diameter of punctures; mentum feebly lobed...............conicola, new species, p. 48.

7. Apical declivity of elytra punctate; labrum irregularly, indistinctly punctate_...

Apical declivity of elytra granulose; labrum coarsely, uniformly punctate.-

8. Elytra smooth, with circular punctures; pronotum not gibbose in front of scutellum, the flattened granules contiguous in front of scutellum, and the teeth along anterior margin short, broadly rounded, not separated at bases (vide Casey) .................... densus (LeConte), p. 50.

Elytra granulose or scabrous; pronotum slightly gibbose in front of scutellum, flattened granules separated from one another, and the teeth along anterior margin long, acute, and separated at bases

hispidulus (Casey), p. 50.

\section{Stephanopachys RUgosus (Olivier)}

Bostrichus rugosus Olivier, 1795, Entomologie, v. 4, Gen. 7т, p. 18, pl. 3, figs. 24a-b. Stephanopachys rugosus Lesne, 1896, Soc. Ent. de France Bul., p. 334 ; 1898, Soc. Ent. de France Ann. (1897) 66: 335, 341-342 ; Leonard, 1928, N. Y. (Cornell) Agr. Expt. Sta. Mem. 101: 415; Brimley, 1938, Insects of North Carolina, p. 19s ; Lesne, 1938, in Junk (pub.), Coleopt. Cat., pt. 161, p. 21 ; Anderson, 1939, Wash. Acad. Sci. Jour. 29: 388, fig. 2 (larra).

Dinoderus porcatus LeConte, 1866, Smithsn. Inst. Misc. Collect. 167: 101-102; Horn, 1878, Amer. Phil. Soc. Proc. 17: 548, 549 ; Casey, 1898, N. Y. Ent. Soc. Jour. 6: 75; Blatchley, 1910, Coleoptera of Indiana, p. s90; Lesne, 1935, in Junk (pub.), Coleopt. Cat., pt. 161, p. 21.

Dinoderus opacus Casey, 1898, N. Y. Ent. Soc. Jour. $6: 75$ (new synonymy).

Stephanopachys opacus Lesne, 1938, in Junk (pub.), Coleopt. Cat., pt. 161, p. 21.

Pale reddish brown to brownish black, the palpi and antemnae sometimes slightly paler.

Head with front and clypeus sparsely, coarsely granulose, sparsely clothed with rather long, arcuate, semierect, yellowish hairs; mentum subtruncate in front. 
Pronotum strongly, uniformly convex, widest near middle; sides broadly rounded, coarsely tuberculate along entire margin; surface sparsely clothed on disk with short, semierect hairs, and at sides with long, erect hairs, densely, coarsely granulose, the granules on basal half strongly elevated and distinctly separated from one another, apical half with numerous broad, strongly elevated teeth, which are longer, acute at apices, and separated at bases from one another along anterior margin.

Elytra at base slightly wider than pronotum near middle; surface with longitudinal rows of coarse ptinctures on disk, the rows confused at sides and sometimes along sutural margins, the punctures about as wide as intervals, rather densely clothed at sides and on apical declivity with long, erect, yellowish hairs, intervals on basal half of disk with distinct rows of elevated, beadlike granules, each with a round depression at apex, from which arises a short, erect hair; apical declivity with strongly elevated, irregularly distributed granules.

Abdomen beneath rather coarsely, densely punctate, sparsely clothed with short, recumbent, yellowish hairs.

Length $2.5-4.5 \mathrm{~mm}$., width $1-1.5 \mathrm{~mm}$.

Type localities.-Of rugosus, Amérique Septentrionale; type in the Bosc Collection, supposed to be in the Paris Museum. Of porcatus, Atlantic States; type in the LeConte Collection in the Museum of Comparative Zoology. Of opacus, Norfolk, Va.; type in the Casey Collection in the United States National Museum.

Distribution.-Material has been examined from Alabama, District of Columbia, Florida, Georgia, Indiana, Louisiana, Maryland, Mississippi, Missouri, New York, North Carolina, Ohio, Oklahoma, Pennsylvania, South Carolina, Texas, Virginia, and West Virginia. Adults have been intercepted at Capetown, Africa, in pitch pine shipped from New Orleans, La.

Hosts.-This species is found boring in the bark and wood of various species of pines. At times it does considerable damage to flooring and other timbers in buildings, and has been reported as boring in cypress sheathing on a house in Louisiana.

Olivier (1795) described migosus from the Bosc Collection, placing it in the genus Bostrichus. LeConte (1866) described Dinoderus porcatus, stating that it was common in the Atlantic States, without giving any definite locality. Casey (1898) described Dinoderus opacus from six specimens collected at Norfolk, Va., placing them with the species having the elytra opaque. When these types were examined, they were found to be dirty specimens of rugosus; the cleaned surface was shiny and the graules were as well defined as in rugosus. Casey did not have rugosus Oliver represented in his collection.

\section{Stephanopachys amplus (Casey)}

Dinoderus amplus Casey, 1898, N. Y. Ent. Soc. Jour. 6: 74-75.

Stephanopachys amplus Lesne, 1938, in Junk (pub.), Coleopt. Cat., pt. 161, p. 20.

Uniformly reddish brown, the palpi, antennal club, and tarsi slightly paler.

Head with front and clypeus coarsely, sparsely granulose, sparsely clothed with rather long, arcuate, semierect, yellowish hairs, the clypeus glabrous and smooth along anterior margin; mentum subtruncate in front. 
Pronotum strongly convex, slightly gibbose in front of scuttelum, widest near middle; sides broadly rounded, coarsely tuberculate alon:r margins; surface sparsely clothed with short, inconspicuous, recumbent hairs on disk, the hairs longer and more erect toward sides, densely, coarsely granulose, the granules on basal half strongly elerated and distinctly separated from one another, apical half with numerous broad, strongly elevated teeth, which are longer, acute at apices, and separated at bases from one another along anterior margin.

Elytra at base slightly wider than pronotum near middle; surface with longitudinal rows of coarse punctures on disk, the rows confused at sides and sometimes along sutural margins, punctures about as wide as intervals, rather densely clothed at sides and on apical declivity with long, erect, rellowish hairs, intervals on basal half of disk with distinct rows of elevated, conical granules, without a round depression at apices, but from which arises a short, erect hair; apical declivity with moderately elerated, irregularly distributed granules.

Abdomen beneath sparsely. shallowly punctate, sparsely clothed with long, recumbent. vellowish hairs.

Length $3.5-4 \mathrm{~mm}$.. width $1.3-1.5 \mathrm{~mm}$.

Type locality.-Seligman, Ariz. Type in the Casey Collection in the United States National Museum.

This species was described from a single specimen. The depressions on the type are obscured by dirt, and if it were cleaned, the entire surface would be polished.

\section{Stepha.opachys SUbStRiatus (Paykull)}

Apate substrictus Paykull, 1800, Fauna Suecica, r. 3, pp. 142-143 ; Gyllenhal, 1s13, Insecta Suecica, .. 1, pt. 3, p. 374; Zetterstedt, 1S2S, Fauna Ins. Lapponica, Г. 1, p. 349 ; 1840 , Ins. Lapponica, $\nabla .1$, p. 194; Redtenbacher, $1547-1549$, Fauna Austriaca, Die Käfer, p. 3ذt; Bach, 1552, Käferfauna für Nord und Mitteldeutschland, г. 2, pp. 117-11s.

Dinoderus substriatus Stephens, 1S30, Illus. Brit. Ent., Mandibulata, r. 3, pp. 352-353; Spr.y and Shuckard, 1S40, Brit. Coleopt., p. 44, pl. 53, fig. 5; Mannerheim, 1553, Mioscow Soc. Imp. Nat. Bul. 26 (2) : 233-234 (separate pp. 141-142) ; Redtenbacher, 18.j, Fauna Austriaca, Die Käfer, ed. 2, p. .69; Jacquelin-Dural, 1859-1863, Genera Coleopt. Europs, r. 3, pp. 230-2:31, pl. 56, fig. 280 ; Kiesenwetter, 1577, in Elichson, Nat. Ins. Deutschl. Coleopt., v. 5, pt. 1, p. 30: Horn, 1878, Amer. Phil. Soc. Proc. 17: 548, 549; Gorham. 1S83, Biol. Centr.-Amer., Coleopt., v. 3, pt. 2, p. 218; $18 \$ 6$ iもid., p. 353; Fowler, 1890, Coleopt. Brit. Isl., r. 4. p. 200. pl. 11S, fig. 13: Caser, 1S98, N. Y. Ent. soc. Jour. 6: 73: Burgess, 1899, U. S. Dept. Agr., Dir. Ent., Bul. 20, pp. 107-10s; Blatchley, 1910, Culeoptera of Indiana, pp. 890 , S91; Hopkins, 1915, Jour. Econ. Ent. 8: 388.

Stephanopachys substriatus Waterhouse, 188s, Ann. and Mag. Nat. Hist. (ser. 6) 1: 349 ; Bedel, 1S94, Abeille 28: 150; Lesne, 1S9S, Soc. Ent. de France Ann. (1897) 66: 334, 337-339; Donisthorpe, 1900, Ent. Rec. and Jour. Variation 12: 16-18; Lesne, 1901, Abeille 30 : 82, 83; 1902, ibid. 30 : 124-125; Reitter, 1911, Fauna Germanica, . 3, p. 303 ; Leonard, 192S, N. Y. (Cornell) Agr. Expt. Sta. Mem. 101: 415; Brimles, 1938, Insects of North Carolina, p. 19S; Lesne, 193s, in Junk (pub.), Coleopt. Cat., pt. 161, pp. 21-22 ; Anderson, 1939, Wash. Acad. Sci. Jour. 29: 388, figs. 1, 4, 7, 8, 11, 21 (larvae).

Dinoderus pacificus Casey, 1898, N. Y. Ent. Soc. Jour. 6: 73-74 (new synonymy). Stephanopachys pacificus Böring and Craighead, 1931, Ent. Amer. (n. s.) 11: 62, pl. 102, fig. A (larrae) ; Lesne, 1938, in Junk (pub.), Coleopt. Cat., pt. 161, p. 21 ; Anderson, 1939, Wash. Acad. Sci. Jour. 29: 3S8, figs. 9-10 (larvae).

There are many citations to this species in the literature, but only a few of the more important ones have been given.

Uniformly brownish black, sometimes black with a rague brownish tinge, the antennae, palpi, and legs reddish brown. 
Head with front and clypeus sparsely, coarsely granulose, sparsely clothed with rather long, arcuate semierect hairs, the clypeus glabrous and smooth along anterior margin; mentum subtruncate in front.

Pronotum strongly, uniformly convex, widest near middle; sides broadly rounded, coarsely tuberculate along margins; surface sparsely clothed with short, recumbent, yellowish hairs on disk, the hairs longer and more erect at sides, densely, coarsely granulose, the granules on basal half strongly elevated, and distinctly separated from one another, apical half with numerous broad, strongly elevated teeth, which are longer, acutely rounded at apices, and usually separated from one another at bases along anterior margin.

Elytra at base slightly wider than pronotum near middle; surface coarsely, densely, irregularly punctate, the punctures on disk about as wide as intervals, rather densely clothed at sides and on apical declivity with long, erect, yellowish hairs, intervals on basal half of disk scabrous, without distinct rows of elevated, beadlike granules, but with irregular shaped granules, each with a short yellowish hair arising from its side and curved over the puncture; apical declivity distinctly, coarsely, irregularly granulose.

Abdomen beneath sparsely, coarsely, shallowly punctate, sparsely clothed with long, recumbent, yellowish hairs.

Length $3.5-6.5 \mathrm{~mm}$., width $1-2.25 \mathrm{~mm}$.

Type locality.-Of substriatus, Provinces of Westrogothia and Scania, Sweden; types supposed to be in the Museum at Stockholm. Of pacificus, Mokel Hill, Calif.; type in the Casey Collection in the United States National Museum.

Distribution.-This species is widely distributed throughout the northern parts of the world. Lesne (1901) stated that this boreal species is found throughout the Scandinavian countries, northern Europe, and Russia, extending southward in the mountains to the Carpathians and Alps of Transsylvania, across Siberia and into Alaska, Canada, and the United States. Material has been examined from Canada and nearly all the States in the northern half of the United States. The localities given by Gorham $(1883,1886)$ are probably from erroneously identified specimens.

Hosts.-This species attacks Douglas-fir (Pseudotsuga taxifolia), hemlock (Tsuga canadensis), and all species of pines and firs (Pinus spp. and Abies spp.). In Europe Pinus sylvestris is especially susceptible to its attacks. Lesne (1901) recorded it attacking pine bark used for tanning. Burgess (1899) recorded this species as doing severe injury to hemlock tan bark in Massachusetts, and Hopkins (1915) reported the beetles in West Virginia as only attacking hemlock tan bark after it is 2 or 3 years old. This species has been reported a number of times as damaging furniture and lumber used in the consiruction of buildings.

Casey (1898) described Dinoderus pacificus from seven specimens. The type and one paratype are from Mokel Hill, Calif., two paratypes from California, and one from Colorado without definite localities, one from Placerville, Calif., and one from Coeur d'Alene, Idaho. After examining the above type and large series of substriatus from Europe and North America, the writer is unable to separate pacificus Casey from substriatus Paykull. 


\section{Stephanopachys asperulus (Casey)}

Dinoderus asperulus Casey, 1898, N. Y. Ent. Soc. Jour. 6: 74.

Stephanopachys asperulus Lesne, 1938, in Junk (pub.), Coleopt. Cat., pt. 161, p. 20.

Reddish brown to brownish black, the palpi, antennae, and legs more reddish.

Head with front and clypeus coarsely, sparsely granulose, sparsely clothed with rather long, semierect, yellowish hairs, the clypeus glabrous and smooth along anterior margin; mentum subtruncate in front.

Pronotum strongly convex, slightly gibbose in front of scutellum, widest at middle; sides broadly rounded, coarsely tuberculate along margins; surface sparsely clothed with short, inconspicuous, recumbent hairs on disk, the hairs longer and erect at sides, densely, coarsely granulose, the granules on basal half strongly elevated, and distinctly separated from one another, apical half with numerous broad, strongly elevated teeth, which are longer, acute at apices, and separated at bases from one another along anterior margin.

Elytra at base subequal in width to pronotum at middle; surface coarsely, densely, irregularly punctate, the punctures on disk as wide as intervals, rather densely clothed at sides and on apical declivity with long, erect, yellowish hairs, intervals on disk scabrous, without distinct rows of elevated, beadlike granules, but with irregular shaped granules, each with a short, erect hair arising from its side; apical declivity distinctly, rather coarsely, irregularly granulose.

Abdomen beneath coarsely, sparsely, shallowly punctate, sparsely clothed with rather short, recumbent, yellowish hairs.

Length $3-5 \mathrm{~mm}$., width 1-1.75 mm.

Type locality.-Fort Wingate, N. Mex. Type in the Casey Collection in the United States National Museum.

Distribution.-From material examined:

Arizona: Flagstaff, July (H. F. Wickham) (J. L. Webb). Chiricahua Mountains, June 8-14 (Hubbard and Schwarz); August 6 (J. L. Webb). Santa Catalina Mountains (J. L. Webb). Williams, May 29-June 6 (Barber and Schwarz).

New Mexico: Gallup (H. F. Wickham). Fort Wingate, type (Dr. Shufeldt).

Hosts.-J. L. Webb collected this species on Pinus ponderosa and $P$. strobiformis in Arizona.

Casey described this species from a unique specimen. The type, like most specimens in this genus, has the punctures filled with foreign matter, and therefore the surface appears to be subopaque, but the tops of the granules are clean and highly polished.

\section{Stephanopachys sobrinus (Casey)}

Dinoderus sobrinus Casey, 1898, N. Y. Ent. Soc. Jour. 6 : 74.

Stephanopachys sobrinus Lesne, 1938, in Junk (pub.), Coleopt. Cat., pt. 161, p. 21.

Uniformly brownish black, rarely reddish brown, the palpi, antennae, and legs more reddish brown.

Head with front and clypeus finely, rather densely, shallowly punctate, finely, densely granulose, sparsely clothed with long, erect hairs, the clypeus smooth and glabrous along anterior margin; mentum subtruncate in front.

Pronotum strongly convex, slightly gibbose in front of scutellum, widest at basal third; sides broadly rounded posteriorly, arcuately 
narrowed anteriorly, slightly serrulate along margins; surface sparsely clothed with short, erect hairs on disk, the hairs long toward sides and anterior margin, densely, coarsely granulose, the granules on basal half strongly elevated and distinctly separated from one another, apical half with a number of broad, short, strongly elevated teeth, which are broadly rounded at apices and widely separated along anterior margin.

Elytra at base subequal in width to pronotum at basal third; surface coarsely, densely, irregularly punctate, the punctures on disk not so wide as intervals, rather densely clothed with fine, long and short hairs intermixed, the long hairs on basal half of disk at least twice as long as diameter of punctures, intervals on disk smooth, without distinct granules; apical declivity coarsely, irregularly punctate.

Abdomen beneath coarsely, sparsely, shallowly punctate, sparsely clothed with moderately long, recumbent, yellowish hairs.

Length $2.75-4.5 \mathrm{~mm}$., width $1-1.5 \mathrm{~mm}$.

Type locality.-Laramie, Wyo.; type in the Casey Collection in the United States National Museum.

Distribution.-From material examined:

ArIzona : Flagstaff, July 7 (Barber and Schwarz) ; July 30, 1904 (J. L. Webb). Williams, July 24 (Barber and Schwarz); September 3, paratype, Winslow (H. F. Wickham). Palmerlee, Cochise County, July (Chas. Schaeffer). Bright Angel Camp, altitude 6,900 ft., July 15 (H. F. Wickham). Walnut, July 20 , paratype.

California : Twin Lakes, Mono County, 1931 (R. E. Blackwelder).

Colorado: Colorado Springs, June 15-30, 1896, altitude 6,000-7,000 ft. (H. F. Wickham). Ute Pass (A. B. Champlain). No locality (Hubbard and Schwarz).

Montana : Kalispell, June 13-20 (H. F. Wickham).

New Mexico: Las Vegas Hot Springs, August 8 (Barber and Schwarz).

South Dakota: Elmore, July 7, 1902 (J. L. Webb). Lead, September 1, 1899.

Wroming: Yellowstone National Park, September (H. F. Wickham). Laramie, type.

British Columbia : Kokanee Mountains, August 10, 1903, collected on snow, altitude 9,000 ft. (R. P. Currie).

Host.-This species has been reared from Pinus edulis collected in Colorado by A. B. Champlain.

Casey described this species from three specimens, the type from Laramie, Wyo., and paratypes from Williams and Walnut, Ariz.

Stephanopachys conicola, new species

Uniformly dark reddish brown, the antennae, palpi, and legs slightly paler.

Head with front and clypeus rather coarsely granulose, sparsely clothed with rather short, recumbent, yellowish hairs, the clypeus glabrous, and finely, densely granulose along anterior margin; mentum feebly, broadly lobed in front.

Pronotum strongly, uniformly convex, not gibbose in front of scutellum, widest near middle; sides broadly rounded, finely, irregularly serrulate along margins; surface sparsely clothed with short, inconspicuous, erect hairs on disk, the hairs long toward sides and anterior margin, densely, coarsely granulose, the granules on basal half strongly elevated and distinctly separated from one another, apical half with numerous broad, strongly elevated teeth, which are longer, narrowly rounded at apices, and sometimes contiguous at bases along anterior margin. 
Elytra at base slightly wider than pronotum near middle; surface coarsely, densely, irregularly punctate, the punctures on disk not so wide as intervals, sparsely clothed with erect, yellowish hairs, uniform in length, and as long as width of punctures on basal half of disk, but much longer toward sides and on apical declivity, intervals on disk smooth, without distinct granules; apical declivity coarsely, irregularly punctate.

Abdomen beneath sparsely, coarsely granulose, sparsely clothed with short, recumbent, yellowish hairs.

Length $2.5-3.2 \mathrm{~mm}$.; width $1-1.4 \mathrm{~mm}$.

Type locality.-Williams, Ariz.

Described from seven specimens (one female type). The type was collected July 25, on white fir (Abies concolor Lindley and Gordon), by Barber and Schwarz, and six paratypes were collected in the San Gabriel Mountains in southern California from cones of single-leaf pinon (Pinus monophylla Torrey and Fremont) by J. E. Patterson. Type and paratypes.-In the United States National Museum, No. 58312 .

Stephajopachys cribratus (LeConte)

Dinoderus cribratus LeConte, 1866, Smithsn. Inst. Misc. Collect. 167: 102; Horn, 157s, Amer. Phil. Soc. Proc. 17: 549; Casey, 1S9S, N. Y. Ent. Soc. Jour. 6: 75. Stephanopachys cribratus Lesne, 189S, Soc. Ent. de France Ann. (1897) 66:334, 336; Leonard, 1928, N. Y. (Cornell) Agr. Expt. Sta. Mem. 101: 415; Knull, 1934, Ent. News 45: 209; Lesne, 1938, in Junk (pub.), Coleopt. Cat., pt. 161, p. 20 ; Brimles, 1938, Insects of North Carolina, p. 198.

Uniformly dark reddish brown to brownish black, the antennae, palpi, and legs slightly paler.

Head with front and clypeus coarsely, sparsely granulose, the granules round and flattened, sparsely clothed with short, inconspicuous hairs, the clypeus glabrous and smooth along anterior margin; labrum irregularly, indistinctly punctate; mentum subtruncate in front.

Pronotum strongly, uniformly convex, not gibbose in front of scutellum, widest near middle; sides broadly rounded, irregularly serrulate along margins; surface sparsely clothed with short, inconspicuous hairs on disk, the hairs long and erect toward sides and anterior margins, densely, coarsely granulose on basal half, the granules flattened, contiguous, and in front of scutellum rounded, apical half with numerous broad, short, strongly elevated teeth, which are broadly rounded at apices and contiguous at bases along anterior margin.

Elytra at base subequal in width to pronotum near middle; surface coarsely, densely, irregularly punctate, the punctures on disk not so wide as intervals, glabrous on disk, sparsely clothed with moderately long, erect hairs at sides and on apical declivity, intervals smooth, not granulose; apical declivity coarsely, irregularly punctate.

Abdomen beneath sparsely, coarsely, shallowly punctate, sparsely clothed with short, recumbent, yellowish hairs.

Length $3.5-5 \mathrm{~mm}$., width $1.2 \check{5}-2 \mathrm{~mm}$.

Type locality.-Middle States, no definite locality; type in the LeConte Collection in the Museum of Comparative Zoology at Cambridge, Mass.

Distribution.-Material has been examined from various localities in the following States: Arizona, District of Columbia, Georgia, Idaho, $842409-50-4$ 
Indiana, Michigan, Montana, Nebraska, New Jersey, New York, North Carolina, Pennsylvania, South Carolina, South Dakota, Texas, Virginia, Washington, and Wisconsin.

Hosts.-This species has been reared from Pinus ponderosa in Idaho and Pinus strobus in Virginia. Knull (1934) collected adults in the outer bark of a living pitch pine tree, and L. A. Hetrick collected adults at Chatham, Va., infesting the bark of Pinus taeda trees that suffered severe fire injury during the preceding year.

\section{Stephanopachys densus (LeConte)}

Dinoderus densus LeConte, 1866, Smithsn. Inst. Misc. Collect. 167: 102 ; Horn, 1878, Amer. Phil. Soc. Proc. 17: 549-550 ; Casey, 1898, N. Y. Ent. Soc. Jour. $6: 75$.

Stephanopachys densus Lesne, 1898, Soc. Ent. de France Ann. (1897) $66: 324$, 326 : Leonald, 1928, N. Y. (Cornell) Agr. Expt. Sta. Mem. 101: 415; Brimley, 1938, Insects of North Carolina, p. 198.

The following is a copy of LeConte's original description:

Elongatus, cylindricus, niger subopacus, setis fulvis erectis vestitus, thorace latitudine haud breviors, lateribus antice cum apice rotundatis et fortiter dentatis, postice subparallelis subserratis, angulis posticis rotundatis, disco convexo dense granulato, granulis anticis acutis; elytris confertim fortiter punctatis, subgranulatis, postice aequaliter convexis. Long. .12.

Two specimens; New York. Differs from $D$. substriatus by the thorax being more densely granulate and by the elytra not being substriate, and from $D$. porcatus by the elytra not being so rough, and from both by the sides of the thorax from the middle being only feebly serrate.

The types of this species in the LeConte Collection have not been examined. The characters used in the key for separating densus and hispidulus are based entirely on the specimens identified as those two species in the Casey Collection. The specimens of densus and hispidulus as identified by Casey are both valid species, but there may be some doubt about Casey's identification of densus. If not correct, his hispidulus might be a synonym of densus LeConte and his specimen identified as densus would require a new name. The Casey specimens identified as densus LeConte are from South Carolina.

\section{Stephanopachys hispidulus (Casey)}

Dinoderus hispidulus Casey, 1898, N. Y. Ent. Soc. Jour. 6: 75.

Stephanopachys hispidulus Leonard, 1928, N. Y. (Cornell), Agr. Expt. Sta. Mem.

101 : 415 ; Lesne, 1938, in Junk (pub.), Coleopt. Cat., pt. 161, p. 20.

Dinoderus parvulus Casey, 1898, N. Y. Ent. Soc. Jour. 6: 75. (New synonymy).

Stephanopachys parvulus Lesne, 1938, in Junk (pub), Coleopt. Cat., pt. 161, p. 21.

Uniformly dark reddish brown to brownish black, the palpi, antennal clubs, and tarsi brownish yellow.

Head with front and clypeus coarsely, densely granulose or punctate, sparsely clothed with long, inconspicuous, erect hairs; labrum coarsely, uniformly punctate; mentum subtruncate in front.

Pronotum strongly convex, slightly gibbose in front of scutellum, widest near middle; sides broadly rounded, feebly, irregularly serrulate along margins: surface sparsely clothed with rather long, recumbent hairs on disk, the hairs long and erect toward sides and anterior margin, coarsely, densely granulose on basal half, the granules flattened, distinctly separated, and slightly elongate in front of scutellum, apical half with numerous broad, short, strongly elevated teeth, which are longer, acutely rounded at apices, and separated at bases from one another along anterior margin. 
Elytra at base subequal in midth to pronotum near middle: surface coarsely. densely, irregularly punctate. the punctures on disk not so wide as intervals, rather densely clothed with long, recumbent and erect, vellowish hairs on basal half of disk, the hairs more erect along sides and on apical declivity, intervals slightly scabrous: apical declivity rather densely, coarsely granulose.

Abdomen beneath rather densely, coarsely punctate, rather densely clothed with moderately long, recumbent, rellowish hairs.

Length $2.5-4.5 \mathrm{~mm}$.. width $1-1.5 \mathrm{~mm}$.

Type locality.-Of hispidulus, New Jersey, no definite locality. Of parvulus. Pennsylrania, no definite locality. Types in the Casey Collection in the United States National Museum.

Distribution.-From material examined:

District of Coldmbia: Washington, June 22 (Hubbard and Schwarz).

MARYLAXD: Odenton, May 25 (Hubbard and schwarz).

North Carolina: Durham. New Bern, April 24. 1917 (R. W. Leiby).

New Jersey: Clementon, July 22 (H. A. Kaeber).

New York: West Point, June 15, 1913 (W. Robinson).

Pexisyltaxia: Philadelphia (G. M. Greene).

Rhode Islaxd: Watch Hill, June 30, 1909 (W. Robinson).

Virgixia : Falls Church (A. B. Champlain).

Hosts.-This species has been reared from Pinus taeda and Pinus virginiana.

Casey described hispidulus from a unique specimen from Ner Jerser. and parvulus from a single specimen from Pennsrlvania. Dinoderus parvulus seems to be merely a small specimen of Dinoderus hispidulus.

\section{Subfamily BOSTRICHINAE}

\section{Tribe DiNapatini}

Dinapatinae Lesne, 1910, Soc. Ent. de France Ann. (1909) is:4i1-473.

Dinapatini Lesne, 1921, Assoc. Franc, pour l'A ranc. des. Sci., Cong. de Strasbourg (1920), p. $28 s$.

Dinapatina Lesne, 1938, in Junk (pub.), Coleopt. Cat., pt. 161, pp. 74-75.

Lesne (1910) erected the subfamily Dinapatinae for Dinapate Horn. This is the only known genus in the tribe.

\section{Genus DINAPATE Horn}

Dinapate Horn, 18s6, Amer. Ent. Soc. Trans. 13: 1-4; Casey, 1898, N. I. Ent. Soc. Jour. 6: 66-67; Lesne, 1910, Soc. Ent. de France Ann. (1909) Ts: 473477; 1939, in Junk (pub.), Coleopt. Cat., pt. 161, pp. 74-75.

Head short, deeply inserted in pronotum, not visible from abore; clypeus strongly transrerse, truncate in front, feebly, obtusely dentate on each side of labrum; labrum strongly transverse, subtruncate and densely ciliate with long, brownish-yellow hairs in front; maxillary palpi slightly longer than labial, densely pubescent, apical segment of each elongate-oral, subtruncate at apex: mandibles attenuate toward apices, which are acute; eres large, oval, slightly projecting: margins of buccal carities not dentate below eyes. Antenna very short, 10 segmented; first segment robust, rather short, nearly three times as long as second; second slightly elongate, narrower than first: third to serenth segments short, transverse: last three segments forming a broad, loose club, clothed with a few long, erect hairs, the eighth and 
ninth segments strongly transverse, caliciform (cup-shaped), smooth, with a few coarse punctures on median parts, porous at sides, the tenth segment irregular in shape, narrower than ninth. Pronotum strongly convex, declivous anteriorly, not transversely depressed behind anterior margin, which is not dentate, subtruncate at apex, truncate at base; sides not margined. Scutellum small, quadrate, strongly elevated. Elytra strongly convex, with distinct tubercles at anterior margin of apical declivity; humeri not carinate. Legs rather long, subequal in length; tibiae compressed, strongly expanded toward apices, armed on exterior margins with a few large, triangular teeth, each tibia with a long, slightly arcuate spine on inner margin and two or three triangular teeth on outer margin at apex; posterior tarsi as long as tibiae, apical segment of each as long as second segment, third and fourth segments very short; tarsal claws long, with a long onychium at base. Anterior coxae continuous. Middle coxae narrowly separated. Intercoxal process of abdomen narrow. Body very large, cylindrical.

$$
\text { Genotype.-Dinapate wrightii Horn. (Monobasic.) }
$$

\section{Dinapate wrightil Horn}

Dinapate wrightii Horn, 1886, Amer. Ent. Soc. Trans. 13: '2-4, pl. 1, figs. 1-12; Casey, 1898, N. Y. Ent. Soc. Jour. 6: 67; Hubbard, 1899, Wash. Ent. Soc. Proc. 4: 228, 230; 1899, Ent. News 10: 83-89; Fényes, 1901, Rov. Lapok. 8: 4-7; Lesne, 1910, Soc. Ent. de France Ann. (1909) 78: 473-477, figs. 572, 573, pl. 4, figs. 1-4; Martin, 1917, Brooklyn Ent. Soc. Bul. 12: 107-110, pl. 1; Garnett, 1918, Ent. News 29: 41-44, pl. 2; Comstock. 1922, South. Calif. Acad. Sci. Bul. 21: 5-17, pls. A-B; Garnett, 1922, Soc. Ent. de France Bul. pp. 119-121, pl. 1, figs. 1-4: Campbell, 1923, Pomona Col. Jour. Ent. and Zool. 15: 61-65. pl. 1; Wymore, 1928, Pan-Pacific Ent. 4: 143; Lesne, 1938, in Junk (pub.), Coleopt. Cat., pt. 161, pp. 74-75; Anderson, 1939, Wash. Acad. Sci. Jour. 29 (9) : 390 (larvae) ; Iichelbacher and Ross, 1939, Calif. Dept. Agr. Bul. 28: 166-169, figs. 1-3; Davis, 1940, Wash. Ent. Soc. Proc. 42: 129-134 (biological notes).

Male.-Black. sometimes with a reddish tinge, strongly shining. the antenna (except club which is brownish yellow), palpi, legs, and underside of body, dark reddish brown.

Head slightly convex, transversely, shallowly concave behind eves, with a few erect hairs near eyes and on clypeus, finely, indistinctly punctate on front and clypeus, finely, densely granulose on occiput; clypeal suture very fine, sometimes slightly depressed at middle, obsolete at sides.

Pronotum wider than long, widest in front of middle; sides broadly rounded, more obliquely posteriorly; apical and posterior angles broadly rounded; base narrowly, transversely constricted; surface sparsely clothed with short, recumbent and erect, inconspicuous hairs, densely ciliate along anterior margin with long, brownish-yellow hairs, densely, finely granulose near posterior angles, very densely squamose on rest of surface, the scales variable in size, and with numerous short, broad, rasplike teeth in front of middle.

Elytra at base subequal in width to pronotum in front of middle; sides nearly parallel; subtruncate or sinuate at apices, with sutural angles rectangular and triangularly separated; surface glabrous, coarsely, densely, irregularly punctate on dorsal part, the punctures finer toward sides and obsolete on apical declivity; sutural margins 
slightly expanded and elevated at middle of apical declivity; each elytron with two tubercles at anterior margin of apical declivity, the sutural one long and acute. the lateral one costiform and obtuse at apex, and with four or fire obtusely rounded. longitudinal costae.

Body beneath densely clothed with long. recumbent and semierect, brownish-yellow hairs; abdomen finely, densely granulose; last visible sternite broadly rounded at apex.

Female.-Differs from the male in having the front of head and clypeus distinctly, finely granulose, the sutural tubercle on anterior margin of the apical declivity of each elytron short and obtusely rounded at the apex, and the surface on the declivity finely, densely punctate and granulose.

Length 33-气̃ $1 \mathrm{~mm}$. . width 8-18 $\mathrm{mm}$.

Type locality.-Palm Springs, Calif. Type in the Horn Collection in the Academy of Natural Sciences of Philadelphia.

Distribution.-According to present knowledge of the distribution of this species it occurs in the canyons on the east side of the Colorado Desert, Calif. (formerly the upper end of the Gulf of California), and at least as far south as (atarina, Lower California, about 300 miles south of Palm Springs, Calif. It has been recorded from Palm, Murray, Andreas. Taquitz. Chino, and Thousand Palm Canyons, and Seven Palms, Calif.. and Catavina. Lower California.

Hosts.-It has been found only in the Washington or fan palm (Washingtonia filifera Wendl.). It has been reported as attacking date palms in the Coachella Vallev, Calif., but this report should be verified.

Horn (1886) described wrightii from specimens collected by W. G. Wright in the Mojave Desert. Calif., and for which he erected the genus Dinapate. This is the only known species of Dinapate, and also the largest known bostrichid. Hubbard (1899) considered this beetle rare and stated that the species would soon become extinct. However, from 1917 to 1930 the beetles assumed the proportions of a minor pest in Palm Springs. A number of large palms had been transplanted into the village, and Wymore (1928) writes that 90 percent of these palms were severely injured by the beetles burrowing into the succulent growing tips of the palms and also in the trunks of the living palms, causing some to die. Hubbard (1899), while at San Diego, Calif., ascertained that the type locality of Dinapate wrightii is Palm Springs, Calif., and not the Mojare Desert, as stated by Horn. Dr. Murray, the landlord of a little hotel at Palm Springs, told him that Mr. Wright came almost every September to that place and alwars went up into the canyon. Hubbard stated that he could easily trace the operations of Mr. Wright among the fallen palm trunks. Wright had even cut down a number of the largest and tallest trees, no doubt in the hope of attracting the beetles to the freshly cut timber.

\section{Tribe BostRICHINI}

Bostrichini LeConte. 1861, Smithsn. Inst. Misc. Collect. 3 (1) : 207-20s; Kiesenwetter, 1877, in Erichson. Naturgesch. Insect. Deut., Coleopt.. v. 5, pt. 1, pp. 7. 25-41, fig. ; LeConte and Horn, 18s3. Smithsn. Inst. Misc. Collect. $507: 227.225$. Bostrichinae Anderson, 1939, Wash. Acad. Sci. Jour. 29: 390-391 (larvae). Bostrychini Lesne, 1901. Abeille 30: 81-110; Csiki, 1903, Ror. Lapok. 10 : 17-20; Lesne, 1921, Assoc. Frans. pour l'Avanc. des. Sci., Cong. de Strasbourg (1920), 
p. 288 ; Everts, 1922, Coleopt. Neerlandica, v. 3, p. 364; Lesne, 1924, Bostrychides de l'Afrique Tropicale Française, pp. 111-208.

Bostrychina Jakobson, 1913, Käfer Russland, pt. 10, pp. 801, 803-805.

This is one of the largest tribes of Bostrichidae, containing many genera which are found in all parts of the world. Species belonging to nine of these genera are either established in the United States, or have been intercepted in commerce.

\section{KEY TO THE GENERA OF BOSTRICHINI}

1. Posterior coxal cavities completely margined on first visible abdominal sternite

Posterior coxal cavities not completely margined on first visible abdominal sternite.

2. Mandibles more or less attenuate toward apices; antennal club not flabellate nor with segments strongly transverse

Mandibles very short, broad and truncate at apices; antennal club flabellate or with segments strongly transverse__ Sinoxylon Duftschmid, p. 57.

3. Margins of buccal cavities strongly dentate below eyes

4. Segments of antennal club with longitudin eyes _..._..............face...

Segments of antennal club without longitudinal depressions, but with round depressions on each surface.

5. Anterior angles of clypeus broadly rounded (except in truncatus) Lichenophanes Lesne, p. 75.

Anterior angles of clypeus obtuse, acute, or rectangular.

6. Pronotum transversely depressed behind anterior margin

Heterobostrychus Lesne, p. 83.

Pronotum not transversely depressed behind anterior margin

7. Front of head transversely depressed or flattened behind eyes

Front of head regularly convex behind eyes...... Micrapate Casey, p. 87.

8. Front of head transversely, perpendicularly elevated behind clypeus

Apatides Casey, p. 95.

Front of head not transversely, perpendicularly elevated behind clypeus, sometimes with a short, more or less distinct, elevation at middle behind clypeus........

\section{Genus BOSTRICHUS Geoffroy}

Bostrichus Geoffroy, 1762, Historie Abrégée des Insects, v. 1, pp. 301-303, pl. 5, fig. 1 ; Müller, 1764, Fauna Insectorum Fridrichsdalina, p. xii ; Fabricius, 1775, Systema Entomologie, pp. 59-60 (part) ; 1777, Genera Insectorum, p. 14; Stephens, 1830, Illus. Brit. Ent., Mandibulata, v. 3, pp. 349-350 ; Wollaston, 1854, Ins. Maderensia, p. 288; Thomson, 1859, Skandinaviens Coleopt., v. 1, p. 92; LeConte, 1861, Smithsn. Inst. Misc. Collect. 3 (1) : 208; Thomson, 1863, Skandinaviens Coleopt., v. 5, pp. 199-200 ; Kiesenwetter, 1877, in Erichson, Naturgesch. Insect Deut., Coleopt., v. 5, pt. 1, pp. 34-37; Seidlitz, 1889, Fauna Transylvanica, Kaefer, pp. 116, 530; 1889, Fauna Baltica, Kaefer, pp. 116, 495 ; Lesne, 1899, Soc. Ent. de France Ann. (1898) $67: 442,447-455$.

Bostrychus Zoufal, 1894, Wien. Ent. Ztg. 13: 35, 40-41; Schilsky, in Küster and Kraatz, Käfer Europas 36: pp. TT; Lesne, 1901, Abeille 30:86, 88-90, pl. 1, fig. 30 ; Csiki, 1903, Rov. Lapok. 10: 18; Lesne, 1905, Abeille 30: 249 ; Reitter, 1911, Fauna Germanica, v. 3, pp. 301, 303; Jakobson, 1913, Käfer Russland, pt. 10, pp. 803, 805; Everts, 1922, Coleopt. Neerlandica, v. 3, p. 365 ; Lesne, 1938, in Junk (pub.), Coleopt, Cat., pt. 161, pp. 31-33.

Apate Redtenbacher, 1845̃, Gattungen Deut. Kaefer Fauna, p. 94; 1847-1849, Fauna Austriaca, Käfer, pp. 35, 354; Jacquelin-Duval, 1859-1863, Genera Coléopt.. Europe, v. 3, pp. 230, 233, pl. 56, fig. 279 ; Everts, 1901, Coleopt. Neerlandica, v. 2, pp. 210, 211-212.

Head slightly convex on occiput, transversely flattened behind eyes, deeply inserted in prothorax, not visible from above; clypeus strongly 
transverse, raguely, broadly, arcuately emarginate or subtruncate in front, anterior angles obtuse ; clypeal suture usually distinct at middle, more obsolete toward sides; labrum small, very short, subtruncate and densely ciliate with long, yellow hairs in front; margins of buccal ravities not dentate below eyes; mandibles more or less attenuate toward apices; eyes oval, subglobose, strongly projecting. Antenna short, 10-segmented; first and second segments robust, oblong, second shorter than first; third to seventh segments narrower than second, subequal in length to one another; last three segments forming a broad, loose, compressed club, the segments subequal in length to one another, each with small, round, sensory depressions on each surface, eighth and ninth subtriangular, tenth oblong. Pronotum strongly convex, dentate anteriorly, truncate at base and apex ; posterior angles rectangular ; sides not margined. Scutellum small, quadrate. Elytra strongly convex, arcuately declivous posteriorly, without tubercles on apical declivity. Legs short, subequal in length; tibiae slender, slightly expanded toward apices, not distinctly dentate on exterior margins, anterior pair with a small arcuate spine at apices; posterior tarsi as long as, or longer than tibiae, apical segment of each shorter than preceding four segments united. Anterior coxae contiguous. Middle coxae narrowly separated. Posterior coxal cavities not completely margined on first visible abdominal sternite. Intercoxal process of abdomen narrowly triangular. Body elongate, slightly depressed.

Genotype.-Dermestes capucinus Linnaeus. (Monobasic.)

Geoffroy (1762) erected the genus Bostrichus for a species without giving it a specific name, but figured the adult. Schaeffer (1766) also figured the adult without giving it a name. Limnaeus (1767) under Dermestes capucinus referred to the figures given by Geoffroy and Schaeffer as capucinus Linnaeus. Fourcroy (1785) in giving names to the species in Geoffroy (1762) states that the figure 1 on page 5 was Dermestes capucinus Linnaeus. Thomson (1859) stated that Dermestes capucinus Linnaeus is the type of Bostrichus Geoffroy.

\section{Bostrichus CAPUcinus (Linnaeus)}

Dermestes capucinus Linnaeus, 1758, Systema Naturae, ed. 10, p. 355; 1761, Fauna Suecica, ed. 2, p. $142 ; 1767$, Systema Naturae, ed. 12, v. 1, pt. 2, p. 562; Sulzer, 1776, Geschichte der Insecten, p. 21, pl. 2, fig. 5.

Bostrichus sp., Geoffroy, 1762, Histoire Abégée des Insecten, v. 1, pl. 5, fig. 1; Schaeffer, 1766, Elementa Entomologica, pl. 28.

Bostrichus capucinus Fabricius, 1775, Systema Entomologie, p. 59 ; 1781, Species Insectorum, v. 1, p. 67; Fourcroy, 1785, Entomologia Parisiensis, p. 133; Fabricius, 1787, Mantissa Insectorum, v. 1, p. 36: Olivier, 1790, Encyc. Méthodique, Insectes, v. 5, pp. 107, 109; Rossi, 1790, Fauna Etrusca, r. 1, p. 36. pl. 5, fig. 3; Olivier, 1795, Entomologie, v. 4, Gen. 77, pp. 8-9, pl. 1. fig. 1; Latreille, 1807 , Hist. Nat. Crust. et Ins., r. 3, pp. 6-7; Stephens, 1830, Illus. Brit. Ent., Mandibulata, v. 3, p. 350 ; Westwood, 1839, Introduction to the Modern Classification of Insects, v. 1, pp. 276-277, fig. 31, Nos. 4-10: Spry and Shuckard, 1840, Brit. Coleopt., p. 44, pl. 53, fic. 3; Kiesenwetter, 157 7 , in Erichson, Naturgesch. Insect. Deut., Coleopt., v. 5, pt. 1, pp. 35-36; Fowler, 1s90, Coleopt. Brit. Isl., v. 4, p. 201, pl. 119, fig. 2.

Bostrychus capucinus Zoufal, 1894, Wien. Ent. Ztæ. 13: 40; Lesne, 1S99. Soc. Ent. de France Ann. (1898) $67: 448-455$, figs. 49-53; 1901, Abeille 30 ; $\$ \$-90$. pl. 1, fig. 30 ; Reitter, 1911, Fauna Germanica, v. 3, p. 303, pl. 120, fig. 11 ; Lesue, 1938, in Junk (pub.), Coleopt. Cat., pt. 161, pp. 31-33.

Aprte capucinus Fabricius, 1792, Ent. Srstem., v. 1. pt. 2, p. 362: Panzer, 1797. Fauna Ins. Germ., fase. 42, fig. 18: Parkull, 1S00, Fauna Suecica, v. 3. pp. 141142 ; Fabricius, 1801, Systema Eleutheratorum, v. 2, p. 381; Curtis, 1s29, Brit. 
Ent., v. 6, No. 271, pl. 271; Perris, 1850, Soc. Ent. de France Ann. (ser. 2) 8: 555-559, pl. 16, figs. $1-8$.

Ligniperda capucinus Herbst, 1793, Natursystem Insekten, Käfer, v. 5, pp. 34-36, pl. 46 , fig. 7 .

The foregoing bibliography is not complete, as only the more important articles are cited.

Male.-Elongate, slightly depressed, black, except elytra and four posterior abdominal sternites, which are red; antennae, palpi, labrum, and tarsi reddish brown.

Head much narrower than pronotum, uneven, sometimes with a more or less distinct longitudinal groove on vertex; coarsely, confluently, rugosely punctate, sparsely clothed with long, erect, inconspicuous hairs.

Pronotum slightly wider than long, widest near middle, strongly deflexed on apical half; sides broadly rounded, more strongly converging anteriorly than posteriorly; surface uneven, coarsely, densely, irregularly punctate, coarsely, confluently granulose between punctures, with numerous, irregularly placed, broad, rasplike teeth at sides on anterior half, and a transversely arcuate ridge, which is interrupted at middle, near anterior margin, rather densely clothed with long, erect, brownish hairs at sides and along anterior margin.

Elytra at base subequal in width to pronotum at middle, with a narrow, smooth costa extending along lateral margins from humeri to apical declivity; sides parallel, conjointly broadly rounded at apices; surface glabrous, shining, densely, deeply, coarsely punctate, sometimes more or less rugose on apical declivity.

Body beneath densely, finely punctate, sparsely clothed with long, semierect hairs on sternum and apex of last abdominal sternite, with very short, recumbent, inconspicuous hairs on abdomen. Posterior tarsi armed on underside with long, silky, brown hairs.

Female.-Differs from the male in not having the long, silky brown hairs on the underside of the posterior tarsi.

Length 7.5-16 mm., width $2.5-5.5 \mathrm{~mm}$.

Type locality.-Europe; location of type is unknown to the writer.

Distribution.-This species is found in all of Europe (except Norway, Sweden, Scotland, Ireland, and northern Russia), the Mediterranean Islands, Morocco, Algeria, northern Tunis, Asia Minor, Syria, and Caucasus. Adults of this species were intercepted at Newark, N. J., and New York in licorice roots from Turkey. Adults of capucinus were reared from the oak strips used for binding large quantities of cork stored along the railroad tracks near Nicholson, Miss., during 1943-44. This material was shipped from northern Africa. One specimen of the black variety, Bostrichus capucinus var. luctuosus Olivier, was also reared from the same material. So far as known, the species has not become established in the United States.

Hosts.-Lesne (1901) states that in the temperate parts of Europe this species prefers the stumps and large roots of oak, but also lives in a number of other plants. It has been recorded in the literature as living in chestnut, locust, mulberry, myrtle, grape, strawberry tree, English oak (Quercus robur), evergreen oak (Quercus ilex), Quercus toza, Calyctome spinosa, and the jujube tree (Zizyphus lotus). It has also been recorded in pine, but this may be an error. 


\section{Genus SINOXYLON Duftschmid}

Sinoxylon Duftschmid, 1825, Fauna Austriae, v. 3, pp. 85-86; Redtenbacher, 1845, Gattungen Deut. Kaefer Fauna, p. 94; 1847-1849, Fauna Austriaca, Käfer, pp. 35, 354 ; Lacordaire, 1857, Genera des Coléopt., v. 4, pp. 534, 538; JacquelinDuval, 1859-1863, Genera Coléopt. Europe, v. 3, pp. 229, 233, pl. 56, fig. 277; LeConte, 1861, Smithsn. Inst. Misc. Collect. 3 (1): 207 ; Redtenbacher, 187t, Fauna Austriaca, Käfer, ed. 3, v. 1, p. XCII, vol. 2, p. 65; Kiesenwetter, 1877, in Erichson, Naturgesch. Insect. Deut. Coléopt., v. 5, pt. 1, pp. 31-34; Seidlitz, 1889, Fauna Transylvanica, Kaefer, p. 116, 529; 1889, Fauna Baltica, Kaefer, pp. 116, 495; Zoufal, 1894, Wien. Ent. Ztg. 13: 34, 37-38: Schilsky, 1899, in Küster and Kraatz, Käfer Europas, 36 : pp. UU, YY-ZZ; Lesne, 1901, Abeille 30: 110-118; Csiki, 1903, Rov. Lapok. 10: 17, 20; Lesne, 1906, Soc. Ent. de France Ann. 75: 447, 462-545; Reitter, 1911, Fauna Germanica, v. 3. pp. 302, 305 ; Jakobson, 1913, Käfer Russland, pt. 10, pp. 805, 807 ; Lesne, 1924, Bostrychides de l'Afrique Tropicale Française, pp. 115, 176-199; 1938, in Junk (pub.), Coléopt. Cat., pt. 161, pp. 48-54; 1939, Soc. Zool. de France, Bul. 73: 404-415, figs.

Apatodes Blackburn, 18s9, Linn. Soc. N. S. Wales, Proc. (1898), ser. 2, 3: 1429. Trypocladus Guérin-Ménéville, 1845, Soc. Ent. de France Ann. (ser. 2) 3: Bul., p. XVII.

Head strongly convex, not transversely depressed behind eyes, deeply inserted in prothorax, not visible from above; clypeus strongly transverse, flat, truncate or sinuate in front, with a small tooth on each side at base of labrum : labrum transverse, broadly rounded, and densely ciliate with long, yellow hairs in front; mandibles very short, broad and truncate at apices; eyes small, oval, subglobose, strongly projecting. Antenna short, 10-segmented; first and second segments robust, elongate, second shorter than first; third to seventh segments very short, compact, transverse, narrower than second segment, subequal in length to one another; last three segments forming a loose, compressed, strongly transverse or flabellate club, with or without distinct sensory depressions on each surface. Pronotum strongly convex, truncate or arcuately emarginate in front, arcuately emarginate at base, dentate anteriorly, not transversely depressed behind anterior margin; sides not margined. Scutellum small, quadrate or triangular. Elytra strongly convex, tuberculate on apical declivity. Legs short, subequal in length; tibiae expanded toward apices, each with a large, arcuate spine at apex, the anterior and middle pairs dentate on exterior margins; posterior tarsi as long as, or longer than tibiae, apical segment of each shorter than preceding four segments united. Anterior coxae contiguous. Middle coxae narrowly separated. Posterior coxal cavities completely margined on first visible abdominal sternite. Intercoxal process of abdomen tabular or triangular. Body short or elongate, cylindrical.

Genotype.-Of Sinoxylon, Sinodendron muricatum Fabricius. (Monobasic.) Of Apatodes, Apatodes macleayi Blackburn. (Monobasic.) Of Trypocladus, Bostrichus sexdentatum Olivier. (Present designation.)

This genus contains at least 50 described species, which are distributed throughout Southern and Central Europe, Asia, Africa, Australia, Japan, and Malasia. Some of the species have been carried in commerce to other parts of the world. Five of the species have been intercepted at various times in the United States, but so far as known have not become established. 


\section{KEY TO THE SPECIES OF SINOXYLON}

1: Submarginal carina along lateral margin of elytron sharply elevated posteriorly, curving inward to sutural margin and forming the anterior margin of apical concavity; antennal club flabellate_ anale Lesne, p. 58.

Submarginal carina along lateral margin of elytron not curving inward, but following outline of lateral margin; apical declivity not margined anteriorly; antennal club flabellate, or with segments strongly transverse

2. Antennal club flabellate, each segment four times as wide as long, first segment not subtriangular........... conigerum Gerstacker, p. 60.

Antennal club not flabellate, each segment twice as wide as long, first segment subtriangular

3. Elytra with costiform tubercles at anterior margin of apical declivity

Elytra without costiform tubercles at anterior margin of apical declivity _. . .

4. Each elytron with three costiform tubercles at anterior margin of apical declivity, and a triangular, compressed tubercle at middle of declivity along sutural margin _............... ruficorne Fåhraeus, p. 62.

Each elytron with one costiform tubercle at anterior margin of apical declivity and with two conical tubercles placed transversely at middle of declivity, the outer tubercle short and obtuse at apex, the inner one long, acute at apex, and placed some distance from sutural margin _........ sexdentatum (Olivier), p. 63.

\section{Sinoxylon anale Lesne}

Sinoxylon anale Lesne, 1897, Soc. Ent. de Belg. Ann. 41:21-22 ; Stebbing, 1902, India Dept., Notes on Insects Affecting Forests, No. 1, pp. 16-18, pl. 1, fig. 2; 1903, ibid., No. 2, pp. 166-167; Lesne, 1905, Abeille $30: 250$; 1906, Soc. Ent. de France Ann. 75: 465, 478-482, fig. 517; Lefroy, 1909, Indian Insect Life, p. 317, fig. 196; Stebbing, 1914, Indian Forest Insects, pp. 4, 14, 18, 19, 50, 62, 95, 96, 104, 112, 114, 115, 167-174, 183, 188, figs. 113-117 ; Froggatt, 1927, Austral. Forest Insects and Timber Borers, pp. 18-20, 103, pl. 12, figs. 1-3; Gardner, 1933, Indian Forest Rec. Ent. Ser. 18 (9): 18 (larvae) ; Miller, 1934, Straits Settlements and Fed. Malay States, Dept. Agr., Sci. Ser. No. 14, pp. 1, 2, 4, 5, 9, 12-15, pl. 1, figs. 2-5; Cann, 1935, Indian Forester 51 (3) : 165; Beeson and Bhatia, 1937, Indian Forest Rec. New Ser., Ent., 2: 226, 229, 285-289, 309-320, fig. 14, pl. 2, fig. A ; Lesne, 1938, in Junk (pub.), Coleopt. Cat., pt. 161, p. 48.

Sinoxylon geminatum Schilsky, 1899, in Küster and Kraatz, Käfer Europas 36 : No. 80 ; Lesne, 1902, Abeille $30: 112,117 ; 1905,30: 249$.

Apatodes macleayi Blackburn, 1889, Linn. Soc. N. S. Wales Proc. (1888), ser. 2, 3: 1429.

Body short. Black or dark reddish brown, basal half of elytra, posterior angles of pronotum usually more reddish, the antennae, palpi, legs, and abdomen in part brownish yellow.

Head with four small tubercles along anterior margin, densely, coarsely granulose, and sparsely clothed with short, recumbent, whitish hairs on front, with long, fine, longitudinal, parallel costae on occiput; clypeus finely sparsely granulose, with a transverse, sinuate carina near anterior margin, the carina angulate at middle and extending on each side to tooth at base of labrum; clypeal suture distinct; labrum very finely, densely punctate. Antennal club strongly flabellate, sparsely clothed with fine, recumbent, inconspicuous hairs; first segment of club narrowest, sides nearly parallel; second wider than length of first seven segments united; third finely grooved on anterior surface.

Pronotum slightly wider than long. widest near middle; sides slightly rounded posteriorly. more strongly converging anteriorly, with a small, unciform tooth at apical angles; posterior angles broadly 
rounded; surface sparsely clothed with short, recumbent, inconspicuous hairs, finely, sparsely granulose at sides on basal half, imbricatepunctate at middle on basal half, densely granulose and irregularly dentate on apical half, the teeth broad, semierect, variable in size, and rasplike. Scutellum triangular.

Elytra at base subequal in width to pronotum at middle; sides slightly expanded posteriorly, conjointly broadly rounded at apices; submarginal carina sharply elerated along apical declivity, curving inward along top of apical declivity to sutural margin; surface sparsely clothed with short. recumbent, yellowish hairs, which are denser on apical declivity and along lateral margins, coarsely, densely, irregularly punctate, usually finely punctate on posterior half of apical declivity; apical declivity obliquely deflexed. more or less distinctly margined anteriorly, with two smooth, erect, conical tubercles along sutural margins at middle of declivity. the tubercles narrowly separated at bases, acute and somewhat curved at apices; sutural margins broad, strongly elevated, and coarsely dentate along inner margins between tubercles and apices.

Body beneath densely, finely punctate, densely clothed with long, recumbent, yellowish hairs; last visible abdominal sternite broadly rounded or subtruncate at apex.

Length 3.5-6 mm., width 2-2.5 mm.

Type locality.-Of anale, Belgaum. Bombay Province, India; type in the Andrewes Collection in the Paris Museum. Of geminatum, Northern China; type was in Schilsky:s Collection in the Zoological Museum in Berlin. Of macleayi, Southern Australia; type probably in South Australian Museum at Adelaide.

Distribution.-This species is distributed throughout India, Ceylon, Mesopotamia, Indo-China, Southern China, Malay Archipelago, Philippines, Australia, Celebes, Java, and New Zealand, and has been carried in commerce to various parts of the world. Many specimens have been examined that were intercepted in wooden packing cases, and in derris and tuba roots at New York: Detroit, Mich.; Philadelphia, Pa.; San Francisco, Calif.; Miami, Fla.; and Columbus, Ohio.

Hosts.-This species is considered to be one of the most destructive wood borers in India. and the adults attack a great variety of plants. Beeson and Bhatia (1937) recorded 67 different plants as the host of this species in India. It is a common species in the forests, timber depots, sawmills, and factories, and is a primary borer in the sapwood of logs, and timbers used in building construction, boxes, and packing cases. The adults tumnel into and oviposit in dying and dead trees, freshly cut logs, firewood, and old, dry, or even rotting (if dry) material, but rarely oriposit in green healthy trees. The adults sometimes bore into green shoots and twigs for feeding or hibernating, and as a result, the leaders of seedlings or young saplings may be killed.

This species was described by Lesne (1897) from material collected at light and under rotten bark. Schilsky (1899) described Sinoxylon geminatum from a single example from Northern China, but Lesne (1906) states that this locality is doubtful and places geminatum as a synonym of $S$. anale Lesne. Blackburn (1859) erected the genus Apatodes for his new species macleayi from southern Australia, but Froggatt (1927) placed it as a synonym of Sinoxylon anale Lesne. 


\section{Sinoxylon COnigerum Gerstäcker}

Sinoxylon conigerum Gerstäcker, 185.5, Mnnatsberichte der Königl. Preuss. Akademie der Wissenschaften zu Berlin, p. 268; Lacordaire, 1857, Genera des Coléopt., v. 4, p. 538; Gerstäcker, 1862, in Peter's' Naturw. Reise noch Mossambique, p. 271, pl. 15, fig. 14; Lesne, 1897, Soc. Ent. de Pelg. Ann. 41: 21; 1906, Soc. Ent. de France Ann. 75: 470, 504-507, fig. 535 ; Lefroy, 1909, Indian Insect Life, p. 317; Stebbing, 1914, Indian Forest Insects, pp. 175-176; Paoli, 1933, Prodv. di Ent. Agr. della Som. Ital., p. 293, fig. 149 (publication not seen) ; Beeson and Bhatia, 1937, Indian Forest Rec. New Ser., Ent. 2 : 229, 291292, 309-320 ; Lesne, 1938, in Junk (pub.), Coleopt. Cat., pt. 161, p. 49.

Body short. Black to dark reddish brown, the antennae, palpi, legs, and abdomen in part, light reddish brown or brownish yellow.

Head with four small tubercles along anterior margin, densely, coarsely granulose, with a few inconspicuous hairs on front, with long, fine, longitudinal, parallel costae on occiput; clypeus finely sparsely granulose, with a transverse, sinuate carina near anterior margin, the carina angulate at middle and extending on each side to tooth at base of labrum; clypeal suture distinct; labrum very finely, densely punctate. Antennal club strongly flabellate, nearly glabrous; first segment of club narrowest, sides nearly parallel; second wider than length of first seven segments united; third finely grooved on anterior margin.

Pronotum slightly wider than long, widest along basal half; sides parallel posteriorly, arcuately converging anteriorly, with a small, unciform tooth at apical angles; posterior angles obtusely rounded; surface sparsely clothed with short, recumbent, inconspicuous hairs, finely, sparsely granulose at sides on basal half, densely, imbricatepunctate at middle on basal half, the imbrications elongate, densely granulose and irregularly dentate on apical half, the teeth broad, semierect, variable in size, and rasplike. Scutellum triangular.

Elytra at base subequal in width to pronotum along basal half; sides sometimes slightly expanded posteriorly, conjointly broadly rounded at apices; submarginal carina following outline of lateral margin, sharply elevated along apical declivity; surface rather sparsely clothed with short, recumbent, yellowish hairs, which are sparser on disk at basal half, densely, coarsely, sometimes confluently punctate; apical declivity arcuately deflexed, not margined anteriorly, with two erect, conical tubercles along sutural margins at middle of declivity, the tubercles narrowly separated, thickened, and dentate at bases, smooth and acute at apices; sutural margins broad, strongly elevated, but not dentate along inner margins between tubercles and apices.

Body beneath densely, finely punctate, densely clothed with long, recumbent, whitish hairs; last visible abdominal sternite broadly rounded or subtruncate at apex.

Length $3.5-6 \mathrm{~mm}$., width $2-2.5 \mathrm{~mm}$.

Type locality.-Of conigerum, Mozambique, Portuguese East Africa. Of unidentatum, East India. Present location of these types is unknown to the writer.

Distribution.-This species is common in India and widespread in the Tropics. The adults are nocturnal and are attracted to lights. It has been recorded from India, East Africa, Madagascar, Ceylon, Java, Philippines, Hawaiian Islands, and Venezuela. Many specimens have been examined that were intercepted at New York in derris roots from 
the Philippines, barbasco stems from Venezuela, ebony logs from Africa, and wooden packing cases from India. So far as known, this species has not become established in the United States.

Hosts.-Beeson and Bhatia (1937) recorded this species as attacking Adina cordifolia, Albizzia cimara, Holoptelea integrifolia, Mangifera indica. Shorea robusta, Terminatia bialata, Terminalia myriocarpa, and Grevia tilicuefolia. They also stated that this species has been recorded damaging lead cables in Hawaii. Lesne (1906) recorded it in the wood of Acacia found in Madagascar.

\section{SiNoxylox Japonicum Lesne}

Sinoxylon japonicum Lesne. 1S95, Soc. Ent. de France Ann. 64: 175-176; 1901, Abeille $30: 111.116$, pl. 4. figs. 102, 103; 1906, Soc. Ent. de France Ann. 75 : 472, 529-530, figs. 545-549; Jakobson, 1913, Käfer Russland, pt. 10, p. 807 ; Lesne, 1935, in Junk (pub.), Coleopt. Cat., pt. 161, p. 50.

Body elongate. Black to reddish brown, elytra usually more reddish, the antennae, palpi, and tarsi brownish yellow.

Head unarmed but declirous along anterior margin, densely, finely granulose and sparsely clothed with long. erect, inconspicuous hairs on front, with long, fine, longitudinal, parallel costae on occiput; clypeus flat, densely, finely granulose. with a rague, transverse, sinuate carina near anterior margin extending on each side to tooth at base of labrum: clypeal suture distinct: labrum finely, densely punctate. Antennal club not flabellate, but segments strongly transrerse, densely clothed with rery short, recumbent, vellowish hairs: first segment of club subtriangular, twice as wide as long: second slightly wider than first. not as wide as length of first seven segments united: third oblong.

Pronotum slightly wider than long, widest at middle; sides broadly rounded, more strongly converging anteriorly, with a small, unciform tooth at apical angles; posterior angles broadly rounded; surface rather densely, irregularly clothed with whitish hairs. which are short and recumbent on basal half, much longer and erect near anterior margin, rather sparsely, finely granulose on basal half. densely granulose and irregularly dentate on apical half, the teeth broad. semierect. variable in size. and rasplike. with three or four larger ones on each side along lateral margin. Scutellum quadrate.

Elytra at base subequal in width to pronotum at middle; sides nearly parallel, conjointly broadly rounded at apices: submarginal carina following outline of lateral margin, sharply elerated along apical declivity: surface rather densely clothed with short. recumbent. yellowish hairs. densely. coarsely. irregularly punctate, the punctures more or less confluent on apical declivity : apical declivity arcuately deflexed, not margined anteriorly, each elytron with a small. transverse gibbosity near lateral margin. and a long. erect. conical tubercle near middle of declivity, the tubercle rugose. finely pubescent. obtuse at apex, placed some distance from sutural margin but connected to it by a rague. transverse carina; sutural margins feebly, broadly elerated and finely dentate on apical declivity.

Body beneath finely, densely punctate, densely clothed with long. recumbent and erect. vellowish-white hairs; last visible abdominal sternite broadly rounded or subtruncate at apex.

Length $5-6$ mm.. width $2-2.5 \mathrm{~mm}$.

Type locality.-Japan; type in the Paris Museum. 
Distribution.-This species has been recorded only from Japan. There is a single specimen in the United States National Museum Collection taken in a wooden packing case from Japan, September 16 , 1936 , by W. F. Clapp. So far this species has not become established in the United States.

Hosts.-Nothing has been recorded on the habits of this species.

Lesne described this species from five specimens, all of which he designated as types.

\section{SinOXYLON RUFicorne Fåhraeus}

Sinoxylon ruficorne Fåhraeus, 1872, Öfvers. Vetensk. Akad. Förhandl. 28 (1871) : 665-666; Lesne, 1906, Soc. Ent. de France Ann. 75: 471, 513-517, figs. 540-541; Lounsbury, 1915, Bul. Ent. Res. 6 : 201 ; Lesne, 1924, Bostrychides de l'Afrique Tropicale Française, pp. 177, 180-183, figs. 111-112; 1938, in Junk (pub. ), Coleopt. Cat., pt. 161, p. 52 ; Tooke and Scott, 1944, So. Africa Dept. Agr. and Forestry Bul. 247 (Ent. Ser. 14) : 7, 11-12, fig. 12.

Body short. Black to dark reddish brown. antennae, palpi, and tarsi yellowish to pale reddish brown.

Head with four small, distinct tubercles along anterior margin, coarsely, sparsely punctate and sparsely clothed with short, semierect and recumbent, inconspicuous hairs on front, with long, fine, longitudinal, parallel costae on occiput; clypeus flat, sparsely, finely granulose, sparsely clothed with short, semierect hairs; clypeal suture distinct at middle, obsolete at sides; labrum indistinctly punctate. Antennal club not flabellate, but segments strongly transverse, densely clothed with very short, recumbent, yellowish hairs; first segment of club subtriangular, twice as wide as long; second slightly wider than first, about as wide as length of first seven segments united; third oblong.

Pronotum slightly wider than long, widest along basal half; sides parallel along basal half, arcuately converging anteriorly, with a small, unciform tooth at apical angles; posterior angles obtusely rounded; surface rather densely clothed with short, recumbent, yellowish hairs, sparsely, finely granulose on basal half, densely granulose and irregularly dentate on apical half, the teeth broad, semierect, variable in size, and rasplike, and with four or five larger tubercles on each side along lateral margin.

Elytra at base subequal in width to pronotum along basal half; sides slightly expanded posteriorly, conjointly broadly rounded at apices; submarginal carina following outline of lateral margin, sharply elevated along apical declivity; basal margin thickened and densely, finely tuberculate; surface rather densely clothed with very short, recumbent, yellowish hairs, coarsely, densely, irregularly punctate, the punctures more or less confluent on apical declivity; apical declivity obliquely deflexed, each elytron with three costiform tubercles at top of declivity, and a long, smooth, erect, slightly divergent, triangular tubercle near middle of declivity, the tubercle placed at inner edge of sutural margin, compressed laterally, slightly concave on inner surface, acute at apex, and at bottom connected to sutural margin by a vague, transverse carina; sutural margins broadly strongly elevated on apical declivity, with inner margins crenulate.

Body beneath finely, densely punctate or rugose, densely clothed with long, recumbent, yellowish hairs; last visible abdominal sternite broadly rounded or subtruncate at apex. 
Length $\check{0}-7 \mathrm{~mm}$., width $2-3 \mathrm{~mm}$.

Type locality.-Caffraria, Southern Africa; type in either the Stockholm or the Göteberg Museum.

Distribution.-Recorded throughout all of tropical and southern Africa. A good series of adults was intercepted at New York. December 3, 1941, in Dalbergia melanoxylon logs from Mozambique, Portuguese East Africa. So far as known, the species has not become established in the United States.

Hosts.-Lesne (1924) recorded the adults making burrors during September and October in the small branches of casuarines and also in the wooden pickets of "Mopasie" used in the construction of the native huts. Lounsburg (1915) recorded the species as boring into the lead-covered aerial cables in the Union of South Africa. Tooke and Scott (1944) reported it as a frequent borer in Eucalyptus and Acacia, and probably attacking logs of all the Leguminosae. Although this species is primarily a borer in the sapwood of logs, the adults sometimes bore into the green shoots and twigs of Acacia to feed, and frequently kill the leaders of seedlings and young saplings.

\section{Sinoxylon SEXDENTATUM (Olivier)}

Bostrichus sexdentatum Olivier, 1790, Encyc. Méthodique, Insects, v. 5, pp. 107, 110; 1795, Entomologie, r. 4, Gen. 77, pp. 12-13, pl. 1, figs. 3a-b.

A pate sexdentatum Perris, 1850, Soc. Enit. de France Ann. (ser. 2) 8: 559-562, pl. 16, figs. 9-11.

Sinoxylon sexdentatum Jacquelin-Dural, 1859-1863, Genera Coléopt. Europe, f. 3 , pl. 56, fig. 27 ; Kiesenwetter, 187 Deut., Coleopt., r. 5, pt. 1, pp. 33-34; Rey, 1897, Lyon Soc. Linn. Ann. (ser. 2) 33 (18S6) : 220; Zoufal, 1894, Wien. Ent. Ztg. 13: 37; Schilskr, 1899, in Küster and Kraatz, Käfer Europas, 36, No. S3; Lesne, 1901, Abeille $30: 111$, 113-114, pl. 4, figs. 97, 98; 1906, Soc. Ent. de France Ann. 75: 472. 51s-524, figs. 543-544; Reitter, 1911, Fauna Germanica 3 : 305; Jakobson, 1913, Käfer Russland, pt. 10, p. 807, pl. 44, fig. 11; Balachowsky, 1935, Insectes Nuisibles aux Plantes Cultivées, pp. 645-650; Lesne, 1935, in Junk (pub.), Coleopt. Cat., pt. 161, pp. 52-53.

Synoxylon sexdentatum Perris, 1Sт7, Larres de Coléoptères, p. 219.

Apate bidens Fabricius, 1798, Entomologia Srstematica, Sup., p. 157; 1801, Systema Eleuthelatorum, r. 2, p. 381.

The above-mentioned list of citations is not complete, only a few of the more important ones being giren.

Body short. Black, except elytra, antennae, palpi, and tarsi, which are reddish brown or brownish yellow.

Head unarmed along anterior margin, finely, densely granulose, and sparsely clothed with long, recumbent, whitish hairs on front, with long, fine, longitudinal, parallel carinae on occiput; clypeus densely, finely granulose, longitudinally carinate at middle, with a transverse, sinuate carina near anterior margin extending on each side to tooth at base of labrum; clypeal suture distinct at middle. more or less obsolete toward sides; labrum finely, densely punctate. Intennal club not flabellate, but segments strongly transverse, sparsely clothed with short, recumbent, inconspicuous hairs, with distinct yellow pubescent spots; first segment of club subtriangular. twice as wide as long; second subtriangular, slightly wider than first, not as wide as length of first seven segments united; third oblong.

Pronotum slightly wider than long, widest at middle: sides broadly rounded, more strongly converging anteriorly, with a small, unciform tooth at apical angles; posterior angles broadly rounded; surface 
sparsely, irregularly clothed with long, erect and recumbent, whitish hairs, sparsely granulose on basal half, the granules elongate on median area, densely granulose and irregularly dentate on apical half, the teeth broad, semierect, variable in size, and rasplike, especially on top of disk, and with three to four larger tubercles on each side along lateral margin. Scutellum triangular.

Elytra at base subequal in width to pronotum at middle; sides slightly expanded posteriorly, conjointly broadly rounded at apices; submarginal carina following outline of lateral margin, sharply elevated along apical declivity; surface rather densely, irregularly clothed with erect, arcuate, yellowish or whitish hairs, which are denser and much longer toward sides, coarsely, densely, irregularly punctate, the punctures somewhat finer near apices; apical declivity arcuately deflexed, not margined anteriorly, each elytron with a costiform tubercle at top of declivity, and two smooth, erect tubercles placed transversely at middle of declivity, the inner tubercle long, slightly divergent, acute at apex, placed some distance from sutural margin, outer tubercle short, obtuse at apex; sutural margins not elevated on apical declivity.

Body beneath finely, densely punctate, rather densely clothed with long, recumbent and semierect, whitish hairs; last visible abdominal sternite broadly rounded or subtruncate at apex.

Length $3.5-6 \mathrm{~mm}$., width $1.75-2.5 \mathrm{~mm}$.

Type locality.-Of sexdentatum, Provence, France; present location of type is unknown to writer. Of bidens, Tangier, Morocco; type in the Copenhagen Museum.

Distribution.-This species is distributed throughout the greater part of the Mediterranean region, both in Europe and Africa. Specimens were intercepted at New York, October 20, 1941, and January 29,1946 , in wooden slats around bundles of cork from Portugal. So far as known, this species has not become established in the United States.

Hosts.-The larvae of this species live in the dead and dying branches of various nonconiferous trees, but in France and Italy prefer the fig and grape. The species has also been recorded in mulberry, locust, olive, clematis, rose, ivy, chestnut, peach, pear, elm, Quercus ilex, Acacia dealbata, Acacia eburnea, Paliurus aculeatus, and Arundo donax.

Olivier (1790) described sexdentatum from specimens collected in grape wood. Fabricius (1798) described bidens from Tangier. Lesne (1901), on the basis of Meinert's comparison of a specimen of sexdentatum Olivier with the type of bidens Fabricius in the $\mathrm{Mu}-$ seum at Copenhagen, placed bidens Fabricius (1798) as a synonym of sexdentatum Olivier (1790).

\section{Genus BOSTRYCHOPLITES Lesne}

Bostrychoplites Lesne, 1899, Soc. Ent. de France Ann. (1898) 67 : 443, 565-581; Schilsky, 1899, Käfer Europas 36: p. UU ; Lesne, 1901, Abeille $30: 87,96-97$; Jakobson, 1913, Käfer Russland, pt. 10, pp. 803, 806 ; Lesne, 1924, Bostrychides de l'Afrique Tropicale Française, pp. 114, 148-169; 1938, in Junk (pub.) Coleopt. Cat., pt. 161, pp. 43-14.

Head strong convex on occiput, broadly, deeply, transversely concave behind eyes, deeply inserted in prothorax, not visible from above; clypeus convex, broadly transverse, broadly emarginate in 
front, anterior angles more or less acute and projecting, embracing sides of labrum; clypeal suture distinct or obsolete; labrum short, strongly transverse, truncate and densely ciliate with long, yellow hairs in front; margins of buccal cavities dentate below eyes; mandibles more or less attenuate toward apices; eyes round, globose, strongly projecting. Antenna short, 10-segmented, first and second segments robust, elongate, second shorter than first; third to seventh segments short, oral, becoming transrerse toward serenth, subequal in length to one another; last three segments forming a broad, loose, compressed club, with more or less distinct round, sensory depressions on each surface, the segments subequal in length to one another, the eighth and ninth transverse, truncate at apices, tenth oblong, narrower than ninth.

Pronotum strongly convex, emarginate in front, truncate at base, dentate anteriorly, not transversely depressed belind anterior margin: sides not margined. Scutellum small, quadrate. Elytra strongly convex, with or without longitudinal costae, without distinct tubercles on apical declivity. Legs short, subequal in length; tibia slightly expanded toward apices, anterior and middle pairs dentate on exterior margins, each with a large, arcuate spine at apex; posterior tarsi as long as or longer than tibiae, apical segment of each shorter than preceding four segments united. Anterior coxae contiguous. Middle coxae rather broadly separated. Posterior coxal cavities completely margined on first visible abdominal sternite. Intercoxal process of abdomen tubular or narrowly triangular. Body elongate, cylindrical.

Genotype.-Bostrichus cornutus Olivier. (Present designation.)

Lesne (1899) erected the genus Bostrychoptites for 11 African species without designating a genotype.

\section{Bostrychoplites CORNutus (Olivier)}

Bostrichus cornutus Olirier, 1790, Ency. Méthodique, Insectes, v. 5, pp. 106, 108; 1775, Entomologie, r. 4, Gen. 77, p. 7, pl. 1, figs. 5a-b-c; Få̆raeus, 1872, Öfrers. Vetensk. Akad. Förhandl. 28 (1S71) : 668.

Apate cornutus Fabricius, 1792, Ent. System., v. 1, pt. 2, p. 360; Herbst, 1793, Natursystem Insekten Käfer, v. 5, pp. 72-73; Fabricius, 1801, Systema Eleutheratorum, v. 1, p. 380 .

Bostrychoplites cornutus Lesne, 1899, Soc. Ent. de France Ann. (189S) 67:568, 572-573; figs. 34, 17S, 181, 185-1ST; 1924, Bostrychides de l'Afrique Tropicale Française, pp. 150, 156-158, figs. 16. S8-90; 1938; in Junk (pub.), Coleopt. Cat., pt. 161, p. 43; Tooke and Scott, 1944, So. Africa Dept. Agr. and Forestry, Bul. 247 (Ent. Ser. 14) : 6, fig. 3.

Apate destructor Burchell, 1822, Trarels in the Interior of South Africa, 5.1 , p. 325 (publication not seen).

Male.-Black to dark reddish brown, the palpi, antennae, and tarsi more reddish brown.

Head much narrower than pronotum, coarsely, irregularly punctate anteriorly, coarsely granulose and with short, longitudinal costae on occiput, sparsely clothed with short, semierect. whitish hairs anteriorly and on clypeus. with a few long, erect hairs intermixed; clypeus uneven, coarsely granulose, broadly, transversely flattened and smooth at middle, anterior angles acute; clypeal suture indicated at middle, obsolete at sides.

Pronotum (not including apical horns) slightly transverse, widest along apical half, strongly deflexed anteriorly, with a narrow, longi- 
tudinal, median, smooth line, sometimes extending from base to apex; sides arcuately converging posteriorly, parallel anteriorly, produced into a long, slightly arcuate horn at apical angles, the horn not hooked at apex; posterior angles rounded or rectangular; surface densely, coarsely, uniformly granulose, with a few large erect tubercles anteriorly and on apical horns, sparsely, uniformly clothed with very short, semierect, whitish, scalelike hairs, with numerous very long, erect, yellowish hairs on apical declivity and along anterior margin.

Elytra at base slightly narrower than pronotum along apical half, slightly sinuate at base; sides nearly parallel, conjointly broadly rounded at apices, the margins finely granulose posteriorly; surface densely, coarsely, irregularly punctate, rugose or coarsely granulose on intervals, sparsely, uniformly clothed with very short, recumbent, whitish, scalelike hairs. Each elytron with five more or less distinct, crenulate, longitudinal costae; first and second distinct, extending from base to near apex; third and fourth more or less obsolete; fifth extending along lateral margin from base to apex, thickened and strongly elevated along apical fifth.

Body beneath rather densely clothed with short, semierect, yellowish hairs; abdomen coarsely, densely, uniformly granulose; mesosternum and metasternum densely, coarsely, irregularly punctate. Anterior coxal cavities closed posteriorly.

Female.-Differs from the male in having the pronotum slightly narrower or subequal in width to the elytra, the clypeus not distinctly flattened at the middle, and the front of the pronotum not clothed with long, erect yellow hairs.

Length 6.5-17 mm., width 1.75-5.5 mm.

Type locality.-Bourbon Island; location of type unknown to writer.

Distribution.-This species is distributed throughout all parts of Southern and Tropical Africa, Western Arabia, Madagascar, and the Mascarene, Comoro, and Bourbon Islands. A single specimen was collected at St. Albans, Vt., September 20, 1939, with hazelnuts from Canada.

Hosts.-Burchell (1822) recorded this species burrowing in the dead limbs of Acacia along the Orange River, in Griqualand, Africa. Lesne (1924) recorded it in Euphorbia intisy. Tooke and Scott (1944) reported this species as attacking bamboo, and $\operatorname{logs}$ and poles of eucalyptus, particularly Eucalyptus saligna.

The adults of cornutus are nocturnal and are commonly found only after sundown. There is a specimen of cornutus in the Dejean Collection labeled A pate destructor Burchell.

\section{Genus AMPHICERUS LeConte}

Amphicerus LeConte, 1861, Smithsn. Inst. Misc. Collect. 3 (1) : 208; Horn, 1878, Amer. Phil. Soc. Proc. 17: 541, 546-548; LeConte and Horn, 1883, Smithsn. Inst. Misc. Collect. 507 : 228; Casey, 1898, N. Y. Ent. Soc. Jour. 6 : 66, 68-70 ; Lesne, 1899, Soc. Ent. de France Ann. (1898) 67: 502 ; 1937, Soc. Ent. de France Bul. 42: 238; 1938, in Junk (pub.), Coleopt. Cat., pt. 161, pp. $40-42$.

Caenophrada Waterhouse, 1888, Ann. and Mag. Nat. Hist. (ser. 6) 1: 350.

Schistoceros Lesne, 1899, Soc. Ent. de France Ann. (1898) 67: 442, 502-524; Schilsky, 1899, in Küster and Kraatz, Käfer Europas 36: p. TT; Lesne, 1901, Abeille 30:86, 92-93, pl. 1, fig. 28; Csiki, 1903, Rov. Lapok. 10: 18, 19; Reitter, 1911, Fauna Germanica, v. 3, p. 301; Jakobson, 1913, Käfer Russland, 
pt. 10 , pp. 803,805 ; Lesne, 1924, Bostrychides de l'Afrique Tropicale Française, pp. 114, 131-133; Gardner, 1933, Indian Forest Rec., Ent. Ser. 18 (9) : 13-14, pl. 4, figs. 43-41.

Head slightly convex on rertex, flattened or transrersely concare behind eves. deeply inserted in prothorax, not visible from above; clypeus long, strongly transverse, flattened, broadly, shallowly, arcuately emarginate in front, anterior angles acute; clypeal suture obsolete or distinct at middle; labrum short, strongly transrerse, subtruncate and densely ciliate with long, yellow hairs in front; margins of buccal carities not dentate below eyes; mandibles more or less attenuate toward apices; eves round or oral, sometimes globose. strongly projecting. Antenna short, 9- or 10-segmented: first and second segments robust, elongate, second shorter than first: third to sixth or serenth segments short. round or transverse, sometimes narrower than second, subequal in length to one another; last three segments forming a broad, loose, compressed club, each segment with two or three long, sensory depressions on each surface, the first and second segments of club usually subequal in length to each other, round, subquadrate or subtriangular. apical segment oblong or oval. Rarely with a 2-segmented club. Pronotum strongly convex, truncate at base, truncate, rounded, or emarginate in front, dentate anteriorly, not transversely depressed behind anterior margin: sides not margined; posterior angles rounded. Scutellum small, quadrate. Elytra strongly convex, abruptly declivous posteriorly. with or without tubercles on apical declivity. Legs short. subequal in length; tibiae expanded toward apices, usually dentate on exterior margins, anterior pair with a large, arcuate spine at apices; posterior tarsi as long as, or longer than tibiae, apical segment of each shorter than preceding four segments united. Anterior coxae contiguous. Middle coxae narrowly separated. Posterior coxal cavities completely margined on first visible and abdominal sternite. Intercoxal process of abdomen tabular or narrowly triangular. Body elongate. cylindrical.

Genotype.-Of Amphicerus. Apate bicaudatus Say. (Present designation.) Of Caenophrada, Caenophrada anobioides Waterhouse. (Monobasic.) Of Schistoceros, Bostrichus bimaculatus Olivier. (Present designation.)

LeConte (1861) erected Amphicerus for Apate bicaudatus Say. Apate aspericollis Germar. and Bostrichus punctipennis LeConte. without designating a genotype.

Waterhouse (1888) erected the genus Caenophrada for his new species anobioides from North India, but Lesne (1938) placed it as a swnonym of Amphicerus.

Lesne (1899) erected Schistoceros for 11 species without designating a genotype. Lesne stated that Amphicemus LeConte was preoccupied by Amphicerus Gray (1847) in the mollusks and suppressed it under his new genus Schistoceros. In 1937, however, he reversed his decision, but divided the genus into two subgenera, conserving the name Amphicerus for the species in which both sexes have the horns of the prothorax, and Schistoceros for those in which the females or both sexes have the prothorax rounded and unarmed at the anterior margin.

The species of this genus are distributed throughout North. Central. and South America, Mexico, West Indies, Hawaii, Indo-China, India, Malaysia, Arabia, and the Mediterranean Region. 


\section{KEY TO THE SPECIES OF AMPHICERUS}

1. Prothorax armed with horns in both sexes _ subgenus Amphicerus LeConte Prothorax not armed with horns in both sexes__ subgenus Schistoceros Lesne

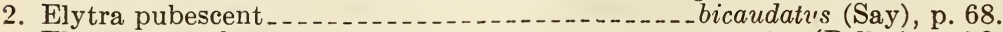
Elytra not pubescent. ...................... cornutus (Pallas), p. 70.

3. Pronotum with a large patch of dense white pubescence, concealing the surface at each side on basal half _. . . . . _. bimaculatus (Olivieri, p. 72.

Pronotum without a large patch of dense white pubescence on each side..-

4. Front of head with long, erect hairs; elytra with long, erect hairs over entire surface; pronotum not distinctly expanded toward base

teres Horn, p. 73.

Front of head without long, erect hairs; elytra without long, erect hairs, but with a few short ones along lateral margins and at apices; pronotum strongly expanded toward base .............. simplex (Horn), p. 74.

\section{Amphicerus (Amphicerus) bicaudatus (Say)}

Apate bicaudatus Say, 1824, Acad. Nat. Sci. Phila. Jour. $3:$ 320-321.

Bostrichus bicaudatus Fitch, 1856, N. Y. State Agr. Soc. Trans. 16: 330 ; Walsh and Riley, 1868-1869, Amer. Ent. 1: 80, 206, figs. 69, 141; Walsh, 1866, Pract. Ent. 1 : 27, fig. ; Riley, 1872, Ins. Missouri, Rpt. 4, pp. 51, 53, figs. 24-25; 1873, ibid., Rpt. 5, p. 54.

Amphicerus bicaudatus Shimer, 1868, Amer. Ent. Soc. Trans. 2: Proc. pp. VIIIIX; Horn, 1878, Amer. Phil. Soc. Proc. 17: 547-548; Saunders, 1883, Insects Injurious to Fruits, pp. 33-35, figs. 21-22 ; Hubbard, 1888, Ent. Amer. 4: 95-96; Lintner, 1896, N. Y. State Mus., Rpt. 49 (1895), p. 268; Casey, 1898, N. Y. Ent. Soc. Jour. 6: 69; Marlatt, 1898, U. S. Dept. Agr., Farmers' Bul. 70, pp. 11-16, fig. 6 ; Blatchley, 1910, Coleoptera of Indiana, pp. 889-890; Leonard, 1928, N. Y. (Cornell) Agr. Expt. Sta., Mem. 101: 415; Brimley, 1938, Insects of North Carolina, p. 197.

Schistoceros hamatus Lesne, 1899 (not Fabricius), Soc. Ent. de France Ann. (1898) 67: 506, 513-517, figs. 48, 106, 117; Quaintance and Shear, 1921, U. S.

Dept. Agr., Farmers' Bul. 1220, pp. 38-39, figs. 39-10.

Amphicerus hamatus Lesne, 1938 (not Fabricius), in Junk (pub.), Coleopt. Cat., pt. 161, p. 41; Anderson, 1939, Wash. Acad. Sci. Jour. 29 (9) : 390, fig. 24 (larvae); Belkin, 1940, Ent. News 51: 193.

Amphicerus gracilis Casey, 1898, N. Y. Ent. Soc. Jour. 6: 68-69 ; Lesne, 1938, in Junk (pub.), Coleopt. Cat., pt. 161, p. 41; Brimley, 1938, Insects of North Carolina, p. 197. (New synonymy.)

Apate serricollis Germar, 1824, Insectorum Species Novae, v. 1, p. 464; Chevrolat, 1861, Soc. Ent. de France (ser. 4) 1:392.

Apate aspericollis Germar, 1824, Insectorum Species Norae, v. 1, p. 465.

Citations to the literature are not complete; only the more important ones have been given.

Male.-Elongate, cylindrical, uniformly reddish brown to brownish black, the antennae, palpi, and legs slightly paler; dorsal surface of body sparsely clothed with short, recumbent, yellowish hairs.

Head much narrower than pronotum, transversely flattened behind eyes, smooth at middle of flattened area, finely, irregularly granulose, with a few larger granules and dense, long, erect hairs on front and clypeus, and with short, longitudinal, parallel carinae on occiput; clypeal suture slightly indicated, sometimes obsolete at sides; labrum finely, densely punctate; first segment of antennal club quadrate.

Pronotum quadrate, arcuately emarginate in front, widest at middle, strongly deflexed anteriorly; sides broadly rounded, produced into a short, unciform horn at apical angles; surface densely, coarsely imbricate-punctate on basal half, densely, coarsely tuberculate on apical half, the tubercles broad, semierect, and rasplike, with four large rasp- 
like tubercles on each side along lateral margin. Scutellum densely clothed with short, yellowish hairs.

Elytra at base subequal in width to pronotum at middle, truncate at base, each elytron with a large, arcuate spine or tubercle at top of apical declivity, the tubercles turned inward toward sutural margins; sutural margins slightly elevated on apical declivity; sides parallel, conjointly broadly rounded at apices, the margins thickened and elevated toward apices; surface coarsely, irregularly, more or less confluently punctate.

Body beneath finely, densely punctate, with a few large punctures intermixed on abdomen, densely, uniformly clothed with short, recumbent, yellowish-white hairs, with a few long, erect, yellowish hairs on abdominal sternites.

Female.-Differs from the male in having a vague costiform callosity on each elytron at the top of the apical declivity.

Length 6-11.5 mm., width 1.2-3.5 mm.

Type locality.-Of bicaudatus, above the mouth of the Ohio River. Since the type of this species is lost, the writer is designating a male specimen in the United States National Museum labeled "Charleston, Mo.," collected in a trap lantern, April 18, 1917, by A. F. Satterthwait, as neotype. Of serricollis and aspericollis, Kentucky; present location of types unknown to writer. Of gracilis, Kansas; type in the Casey Collection in the United States National Museum.

Distribution.-This species is distributed throughout southeastern Canada and the greater part of the United States east of the Rocky Mountains. Specimens have been examined from Alabama, Arkansas, Colorado, District of Columbia, Florida, Indiana, Iowa, Kansas, Kentucky, Louisiana, Maryland, Michigan, Mississippi, Missouri, Nebraska, New Jersey, New York, North Carolina, Ohio, Oklahoma, South Carolina, Tennessee, Texas, Virginia, and West Virginia.

Hosts.-Marlatt (1898) and Quaintance and Shear (1921) recorded bicaudatus as breeding in dying wood, such as large prunings, exposed roots of maple, and diseased and dying branches of most shade and fruit trees. Hubbard (1888) observed the larvae in the underground stems or roots of a species of Smilax at Crescent City, Fla. So far as is known it will not breed in old, dry wood or in vigorous live growth, but seems to need wood in a dying or diseased condition. The adults have been recorded as attacking living twigs or small branches of white ash, butternut, pecan, hickory, pear, apple, apricot, plum, peach, cherry, and grape. Injuries by this species seem to be confined to the adults, which bore into the live twigs immediately above a bud. Undoubtedly this boring is partly for food, and certainly has nothing to do with egg laying. The injury to grape canes and apple twigs results in the wilting and dying of the adjacent shoots, and in some cases grapevines have been killed during the early spring months.

Horn (1878) suggested that Apate hamatus described by Fabricius ${ }^{5}$ from Saxony, might by chance be the species described by Say (1824) from America as Apate bicaudatus. Lesne (1899) suppressed bicaudatus Say as a synonym of hamatus Fabricius, without giving

${ }^{5}$ Fabricius, J. C. MANTISSA INSECtorUm, v. 5, p. 33. 1787. 
any explanation, perhaps on the above suggestion by Horn. Prior authors, Olivier, ${ }^{6}$ Fabricius, ${ }^{7}$ and Herbst ${ }^{8}$ all cite Fabricius (1787) and give the habitat as Saxony. After these dates no mention was made of hamatus until Horn (1878) cited it as synonymous with bicaudatus, and was followed by Lesne (1899). Other than the type locality, no European record of hamatus has been published, and use of this name for the North American species seems unwise until the type can be critically restudied.

Germar (1824) described serricollis ( $\hat{o}$ ) and aspericollis ( $q$ ), both from Kentucky, but both species have been placed as synonyms of bicaudatus. Casey (1898) based his description of gracilis on four specimens from Kansas, Iowa, and North Carolina, but after studying these types, the writer is unable to separate gracilis from bicaudatus.

In this species the normal number of segments in the antenna is 10 , with a 3-segmented club, but the number of segments is variable. The antenna is composed of either 8, 9, or 10 segments, in which case the club is either 1-, 2-, or 3-segmented, and sometimes the number of segments varies on the two antennae.

\section{Amphicerus (Amphicerus) cornutus (Pallas)}

Ligniperda cornuta Pallas, 1772, Spicilegia Zoologica, v. 1, pt. 9, p. 8, pl. 1, fig. 4. Bostrychus cornutus Lesne, 1896, Soc. Ent. de France Bul., p. 334.

Schistoceros cornutus Lesne, 1899, Soc. Ent. de France Ann. (1898), 67: 506, 510-513, figs. 105, 110-113, 115; 1910, Paris Mus. d'Hist. Nat. Bul. 16: 185-186. Amphicerus cornutus Lesne, 1938, in Junk (pub.), Coleopt. Cat., pt. 161, pp. 40-41; 1939, Rev. Franç. Ent. 6: 91, 97; Anderson, 1939, Wash. Acad. Sci. Jour. 29 (9) : 390, figs. 23, 29, 34 (larvae) ; Brimley, 1938, Insects of North Carolina, p. 197 ; Belkin, 1940, Ent. News 51: 193.

Ligniperda ( ?) bicornutus Latreille, 1833, Voy. Humboldt, v. 2, p. 65, pl. 34, fig. 6 (publication not available).

Apate punctipennis LeConte, 1858, Acad. Nat. Sci. Phila. Proc. 10: 73; Gorham, 1883, Biol. Centr-Amer., Coleopt. 3 (2) : 213 ; Herbert, 1920, Jour. Econ. Ent. 13 : 361.

Amphicerus punctipennis Horn, 1878, Amer. Phil. Soc. Proc. 17: 547 ; Hubbard, 1888, Ent. Amer. 4: 95-96; Coquillett, 1892, Insect Life 4: 261; Casey, 1898, N. Y. Ent. Soc. Jour. 6: 68; Marlatt, 1898, U. S. Dept. Agr. Farmers' Bul. 70, p. 12.

Bostrichus peregrinus Erichson, 1847, in Wiegmann's Arch. f. Naturgesch. 13 (1) : 87.

Schistoceros peregrinus Lesne, 1899, Soc. Ent. de France Ann. (1898) 67: $620-621$.

Bostrichus migrator Sharp, 1885, Roy. Dublin Soc. Sci. Trans. (ser. 2) 3:160 161 ; Gorham, 1886, Biol. Centr.-Amer., Coleopt. 3, pt. 2 : 352.

Amphicerus maritimus Casey, 1898, N. Y. Ent. Soc. Jour. 6: 68; Lesne, 193S, in Junk (pub.), Coleopt. Cat., pt. 161, p. 41. (New synonymy.)

Male.-Elongate, cylindrical, uniformly brownish black, the antennae and palpi reddish brown.

Head much narrower than pronotum, transversely concave behind eyes, finely granulose and rugose, densely clothed with long, semierect, yellowish hairs, and with two small tubercles at middle behind clypeus, smooth and shining at middle of transverse concave area, and with short, longitudinal, parallel carinae on occiput; clypeus coarsely punctate, finely, sparsely granulose; clypeal suture deeply impressed at

\footnotetext{
${ }^{6}$ Oltvier, A. G. encyclopedie méthodique, insectos, v. 5, p. 108, 1790.

' FABricius, J. C. ENTOMologica systematica, v. 1, pt. 2, pp. 360-361, 1792; SYSTEMA ELUTHERATORUM, v. 2, pp. 380-381, 1801.

${ }^{8}$ Herbst, N. M. NATURSystem insekten, Käfer, v. 5, p. 73, 1793.
} 
middle. obsolete at sides; labrum finely, densely punctate; first segment of antennal club quadrate.

Pronotum quadrate, arcuately emarginate in front, widest along middle. strongly deflexed anteriorly; sides broadly rounded, more strongly converging anteriorly, produced into a rather large unciform horn at apical angles: surface densely, coarsely imbricate-punctate on basal half, densely tuberculate on apical half, the tubercles broad. semierect, and rasplike. with four or five large rasplike tubercles on each side along lateral margin, sparsely clothed with short, semierect, vellowish hairs on apical half. Scutellum densely clothed with short. rellowish hairs.

Elytra at base subequal in width to pronotum at middle, truncate at base, each elytron with two costiform tubercles at top of apical declivity: sutural margins slightly elevated on apical declirity; sides parallel. conjointly broadly rounded at apices, the margins strongly elerated torard apices; surface glabrous, coarsely, rather densely, irregularly punctate.

Body beneath densely clothed with rather long, recumbent, yellowish hairs; abdomen finely, densely punctate, with numerous large punctures intermixed.

Female.-Differs from the male in having the apical horns on the pronotum smaller, and without or with only vaguely indicated costiform callosities on the apical declirity of the elytra.

Length $8.5-14 \mathrm{~mm}$., width $2.7-5 \mathrm{~mm}$.

Type locality.-Of cornutus, Jamaica; type was in the Berlin Museum. Of bicornutus, original publication not arailable. Of punctipennis. Texas, California. and Sonora, Mexico; types in the LeConte Collection in the Museum of Comparative Zoology, Cambridge. Mass. Of peregrinus. Peru: type mas in the Berlin Museum. Of migrator. Nicaragua and Sandwich Islands; type in the British Museum. Of maritimus, Galveston. Tex.; type in the Casey Collection in the United States National Museum.

Distribution.-Specimens have been examined from many localities in Arizona. California, Colorado, Utah, Texas, New Mexico. Florida. Lower California. North Carolina, Mexico. Nicaragua, Costa Rica. Colombia. Venezuela. Peru. Ecuador. Cuba, Puerto Rico. Antigua. and the Hamaiian Islands. It has been reported also from Brazil. Guatemala. Panama. Guadeloupe. Jamaica. and the St. Thomas and St. Martin Islands. It has been introduced into the Hawaiian Islands, where it has become acclimated.

Hosts.-Herbert (1920) stated that mesquite appears to be the natural host plant of this species. The species has been recorded as burrowing in apricot. peach. fig. grape, pear. orange. pecan, locust, wild cotton, bamboo, Vachellia farnesiana, Merostachys racemiflora, and dry Arthrostylium longifotium used as sheathing on a roof of a honse in Mexico. Hubbard (1858) recorded finding adults of this species in the half-burned roots of Smilax at Key West, Fla.

Pallas (1772) described cornuta from a female from Jamaica, and Latreille (1833) described the male of the same species under the name of bicornutus. Lesne in 1896 placed bicormutus as a synonym of cornutus, and in 1899 also placed peregrinus Erichson (isti). migrator Sharp (1885), and punctipennis LeConte (1855) as synonyms of cornutus Pallas (1772). After examining the type of Amphicerus mari- 
timus Casey (1898) I am unable to find any constant characters for separating it from cornutus.

\section{Amphicerus (Schistoceros) bimaculatus (Olivier)}

Bostrichus bimaculatus Olivier, 1790, Encyc. Méthodique, Insectes, v. 5, pp. 107, 109-110; 1795, Entomologie, ,. 4, Gen. 77, pp. 10-11, pl. 2, figs. 14a-b; Kiesenwetter, 1877, in Erichson, Naturgesch. Insect. Deut. Coleopt., v. 5, pt. 1, p. 37.

Bostrychus bimaculatus Zoufal, 1894, Wien. Ent. Ztg. 13: 41.

Apate bimaculatus Herbst, 1793, Natursystem Insekten, Käfer, v. 5, p. 75 ; Jacquelin-Duval, 1859-1863, Genera Coléopt. Europe, จ. 3, Cat. p. 167, pl. 56, fig. 279 ; Perris, 1877, Larves Coléoptères, p. 219; Rey, 1887, Lyon Soc. Linn. Ann. (1886) (ser. 2) 33:219-220.

Schistoceros bimaculatus Lesne, 1899, Soc. Ent. de France Ann. (1898) 67: 508, 520-522, figs. 128-131; Schilsky, 1899, in Küster and Kraatz, Käfer Europas 36 : No. 86 ; Lesne, 1901, Abeille $30: 93$, pl. 2, figs. 36-38; Csiki, 1903, Rov. Lapok. 10: 19 ; Semenov, 1903, Rev. Russe d'Ent. 3: 402 ; Reitter, 1911, Fauna Germanica, v. 3, p. 301; Jakobson, 1913, Käfer Russland, pt. 10, p. 805.

Amphicerus (Schistoceros) bimaculatus Lesne, 1938, in Junk (pub.), Coleopt. Cat., pt. 161, p. 42.

The bibliography given for this species is not complete, as only the more important articles have been cited.

Male.-Elongate, cylindrical, uniformly black or brownish black, the antennae, palpi, and tarsi brownish yellow.

Head much narrower than pronotum, slightly flattened behind eyes, densely, finely granulose over entire surface, with fine, longitudinal, parallel carinae on occiput, densely clothed with long, erect, yellowish hairs on clypeus and front of head; clypeus nearly flat, coarsely, sparsely punctate, smooth along anterior margin; clypeal suture not distinct; labrum finely, densely punctate, first segment of antennal club subtriangular, produced on outer side at apex; eyes small, transverse.

Pronotum quadrate, rounded in front, widest near middle, strongly deflexed anteriorly; sides very broadly rounded, the apical angles rounded and unarmed; surface coarsely imbricate-punctate on basal half, coarsely, sparsely tuberculate anteriorly, the tubercles broad, semierect, and rather acutely rounded at apices, densely, irregularly clothed with semierect, yellowish hairs between tubercles on apical half, with a large patch of long, recumbent, white pubescence, concealing the surface, at each side on basal half. Scutellum densely clothed with moderately long, erect, yellowish hairs.

Elytra at base subequal in width to pronotum at middle, sinuate at base, each elytron with a short, arcuate spine at top of apical declivity, and a small tooth at apical angle of sutural margin; sutural margins slightly elevated on apical declivity; sides vaguely expanded posteriorly, conjointly broadly rounded at apices, margins not elevated but crenulate toward apices; surface coarsely, sparsely, very irregularly punctate, more or less rugose, irregularly clothed with rather dense patches of moderately long, recumbent, yellowish hairs, the reliefs smooth and shining.

Body beneath finely, densely punctate, densely clothed with long, recumbent, white hairs.

Female.-Differs from the male in having the apical declivity of the elytra coarsely, densely, irregularly granulose, each elytron with a round callosity at the top of the apical declivity, and in not having a small tooth at the apices of the elytra.

Length 5-11 mm., width 2-3.2 mm. 
Type locality.-Provence, France; type probably in the Paris IIuseum.

Distribution.-This species is widely distributed throughout the Mediterranean Region of Europe, Africa, and Asia Minor. One specimen was intercepted at New York, June 1, 1938, in dried roots from Turkey.

Hosts.-This species lives in grape, Lycium, and Tamarix, and Rey (1877) recorded the larvae living in the trunks of Tamarix and reducing them to dust.

\section{AMphicert's (SCHistoceros) teres Horn}

Amphicerus teres Horn, 1878, Amer. Phil. Soc. Proc. 17: 547, 548; Casey, 1898, N. Y. Ent. Soc. Jour. $6: 70$.

Schistoceros teres Lesne, 1S99, Soc. Ent. de France Ann. (1598) 67: 505-509, 522-523, figs. 132-133.

Amphicerus (Schistoceros) teres Lesne, 1938, in Junk (pub.), Coleopt. Cat., pt. 161, p. 42.

Male.-Elongate, cylindrical, shorter than hamatus, uniformly dark reddish brown to brownish black, the antennae and palpi brownish or reddish yellow.

Head much narrower than pronotum, broadly, transversely flattened behind eyes, with an arcuate carina between flattened area and occiput, finely, densely granulose, with a number of larger granules and densely clothed with long, erect, yellowish hairs on clypeus and conrex area behind clypeus, raguely punctate and granulose on transverse flattened area, with long, longitudinal, parallel carinae on occiput; clypeal suture not distinct, sometimes raguely indicated at middle; labrum finely, densely punctate; first segment of antennal club subtriangular, truncate at apex; eyes small and oral.

Pronotum quadrate, vaguely emarginate in front, widest just behind middle, strongly deflexed anteriorly; sides very broadly rounded, more strongly converging anteriorly, produced into a small, broad tubercle at apical angles; surface with numerous short, longitudinal costae at middle of basal half, densely tuberculate on apical half, some of the tubercles broad, semierect, and rasplike, with four or five larger tubercles on each side along lateral margin, sparsely clothed with long, erect, inconspicuous hairs on apical half and toward sides. Scutellum nearly glabrous.

Elytra at base slightly narrower than pronotum near middle, truncate at base, without tubercles or callosities on apical declivity; sutural margins thickened and strongly elevated at middle of apical declivity ; sides slightly expanded posteriorly, truncate or subtruncate at apices, margins not elevated; surface coarsely, deeply, densely, irregularly punctate, sparsely clothed with rather long, erect, yellowish hairs.

Abdomen beneath finely, densely, shallowly punctate, rather densely clothed with long, recumbent, vellowish hairs; metasternum and mesosternum sparsely, finely, shallowly punctate, sparsely clothed with short, recumbent, yellowish hairs.

Female.-Differs from the male in having the pronotum rounded or subtruncate and unarmed at apical angles, the sides of the elytra palallel, and the eyes large and round.

Length 6-8 mm.. width 2-2.5 mm.

Type Tocality.-Fort Yuma, Calif.: trpe in the Horn Collection in the Academy of Natural Sciences of Philadelphia. 


\section{Distribution.-From material examined:}

ArIzona : Douglas, June 19, 1945 (W. W. Jones). Hot Springs, June 27 (Barber and Schwarz). San Simon, July 7 (Hubbard and Schwarz). Sabino Canyon, June 20, 1918 (G. Hofer).

California: Indio (A. C. Davis).

Texas : Presidio, May 22, 1945.

Hosts.-This species has been reared from Hymenoclea monogyra collected in Sabino Canyon, Ariz., by G. Hofer.

\section{Amphicerus (Schistoceros) SIMPlex (Horn)}

Sinoxylon simplex Horn, 1885, Amer. Ent. Soc. Trans. 12 : 155.

Micrapate simplex Casey, 1898, N. Y. Ent. Soc. Jour. $6: 72,73$.

Schistoceros simplex Lesne, 1S99, Soc. Ent. de France Ann. (1S98) 67 : 509, 523524, figs. 134-135.

Amphicerus (Schistoceros) simplex Lesne, 193S, in Junk (pub.), Coleopt. Cat., pt. 161 , p. 42 .

Amphicerus brevicollis Casey, 189S, N. Y. Ent. Soc. Jour. 6: 69-70 ; Lesne, 1937, Soc. Ent. de France Bul. 42: 238.

Amphicerus grandicollis Casey, 1898, N. Y. Ent. Soc. Jour. 6: 69, 70; Lesne, 1938, in Junk (pub.), Coleopt. Cat., pt. 161, p. 41.

(New synonymy.)

Male.-Elongate, cylindrical, uniformly reddish brown to brownish black, the palpi and antennae yellowish brown.

Head much narrower than pronotum, transversely flattened behind eyes, coarsely, sparsely granulose and densely clothed with short, erect, yellowish hairs behind clypeus, finely granulose and nearly smooth on transverse flattened area, with long, longitudinal parallel carinae on occiput; clypeus flat, sparsely, coarsely granulose, densely clothed with short, erect, yellowish hairs; clypeal suture distinct; labrum finely, densely punctate; first segment of antennal club subtriangular.

Pronotum quadrate, arcuately emarginate in front, widest behind middle, strongly deflexed anteriorly; sides broadly rounded, more strongly converging anteriorly, produced into a short, unciform horn at apical angles; surface finely costulate-punctate on basal half, densely tuberculate on apical half, the tubercles broad, semierect, rasplike, and rather acute at apices, with six to eight larger tubercles on each side along lateral margin, and with a few short, erect hairs on apical half. Scutellum nearly glabrous.

Elytra at base slightly narrower than pronotum at middle, truncate at base, without tubercles or callosities on apical declivity; sutural margins strongly elevated on apical declivity; sides slightly expanded posteriorly, conjointly broadly rounded at apices, margins not elevated; surface coarsely, densely, irregularly punctate, more or less rugose, with a few very short, erect hairs.

Body beneath finely, densely punctate, sparsely clothed with short, recumbent hairs on mesosternum and metasternum, densely clothed with long, recumbent, yellowish hairs on abdomen.

F emale.-Differs from the male in having the elytra at base subequal in width to the pronotum near the middle, the pronotum truncate or rounded in front, without horns at the apical angles, and the sides of the elytra parallel.

Length 6.5-9 mm., width 2-3 mm.

Type locality.-Of simplex, Southwestern Texas; type in the Horn Collection in the Academy of Natural Sciences of Philadelphia. Of brevicollis and grandicollis, El Paso, Tex.; types in the Casey Collection in the United States National Museum. 


\section{Distribution.-From material examined:}

Arizora : Hot Springs, June 21-27 (Barber and Schwarz). Oracle, Juls 11; Catalina Springs, Mas; and Tucson, June 22 (Hubbard and Schwarz). Cotton City, August 5, 1919 ; and Sabino Canjon, June 8, 1919 (G. Hofer). Santa Catalina Mountains (M. Chrisman). Cat Pass, Tucson Mountains, August 29, 1913 (T. D. Pierce).

NEW Mexico: Mesilla Park, June \& (H. F. Wickham). Demming, July 2, 1937 (C. E. Burt).

Texas: El Paso (types of brevicollis and grandicollis). Eagle Pass, April 24, 1914.

Hosts.-This species has been reared from little-leaf horsebean (Parkinsonia microphylla), palo-verde (Cercidium torreyanum), and mistletoe (Phoradendron flavescens).

Casey (1898) described brevicollis from four specimens and grandicoltis from a single male, all from the same locality. Lesne (1937) placed brevicollis as a synonym of simplex Horn in his subgenus Schistoceros. After studying the type of grandicollis the writer is unable to separate it from simplex.

\section{Genus LICHENOPHANES Lesne}

Lichenophanes Lesne, 1899, Soc. Ent. de France Ann. (1S9S) 67: 443, 35i-502; Schilsky, 1899, in Küster and Kraatz, Käfer Europas, 36 : p. UU ; Lesne, 1901, Abeille 30: 86, 90-92, pl. 1, fig. 27; Everts, 1901, Coleopt. Neerlandica, v. 2, pp. 210, 212 ; Csiki, 1903, Ror. Lapok. 10 : 18; Reitter, 1911, Fauna Germanica, 3 : 301, 303; Jakobson, 1913, Käfer Russland, pt. 10, pp. 803, 805; Lesne, 1924, Bostrychides de l'Afrique Tropicale Française, pp. 113, 115-131, figs. 63-70; 193S, in Junk (pub.), Coleopt, Cat., pt. 161, pp. 33-36.

Bostrichus LeConte, 1861, Smithsn. Inst. Misc. Collect. 3 (1) : 208; Horn, 1878, Amer. Phil Soc. Proc. 17: 545-546; LeConte and Horn, 1883, Smithsn. Inst. Misc. Collect. 507 : 228; Caser, 189S, N. Y. Ent. Soc. Jour. 6: 66, 71-72.

Head slightly convex, deeply inserted in prothorax, not visible from above; clypeus strongly transverse, flat or slightly convex, broadly rounded at anterior angles (except in truncaticollis), subtruncate or raguely emarginate in front; clypeal suture distinct or obsolete; labrum short, transverse, truncate or vaguely emarginate and densely ciliate, with long, blackish or vellow hairs in front; margins of buccal carities not dentate below ejes; mandibles more or less attenuate toward apices; eyes round or oval, globose, strongly projecting. Antenna 9 - or 10-segmented: first and second segments robust, oblong, second shorter than first; third to sixth or serenth narrow, subequal in length to one another, the third and fourth slightly elongate, fifth round. sixth or serenth slightly transrerse: last three segments forming a broad, loose, compressed club, each with two small round sensory depressions on each surface, first and second segments of club subglobose, oral, or slightly transverse, apical segment oblong, broadly rounded at apex, longer than the first or second. Pronotum strongly convex, truncate at base, emarginate in front, dentate anteriorly; sides not margined. Scutellum small, quadrate. Elytra strongly conrex, with or without longitudinal costae, sometimes lobed or tuberculate at base, arcuately declivons posteriorly, with or without tubercles on apical declivity. Legs short, subequal in length: tibiae slightly expanded toward̆ apices, anterior pair dentate on exterior margins, each with a large, arcuate spine at apex: posterior tarsi as long as, or longer than tibiae, apical segment of each shorter than preceding four segments united. Anterior coxae contiguous. Middle coxae narrowly 
separated. Posterior coxal cavities completely margined on first visible abdominal sternite. Intercoxal process of abdomen tubular or narrowly triangular. Body elongate, cylindrical.

Genotype.-Apate varia Illiger. (Present designation.)

Lesne (1899) erected this genus for 24 species without designating a genotype. The species of this genus are distributed throughout all parts of Africa, southeastern Asia, and the greater part of America, and one species has been described from Europe and another one from Japan. In some species the secondary sexual characters are quite distinct in the two sexes, whereas in other species these characters are not noticeable.

\section{KEY TO THE SPECIES OF LICHENOPHANES}

1. Pronotum in front with two unciform processes .

Pronotum in front without unciform processes, simply arcuately emargi-

2. Elytra with tufts of erect, blackish hairs - fasciculatus (Fall), p. 76 .

3. Dlytra without tufts of erect, blackish hairs middle; pronotum with two round depressions in front of scutellum; declivity of elytron with a costiform tubercle _- spectabilis Lesne, p. 77 .

Piceous; labrum with a fringe of yellowish hairs not interrupted at middle; pronotum without depressions in front of scutellum; declivity of elytron without a costiform tubercle

4. Antenna 9-segmented; elytra conjointly rounded at apices; pubescence on elytra slender, hairlike_............. arizonicus, new species, p. 77.

Antenna 10-segmented; elytra conjointly angularly emarginate at apices; pubescence on elytra not slender, more or less scalelike. . . . . .

5. Hairs on elytra not more than twice as long as wide; each elytron with inner costa strongly elevated and extending from base to apical declivity, the outer costa usually only indicated posteriorly

bicornis (Weber), p. 78.

Hairs on elytra at least three times as long as wide; each elytron with the inner costa feebly indicated and interrupted, sometimes only indicated on basal fourth, the outer costa not present_-_ armiger (LeConte), p. 79.

6. Elytra very sparsely, indistinctly pubescent, the pubescence not forming spots, each elytron sometimes with two vague costae

californicus (Horn), p. 80.

Elytra distinctly pubescent, the pubescence forming irregular spots, without costae

7. Antenna 10-segmented; labrum glabrous; clypeus with anterior angles rectangular........ truncaticollis (LeConte), p. 81.

Antenna 9-segmented; labrum pubescent; clypeus with anterior angles rounded . . . . . . . . . . . . . . . . . . . . mutchleri Belkin, p.

\section{Lichenophanes fasciculatus (Fall)}

Bostrichus fasciculatus Fall, 1909, Canad. Ent. 41: 162; Lesne, 1938, in Junk (pub.), Coleopt. Cat., pt. 161, p. 34.

Since the writer has not examined the type of fasciculatus and the species has been placed in the key solely upon the characters given in the original description, it seems advisable to include the following copy of the original description:

Bostrichus fasciculatus, n. sp.-Blackish-brown, moderately shining. Head closely punctate, front feebly margined at sides. Prothorax as wide as long, front margin sinuate, with two slender unciform processes; hind angles prominent, dentiform; entire upper surface strongly though not very densely tuberculate, and clothed thinly with moderately long, recumbent, subinterlacing yellowish-brown hairs, with numerous erect pointed tufts of blackish hairs. Elytra coarsely, deeply, subcribrately punctate, without costae; vestiture similar to 
that of the prothorax, the interspersed pointed tufts of blackish hairs longer and very conspicuous.

Length, $7 \mathrm{~mm}$.; width, $2.4 \mathrm{~mm}$. Santa Rosa, Lower California (Beyer). A most singular insect, totally different in its restiture from any species previously known to us.

The elytral fasciculae are approximately as follows: A subsutural series of three prominent tufts, exterior to which are three or four others less regularly placed; a sutural series of much smaller tufts, and a number of similar ones toward the side margin.

\section{Lichenophanes SPECTABILIS (Lesne)}

Bostrychus spectabilis Lesne, 1895, Soc. Ent. de France Ann. 64: 173; 1899, Ann. (1898) 67: 464, 494-496, fig. 98; 1938, in Junk (pub.), Coleopt. Cat., pt. 161, p. 35 .

Specimens of this species have not been seen by the writer and the species has been placed in the key from the characters given in the original description. It seems advisable therefore to include the following copy of the original description:

Bostrychus spectabilis, n. sp.-Long, 151/2 mill.-Allongé, graduellement élongi en arrière. Noir bluatre mat, plombé. Assez voisin de B. bicornis Web. Suture fronto-clypéale droite. Bord antérieur de l'épistome frangé de chaque côté de poils noirs. Échancrure, antérieur du prothorax large, rectangulaire. Disque du pronotum arec deux petites fossettes rapprochées, arrondies, peu enfoncées. Ecusson saillant, inégale. Tubercules juxta-scutellaire très saillants, dentiformes. Elytres flats, pontués de gros points allongès et ornés dosalement d'un réticulum irrégulier et discontinu de côtes saillantes à sommet lisse et brillant. Ces côtes présentent des poils très courts, peu abondants, d'un roux ardent. Déclivité élytrale très fortement ponctuée, munie de chaque côté supérieurement d'un tubercule costiforme; rebord inférieur brièvement incurvé en dessus latéralement. Suture peu saillante sur la déclivité. Pubescence des pattes noire-California (coll. R. Oberthür).

LICHENOPHANES ARIZONICUS, new species

Elongate, cylindrical, uniformly reddish brown; the palpi, antennae, and tarsi sometimes slightly paler; dorsal surface of body sparsely, irregularly clothed with short, recumbent or semierect, yellowish hairs.

Head much narrower than pronotum, finely, densely tuberculose, the tubercles distinctly separated on vertex; clypeus slightly convex; clypeal suture distinct; labrum densely ciliate with long, yellow hairs in front. Antenna 9-segmented; third segment elongate, twice as long as fourth, fourth round, fifth and sixth transverse.

Pronotum quadrate, strongly convex, widest near middle, strongly deflexed on apical half, with two unciform processes in front, without depressions or distinct gibbosities in front of scutellum; sides broadly rounded, more strongly converging anteriorly; posterior angles slightly rectangular; surface with a narrow, longitudinal, median, smooth space, densely, coarsely tuberculose, the tubercles small, round, and polished on basal half, larger, broader, and rasplike on apical half.

Elytra at base subequal in width to pronotum at middle, truncate at base, without longitudinal costae; sides parallel, conjointly broadly rounded at apices; surface coarsely, deeply, densely punctate, coarsely rugose between punctures.

Abdomen beneath very finely, densely granulose, sparsely clothed with very short, recumbent, yellowish hairs. 
Length 5-7.5 mm., width $1.5-2.5 \mathrm{~mm}$.

Type locality.-Santa Rita Mountains, Ariz.

Type and paratypes.-In the United States National Museum, No. 58313.

Described from five specimens (one type). The type and two paratypes were collected at the type locality, June 19, by E. A. Schwarz; and two paratypes from the Brooklyn Museum Collection were taken in the Huachuca Mountains, Ariz., probably by Charles Schaeffer. These are probably all females.

This species resembles small specimens of bicornis WVeber, but it differs from that species in having the antenna with only nine segments, the pronotum convex in front of the scutellum, the elytra truncate at base and without longitundinal costae, and the dorsal surface of the body irregularly clothed with short, yellowish hairs.

\section{LICHENOPHANES BICORNIS (Weber)}

Apate bicornis Weber, 1801, Observationes Entomologicae, pp. 91-92; Melsheimer, 1806, Catalogue of the Insects of Pennsylvania, p. 132; Say, 1824, Acad. Nat. Sci. Phila. Jour. 3 : 319-320.

Bostrichus bicornis Horn, 1878, Amer. Phil. Soc. Proc. 17: 545-546; McBride, 1880, Canad, Ent. 12: 107 ; Packard, 1890, U. S. Ent. Commr. Rpt. 5 : 92, fig. 34; Casey, 1898, N. Y. Ent. Soc. Jour. 6: 71-72; Blatchley, 1910, Coleoptera of Indiana, pp. 888, 899 ; Leonard, 1928, N. Y. (Cornell) Agr. Expt. Sta. Mem. 101: 415 ; Brimley, 1938, Insects of North Carolina, p. 198.

Bostrychus bicornis Hopkins, 1893, W. Va. Agr. Expt. Sta. Bul. 32 : 189 ; Lintner, 1896, N. Y. State Mus. Rpt. 49 (1895), p. 268.

Lichenophanes bicornis Lesne, 1899, Soc. Ent. de France Ann. (1898), 67: 462, 481-483, figs. 58, 83, 84 ; 1938, in Junk (pub.), Coleopt. Cat., pt. 161, p. 33 ; Anderson, 1939, Wash. Acad. Sci. Jour. 29 (9) : 390, figs. 25, 30, 32 (larrae); Belkin, 1940, Ent. News 51: 193.

Mate.-Elongate, cylindrical, dark reddish brown, palpi, antennae, and tarsi sometimes slightly paler; dorsal surface of body irregularly clothed with small, oblong, yellowish-white scales, which are not more than twice as long as wide.

Head much narrower than pronotum, more or less rugose, sparsely, coarsely tuberculose; clypeus flat; clypeal suture distinct; labrum densely ciliate with long yellowish hairs in front. Antenna 10-segmented; third segment slightly elongate, fourth to seventh round or slightly transverse.

Pronotum quadrate, widest near middle, strongly deflexed on apical half, with two unciform processes in front; without a depression but with two small gibbosities in front of scutellum; sides broadly rounded, more strongly converging anteriorly, posterior angles rectangular; surface with a narrow, longitudinal, median groove on basal half, densely, irregularly granulose, the tubercles small and round on basal half, becoming larger, broader, and rasplike on apical half.

Elytra at base subequal in width to pronotum at middle, tuberculate at base, each elytron with two crenulate, longitudinal costae, the inner costa strongly elevated and extending from base to apical declivity, the outer costa usually only indicated posteriorly; sides parallel, conjointly angularly emarginate at apices, with a small, acute spine on each side of emargination; surface coarsely, deeply, irregularly punctate, more or less rugose, with numerous small, round, polished tubercles, the scales denser in places giving the surface a variegated appearance. 
Body beneath very finely, densely, indistinctly granulose, sparsely clothed with small, recumbent, scalelike, yellowish-white hairs.

Female.-Differs from the male in not having an acute spine at the apex of each elytron.

Length 7-12 mm., width 2-4 mm.

Type locality.- "America"; present location of type unknown to writer.

Distribution.-This species is common throughout the eastern part of the United States and Canada. Specimens have been examined from the District of Columbia, Florida, Georgia, Illinois, Iowa, Kansas. Louisiana, Maryland, Michigan, Missouri, Nebraska, New York, New Jersey, Ohio, Oklahoma, Pennsylvania, Tennessee, Texas, Virginia, and West Virginia.

Hosts.-The species is recorded as living in sycamore, hackberry, oak, pecan, hickory, apple, beech, and elm. The larvae are usually found under the dead bark and in the dead wood of its hosts, but specimens received from Georgia were reported as boring in the dead cambium of a live sycamore tree.

This species was described by Weber (1801) from America without giving any definite locality, and Say (1824) redescribed the same species as Apate bicornis, giving above the mouth of the Ohio River as the type locality, and citing this name from the Melsheimer Catalogue.

\section{Lichenophanes aRmiger (LeConte)}

Bostrichus armiger LeConte, 1866, Smithsn. Inst. Misc. Collect. 167: 100-101; Horn, 1878, Amer. Phil. Soc. Proc. 17: 545, 546; Casey, 1898, N. Y. Ent. Soc. Jour. 6 : 71-72; Blatchley, 1910, Coleoptera of Indiana, pp. 888, 889.

Lichenophanes armiger Lesne, 1899, Soc. Ent. de France Ann. (1898) 67: 462, 480-481, fig. 82 ; 1938, in Junk (pub.), Coleopt. Cat., pt. 161, p. 33; Brimley, 1938, Insects of North Carolina, p. 198; Anderson, 1939, Wash. Acad. Sci. Jour. 29 (9) : 390, figs. 27, 28, 31, 33 (larvae).

Male.-Elongate, cylindrical, dark reddish brown, palpi, antennae, and tarsi slightly paler; dorsal surface of body irregularly clothed with yellowish-white, scalelike hairs, which are at least three times as long as wide.

Head much narrower than pronotum, more or less rugose, sparsely, finely tuberculose; clypeus slightly convex; clypeal suture distinct; labrum densely ciliate with long, yellow hairs in front. Antenna 10-segmented; third segment slightly elongate, fourth to seventh round or slightly transverse.

Pronotum quadrate, strongly convex, widest at middle, strongly deflexed on apical half, with two unciform processes in front, without depressions or distinct gibbosities in front of scutellum; sides broadly rounded, more strongly converging anteriorly; posterior angles rectangular; surface with a narrow, longitudinal, median groove on basal half, rather densely, coarsely tuberculose, the tubercles smooth and round basally, becoming slightly broader and more rasplike on anterior half.

Elytra at base slightly wider than pronotum at middle, tuberculate at base, each elytron with a single crenulate costa, which is vaguely indicated, frequently interrupted, sometimes only indicated on basal fourth; sides parallel, conjointly angularly emarginate at apices, with a small acute spine on each side of emargination; surface coarsely, 
deeply, confluently punctate, more or less rugose, with numerous round, polished tubercles, and with small, irregularly distributed, densely pubescent spots.

Body beneath very finely, densely, indistinctly granulose, sparsely clothed with short, recumbent, yellowish-white hairs.

Female.-Differs from the male in not having an acute spine at the apex of each elytron.

Length 5.5-11 mm., width $1.75-3.6 \mathrm{~mm}$.

Type locality.-Middle and Southern States; type in the LeConte Collection in the Museum of Comparative Zoology, at Cambridge, Mass.

Distribution.-This species is distributed throughout the eastern part of the United States and Canada. Specimens have been examined from Colorado, District of Columbia, Georgia, Iowa, Kansas, Louisiana, Maryland, Michigan, Missouri, New Jersey, New York, North Carolina, Oklahoma, Pennsylvania, Rhcde Island, Texas, Virginia, and West Virginia.

Hosts.-Fiske reports this species on Quercus sp. in North Carolina, and Champlain reared specimens of this species from Quercus gambelii and Acer sp. in Colorado.

\section{Lichenophanes CALIFORNicus (Horn)}

Bostrichus californicus Horn, 1878, Amer. Phil. Soc. Proc. 17 : 545, 546; Casey, 1898, N. Y. Ent. Soc. Jour. 6: $71-72$.

Lichenophanes californicus Lesne, 1899, Soc. Ent. de France Ann. (1898) 67 : 460, 473; 1938, in Junk (pub.), Coleopt. Cat., pt. 161, p. 34 ; Belkin, 1940, Ent. News 51: 193.

Elongate, cylindrical, uniformly black, the palpi, antennae, and tarsi slightly reddish; dorsal surface of body sparsely clothed with short, recumbent, yellowish-white hairs, which do not form pubescent spots.

Head much narrower than pronotum, densely, finely granulose, with numerous small, round tubercles intermixed; clypeus flat; clypeal suture distinct; labrum densely ciliate with long yellowish-brown hairs in front. Antenna 10-segmented; third segment slightly elongate, fourth to seventh round or slightly transverse.

Pronotum quadrate, strongly convex, widest near middle, strongly deflexed on apical half, without unciform processes, but deeply emarginate and tuberculate in front, without depressions or gibbosities in front of scutellum; sides broadly rounded, more strongly converging anteriorly; posterior angles rectangular; surface with a narrow, more or less distinct, longitudinal, median, smooth space on basal half, rather densely, coarsely tuberculose, the tubercles smooth and round basally, becoming larger, broader, and rasplike on anterior half.

Elytra at base subequal in width to pronotum at middle, truncate at base, sometimes each elytron with two vague longitudinal costae; sides parallel, broadly conjointly rounded at apices; surface coarsely, deeply, densely punctate, densely rugose between punctures.

Body beneath very finely, densely granulose or rugose, very sparsely clothed with short, recumbent, yellowish-white hairs.

Length $7-10 \mathrm{~mm}$. , width $2-3.5 \mathrm{~mm}$.

Type locality.-San Joaquin Valley, Calif.; type in the Horn Collection in the Academy of Natural Sciences of Philadelphia. 
Distribution.-From material examined:

California: Los Gatos (Hubbard and Schwarz). Fresno, May 3 (E. A. Sohwarz). Cordelia, Solano County, June 9, 1933 (E. C. Zimmerman).

Host.-Nothing has been recorded on the habits of this species, but Zimmerman collected the adults on Quercus agrifolia.

Horn described this species from a single female and the species was unknown to Lesne (1899) when he published his revision of the genus.

\section{Lichenophanes truncaticollis (LeConte)}

Bostrichus truncaticollis LeConte, 1866, Smithsn. Inst. Misc. Collect. 167: 101; Horn, 1878, Amer. Phil. Soc. Proc. 17: 545, 546; Casey, 1898, N. Y. Ent. Soc. Jour. 6: 71-72 ; Blatchley, 1910, Coleoptera of Indiana, pp. 888, 889.

Lichenophanes truncaticollis Lesne, 1899, Soc. Ent. de France Ann. (1898) 67 : 459, 467-468, figs. 64-65; Leonard, 1928, N. Y. (Cornell) Agr. Expt. Sta., Mem. 101: 415 ; Lesne, 1938, in Junk (pub.), Coleopt. Cat., pt. 161, p. 35.

Male.-Elongate, cylindrical, uniformly dark reddish brown, the palpi, antennae, and tarsi brownish yellow; dorsal surface of body unevenly clothed with moderately long, recumbent, whitish hairs, which form more or less distinct pubescent spots.

Head much narrower than pronotum, densely, finely granulose, finely tuberculose, the tubercles narrowly separated; clypeus flat, indistinctly punctate, anterior angles rectangular; clypeal suture distinct; labrum indistinctly punctate, glabrous, densely ciliate with long, yellowishwhite hairs in front. Antenna 10-segmented; third to seventh segments round or slightly transverse.

Pronotum quadrate, strongly convex, widest near middle, strongly deflexed on apical half, truncate or broadly emarginate in front, without unciform processes in front or depressions in front of scutellum; sides broadly rounded; posterior angles rectangular, surface with a narrow, longitudinal, median carina or smooth space on basal half, finely, rather densely irregularly tuberculose, the tubercles becoming rasplike toward apical angles.

Elytra at base slightly wider than pronotum at middle, truncate at base, without longitudinal costae; sides parallel, conjointly broadly, arcuately emarginate at apices, with a long acute spine on each side of emargination; surface coarsely, deeply, confluently punctate, the intervals slightly rugose.

Body beneath finely, densely punctate, sparsely clothed with short, recumbent, inconspicuous hairs.

Female.-Differs from the male in having the apex of each elytron obtusely angulate and without a long, acute spine, and the last abdominal sternite most densely clothed with long, yellow hairs.

Length 6-9 mm.; width $2-2.6 \mathrm{~mm}$.

Type locality.-Alabama and Kentucky; types in the LeConte Collection in the Museum of Comparative Zoology, Cambridge, Mass.

Distribution.-This species is distributed throughout southern Canada and the eastern United States.

Material has been examined from the following localities:

Canada: Ontario (Wickham Collection).

Georgia : Acworth, June 13, 1937 (P. W. Fattig).

IlLiNoIS: Heyworth (A. B. Wolcott).

KENTUCKY: (Riley Collection).

Michigan : Detroit (Hubbard and Schwarz).

$842409-50-6$ 
Missouri : St. Louis, May 20 (H. Soltau Collection).

NEW York: Syracuse (M. W. Blackman).

TEXas: (Belfrage).

VIRGINia: Nelson County, June 23, 1919 (Wirt Robinson).

Hosts.-Blackman collected adults on Hicoria glabra (Miller) Sweet at Syracuse, N. Y.

LeConte (1866) described this species from two specimens, male and female, one from Alabama received from S. S. Haldeman, and one from Kentucky from J. P. Wild, without designating either place as the type locality.

\section{LiCHENOPHANES MUTCHLERI Belkin}

Bostrichus angustatus Casey, 1898, N. Y. Ent. Soc. Jour. 6 : 71-72 ; Leonard, 1928, N. Y. (Cornell) Agr. Expt. Sta., Mem. 101:415.

Lichenophanes angustatus Lesne, 1938, in Junk (pub.), Coleopt. Cat., pt. 161, p. 33. Lichenophanes mutchleri Belkin, 1940, Ent. News 51: 192 (new name for angustatus Casey (1898) not Steinheil (1872)).

Elongate, cylindrical, uniformly dark reddish brown, the palpi, antennae, and tarsi brownish yellow; dorsal surface of body rather unevenly clothed with moderately long, recumbent, yellowish hairs, which form more or less distinct pubescent spots.

Head much narrower than pronotum, densely, finely granulose, with numerous small, round tubercles intermixed; clypeus pubescent, flat; clypeal suture distinct; labrum densely ciliate with long, yellowish hairs in front. Antenna 9-segmented; third segment slightly elongate, fourth to sixth transversely oval.

Pronotum quadrate, strongly convex, widest near middle, strongly deflexed on apical half, truncate in front, without unciform processes in front or depressions in front of scutellum, but sometimes slightly gibbose on each side at middle of disk; sides broadly rounded, more strongly converging anteriorly; posterior angles rectangular; surface with a narrow, longitudinal, median carina on basal half, coarsely, rather densely, irregularly tuberculose.

Elytra at base slightly wider than pronotum at middle, truncate at base, without longitudinal costae; sides parallel, broadly conjointly rounded at apices; surface coarsely, deeply, densely punctate, finely, densely granulose and vaguely tuberculose between punctures.

Body beneath finely densely granulose or rugose, sparsely clothed with short, recumbent, yellowish hairs.

Length 5-7 mm., width 1.5-2 mm.

Type locality.-Woodbury, N. J.; type in the Casey Collection in the United States National Museum.

Distribution.-From material examined:

Canada: Toronto, June 15 (R. J. Crow).

Maryland: Great Falls, July 2, 1919 (L. L. Buchanan).

Mrchigan : Detroit, June (Hubbard and Schwarz).

New Jersey: Woodbury. Type.

New York: Albany (H. Soltau Collection).

West Virginia : Harpers Ferry (Hubbard and Schwarz).

Hosts.-Nothing has been recorded on the habits of this species.

Casey (1898) described his Bostrichus angustus from a single example. However, Steinheil (1872) had previously described a species from South America under the same name, and Belkin (1940) proposed mutchleri for angustus Casey (not angustus Steinheil). 
In the original description, Casey states that the insect is black, but on examining the type, it was found to be dark reddish brown.

\section{Genus HETEROBOSTRYCHUS Lesne}

Heterobostrychus Lesne, 1899, Soc. Ent. de France Ann. (189S) 67: 443, 5̄54-565: 1901, Abeille 30: 86, 93-94; Jakobson, 1913, Käfer Russland, pt. 10, pp. 803, \$05 ; Lesne, 1924, Bostrychides de l'Afrique Tropicale Française, pp. 114, 133137 ; 1938, in Junk (pub.), Coleopt. Cat., pt. 161, pp. 37-38.

Head convex on vertex, transversely flattened behind eyes, deeply inserted in prothorax, not visible from above; clypeus long, strongly transverse, convex or flattened, truncate or emarginate in front, anterior angles obtuse or rectangular; clypeal suture obsolete or distinct at middle; labrum short, strongly transverse, subtruncate and densely ciliate with long, yellow or brownish hairs in front; margins of buccal cavities not dentate below eyes; mandibles more or less attenuate toward apices; eyes round or oval, sometimes globose, strongly projecting. Antenna short, 10-segmented; first and second segments robust, first oblong, second oval, shorter than first; third to seventh segments short, narrow, round or transverse; subequal in length to one another; last three segments forming a broad, loose, compressed club, each with two small, round, sensory depressions on each surface, eighth and ninth segments subtriangular, subequal in length to each other, tenth equal to, or slightly longer than ninth, round or oblong, sometimes narrower than ninth. Pronotum strongly convex, truncate at base, emarginate in front, dentate anteriorly, transversely depressed behind anterior margin; sides not margined; posterior angles round, obtuse or rectangular, sometimes lobed and projecting. Scutellum small, quadrate. Elytra strongly convex, without distinct longitudinal costae, sinuate or truncate at base, with or without tubercles on apical declivity. Legs short, subequal in length; tibiae slightly expanded toward apices, anterior pair dentate on exterior margins, each with a large arcuate spine at apex; posterior tarsi as long as tibiae, apical segment of each shorter than preceding four segments united. Anterior coxae contiguous. Middle coxae narrowly separated. Posterior coxal cavities completely margined on first visible abdominal sternite. Intercoxal process of abdomen tubular or narrowly triangular. Body elongate, cylindrical.

Genotype.-Bostrichus aequalis Waterhouse. (Present designation.)

Lesne (1899) erected this genus for five species without designating a genotype.

The species of this genus are not very numerous, inhabiting the warm parts of the Old World, but a few of these species have been carried in commerce to other parts of the world.

\section{KEY TO THE SPECIES OF HETEROBOSTRYCHUS}

Dorsal surface of body sparsely clothed with very short, recumbent, yellowish hairs ; pronotum with median part on basal half granulose

brunneus (Murray), p. $\$ 3$.

Dorsal surface of body glabrous; pronotum with median part on basal half imbricate-punctate__._. acqualis (Waterhouse), p. SJ.

Heterobostrychus brunneus (Murray)

Bostrichus brunneus Murray, 1867, Ann. and Mag. Nat. Hist. (ser. 3) 20: 92-93. Bostrychus brunneus Quedenfeldt, 1886, Berlin. Ent. Ztschr. 30: 326-327 ; Lesne, 1896, Soc. Ent. de France Bul., p. 334. 
Heterobostrychus brunneus Lesne, 1899, Soc. Ent. de France Ann. (1898) 67 : 557, 564-565, figs. 44, 169, 176, 177; Jakobson, 1913, Käfer Russland, pt. 10, p. 805; Lesne, 1924, Bostrychides de l'Afrique Tropicale Française, pp. 134-137, figs. 3, 4, 22, 73-75; 1935, Rev. Zool. et Bot. Africaine 27 (1): 9; 1938, in J'unk (pub.), Coleopt. Cat., pt. 161, pp. 37-38; Tooke and Scott, 1944, So. Africa Dept. Agr. and Forestry, Bul. 247 (Ent. Ser. 14) : 7, 9-11, figs. 9-11.

Bostrychus grayanus Wollaston, 1867, Coleoptera Hesperidum, pp. 109-110.

Bostrichus picipennis Fåhraeus, 1872, Öfvers. Vetensk. Akad. Fōrhandl. (1871), (1871), 28: 669.

Elongate, cylindrical, subopaque, uniformly dark reddish brown, the palpi, antennae, and tarsi sometimes paler; dorsal surface of body sparsely clothed with very short, recumbent, yellowish hairs.

Head much narirower than pronotum, densely, coarsely granulose in front, with short longitudinal, parallel carinae on occiput; clypeus nearly flat, densely, coarsely punctate, broadly, shallowly emarginate in front; clypeal suture obsolete; labrum densely ciliate in front with long, golden yellow hairs.

Pronotum quadrate, strongly convex, widest at posterior angles, strongly deflexed on apical half, armed at middle of anterior margin with two strong, arcuate, more or less hooked teeth, which are narrowly or broadly separated at middle; sides parallel at middle, strongly converging anteriorly; posterior angles rectangular, slightly projecting and forming rounded lobes; surface finely, densely granulose, the granules round and not flattened on basal half, with large, broad, rasplike teeth on apical half, the teeth much larger along lateral margins anteriorly.

Elytra at base subequal in width to pronotum at posterior angles, slightly sinuate at base, sometimes with obsolete longitudinal costae, without tubercles on apical declivity, but with a short costa on each elytron along lateral margin on upper half of elytral declivity; sides parallel, broadly conjointly rounded at apices; surface coarsely, deeply, uniformly, very densely punctate.

Body beneath finely, densely punctate, sparsely clothed with very short, recumbent, yellowish hairs; last visible abdominal sternite densely clothed with long, yellowish hairs at apex.

Length $4.5-11 \mathrm{~mm}$., width 1.2-3.5 mm.

Type locality.-Of brunneus, Old Calabar, Africa; type in the British Museum. Of grayanus, Santa Iago, Cape Verde Islands; type in the British Museum. Of picipennis, Caffraria, Africa; type either in the Stockholm or the Göteberg Museum.

Distribution.-This species is distributed throughout southern Africa south of the Sahara Desert, and in Madagascar, and the Cape Verde and Seychelles Islands. Specimens have been intercepted at New York in wooden boxes, and mahogany logs from the Belgian Congo, Southern Rhodesia, and the Gold Coast, Africa; at Cherokee, Iowa, in boxes from Africa; and at St. Paul, Minn., and Arlington. Mass., in wooden ornaments from southern Africa.

Hosts.-Lesne (1924) stated that the species usually lives in the wood of bamboo, is common in bamboos used in construction work, and is one of the principal enemies of felled wood in southern Africa, where it also attacks the supports of buildings. In French Guinea it lives in the tubers of potatoes (Batatus edulis Chois). Tooke and Scott (1944) recorded the species from teak (Baikiaea plurijuga) and kiaat (Pterocarpus angolensis) as well as many species of Euca- 
Typtus. This species is capable of causing considerable damage to timbers, logs, and poles, reducing the wood to powder to the depth of 2 or 3 inches, but attacks only the sapwood.

Wollaston (1867) described grayanus from a single example collected by Mr. Gray in the interior of Santa Iago, Cape Verde Islands, under the loose bark of a recently felled gigantic native Ficus tree. Fåhraeus (1872) described picipennis from Caffraria, Africa, but Lesne (1896) placed both these species as synonyms of brunneus Murray (1867).

The sexes of brunneus are very difficult to separate on secondary sexual characters. In the extreme forms the males have the two median teeth on the anterior margin of the pronotum strongly hooked and rather narrowly separated by a deep angular emargination, whereas in the females the teeth are smaller, straight, and widely separated from each other. There are all kinds of intermediates between these two forms; sometimes the emargination is arcuate, angulose, trapezoidal, or rectangular.

\section{Heterobostrychus AEQUALis (Waterhouse)}

Bostrichus aequalis Waterhouse, 1884, Zool. Soc. London, Proc., pp. 215-216, pl. 16, fig. 3 .

Bostrychus aequalis Lefroy, 1909, Indian Insect Life, p. 316, fig. 193.

Heterobostrychus aequalis Lesne, 1899, Soc. Ent. de France Ann. (1898) 67: 557, 560-562, figs. 29, 31, 173, 174; 1904, Mission Pavie Indo-Chine, Ent. Div., 3 : 106, pl. 9, figs. 3-4; Fauvel, 1904, Rev. d'Ent. 23 (6) : 157-158; Jakobson, 1913, Käfer Russland, pt. 10, p. 805; Stebbing, 1914, Indian Forest Insects, pp. 148-149, figs. 88, 95; Lesne, 1926, Treubia 7: 119; F'roggatt, 1927, Forest Insects and Timber Borers, pp. 98-99; Gardner, 1933, Indian Forest Rec., Ent. Ser. 18 (9) : 13, 15, pl. 4, figs. 45-46 (larvae) ; Beeson, 1935, Indian Forester 61 (4) : 250-255; Beeson and Bhatia, 1937, Indian Forest Rec. (New Ser., Ent.) 2 : 225, 229, 257-262, 309-320, figs. 6-8; pl. 1, figs. 1-3; Lesne, 1938, in Junk (pub.), Coleopt. Cat., pt. 161, p. 37.

Bostrychus uncipennis Lesne, 1895, Soc. Ent. de France Ann. 64: 173.

Male.-Elongate, cylindrical, moderately shining, uniformly reddish brown to brownish black, the palpi, antennae, and tarsi brownish yellow; dorsal surface of body glabrous.

Head much narrower than pronotum, coarsely, very densely granulose on front, with short, longitudinal, parallel carinae on occiput; clypeus convex, finely, irregularly punctate, truncate in front; clypeal suture obsolete; labrum densely ciliate in front with long, goldenyellow hairs.

Pronotum quadrate, strongly convex, widest at middle or posterior angles, strongly deflexed on apical half, arcuately emarginate in front; sides broadly rounded or parallel at middle, strongly converging anteriorly; posterior angles rectangular or lobed and more or less projecting. Surface finely, sparsely, irregularly punctate, with a few coarse punctures intermixed, and more or less imbricate on basal half, densely tuberculose on apical half, the tubercles short, broad, and rasplike, and with four or five broad, erect tubercles on each side along lateral margins anteriorly.

Elytra at base subequal in width to pronotum at posterior angles, sinuate at base, without longitudinal costae, each elytron with two tubercles on apical declivity, the outer one straight, elongate, moderately elevated, inner tubercle long, arcuate, and more or less hooked at apex; sutural margins elevated on apical declivity; sides parallel, separately rounded at apices; surface densely, deeply, coarsely punc- 
tate, the punctures arranged in more or less distinct rows on disk, but sometimes becoming obsolete on apical declivity towards apices.

Body beneath finely, densely punctate, sparsely clothed with very short, recumbent, yellowish hairs; last visible abdominal sternite densely clothed with long, yellow hairs at apex.

Female.-Differs from the male in not having large, arcuate tubercles on the apical declivity of the elytra.

Length 6-13 mm., width 2.2-3.5 mm.

Type locality.-Of aequalis, Timor Laut Islands; present location of type unknown to writer. Of uncipennis, many localities-IndoChina, Southern Hindostan, Madagascar, and the Andaman and Marianne Islands; types in the Paris and Brussells Museums.

Distribution.-This species is widely distributed throughout India, Ceylon, Indo-China, Federated Malay States, Java, Philippines, New Guinea, Madagascar, and many of the Malaysian Islands. It has been intercepted a great many times at New York, N. Y.; San Francisco, Calif.; Dallas, Tex.; Allentown and Philadelphia, Pa.; and New Orleans, La., in wooden packing cases and Philippine mahogany, from India, Java and the Philippines. So far as known, it has not become established in the United States.

Hosts.-Beeson and Bhatia (1937) record the following host plants: Adina cordifolia, Albizzia stipulata, Anisoptera glabra, Bambusa arundinacea, Bombax anceps, B. insigne, B. malabaricum, Boswellia serrata, Canarium euphyllum, Cassia fistula, Cedrela toona, Dalbergia sissoo, Dendrocalamus strictus, Dipterocarpus pilosus, D. turbinatus, Endospermum chinese, Garuga pinnata, Koompassia malaccensis, Kydia calycina, Lannea grandis, Leucaena glauca, Mangifera indica, Morus indica, Parashorea stellata, Parishia insignis, Poinciana elata, Pterocarpus indicus, Quercus sp., Shorea leprosula, S. robusta, Sterculia alata, S. campanulata, Tectona grandis, Terminalia belerica, $T$. bialata, T. myriocarpa, T. tomentosa, and Anogeissus acuminata.

In India this is the commonest of the larger bostrichid beetles found boring in packing cases, boxes, plywood, chests, sapwood in furniture, and in sal (Shorea robusta) rafters of the thatched bungalows, and is a regular pest in sawmills and factories of wood-using industries. The beetles will bore through 1 to 2 inches of wood and make holes in the lead lining of boxes. When logs are heavily attacked the wood is reduced to powder to a depth of 2 to 3 inches.

The emargination on the anterior margin of the pronotum is quite variable in shape, arcuate, angulate, trapezoidal, and sometimes not very distinct. The posterior angles of the pronotum are rectangular, sometimes prolonged into a rounded lobe. The tubercles on the apical declivity of the elytra in the male are variable in shape and length, sometimes the outer one is represented by a rounded knob and sometimes by a short costiform tubercle, and the inner tubercle is variable in length and sometimes more robust and more strongly hooked. Sometimes the female has two more or less distinct costiform tubercles on the apical declivity of each elytron. The punctures on the apical declivity of the elytra are variable in density, sometimes as dense in the males as in the females.

Lesne (1895) described uncipennis from both sexes from many different localities, in various European collections, without designating 
any specimen as the type, but he (1899) placed uncipennis Lesne as a synonym of aequalis WVaterhouse.

Froggatt (1927) stated that he has examined the type of Rhizopertha papuensis (in Australia Museum) described by MacLeay from Fly River, New Guinea, which Lesne suggested was the same as aequalis, and that it is not the same as aequalis.

\section{Genus MICRAPATE Casey}

Micrapate Casey, 1898, N. Y. Ent. Soc. Jour. 6: 66, 72-73; Lesne, 1901, Abeille 30 : 87, 95-96; 1906, ibid. 30: 269-281, figs. 1-12 ; Reitter, 1911, Fauna Germanica, F. 3, pp. 302, 303-304; Jakobson, 1913, Käfer Russland, pt. 10, pp. 803, 805; Ererts, 1922, Coleopt. Neerlandica, r. 3, p. 365; Lesne, 1924, Bostrychides de l'Afrique Tropicale Française, pp. 114, 145-148; Gardner, 1933, Indian Forest Rec., Ent. Ser. 18 (9) : 16; Lesne, 193S, in Junk (pub.), Coleopt. Cat., pt. 161, pp. 41-46; 1939, Rer. Franç. Ent. 6 : 91, 101-111.

Bostrychutus Lesne, 1899, Soc. Ent. de France Ann. (1898) 67: 444, 591-617; Schilsky, 1899, in Küster and Kraatz, Käfer Europas 36 : pp. UU ; Lesne, 1900, Soc. Ent. de France Bul., p. 46; Ererts, 1901, Coleopt. Neerlandica, v. 2, pp. 210, 212.

Head strongly convex, not transversely depressed behind eyes, deeply inserted in prothorax, not visible from above; clypeus flat, strongly transverse, broadly, arcuately emarginate in front, anterior angles acute or rectangular; clypeal suture distinct or obsolete; labrum short, strongly transverse, truncate and densely ciliate with long, yellow hairs in front; margins of buccal cavities not dentate below eyes; mandibles more or less attenuate toward apices; eyes small, transverse, oval, strongly projecting. Antenna short, 9- or 10-segmented; first and second segments robust, first oblong, second oral, shorter than first; third to sixth or serenth short, oral or transverse, narrower than second, subequal in length to one another; last three segments forming a broad, rather compact, compressed club, subequal in length to one another, each with two round sensory depressions on each surface, first and second segments of club transverse, truncate at apices, apical segment oval. Pronotum strongly convex, strongly declivous and dentate anteriorly, subtruncate in front, truncate at base, not transversely depressed behind anterior margin; sides not margined. Scutellum small, quadrate. Elytra strongly convex, without longitudinal costae on disk or tubercles and costiform callosities on apical declivity; truncate at base. Legs short, subequal in length; tibiae slightly expanded toward apices, dentate on exterior margins, each with a large, arcuate spine at apex; posterior tarsi as long as, or longer than tibiae, apical segment of each shorter than preceding four segments united. Anterior coxae contiguous. Middle coxae narrowly separated. Posterior coxal cavities completely margined on first visible abdominal sternite. Intercoxal process of abdomen tubular or narrowly triangular. Body elongate, cylindrical.

Genotype.-Of Micrapate and Bostrychulus, Sinoxylon dinoderoides Horn. (Present designation.)

This genus is widely distributed and is found in the southern part of the United States, the West Indies, Mexico, Central and South America, Africa, and the Mediterranean region and at present con-

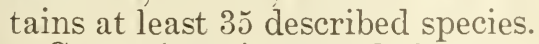

Casey (1898) erected the genus Micrapate for Sinoxylon dinoderoides Horn, Micrapate cristicauda new species, and Sinoxylon sim- 
plex Horn (the last belonging to the genus Amphicerus) without designating a genotype. Lesne (1899) erected the genus Bostrychulus for 18 species without designating a genotype, but he (1900) placed Bostrychulus Lesne as a synonym of Micrapate Casey, stating that Micrapate Casey had several months priority over Bostrychulus Lesne.

\section{KEY TO THE SPECIES OF MICRAPATE}

1. Apical contour of elytra (when viewed from above) distinctly angulated, the tips more or less emarginate _........ dinoderoides (Horn), p. 88. Apical contour of elytra (when viewed from above) rounded or very obtusely angulated, the tips conjointly broadly rounded.............

2. Pronotum longer than wide; dorsal surface of body sparsely pubescent xyloperthoides (Jacquelin-Duval), p. 89.

Pronotum not longer than wide, quadrate or slightly wider than long

3. Dorsal surface of body densely pubescent_._._ scabrata (Erichson), p. 90.

4. Sutural margins gibbose on apical declivity of elytra, the sides abruptly deflexed

Sutural margins not gibbose on apical declivity, uniformly elevated along entire length, the sides not abruptly deflexed.

5. Elytra distinctly pubescent; pronotum not wider than long. clypeus distinctly pubescent. ....... mexicana, new species, p. 91.

Elytra not distinctly pubescent; pronotum wider than long; clypeus not distinctly pubescent_...... brasiliensis (Lesne), p. 92.

6. Sutural gibbosity on apical declivity of elytra expanded laterally at middle of declivity

Sutural gibbosity on apical declivity of elytra not expanded laterally at middle of declivity _........ cristicauda Casey, p. 93.

7. Sutural gibbosity on apical declivity of elytra abruptly expanded at middle of declivity, bilobed on top_._._._._._. bilobata, new species, p. 94 .

Sutural gibbosity on apical declivity of elytra gradually expanded at middle of declivity, not bilobed on top........... labialis Lesne, p. 94.

\section{Micrapate dinOderoides (Horn)}

Sinoxylon dinoderoides Horn, 1878, Amer. Phil. Soc. Proc. 17: 542, 543.

Micrapate dinoderoides Casey, 1898, N. Y. Ent. Soc. Jour. 6: 66, 72, 73; Lesne, 1906, Abeille $30: 281$; 1938, in Junk (pub.), Coleopt. Cat., pt. 161, p. 45.

Male.-Dark reddish brown, underside of body usually in part brownish black, the antennae, palpi, and tarsi yellowish brown.

Head rather densely, coarsely punctate or granulose and sparsely clothed with short, recumbent, whitish hairs on clypeus and front of head, with long, longitudinal, parallel costae on occiput; clypeal suture obsolete; labrum finely, densely punctate.

Pronotum slightly transverse, widest at middle; sides broadly rounded, with a small, broad tooth at apical angles; posterior angles broadly rounded; surface sparsely clothed with short, erect or recumbent, inconspicuous hairs, densely, coarsely punctate on basal half, densely, irregularly dentate on apical half, the teeth broad, variable in size, semierect, and rasplike.

Elytra at base slightly narrower than pronotum at middle; sides vaguely expanded posteriorly, conjointly broadiy rounded at apices, with a vague emargination at sutural margins; apical contour (when viewed from above) distinctly angulated; surface not deeply depressed along sutural margin on apical declivity, coarsely, rather densely, rugosely punctate, the punctures coarser and more or less confluent on apical declivity, sparsely clothed with short, semierect, yellowish hairs on apical half; sutural margins on apical declivity not 
gibbose or expanded laterally at middle of declivity, uniformly elevated along entire length, coarsely rugose on dorsal surface, the sides not abruptly deflexed.

Body beneath coarsely, densely punctate; abdomen more finely punctate, densely clothed with long, recumbent, yellowish hairs, last visible sternite broadly rounded at apex.

Female.-Differs from the male in having the lateral margins of the elytra conjointly deeply arcuately emarginate at the apices, and the last visible abdominal sternite broadly, arcuately depressed posteriorly, with a rectangular emargination at the apex.

Length $3.75-1.5 \mathrm{~mm}$., width $1.2-1.5 \mathrm{~mm}$.

Type locality.-Camp Grant, Ariz.; type in the Horn Collection in the Academy of Natural Sciences of Philadelphia.

Distribution.-From material examined:

TExas: Brownsrille (C. Schaeffer, Hubbard and Schwarz, H. S. Barber, C. H. T. Townsend, and H. F. Wickham). Harlingen (R. A. Vickers). Santa Maria (T. D. Urbahus).

\section{Hosts.-None recorded.}

\section{Micrapate xyloperthoides (Jacquelin-Duval)}

Apate xyloperthoides Jacquelin-Dural, 1859, Glanures Entomologique 1: 40 (publication not seen) ; 1859-1863, Genera Coleopt. Europe, r. 3, Cat. p. 167; Perris, 18 7 , Larres Coléoptères, p. 219 ; Chobaut, 1891, Le Coléoptèriste, pp. 85-89, figs. 1-11.

Bostrychus xyloperthoides Zoufal, 1894, Wien. Ent. Ztg. 13: 41.

Bostrychulus xyloperthoides Lesne, 1899, Soc. Ent. de France Ann. (1S9S) 67: 596. 610-612, figs. 223, 243 ; Schilsky, 1899, in Küster and Kraatz, Kïfer Europas 36 : No. 88

Jicrapate xyloperthoides Lesne, 1901, Abeille 30:95-96, pl. 2. fig. 40 ; 1904, ibid. 30: 155; Reitter, 1911, Fauna Germanica, r. 3, pp. 303-304; Lesne, 1935, in Junk (pub.), Coleopt. Cat., pt. 161, p. 46.

Elongate, strongly shining, uniformly brownish black. sometimes reddish on apical declivity, the antennae, palpi, and tarsi yellowish brown.

Head sparsely, finely punctate, densely granulose, and sparsely clothed with short. recumbent, whitish hairs on clypeus and front of head: clypeus shallowly, arcuately emarginate in front; clypeal suture indicated at middle, obsolete at sides; labrum finely, densely punctate.

Pronotum slightly longer than wide, widest at middle, deeply arcuately emarginate in front; sides broadly rounded, with a small, broad tooth at apical angles: posterior angles broadly rounded: surface sparsely clothed with short, recumbent and semierect. inconspicuous, yellowish hairs, sparsely, finely punctate on basal half, densely, irregularly dentate on apical half, the teeth broad, semierect, variable in size, and rasplike.

Elytra at base slightly narrower than pronotum at middle: sides parallel, conjointly broadly rounded at apices; apical contour (when viewed from above) broadly rounded; surface finely, shallowly, rugosely punctate, the punctures finer and more obsolete on apical declivity, sparsely, irregularly clothed with short, recumbent, yellowish hairs; apical declivity broadly, shallowly depressed along sutural margins; sutural margins on apical declivity not gibbose or expanded laterally at middle, but broadly, uniformly elevated along entire length, the sides not abruptly deflexed. 
Abdomen beneath coarsely, densely punctate, densely, finely granulose between punctures, densely clothed with long, recumbent and erect, whitish hairs; last visible sternite broadly rounded at apex. Posterior tibiae with semierect hairs on outer surface. Posterior tarsi without long, fine hairs.

Length $3.5-5 \mathrm{~mm}$., width $1.2-1.5 \mathrm{~mm}$.

Type locality.-Southern France; type in the Paris Museum.

Distribution.-This species is distributed throughout the western Mediterranean region. Four specimens were intercepted at New York, November 8, 1934, in bamboo from Italy.

Hosts.-Perris (1877) reported the larvae in bamboo. Chobaut (1891) reported the species as mining in the giant reed (Arundo donax L.) in France. This species also lives in the wild grape.

\section{Micrapate scabrata (Erichson)}

Bostrichus scabratus Erichson, 184i, in Wiegmann, Arch. f. Naturgesch. 13 (1) : ST.

Bostrychulus scabratus Lesne, 1899, Soc. Ent. de France Ann. (1S98) 67: 596, 612-613, fig. 221.

Micra pate scabrata Lesne, 1938, in Junk (pub.), Coleopt. Cat., pt. 161, p. 46.

Bostrichus vitis Blanchard, 1851, in Gay, Hist. Chile 5:433-434; Germain, 1892, Soc. Sci. de Chili, Actes 2 (2) : 259.

Rhizopertha vitis Philippi, 1887, Cat. Coleopt. Chile, p. 105.

Male.-Dark reddish brown, sides and disk of pronotum, sides of elytra, and underside of body (except legs) blackish, the antennae and palpi brownish yellow.

Head densely, coarsely punctate, sparsely clothed with moderately long, recumbent, whitish hairs on front, with long, longitudinal, parallel costae on occiput; clypeus smooth and shining at middle, finely, densely, rugosely punctate posteriorly and at sides, clothed with a few long, recumbent, whitish hairs, arcuately emarginate in front, anterior angles acute; clypeal suture obsolete; labrum rather finely, sparsely punctate.

Pronotum quadrate, widest at basal third; sides broadly rounded, more strongly converging anteriorly, with a short, rather acute, semierect tooth at apical angles; posterior angles broadly rounded; surface sparsely clothed with yellowish hairs, which are short and erect on apical half, and long, recumbent toward posterior angles, vaguely, longitudinally grooved at middle, densely, finely punctate on basal half, densely, finely granulose, with numerous broad, semierect, rasplike teeth on apical half, the teeth rather acute at apices.

Elytra at base slightly narrower than pronotum at basal third; sides parallel, conjointly broadly rounded at apices; apical contour (when viewed from above) broadly rounded; surface broadly depressed along sutural margins on apical declivity, coarsely, densely punctate, rather densely clothed with moderately long, recumbent, yellow hairs; sutural margins on apical declivity very strongly gibbose but not expanded laterally at middle of declivity, dentate on dorsal surface, sides abruptly deflexed, the gibbosity obtusely angulated when viewed in profile.

Body beneath rather densely clothed with long, recumbent, whitish hairs; mesosternum and metasternum sparsely, coarsely punctate; abdomen densely, coarsely punctate, last visible sternite broadly rounded at apex. 
F'emale.-Differs from the male in having the sutural margins on the apical declivity of the elytra moderately gibbose, rugose but not dentate on the dorsal surface, the gibbosity gradually, broadly rounded when riewed in profile, and the surface of the apical declivity scarcely ciepressed along the sides of the margins.

Length $3.5-5.5 \mathrm{~mm}$., width $1.2-1.7 \mathrm{~mm}$.

Type locality.-Of scabratus, Peru; type was in the Berlin Museum. Of vitis, Illapel, Coquimbo, and Concepcion, Chile; type in the Paris Museum.

Distribution.-This species is recorded from Peru, western Bolivia, and northern Chile. Specimens of this species have been intercepted at New York in packing cases containing grapes from Chile and with corn on the cobs from Peru.

Hosts.-In Chile this species lives in the stems of grapes.

Blanchard (1851) described Bostrichus vitis from Illapel, Coquimbo, and Concepción, Chile, without designating any place as the type locality. Lesne (1899) placed Bostrichus vitis Blanchard (1851) as a synonym of Bostrychulus scabratus Erichson (1847).

Micrapate mexicana, new species

Male--Brownish black, elytra usually more reddish, and antennal club, palpi, and tarsi brownish yellow.

Head rery densely, finely punctate or granulose, sparsely clothed with long, semierect, whitish hairs on clypeus and front of head, with long, fine, longitudinal, parallel costae on occiput; clypeus broadly, shallowly emarginate in front; clypeal suture not distinct; labrum finely, sparsely punctate.

Pronotum quadrate, widest at middle, shallowly emarginate in front; sides broadly rounded, with a small, broad tooth at apical angles; posterior angles broadly rounded; surface sparsely clothed with short, recumbent, whitish hairs, densely, finely punctate on basal half, densely, irregularly dentate on apical half, the teeth broad, semierect, variable in size, acute at apices, and rasplike.

Elytra at base slightly narrower than pronotum at middle; sides nearly parallel, broadly, conjointly rounded at apices; apical contour (when viewed from above) broadly rounded;-surface sparsely clothed with moderately long, recumbent, yellowish hairs, densely, coarsely, confluently punctate over entire surface; apical declivity arcuately deflexed and not depressed along sutural margins; sutural margins on apical declivity not gibbose or expanded laterally at middle, but narrowly, uniformly elevated along entire length, the sides not abruptly deflexed.

Abdomen beneath finely, densely punctate, smooth between punctures, rather densely clothed with long, recumbent, whitish hairs, with a few long, erect hairs intermixed; last visible sternite broadly rounded at apex. Posterior tibiae and tarsi with long, fine hairs.

Female.-Differs from male in having a small vague depression at apex of last visible abdominal sternite.

Length 4-6 mm., width $1.5-2 \mathrm{~mm}$.

Type locality.-Mexico.

Type, allotype, and paratypes.-In the United States National Museum, No. 58315 . 
Described from 20 specimens (1 male type). Fifteen specimens reared from bamboo (Arundinaria longifolia) in storage at Hoboken, N. J., shipped from Mexico; three specimens intercepted at Laredo, 'Tex., in bamboo poles from Mexico; and two specimens intercepted at Nogales, Ariz., in bamboo from Mexco.

'This species is allied to Micrapate brasitiensis (Lesne), but differs from that species in having the clypeus and front of the head clothed with long, semierect hairs, the clypeus broadly and shallowly emarginate in front, the clypeal suture not distinct, the pronotum quadrate and not wider than long, and the upper surface of the body clothed with distinct hairs.

\section{Micrapate brasiliensis (Lesne)}

Bostrychulus brasiliensis Lesne, 1899, Soc. Ent. de France Ann. (1898) 67 : 594, 599-600, figs. 226-228.

Micrapate brasiliensis Lesne, 1938, in Junk (pub.), Coleopt. Cat., pt. 161, p. 44.

Male.-Brownish black to black, sometimes with base of elytra and abdomen in part reddish, the antennae, palpi, labrum, and tarsi yellowish or reddish brown.

Head very densely, finely punctate or rugose, with long, longitudinal, parallel costae on occiput, and nearly glabrous on clypeus and front of head; clypeus deeply, arcuately emarginate in front; clypeal suture distinct at middle, obsolete at sides; labrum very finely, sparsely punctate.

Pronotum slightly wider than long, widest behind middle, shallowly emarginate in front; sides broadly rounded, more strongly converging anteriorly, with a small, broad tooth at apical angles; posterior angles broadly rounded; surface nearly glabrous, coarsely, densely punctate on basal half, the punctures sparser toward sides, densely, irregularly dentate on apical half, the teeth broad, semierect, variable in size, and rasplike.

Elytra at base slightly narrower than pronotum behind middle; sides nearly parallel, conjointly broadly rounded at apices; apical contour (when viewed from above) broadly rounded; surface glabrous, densely, coarsely, confluently punctate over entire surface; apical declivity arcuately deflexed, and not depressed along sutural margins; sutural margins on apical declivity not gibbose or expanded laterally at middle, but narrowly, uniformly elevated along entire length, the sides not abruptly deflexed.

Abdomen beneath coarsely, densely punctate, smooth between punctures, sparsely clothed with rather short, recumbent, whitish hairs; last visible sternite broadly rounded at apex. Posterior tibiae with erect hairs on outer surface. Posterior tarsi with long, fine hairs.

Female.-Differs from the male in having the last visible abdominal sternite broadly rounded at the apex, with a small, round fovea, which is feebly, longitudinally carinate posteriorly.

Length 4-5.5 mm., width 2-2.2 mm.

Type locality.-Brazil, various localities in the States of Bahia, Minas Geraes, and São Paulo; types scattered in various collections and museums.

Distribution.-Recorded only from southern Brazil. Two specimens were intercepted at New York, March 11, 1925, in dried tree roots. 
Hosts.-Nothing has been recorded on the habits of this species.

Lesne (1899) described brasitiensis from a series of specimens from many localities in southern Brazil without designating the type locality, and these types are scattered in many different European collections.

\section{Micrapate cristicauda Casey}

Jicrapate cristicauda Caser, 1898, N. Y. Ent. Soc. Jour. 6: 72-73; Lesne, 1906, Abeille 30: 281; 1938, in Junk (pub.) Coleopt. Cat., pt. 161, p. 45.

Bostrychulus dinoderoides Lesne, 1899 (not Horn), Soc. Ent. de France Ann. (1898) 67: 594, 601-602, figs. 229-230.

Male.-Dark reddish brown to brownish black, elytra, antennae, palpi, and tarsi usually paler.

Head rather densely, coarsely punctate and with a few short, recumbent, inconspicuous hairs on clypeus and front of head, with long. longitudinal. parallel costae on occiput: clypeus deeply, arcuately emarginate in front: clypeal suture obsolete; labrum finely, densely punctate.

Pronotum slightly transrerse. widest at middle; sides broadly rounded, more strongly converging anteriorly, with a small, broad tooth at apical angles: posterior angles broadly rounded: surface sparsely clothed with short, erect and recumbent, inconspicuous hairs, coarsely, sparsely punctate on basal half, rather densely, irregularly dentate on apical half, the teeth broad, variable in size, semierect. and rasplike.

Elytra at base raguely narrower than pronotum at middle; sides nearly parallel, conjointly broadly rounded at apices: apical contour (when riewed from abore) obtusely rounded; surface not rery deeply depressed along sutural margins on apical declirity, coarsely, rather densely punctate on disk, coarsely, confluently punctate and rugose on apical declivitr, sparsely clothed with short, recumbent, rellowish hairs on apical half; sutural margins on apical declivity strongly gibbose but not distinctly expanded laterally at middle of declivity, coarsely rugose on dorsal surface, sides abruptly deflexed, the gibbosity gradually, broadly rounded when riewed in profile.

Abdomen beneath coarsely, densely punctate, sparsely clothed with short, recumbent, yellowish hairs; last risible sternite broadly rounded at apex, rather densely clothed with moderately long. recumbent and erect yellowish hairs.

Female.-Differs from the male in having the last visible abdominal sternite smooth at the apex, with a small depression in front of the smooth area.

Length $3.6-4.5 \mathrm{~mm}$., width $1.2-1.5 \mathrm{~mm}$.

Type locality.-District of Columbia: type in the Casey Collection in the United States National Museum. Distribution.-From material examined:

District of Columbia : Washington, July 17. 1929 (type).

Marylard: Chesapeake Beach. September (L. L. Buchanan).

VIRGINIA: Rosslin, June 3 (F. H. Chittenden).

Florida: Crescent City (Hubbard and Schwarz). Manatee County. March 19. 1930 (R. F. Tinker).

Host.-This species was reared in large numbers from dead grape at Washington, D. C. 


\section{Micrapate Bilobata, new species}

Male.-Uniformly dark reddish brown, underside of body in part slightly darker, the antennae and palpi brownish yellow.

Head coarsely, rather sparsely punctate, sparsely clothed with short, recumbent, inconspicuous hairs on front, with long, longitudinal, parallel costae on occiput; clypeus sparsely, finely, shallowly punctate, clothed with a few inconspicuous hairs, arcuately emarginate in front, anterior angles acute; clypeal suture feebly indicated; labrum sparsely, finely punctate.

Pronotum quadrate, widest at middle, more strongly converging anteriorly; posterior angles broadly rounded; surface clothed with a few very short, inconspicuous hairs, coarsely, sparsely punctate at sides on basal half, imbricate punctate on median part of basal half, irregularly dentate on apical half, the teeth variable in size, broad, semierect, rather acute at apices, and rasplike; with four larger teeth on each side along lateral margins.

Elytra at base subequal in width to pronotum at middle; sides vaguely expanded posteriorly, conjointly broadly rounded at apices; apical contour (when viewed from above) broadly rounded; surface deeply, narrowly depressed along sutural margins on apical declivity, coarsely, densely, uniformly punctate, with a few short, recumbent, inconspicuous hairs on apical declivity; sutural margins on apical declivity strongly gibbose and abruptly expanded laterally at middle of declivity, sides abruptly deflexed, the gibbosity smooth on dorsal surface, divided into two lobes by a deep, median groove, and obtusely rounded when viewed in profile.

Body beneath finely, densely granulose, coarsely, rather densely, shallowly punctate, sparsely clothed with recumbent, yellowish hairs, which are longer at sides of abdominal sternites; last visible abdominal sternite broadly rounded at apex.

Female.-Unknown.

Length $5 \mathrm{~mm}$., width $1.6 \mathrm{~mm}$.

Type locality.-Nueces River, Zavala County, Tex.

Type.--In the United States National Museum, No. 58314.

Described from a single specimen, which seems to be a male, collected April 30, 1910, by F. C. Pratt.

\section{Micrapate labialis Lesne}

Micrapate labialis Lesne, 1906, Abeille 30: 271, 278-279, fig. S; 193S, in Junk (pub.), Coleopt. Cat., pt. 161, p. 45 ; 1939, Rev. Franç. Ent. 6: 106-107, fig. 11. Xylopertha scapularis Gorham, 18s3, Biol. Centr.-Amer., Coleopt. 3 (2) : 216 (part).

Male.-Uniformly reddish brown to brownish black, with disk of pronotum, base, apical declivity, sutural and lateral margins of elytra, and legs reddish, the antennae, palpi, and tarsi brownish yellow.

Head rather densely, coarsely punctate and sparsely clothed with short, recumbent, inconspicuous hairs on clypeus and front of head, with long, longitudinal, parallel costae on occiput; clypeus arcuately emarginate in front, anterior angles acute; clypeal suture sometimes vaguely indicated at middle; labrum rather finely, sparsely punctate.

Pronotum quadrate, widest at middle; sides broadly rounded, more strongly converging anteriorly, with a short, broad, semierect tooth at apical angles; posterior angles broadly rounded; surface sparsely 
clothed with short, recumbent, inconspicuous hairs, coarsely, densely punctate on basal half, rather densely, irregularly dentate on apical half, the teeth broad, variable in size, semierect, and rasplike.

Elytra at base subequal in wirth to pronotum at middle; sides parallel, conjointly broadly rounded at apices; apical contour (when viewed from above) broadly rounded; surface deeply, narrowly depressed along sutural margins on apical declivity, coarsely, densely, rugosely punctate on disk, more coarsely and confluently punctate on apical declivity, clothed with a few very short, inconspicuous hairs; sutural margins on apical declivity strongly gibbose and arcuately expanded laterally at middle of declivity, smooth and shining, at least on anterior half of dorsal surface, sides abruptly deflexed, the gibbosity broadly rounded when viewed in profile.

Body beneath coarsely, rather densely punctate, sparsely clothed with moderately long, recumbent, whitish hairs ; last visible abdominal sternite broadly rounded at apex.

Female.-Differs from the male in having a vague, pubescent depression at the apex of the last visible abdominal sternite.

Length $3.2-5 \mathrm{~mm}$., width $1.2-1.5 \mathrm{~mm}$.

Type locality.-Torola and San Geronimo, Guatemala; type in the British Museum.

Distribution.-This species has been intercepted a great many times at New York, N. Y., Philadelphia, Pa., Santa Fe, N. Mex., and Nogales, Ariz., in shipments from Mexico. Lesne (1939) lists this species from Mexico and Guatemala.

Hosts.- Specimens intercepted were usually in wooden crates composed of Baccharis or Sambucus wood, and adults were also found in the stems of Sambucus sp. from Mexico.

Lesne (1906) described labialis from two specimens in the British Museum collected by G. C. Champion in Guatemala at Torola (300 meters) and San Geronimo (900 meters) without designating either place as the type locality.

\section{Genus APATIDES Casey}

Apatides Casey, 189S, N. Y. Ent. Suc. Jour. 6: 66, 70-71; 1914, Mem. Coleopt., v. 5, pp. 359-360 ; Lesne, 1899, Soc. Ent. de France Ann. (1898) 67: 526, 552553 (part) ; 1900, Soc. Ent. de France Bul., pp. 46-47; 1938, in Junk (pub.), Coleopt. Cat., pt. 161, pI. 42-43.

Head strongly convex on occiput, broadly, transversely concave behind eyes, abruptly deflexed behind clypeus, deeply inserted in prothorax, not visible from above; front separated from vertex by a transversely arcuate ridge; clypeus slightly convex, broadly transverse, truncate in front, anterior angles rectangular; clypeal suture distinct; labrum strongly transverse, truncate in front and densely ciliate with large yellow hairs in front; margins of buccal cavities not dentate below eyes; mandibles more or less attenuate toward apices; eyes oval, globose, strongly projecting. Intenna 10-segmented; first and second segments robust, first elongate, second oval, shorter than first; third to seventh segments short, narrower than second, oval or transverse, subequal to one another in length; last three segments forming a broad, loose, compressed club, each with two more or less distinct, round, sensory depressions on each surface, eighth and ninth subtriangular, truncate at apices, the ninth shorter than eighth, tenth 
oblong, subequal in length to and narrower than ninth. Pronotum strongly convex, emarginate in front, truncate at base, dentate anteriorly, not transversely depressed behind anterior margin; sides not margined. Scutellum small, quadrate. Elytra strongly convex, without tubercles or costiform callosities on apical declivity. Legs, short, subequal in length; tibiae slightly expanded toward apices, dentate on exterior margins; each with a large, arcuate spine at apex; posterior tarsi usually as long as, or longer than tibiae, apical segment of each shorter than preceding four segments united. Anterior coxae contiguous. Middle coxae rather broadly separated. Posterior coxal cavities completely margined on first visible abdominal sternite. Intercoxal process of abdomen tubular or narrowly triangular. Body elongate, cylindrical.

Genotype.-Amphicerus fortis LeConte. (Original designation.)

Casey (1898) erected Apatides for Amphicerus fortis LeConte, Apitides robustus new species, and Apatides puncticeps new species, and designated fortis as the genotype. Lesne (1898) erected Bostrychopsis for 16 species without designating a genotype. He divided his genus into 6 groups, of which group VI included only fortis LeConte. Lesne (1900) stated that the paper by Casey had priority over his paper, but used A patides only for group VI of his Bostrychopsis, and retained Bostrychopsis for the other 5 groups.

\section{ApATIDES FORTIS (LeConte)}

Amphicerus fortis LeConte, 1866, Smithsn. Inst. Misc. Collect. 167 : 101; Horn, 1878, Amer. Phil. Soc. Proc. 17 : 547.

Apatides fortis Casey, 1898, N. Y. Ent. Soc. Jour. 6: 66, 70, 71: Mm. Coleopt., v. 5, p. 360 ; Lesne, 1938, in Junk (pub.), Coleopt. Cat., pt. 161, p. 42 ; Anderson, 1939, Wash. Acad. Sci. Jour. 29 (9) : 390, figs. 22, 26, 46 (larvae).

Bostrychopsis fortis Lesne, 1899, Soc. Ent. de France Ann. (1898) $67: 552-553$, figs. 139, 168.

Apatides fortis Casey, 1898, N. Y. Ent. Soc. Jour. 6:66, 70, 71; Mem. Coleopt., v. 5, p. 360 ; Lesne, 1938, in Junk (pub.), Coleopt. Cat., pt. 161, p. 43. (New synonymy.)

Apatides puncticeps Casey, 1898, N. Y. Ent. Soc. Jour. 6: 70-71; 1914, Mem. Coleopt., v. 5, p. 360 ; Lesne, 1938, in Junk (pub.), Coleopt. Cat., pt. 161, p. 43. (New synonymy.)

A patides pollens Casey, 1914, Mem. Coleopt., v. 5, pp. 359-360 ; Lesne, 1938, in Junk (pub.), Coleopt. Cat., pt. 161, p. 42. (New synonymy.)

Male.-Black, with a slight reddish tinge, underside of body sometimes more reddish, the palpi and antemnae brownish yellow; dorsal surface of body glabrous.

Head much narrower than pronotum, coarsely, sparsely punctate anteriorly, smooth and shining in transverse concavity, with short, longitudinal, parallel costae on occiput; clypeus coarsely, rather densely punctate, anterior angles rectangular.

Pronotum quadrate, strongly convex, widest near middle, strongly deflexed on apical half; sides broadly rounded, more strongly converging anteriorly, produced into a large unciform horn at apical angles; posterior angles rectangular, or obtusely rounded; surface rugose or coarsely, deeply punctate at sides, with large scalelike granules on disk, the granules flattened on basal half, larger, semierect, and more tuberculate on apical half, and with a number of broad, rasplike tubercles on each side in front of middle.

Elytra at base subequal in width to pronotum at middle, slightly sinuate at base, without longitudinal costae; lateral and sutural mar- 
gins slightly elevated on apical declivity; sides parallel, conjointly broadly rounded at apices; surface coarsely, deeply, densely, irregularly punctate, the punctures sometimes becoming very fine and obsolete on elytral declivity; apical angles thickened, each with a punctiform fossa from which arises a tuft of yellow hairs.

Abdomen beneath densely, finely punctate, sparsely clothed with short, recumbent, yellowish hairs, which are denser along apical margins of sternites; metasternum finely, vaguely punctate; second segment of posterior tarsus slightly longer than last segment, the third twice as long as fourth.

Female.-Differs from the male in having the apical declivity of the elytra more densely and coarsely punctate, and the apex of each elytron thickened but without a punctiform fossa.

Length 9-20 mm.. width $3.5-7 \mathrm{~mm}$.

Type locality.-Of fortis, Cape San Lucas, Lower California : type in LeConte Collection in the Museum of Comparative Zoology, Cambridge, Mass. Of pollens, Bill Williams Fork, Ariz., puncticeps, Arizona, no definite locality, and robustus. El Paso, Tex.; types in the Casey Collection in the United States National Museum.

Distribution.-From material examined:

Arizoxa: Yuma, Oracle, Tucson. Catalina Springs, Sabino Canyon, Redington, Nogales, Phoenix. and Bill Williams Fork (tspe of pollens).

Califorxia: San Diego County, Bard, Imperial Counts, Palm Springs, Indio, and Paramint Talles.

Lower Califoria : San Jose del Cabo.

New Mexico: Demming.

Texas: Sabinal, Del Rio, Knippa, San Antonio, Harwood, and El Paso (type of robustus).

UтAн: Hanksrille.

Mexico: Many localities.

Costa Rlca: Santa Elena, Taboga.

Nicaragua : Managua City.

Colombia : Rio Frio.

Hosts.-This species has been reared from mesquite (Prosopis spp.) and paloverde (Cercidium spp.). Adults are attracted to light from May to Norember.

LeConte (1866) described fortis from two specimens collected by Xántus at Cape San Lucas, Lower California. Casey (1898) described robustus from a female collected at El Paso. Tex.. and puncticeps from a single female from Arizona, without a definite locality. In 1914 Casey described pollens from a single male collected at Bill Williams Fork, Ariz., by F. H. Snow.

In fortis the size and shape of the posterior angles of the pronotum are quite variable. In reared series of this species the posterior angles of the pronotum are either rounded or more or less rectangular and in some cases are projecting. Some specimens are more or less opaque, but this is due to being somewhat greasy.

The types of the three Casey species have been examined and no constant characters can be found for separating them from fortis LeConte.

\section{Genus BOSTRYCHOPSIS Lesne}

Bostrychopsis Lesne, 1899. Soc. Fint. de France Ann. (1S9S) 67: 44t, 52t-553: Schilsky, 1899, in Küster and Kraatz, Käfer Europas 36: p. UU ; Lesne, 1901, $842409-50-7$ 
Abeille 30 : 87, 94; Jakobson, 1913, Käfer Russland, pt. 10, pp. 803, 805 ; Lesne, 1924, Bostrychides de l'Afrique Tropicale Française, pp. 114, 137-145; 1938, in Junk (pub.), Coleopt. Cat., pt. 161, pp. 38-40.

Head strongly convex on vertex, transversely flattened behind eyes, deeply inserted in prothorax, not visible from above, with or without a short, transverse elevation at middle behind clypeus; clypeus slightly convex, broadly truncate or vaguely, shallowly emarginate in front, anterior angles obtuse or rectangular; clypeal suture distinct at middle, obsolete at sides; labrum short, strongly transverse, subtruncate and densely ciliate with long, yellow hairs in front; margins of buccal cavities not dentate below eyes; mandibles more or less attenuate toward apices; eyes oval, globose, strongly projecting. Antenna 10-segmented; first and second segments robust, first elongate, second oval, shorter than first; third to seventh segments short, oval, transverse, narrower than second segment, subequal in length to one another; last three segments forming a broad, loose, compressed club, subequal in length to one another, each with two small, round sensory depressions on each surface, eighth and ninth subquadrate, truncate at apices, tenth oblong, slightly narrower than ninth. Pronotum strongly convex, truncate or emarginate in front, truncate at base, dentate anteriorly, not transversely depressed behind anterior margin; sides not margined. Scutellum small, quadrate. Elytra strongly convex, with or without costiform callosities on apical declivity. Legs short, subequal in length; tibiae slightly expanded toward apices, anterior pair dentate on exterior margins, each with a large, arcuate spine at apex; posterior tarsi as long as, or longer than tibiae, apical segment of each shorter than preceding four segments united. Anterior coxae contiguous. Middle coxae narrowly separated. Posterior coxal cavities completely margined on first visible abdominal sternite. Intercoxal process of abdomen tubular or narrowly triangular. Body elongate, cylindrical.

Genotype.-Bostrychus parallelus Lesne. (Present designation.)

Lesne (1899) erected this genus for 16 species without designating a genotype. Of these species 8 are from the Old World, 1 from Australia, 6 from South America, and 1 from North America. The last species (fortis.Leconte) was designated by Casey (1898) as the genotype of his new genus Apatides.

\section{KEY TO THE SPECIES OF BOSTRYCHOPSIS}

Dorsal surface of body pubescent; clypeus very densely clothed with short, erect hairs ....... Dorsal surface of body glabrous; clypeus not clothed with short, erect hairs parallela (Lesne), p. 99.

\section{Bostrychopsis tetraOdon (Fairmaire)}

Apate (Bostrichus) tetraodon Fairmaire, 1883, Le Naturaliste, 5: 205; 1883, Soc. Ent. de France Ann. (ser. 6) 3: 96-97.

Bostrychopsis tetraodon Lesne, 1899, Soc. Ent. de France Aun. (1898) 67: 525, 530, figs. 143-144; 1938, in Junk (pub.), Coleopt. Cat., pt. 161, p. 39.

Male.-Uniformly brownish black, with antennae more reddish brown and antennal clubs and palpi brownish yellow; dorsal surface of body rather densely clothed with short, recumbent, yellowish hairs.

Head much narrower than pronotum, broadly, transversely concave behind eyes, with a short, transverse, serrate elevtation at middle along 
anterior margin, densely, coarsely granulose on front (except concare area, which is nearly smooth), and with short, longitudinal, parallel costae on occiput; clypeus flat, opaque, with short, longitudinal ridges along anterior margin, densely, very finely punctate, very densely clothed with short, erect, rellowish hairs; clypeal suture distinct.

Pronotum quadrate, strongly conrex, widest near middle, strongly deflexed anteriorly, deeply, arcuately emarginate in front; sides broadly rounded, more strongly converging anteriorly, with a large, broad, unciform horn at apical angles; posterior angles broadly rounded; surface densely imbricate-punctate on basal half, densely, irregularly dentate on apical declivity, the teeth broad, semierect, variable in size, and rasplike.

Elytra at base subequal in width to pronotum at middle, truncate at base; sides raguely expanded posteriorly, conjointly broadly rounded at apices, the margins sinuate, thickened, and strongly elerated along apical declivity; sutural margins slightly, broadly, uniformly elerated on apical declivity; surface coarsely, densely, irregularly punctate on basal two-thirds, finely, sparsely punctate on apical declivity, with two or three coarse punctures on each side along sutural margin; each elytron with two long tubercles along anterior margin of apical declivity, the tubercles rather acute at apices, and the lateral one slightly arcuate.

Body beneath densely, finely punctate, densely clothed with rather long, recumbent, yellowish hairs; last risible abdominal sternite broadly rounded at apex. Anterior and posterior tarsi with long hairs on underside.

Female.-Differs from the male in having the pronotum truncate in front and not produced into a horn at apical angles, the apical declivity arcuately deflexed, coarsely, and densely punctate. and the apical margins scarcely elevated, but sinuately rounded with a small tooth at the sutural angles, and without tubercles along the anterior margin of the declivity, and the anterior and posterior tarsi without long hairs on the underside.

Length 8-14 mm., width $3-4.5 \mathrm{~mm}$.

Type locality.-Choa, Abyssinia: type in the Paris Museum.

Distribution.-This species has been recorded from Abyssinia and Egypt. One specimen was intercepted at New York, July 23, 1938, in a wooden toy supposed to have come from Trinidad.

Ho.sts.-Nothing has been recorded on the habits of this species.

Bostrychopsis paralieli (Lesne)

Bostrychus parallelus Lesne, 1895, Soc. Ent. de France Ann. 64: 174; 1897, Soc. Ent. de Belg. Ann. 41: 18.

Bostrichus parallelus Stebbing, 1903. Notes on Insects that Affect Forestry (India), No. 2, pp. 174-175, pl. 8, fig. 2.

Bostrychopsis parallela Lesne, 1S99, Soc. Ent. de France Ann. (1S08) 67: 532 , 534-536, figs. 148-153; 1904. Mission Parie Indo-Chine, Ent. Ser. 3: 106; Lefroy, 1909, Indian Insect Life, p. 316 ; Stebbing. 1914, Indian Forest Inserts. pp. 145-146, fig. 93; Snvder. 1927, U. S. Nept. Aør. Bul. 1490, p. 30. fis. 32a; Gardner, 1933, Indian Forest Rec.. Ent. Ser. If (9): 13, 14, pl. 4, figs. 50, 51 (larrae): Beeson, 1935, Indian Forester 61 (4): 253; Beeson and Bhatia. 1937. Indian Forest Rec., Ent. (n. ser.) 2: 225, 229, 232, 310, 313, 31s, 320; Lesne, 1938, in Junk (pub.), Coleopt. Cat., pt. 161, p. 39.

Male.-Uniformly black, sometimes with a slight reddish tinge, the palpi and antennae reddish brown; dorsal surface of body glabrous. 
Head narrower than pronotum, smooth behind clypeus, with short, longitudinal costae on occiput; clypeus sparsely, shallowly punctate, not clothed with short, erect hairs, anterior angles rectangular; clypeal suture distinct at middle, obsolete at sides.

Pronotum quadrate, strongly convex, widest at middle, strongly deflexed anteriorly, arcuately emarginate in front; sides broadly rounded, with a large, broad, unciform horn at apical angles; posterior angles broadly rounded; surface sparsely, irregularly punctate at sides on basal half, densely, coarsely imbricate-punctate at middle on basal half, densely, irregularly dentate on apical declivity, the teeth broad, semierect, and rasplike, with three or four larger teeth on each side toward lateral margin.

Elytra at base subequal in width to pronotum at middle, truncate at base; sides vaguely expanded posteriorly, conjointly broadly rounded at apices; the margins sinuate, thickened, and strongly elevated along apical declivity; sutural margins slightly, broadly uniformly elevated on apical declivity; surface coarsely, densely, deeply punctate, the punctures more or less arranged in rows on disk; each elytron with two more or less distinct costiform callosities along anterior margin of apical declivity.

Body beneath densely, finely punctate or rugose; abdomen rather densely clothed with short, recumbent, yellowish hairs, the hairs much longer at apex of last visible sternite which is broadly rounded at apex; second segment of posterior tarsi distinctly broader than last segment.

Female.-Differs from the normal male in having a densely pubescent spot on the head and a short, transverse elevation at the middle behind the clypeus, the pronotum truncate in front and not produced into a horn at the apical angles and the apical declivity of the elytra arcuately deflexed and,without costiform callosites along the anterior margin.

Length 9-13 mm., width $3.5-4.5 \mathrm{~mm}$.

Type localities.-Indo-China, Hindostan, Formosa, Sumatra and the Philippines; types in the Brussells and Paris Museums. The specimen from Indo-China is here designated as lectotype.

Distribution.-This species has been recorded from India, Hindostan, Indo-China, China, Malay Peninsula, Philippines, Borneo, Sumatra, Java, Soembawa, Flores, Celebes, and Makassar. Adults have been intercepted at Washington and New York in dry bamboo from the Orient and the Philippines.

Hosts.-Beeson and Bhatia (1937) recorded this species in Bambusa arundinacea, Dendrocalamus strictus, Smilax sp., Boswellia serrata, Mallotus phitippinensis, Mangifera indica, and Pterocarpus indicus, and Lesne (1899) recorded it in the roots of Smilax china. This species is primarily a borer in dry bamboos, especially those of large diameter used for tent poles, army telegraph poles, and in the thatched roofs of bungalows.

Lesne (1895) described paralletus from specimens from widely distributed localities, without designating any as the type locality.

In this species it is difficult to determine the sex of some examples without dissection. Often the males have a mixture of the male and 
female external characters. The male sometimes differs from the normal male in not having the horns on the pronotum, the horns being replaced by two teeth, and the elytra without the marginal costiform callosities, while in other specimens the horn is replaced by a tooth and the marginal callosities are present on the elytral declivity as in the normal males.

\section{Tribe XYloperthini}

Xyloperthini Lesne, 1921, Assoc. Franç. pour l'Avanc. des Sci., Cong. de Strasbourg (1920), p. 288; 1924, Bostrychides de l' Afrique 'Tropicale Française, pp. 111, 208-238; 1938, in Junk (pub.), Coleopt. Cat., pt. 161, pp. 55-68.

This is a rather large tribe of Bostrichidae, containing many genera, which are found in all parts of the world. Species belonging to 12 of these genera are either established in the United States or have been intercepted in commerce.

\section{KEY TO THE GENERA OF XYLOPERTHINI}

1. Pronotum without a carina along lateral margins, or the carina only indistinctly indicated at posterior angles . . . . . . . . . ...........

Pronotum with a very distinct carina along lateral margins posteriorly, sharply bent at posterior angles and slightly prolonged along base

2. Antennal club composed of 4 segments....- Tetrapriocera Horn, p. 102.

Antennal club composed of 3 segments

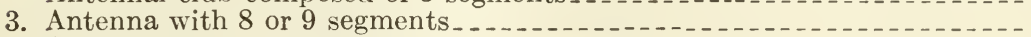
Antenna with 10 segments

4. Antenna with 9 segments. Scobicia Lesne, p. 104.

5. Segments of antennal club with sensory depressions on each surface .... Segments of antennal club without sensory depressions on either surface _..................... Xyloperthella, new name, p. 116.

6. Apical declivity of elytra trituberculate on each side, Apical declivity of elytra bituberculate on each side .............

7. Lateral submargin on apical declivity of elytra very strongly elevated and acutely, angularly separated at sutural angles; front of head convex in both sexes; antennae densely pubescent_- Xyloprista Lesne, p. 117.

Lateral submargin on apical declivity of elytra not strongly elevated or angularly separated at sutural margins.

8. Tubercles along anterior margin of apical declivity of elytra costiform, cylindrical, all obtuse at apices; antenna densely clothed with long hairs; female with front of head flattened or concave, and anterior margin of pronotum with long hairs . . . . . Xylomeira Lesne, p. 119.

Tubercles along anterior margin of apical declivity of elytra subtriangular, all or at least 1 pair spinose at apices; antenna without, or sparsely clothed with short hairs; female with front of head convex, and anterior margin of pronotum without long hairs

Xylobiops Casey, p. 121.

9. First 2 segments of antennal club elongate, the first subtriangular; female with front of head flattened or concave, and last visible abdominal sternite not emarginate at apex_..... Dendrobiella Casey, p. 127.

First 2 segments of antennal club subrounded or oval; female with front of head convex, and last visible abdominal sternite very deeply emarginate at apex................ Xyloblaptus Lesne, p. 130.

10. Lateral margins of elytra very deeply, irregularly emarginate near apices........... Xylion Lesne, p. 133.

Lateral margins of elytra not emarginate near apices . 11. First 2 segments of antennal club elongate; front of head of female
with erect hairs

First 2 segments of antennal club transverse; front of head of female without erect hairs................... Yylopsocus Lesne, p. 139. 


\section{Genus TETRAPRIOCERA Horn}

Tetrapriocera Horn, 1878, Amer. Phil. Soc. Proc. 17 : 541, 544 545, fig. ; LeConte and Horn, 1883, Smithsn. Inst. Misc. Collect. 507: 228; Casey, 1898, N. Y. Ent. Soc. Jour. 6: 66, 67; Lesne, 1901, Soc. Ent. de France Ann. (1900) 69: 475, 481-489, figs. 261-270; 1938, in Junk (pub.), Coleopt. Cat., pt. 161, p. 56.

Head deeply inserted in prothorax, not visible from above; clypeus strongly transverse, sinuate in front, with a small tooth on each side at base of labrum; labrum short, truncate, and densely ciliate with long, yellow hairs in front; mandibles more or less attenuate toward apices; eyes very large oval, globose, strongly projecting. Antenna rather long, 11-segmented, rather densely clothed with long erect hairs; first and second segments robust, first elongate, arcuate, flattened beneath, second oval or quadrate, much shorter than first; third to serenth segments small, compact, transverse, and united shorter than first; last four segments forming a large, loose, compressed club, the segments subequal in length to one another, eighth to tenth oblong, or subtriangular, each with two round sensory depressions on each surface, the apical segment narrowly elongate. Pronotum strongly convex, not transversely depressed behind anterior margin, truncate or emarginate in front, truncate at base, dentate anteriorly; sides not margined. Scutellum small, quadrate. Elytra strongly convex, each elytron trituberculate along anterior margin of apical declivity. Legs short, subequal in length; tibiae expanded toward apices, dentate on exterior margins, each with a large, arcuate spine at apex; posterior tarsi as long as, or longer than tibiae, apical segment of each shorter than preceding four segments united. Anterior coxae contiguous. Middle coxae narrowly separated. Intercoxal process of abdomen lamellate. Body elongate, cylindrical.

Genotype.-Tetrapriocera schwarai Horn. (Monobasic.)

This genus contains five species, only one of which has been found in the United States.

\section{TETRAPRIOCERA LONGICORNIS (Olivier)}

Bostrichus longicornis Olivier, 1795, Entomologie, v. 4, Gen. 77, pp. 15-16, pl. 3, figs. 18a, b, c.

Xylopertha longicornis Chevrolat, 1861, Soc. Ent. de France Ann. (ser. 4) 1: 392. Tetrapriocera longicornis Gorham, 1883, Biol. Centr.-Amer., Coleopt., v. 3, pt. 2, p. 218, pl. 10, fig. 20 ; Hubbard, 1888, Ent. Amer. 4: 95-96; Gorham, 1898, Zool. Soc. London Proc., p. 329 ; Casey, 1898, N. Y. Ent. Soc. Jour. 6 : 67 ; Lesne, 1937, Soc. Ent. de France Bul. 42 : 239; 1938, in Junk (pub.), Coleopt. Cat., pt. 161, p. 56 ; Belkin, 1940, Ent. News $51: 192$.

Tetrapriocera schwarzi Horn, 1878, Amer. Phil. Soc. Proc. 17 : 545, fig.; Lesne, 1896, Soc. Ent. de France Bul., p. 335.

Tetrapriocera tridens Lesne (not Fabricius), 1901, Soc. Ent. de France Ann. (1900) 69: 482, 483-486, figs. 261-265.

Apate rufescens Dejean, 1835, Cat. Coleopt., ed. 3, p. 309 ; 1836, ed. 3 rev., p. 334.

Male.-Strongly shining, pale reddish brown, except apical declivity of elytra, anterior tibiae in part, and sometimes front of head, which are dark reddish brown; antennae and palpi usually brownish yellow.

Head slightly convex, with two small tubercles placed transversely at middle near anterior margin, densely, finely punctate and rugose on front, with short, longitudinal, parallel costae on occiput, sparsely 
clothed with short, recumbent, whitish hairs; clypeus depressed at middle along clypeal suture, more finely, and less densely punctate than front of head, sparsely clothed with short, recumbent, whitish hairs; clypeal suture distinct, strongly depressed at middle.

Pronotum quadrate, widest at middle; sides broadly rounded posteriorly, more strongly converging anteriorly, with a broad, unciform tooth at apical angles; posterior angles broadly rounded; anterior margin broadly, arcuately emarginate; surface sparsely clothed with short, erect, inconspicuous hairs on apical half, very finely, sparsely punctate on each side at basal half, feebly, shallowly imbricate-punctate at middle on basal half, densely, irregularly dentate on apical half, the teeth broad, semierect, variable in size, and rasplike.

Elytra at base subequal in width to pronotum at middle; sides nearly parallel, conjointly broadly rounded at apices (obtusely angulate when viewed from above); surface glabrous on disk, sparsely clothed with very short, inconspicuous hairs on apical declivity, rather finely, densely, irregularly punctate on basal two-thirds; coarsely, deeply punctate, and somewhat rugose on apical declivity; apical declivity with lateral submargins distinctly elevated, united laterally to margins, obtusely rounded on tops, and curving inward to exterior tubercles at anterior margin of declivity, the sutural margins broadly elevated at middle and apex of declivity; each elytron with three long, costiform tubercles along anterior margin of apical declivity, the tubercles obtusely rounded at apices.

Body beneath finely, densely granulose, rather densely clothed with rather short, recumbent, yellowish hairs, the hairs much longer at apex of last visible abdominal sternite, which is broadly rounded at apex.

Female.-Differs from the male in having the tubercles on the front of the head closer together, the pronotum feebly emarginate in front and without an unciform tooth at the apical angles, and the spine at the apex of the anterior tibia larger and more strongly curved.

Length $3.5-6 \mathrm{~mm}$., width $1.4-2 \mathrm{~mm}$.

Type locality.-Of longicornis, Santo Domingo; type in the Paris Museum. Of schwarzi, Capron, Fla., and Santo Domingo; types in the Horn Collection in the Academy of Natural Sciences of Philadelphia. Of rufescens, Brazil; location of type unknown to writer.

Distribution.-This species is distributed throughout South and Central America, Mexico, West Indies, and the southern part of Florida. Large series of speciniens have been examined from all these regions and from the following localities in the United States:

Florida : Biscayne, May 11-29) Caprou, April 25; and Key West, April (lubbard and Schwarz). Paradise Key, February and March (H. S. Barber and T. F. Snyder). Vero Beach, October and November (J. R. Malloch).

Hosts.-Hubbard (1888) recorded the adults as boring into the living trunks and branches of Rhus metopium, but was unable to find larvae in these trees. He found the larvae and adults of this species in the half-burned roots of Smilax. Zetek reports the adults abundant in the pruned and girdled branches of avocada and guayaba in the Canal Zone. Adults have been intercepted at New Tork in derris roots from Ecuador, and at Port Arthur, Tex., in wooden boxes from Cuba. 
Olivier (1795) described Bostrichus Zongicornis collected on dead wood in Santo Domingo by Palisot-Beauvois. Horn (1878) described Tetrapriocera schwarzi from a specimen collected by E. A. Schwarz at Capron, Fla., and another on which he erected his new genus Tetrapriocera, from W. M. Gabb from the Island of Santo Domingo. Gorham (1883) placed schwarzi Horn as a synonym of longicornis Olivier. Dejean (1835) listed A pate rufescens from Brazil without giving any description. Lesne (1901) associated Apate tridens Fabricius (1792) with Tetrapriocera longicomis (1795), placing the latter species as a synonym of tridens. However, after Henriksen examined the type of tridens and found it to be probably the same as the species described by Fabricius (1801) under the name of torquata, Lesne restored longicornis Olivier for this species.

\section{Genus SCOBICIA Lesne}

Scobicia Lesne, 1901, Soc. Ent. de France Ann. (1900) 69: 478-479, 580-600, figs. $423-441$; 1901, Abeille 30 : $87,102-105$, pl. 3, fig. 62 ; Csiki, 1903, Rov. Lapok. 10 : 18, 19 ; Reitter, 1911, Fauna Germanica, Käfer, v. 3, pp. 302, 304; Jakobson, 1913, Käfer Russland, pt. 10, pp. 804, 806 ; Lesne, 1938, in Junk (pub.), Coleopt. Cat., pl. 161, pp. 57-58.

Xylopertha Casey, 1898 (not Guérin-Ménéville 1845), N. Y. Ent. Soc. Jour. 6: $66,67$.

Head deeply inserted in prothorax, not visible from above; clypeus strongly transverse, sinuate in front; labrum transverse, short, truncate and densely ciliate with long, yellowish hairs in front; mandibles more or less attenuate towards apices; eyes small or large, oval, globose, strongly projecting. Antenna short, 9-segmented; first and second segments robust. first elongate, arcuate, flattened on underside, second quadrate or oval, much shorter than first; third to sixth short, transverse, compact, united, shorter than first; last three segments forming a large, loose, compressed club, each with a number of small sensory depressions on each surface, the serenth subtriangular, eighth broadly oblong, and ninth narrowly elongate, narrower and longer than eighth. Pronotum strongly convex, broadly, arcuately emarginate in front, truncate at base, dentate anteriorly, not transversely depressed behind anterior margin, sides not margined. Scutellum small, longer than wide. Elytra strongly convex, with or without tubercles on anterior margin of apical declivity and on thickened sutural margins. Legs short, subequal in length; tibiae expanded toward apices, dentate on exterior margins, each with a large, arcuate spine at apex; posterior tarsi as long as, or longer than, preceding four segments united. Anterior coxae contiguous. Middle coxae narrowly separated. Intercoxal process of abdomen lamellate. Body elongate, cylindrical.

Genotype.-A pate chevrieri Villa. (Present designation.)

Casey (1898) transferred the three American species (suturalis, declivis, and bidentata) from Sinoxylon to Xylopertha Casey (not Xylopertha Guérin-Ménéville). Lesne (1901) erected Scobicia for eight species, five from Europe and three from America, without designating a genotype.

There are scarcely any useful secondary sexual characters for separating the sexes in any of the species of this genus. The females usually have the last visible abdominal sternite a little more deeply emarginate at the apex than the males, and the lateral grooves nearly obsolete. 


\section{Genus XYLOPERTHELLA, New Name}

1. Sutural elevation on apical declivity of elytra armed with distinct, erect teeth

Sutural elevation on apical declivity of elytra unarmed, without erect

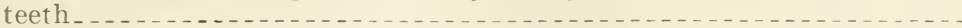

2. Teeth on sutural margins of apical declivity of elytra at middle of declivity ............................... suturalis (Horn), p. 105.

Teeth on or near sutural margins on apical declivity of elytra above middle of declivity -

3. Teeth near sutural margins on apical declivity of elytra large, and distinctly separated at bases.

Teeth on sutural margins on apical declivity of elytra small, and contiguous at bases

4. Tips of elytra obtusely angulated, perpendicularly elevated and angularly separated at sutural margins; apical declivity with a distinct tubercle at lateral margins, and the surface rather densely clothed with long, recumbent hairs........................ lesnei, new species, p. 106.

Tips of elytra conjointly rounded, not perpendicularly elevated at sutural margins; apical declivity with or without a distinct tubercle at lateral margins, and the surface sparsely clothed with short, recumbent hairs .

5. Apical declivity of elytra coarsely punctate, except along sutural margins; sutural stria on each elytron narrowly, deeply depressed and punctate on anterior part of declivity ........... bidentata (Horn), p. 107.

A pical declivity of elytra smooth and vaguely punctate over entire surface: sutural stria on each elytron broad and smooth on anterior part of declivity ............................. monticola, new species, p. 108.

6. Concave surface on apical declivity of elytra sparsely punctate; sutural stria on each elytron shallow and not distinctly punctate near apical declivity of elytra_...................... arizonica Lesne, p. 109.

Concave surface on apical declivity of elvtra not punctate; sutural stria on each elytron deeply depressed and coarsely punctate near apical declivity of elytra_................... declivis (LeConte), p. 110.

7. Apical declivity of elytra obliquely deflexed, margined at sides; tips of elytra not thickened or elevated at sutural margins

chevrieri (Villa), p. 112.

Apical declivity of elytra arcuately deflexed, not margined at sides; tips of elytra thickened and elevated at sutural margins

barbata (Wollaston), p. 113.

\section{Scobicia suturalis (Horn)}

Sinoxylon suturale Horn, 1578, Amer. Phil. Soc. Proc. 17: 542, 544; Coquillett, 1892, Insect Life 4: 261.

Xylopertha suturalis Caser, 1s98, N. Y. Ent. Soc. Jour. 6: 67.

Scobicia suturalis Lesne, 1901, Soc. Ent, de France Ann. (1900) 69 : 586-5sт, 596597, figs. 437-438; 1938, in Junk (pub.), Coleopt. Cat., pt. 161, p. js.

Male.-Dark brown, with basal half of pronotum and elytra, antennae, palpi, femora, and tarsi reddish or yellowish.

Head rather flat, sparsely, finely punctate on front and clypeus, with long, longitudinal, parallel costae on occiput, densely clothed with very long, erect, brownish-yellow hairs. which are shorter and inconspicuous at middle behind clypeus; clypeus flat, slightly depressed at middle along posterior margin; clypeal suture arcuate, and rather distinct at middle, obsolete at sides.

Pronotum slightly wider than long. widest at middle: sides broadly rounded, more strongly converging anteriorly, with a small, broad tooth at apical angles; posterior angles broadly rounded; surface sparsely clothed at sides with long, erect brownish hairs, and on apical half with short, inconspicuous, erect hairs, very finely, sparsely punctate on basal half, more distinctly punctate along sides on apical half and at middle behind anterior margin, densely, irregularly dentate on apical half of disk, the teeth broad, semierect, variable in size, and rasplike. 
Elytra at base subequal in width to pronotum at middle; sides slightly expanded posteriorly, conjointly broadly rounded or obtusely angulated at apices; surface densely clothed with short, recumbent, yellowish hairs, which are shorter and inconspicuous on basal half of disk, densely, finely, shallowly punctate on basal half, sparsely, coarsely, deeply punctate on apical half, impunctate along sutural margins on apical declivity near apices; apical declivity with sutural striae deeply depressed and punctate in front of sutural teeth, the sutural margins narrowly elevated, with two short, contiguous, costiform teeth, one on each margin at middle of declivity, the lateral margins thickened and elevated; each elytron with two or three vague, costiform callosities along lateral margin of apical declivity.

Abdomen beneath densely, finely punctate, densely clothed with short, recumbent, yellowish-white hairs; last visible sternite slightly projecting and subtruncate or vaguely emarginate at apex, with distinct lateral grooves.

Female.-Differs from the male in having the last abdominal sternite shallowly, angularly emarginate at the apex, and the lateral grooves obsolete.

Length 3.4-5 mm., width 1.2-1.6 mm.

Type locality.-Sauzalito, Calif., type in the Horn Collection in the Academy of Natural Sciences of Philadelphia.

Distribution.-From material examined:

California: Los Angeles, March (C. W. Coquillett), July (A. Koebele). Los Gatos (Hubbard and Schwarz). Santa Cruz Mountains (A. Koebele). West Indian Gardens, Altadena.

Hosts.-Coquillett (1892) recorded the adults of this species burrowing in dead grape vines during October, usually two adults at each joint.

Horn described this species from a single specimen collected by James Behrens.

Scobicia lesnei, new species

Scobicia bidentata Lesne (not Horn), 1901, Soc. Ent. de France Ann. (1900) 69 : 587, 599-600, fig. 441.

Female.-Dark brown, base of pronotum rarely reddish, elytra reddish brown, paler toward base, antennae, palpi, femora in part, and tarsi yellowish brówn.

Head slightly convex, finely, rather densely punctate on front and clypeus, with fine, longitudinal, parallel costae on occiput, rather densely clothed on front with very long, erect, brownish hairs, which are shorter and inconspicuous at middle behind clypeus; clypeus flat, slightly depressed at middle along posterior margin; clypeal suture depressed at middle, obsolete at sides.

Pronotum slightly wider than long, widest at middle; sides regularly, broadly rounded, with a small, broad tooth at apical angles; posterior angles broadly rounded; surface sparsely clothed with short, recumbent and erect, inconspicuous hairs, with numerous very long, erect, brownish hairs along sides on apical half and along anterior margin, very sparsely, finely punctate on basal half, coarsely, sparsely dentate at middle along anterior margin, densely, irregularly dentate on apical half, the teeth broad, semierect, variable in size, and rasplike.

Elytra at base subequal in width to pronotum at middle; sides 
slightly expanded posteriorly, obtusely angulated at apices, which are angularly separated; surface densely clothed with rather long, recumbent whitish hairs posteriorly, the hairs short and inconspicuous on basal half of disk, coarsely, densely punctate, the punctures shallow on basal half, becoming coarser and deeper on apical declivity, but impunctate along sutural margins behind teeth on declivity; apical declivity with sutural striae deeply depressed on anterior part, the sutural margins not strongly elevated but broadly expanded above middle of declivity and armed with two small teeth, which are acute at apices, slightly divergent, and separated at bases, the lateral margins thickened and elevated into an erect, obtuse tubercle near sutural angle; each elytron with a rather acute, semierect tubercle at middle along lateral margin of apical declivity.

Abdomen beneath rather coarsely, densely punctate, rather densely clothed with moderately long, recumbent, whitish hairs; last visible sternite triangularly emarginate at apex, with indistinct lateral grooves and lateral pieces.

Male.-Differs from the female in having the last visible abdominal sternite rounded at the apex, and with distinct lateral grooves and lateral pieces.

Length $3.5-5.5 \mathrm{~mm}$., width $1.2-2 \mathrm{~mm}$.

Type locality.-Texas, no definite locality.

Type. allotype, and paratypes.-In the United States National Museum, No. 58316.

Described from five specimens (one female type). The type was collected by G. W. Belfrage; the allotype was collected on elm at Uvalde, Tex., by W. F. Fiske; one paratype labeled Texas, collected by Mr. Fuller; one paratype collected March 15 at Cypress Mills, Tex.; and one paratype from Texas, reared February 2, 1893, from fig twigs.

\section{Scobicia bidentata (Horn)}

Sinoxylon bidentatum Horn, 1878, Amer. Phil. Soc. Proc. 17 : 542, 544.

Xylopertha bidentata Casey, 1898, N. Y. Ent. Soc. Jour. $6: 67$.

Scobicia bidentata Leonard, 1928, N. Y. (Cornell) Agr. Expt. Sta. Mem. 101: 415; Lesne, 1938, in Junk (pub.), Coleopt. Cat., pt. 161, p. 57 ; Brimley, 1938, Insects of North Carolina, p. 197; Anderson, 1939, Wash. Acad. Sci. Jour. 29 (9) : 391 , figs. 36, 42 (larvae).

Male.-Dark brown, base of pronotum reddish, elytra usually reddish brown, sometimes yellowish toward base; palpi, femora, and tarsi yellowish brown.

Head slightly convex, finely, densely punctate on front and clypeus, with longitudinal, parallel costae on occiput, rather densely clothed on front with very long, erect, brownish hairs, which are shorter at middle behind clypeus; clypeus flat, slightly depressed at middle along posterior margin ; clypeal suture depressed at middle, obsolete at sides.

Pronotum slightly wider than long, widest behind middle; sides broadly rounded, more strongly converging anteriorly, with a small. broad tooth at apical angles; posterior angles broadly rounded; surface sparsely clothed with short, erect and recumbent, inconspicuous hairs, with numerous very long, erect, whitish hairs along sides on apical half, finely, very sparsely punctate on basal half, sparsely, coarsely punctate at sides on apical half and at middle along anterior margin, densely, irregularly dentate on apical half of disk, the teeth broad, semierect, variable in size, and rasplike. 
Elytra at base subequal in width to pronotum behind middle; sides vaguely expanded posteriorly, separately obtusely rounded at apices; surface sparsely clothed with short, recumbent, yellowish-white hairs, densely, coarsely punctate, the punctures coarser and deeper on apical declivity, but impunctate along sutural margins behind marginal teeth on declivity; apical declivity with sutural striae deeply depressed in front of teeth on declivity, the sutural margins broadly expanded and elevated, with two large, round teeth near top of declivity, the teeth slightly divergent and separated at bases, and the lateral margins thickened and strongly elevated; each elytron with two more or less distinct, castiform callosities along lateral margin of apical declivity.

Abdomen beneath densely, finely punctate, rather densely clothed with short, recumbent, yellowish hairs; last visible sternite subtruncate at apex, with distinct lateral grooves.

Female.-Differs from the male in having the last visible abdominal sternite vaguely emarginate at the apex, and the lateral grooves obsolete.

Length 3-5 mm., width 1-1.6 mm.

Type Tocality.-Nebraska, no definite locality; type in the Horn Collection in the Academy of Natural Sciences of Philadelphia.

Distribution.-From material examined:

District of Columbia : Washington, June 13-27 (Hubbard and Schwarz). Rock

Creek Park and Brookland (R. W. Van Horn).

Georgia : Barnesville, May 29, 1933 (T. L. Bissell).

Illinors : Southern part (H. Soltau).

IndANA : Hammond, May 30, 1915 (C. Selinger).

Kansas : Riley County (E. A. Popenoe).

Maryland: Bladensburg, June 13, 1916.

MuCHgaN : Detroit, June (Hubbard and Schwarz).

Nebraska: No locality (Hubbard and Schwarz).

New Jersey : Camden (G. M. Greene). Clementon (H. A. Kaeber).

New York: West Point, June 22, 1913 (W. Robinson). Long Island (M. L. Linell).

VIrainia: Rosslyn (F. H. Chittenden).

Hosts.-The species has been reared from hickory (Hicoria sp.) and chestnut (Castanea dentata (Marshall) Borkhausen).

Horn described this species from a single specimen. Lesne (1901) redescribed what he thought to be this species from a single female collected in Texas by Belfrage. This last specimen is not bidentata Horn, but lesnei Fisher.

\section{Scobicia monticola, new species}

Male.-Brownish black, base of pronotum reddish on each side, antennae and legs, except tarsi, reddish brown, palpi and tarsi brownish yellow.

Head slightly convex, sparsely, rather finely punctate on front and clypeus, with fine, longitudinal, parallel costae on occiput, rather densely clothed on front with very long, erect, yellowish-white hairs, which are shorter and inconspicuous at middle behind clypeus; clypeus flat, deeply depressed at middle along posterior margin; clypeal suture distinct at middle, obsolete at sides.

Pronotum slightly wider than long, widest behind middle; sides broadly rounded, more strongly converging anteriorly, with three small, broad teeth on each side near apical angle; posterior angles 
broadly rounded: surface sparsely clothed with short, inconspicuous hairs, which are recumbent on basal half and erect on apical half, and with numerous very long, erect. vellowish white hairs along sides and anterior margin, finely, sparsely, indistinctly punctate on basal third, densely, coarsely punctate or rugose at middle along anterior margin, densely, irregularly dentate on apical half, the teeth broad. semierect, rariable in size, and rasplike.

Elrtra at base slightly narrower than pronotum at middle; sides slightly expanded posteriorly, conjointly broadly rounded at apices; surface sparsely clothed with short, recumbent, reddish-brown hairs. which are slightly longer on apical declivity, densely, coarsely, deeply punctate on disk, finely, sparsely, indistinctly punctate on apical declivity: apical declivity with sutural striae smooth and not depressed on anterior part, the sutural margins narrowly elevated, armed near top of declivity with two short, conical teeth, which are obtusely rounded at apices and separated at bases, the lateral margins thickened and strongly elerated, but without elevated tubercles at sutural angles; each elytron with a moderately elerated, obtuse tubercle behind middle along lateral margin of apical declivity.

Abdomen beneath sparsely, rather finely, shallowly punctate, sparsely clothed with short, recumbent, whitish hairs; last visible sternite rounded at apex, with distinct lateral grooves and lateral pieces.

Female.-Unknown.

Length $5.5 \mathrm{~mm}$., width $1.8 \mathrm{~mm}$.

Type locality.-Santa Catalina Mountains, Ariz.

Type.-In the United States National Museum, No. 58317.

Described from a single male specimen reared June 14, 1915, from white oak (Quercus alba Linn.) collected at the type locality by M. Chrisman. There is also a broken specimen in the collection reared August 13, 1914, from oak (Quercus sp.) collected at the same locality by II. Chrisman.

\section{Scobicia ARIZoNica Lesne}

Scobicia arizonica Lesne, 1907, Paris Mus. d'Hist. Nat. Bul., pp. 244-245; 1935, in Junk (pub.), Coleopt. Cat., pt. 161, p. $5 \bar{\tau}$.

Male-Dark reddish brown to brownish black, usually with base of pronotum reddish ; antennae, palpi, and legs (except sometimes tibiae) brownish yellow.

Head slightly conrex, sparsely, finely punctate on front and clypeus. with fine, longitudinal, parallel costae on occiput, rather densely clothed on front with very long, erect. brownish hairs, which are short and inconspicuous at middle behind clypeus; clypeus flat. slightly depressed at middle along posterior margin. sometimes longitudinally groored at middle, with or without a small tooth on each side along anterior margin at base of labrum; clypeal suture sinuate, depressed at middle. distinct at sides.

Pronotum slightly wider than long, widest at middle: sides broadly rounded, more strongly conrerging anteriorly with a small, broad tooth at apical angles; posterior angles broadly rounded; surface sparsely clothed with short, inconspicuous hairs, which are recumbent on basal half and erect on apical half. with numerous long, erect. brownish hairs along sides and anterior margin, finely, sparsely punctate or granulose on basal half, except near posterior angles, where the surface 
is impunctate, densely, finely punctate or granulose at middle along anterior margin, densely, irregularly dentate on apical half, the teeth broad, semierect, variable in size, and rasplike.

Elytra at base subequal in width to pronotum at middle; sides parallel, conjointly broadly rounded at apices; surface sparsely clothed with short, recumbent, inconspicuous hairs, coarsely, densely punctate, extept on apical declivity, where the surface is longitudinally concave and very sparsely, finely punctate; apical declivity with sutural striae smooth and not depressed on anterior part, the sutural margins narrowly elevated, not expanded laterally, armed at top of declivity with two small teeth, which are obtuse at apices and contiguous at bases, the lateral margins thickened and strongly elevated; each elytron with two or three smooth, obtusely rounded costae at base.

Abdomen beneath sparsely, finely punctate, sparsely clothed with short, recumbent, yellowish-white hairs; last visible sternite rounded at apex, with the lateral grooves distinct.

Female.-Differs from the male in having the last visible abdominal sternite slightly, angularly emarginate at the apex, and the lateral grooves obsolete.

Length 3-6 mm., width 1-2 mm.

Type locality.-Arizona, no definite locality; types in the Paris Museum and the Pic Collection.

Distribution.-From material examined:

ArIzona: Chiricahua Mountains, June 16, and Santa Rita Mountains, May 26 (Hubbard and Schwarz). Palmerlee, Cochise County, July (C. Schaeffer). Santa Catalina Mountains (J. L. Webb and M. Chrisman). Redington, April 7 , 1913 (M. Chrisman). Prescott National Forest, June 16, 1930 (M. W. Black$\operatorname{man})$.

Texas: Uralde (W. F. Fiske). Cypress Mill, March 15 (F. H. Chittenden).

Hosts.-This species has been reared from Emory oak (Quercus emoryi Torrey), Arizona white oak (Quercus arizonica Sargent), canyon live oak (Quercus chrysolepis Liebmann), walnut (Juglans sp.), elm (Ulmus sp.), and hackberry (Celtis sp.).

Lesne described this species from two specimens (male and female) from Arizona without giving any definite locality:

\section{Scobicia declivis (LeConte)}

Sinoxylon declive LeConte, 1857, Explorations and Survey, Pacific R. R. Rpt. 12 (2) : 19, 48; Horn, 1878, Amer. Phil. Soc. Proc. 17 : 542, 544; Comstock, 1881, U. S. Dept. Agr., Ent. Rpt. for 1850 , p. 275 ; Rivers, 18s6, Calif. Acad. Sci. Bul. 2 : 63-72; Coquillett, 1892, Insect Life 4 : 260-261; Wickham, 1895, Iowa Univ. Lah. Nat. Hist. Bul. 3: 33-34, pl. 1, fig. 2 (larva) ; Fall, 1901, Calif. Acad. Sci. Occas. Papers 8: 2S2; Baker, 1915, Engin. News 74: 1006 ; Schuler, 1916, Telephony $70: 17-19,24-25$, figs.

Xylopertha declivis Casey, 189S, N. Y. Ent. Soc. Jour. 6: 67; Essig, 1915, Injurious and Beneficial Insects of California, ed. 2, p. 239.

Scobicia declivis Lesne, 1901. Soc. Ent. de France Ann. (1900) 69: 587, 597-59s, figs. 439-440; anonymous, 1919, Field and Farm 34:10; Snyder, 1920, Wash. Acad. Sci. Jour. 10: 580; Child, 1920, Sci. Amer. 123: 637, fig. 1; Böving, 1922, U. S. Dept. Agr. Bul. 1107, app. 49-54, pls. 1-2 (larvae) ; Burke, Hartman, and Snyder, 1922, U. S. Dept. Agr. Bul. 1107, pp. 1-48, figs. 3-15, pls, 3-10; Böving and Craighead, 1931, Ent. Amer. (n. s.) 11: pl. 101, figs. O-W, Y-Z (figures larva) ; Lesne, 1938, in Junk (pub.), Coleopt. Cat., pt. 161, p. 58; Anderson, 1939, Wash. Acad. Sci. Jour. 29 (9) : 391, figs. 37-38 (larvae).

Male.-Brownish black, with the posterior angles of pronotum, humeri, antennae, palpi, legs, and abdomen in part reddish or yellowish brown. 
Head moderately convex, sparsely, finely punctate on front and clypeus, with fine, longitudinal, parallel costae on occiput, rather densely clothed on front with very long, erect, brownish hairs, which are short and inconspicuous at middle behind clypeus; clypeal suture distinct at middle, obsolete at sides.

Pronotum slightly wider than long, widest at middle; sides broadly rounded or parallel posteriorly, arcuately converging anteriorly, with a small, broad tooth at anterior angles; posterior angles broadly rounded; surface rather densely clothed along sides and anterior margin with long, erect, brownish-yellow hairs, very sparsely, finely punctate at sides on basal half and at middle along anterior margin, obsoletely, imbricate-punctate or granulose at middle on basal half, densely, irregularly dentate on apical half, the teeth broad, semierect, variable in size, and rasplike.

Elytra at base subequal in width to pronotum at middle; sides nearly parallel, conjointly broadly rounded at apices; surface sparsely clothed with very short, recumbent, inconspicuous, yellowish hairs, coarsely, densely, deeply punctate, except along sutural margins on apical declivity, where the surface is impunctate and smooth; apical declivity with sutural striae deeply depressed on anterior part, the sutural margins slightly, narrowly elevated, with two short, contiguous teeth, one on each margin near top of declivity, lateral margins thickened and elevated; each elytron with two smooth, obtusely rounded costae at base.

Abdomen beneath densely, finely punctate, sparsely clothed with short, recumbent, yellowish hairs; last visible sternite rounded at apex with the lateral grooves distinct.

Female.-Resembles the male very closely, but usually has the last visible abdominal sternite slightly emarginate at the apex and the lateral pieces obsolete.

Length 5-7.5 mm., width $1.75-2.75 \mathrm{~mm}$.

Type locality.-Sacramento, Calif.; type in the LeConte Collection in the Museum of Comparative Zoology, Cambridge, Mass.

Distribution.-From material examined:

California: Los Gatos, Santa Cruz Mountains, Fresno, Monterey, Yosemite Valley, King's River, Inyo Mountains, Kaweah, Sylvania, Lake Tahoe, Confidence, Hillsborough, Argus Mountaius, Hollister, Lamoine, Los Angeles, Mokelumne, Dunsmuir, Nordhoff, Palo Alto, Shingle Springs, Placerville, Salinas, San José, Vade, Watsonville, Sacramento, Tuolumne, Pomona, Orange, Cisco, Fort Tejon, Sonoma, Afton Canyon, Merced Falls, Humboldt County, and San Nicolas Island.

Oregon: Hood River, Corvallis, Ashland, and Benton County.

WASIIINGTON : Yakima.

Hosts.-Adults have been reared from sweet cherry (Prumus avium L.), coast live oak (Quercus agrifoliá Née), California black oak (Quercus kelloggii Newberry), California blue oak (Quercus douglasii Hooker and Arnott), valley white oak (Quercus lobata Née), canyon live oak (Quercus chrysolepis Liebmann), tan oak (Quercus densiflora (Hooker and Arnott) Rehder), English elm (Ulmus campestris L.), bigleaf maple (Acer macrophyllum Pursh.), Oregon myrtle ( $C m$ bellularia california (Hooker and Arnott) Nuttall.), gum (Eucalyptus sp.) and wattle (Acacia sp.). Coquillett (1892) recorded it from orange and rose stalks. E. J. Newcomer reared it from grape canes at Yakima, Wash. 
In the economic literature this beeetle is listed under the common name "lead cable borer." This species causes considerable damage to the lead sheathing of aerial cables by boring round holes through the lead sheathing from the outside surface to the paper insulation of the wires within, causing the electric current to be short-circuited. In many cases this injury is not noticed until after a rain, when the water soaks through and causes the short circuit. In some cases these beetles may attack and kill living trees. Rivers (1886) recorded the adults of this species attacking dry lumber, particularly oak, and especially oaken wine casks, causing serious loss to the wine industry. A detailed account of the biology of this species is given by Böving (1922).

\section{Scobicia Chevrieri (Villa)}

Apate cherrieri Villa, 1835, Coleopt. Europae dupleta Sup., p. 49 (publication not seen.)

Xylopertha chevrieri Jacquelin-Duval, 1859-1863, Genera Coléopt. Europe, v. 3, Cat. p. 167; Lesne, 1900, Soc. Ent. de France Bul., pp. 10-12.

Scobicia chevrieri Lesne, 1901, Soc Ent. de France Ann. (1900) 69: 568, 592-595, figs. $260,423,425,433,435 ; 1901$, Abeille $30: 103,104-105$, pl. 3, figs. 61-62. $70-72 ; 1902$, ibid. 30 : 125, Csiki 1903, Rov. Lapok. 10: 19; Lesne, 1904, Abeille 30: 1.57; Reitter, 1911, Fauna Germanica, Käfer, v. 3, p. 304; Lesne, 1938, in Junk (pub.), Coleopt. Cat., pt. 161, pp. 57-58.

Apate capillata Dejean, 1836, Cat. Coleopt., ed 3 rev., p. 334.

Xylopertha foveicollis Allard, 1869, Abeille 5: 468; Waterhouse, 1858, Ann. and Mag. Nat. Hist. (ser. 6) 1:249.

Xylopertha pustulata Kiesenwetter (not Fabricius), 1877, in Erichson, Naturgesch. Insect. Deut. Coleopt., v. 5, pt. 1, pp. 38-39; Zoufal, 1894, Wien. Ent. Ztg. 13: 39 (part) ; Lesne, 1896, Soc. Ent. de France Ann. 65: pl. 8, fig. 4; Schilsky, 1899 , in Küster and Kraatz, Käfer Europas 36 (93).

Scobicia pustulata Jakobson, 1913, Käfer Russland, pt. 10, p. S06, pl. 43, fig. 9 ; Lesne, 1937, Soc. Ent. de France Bul. 42 : 239.

The bibliography given for this species is not complete, as only the more important articles are cited.

Male.-Dark brown, usually with basal area of pronotum and elytra reddish ; antennae, palpi, and legs (except sometimes tibiae) brownish yellow.

Head flat, and finely, rather densely punctate on front, convex, with fine, longitudinal, parallel costae on occiput, rather densely clothed on front with very long, erect, brownish-yellow hairs, which are shorter and inconspicuous on median part behind clypeus; clypeus slightly convex, constricted and longitudinally grooved at middle, rather densely, shallowly punctate; clypeal suture distinct, sinuate; eyes large.

Pronotum wider than long, widest behind middle; sides broadly rounded, more strongly converging anteriorly, with a small, broad tooth at apical angles; posterior angles broadly rounded; surface sparsely clothed with short, recumbent, inconspicuous hairs, smooth and impunctate on basal half, sparsely, finely punctate or granulose at middle along anterior margin, rather densely, irregularly dentate on apical half, the teeth broad, semierect, variable in size, and rasplike.

Elytra at base narrower than pronotum behind middle; sides slightly expanded posteriorly, conjointly broadly rounded (obtusely angulate when viewed from above) at apices; surface sparsely clothed with recumbent, brownish-yellow hairs, which are very short and inconspicuous on disk, but longer and denser on apical declivity, finely, densely punctate on disk, very coarsely, deeply punctate on apical 
declivity; apical declivity obliquely deflexed, the margins at sides distinct and slightly gibbose posteriorly, with sutural striae depressed and punctuate on anterior part: the sutural margins strongly gibbose and expanded below middle of declivity, the margins not tuberculate but the sides perpendicular, lateral margins not thickened or elevated.

Abdomen beneath finely, shallowly punctate or granulose, sparsely clothed with short, recumbent, whitish hairs; last visible sternite rounded at apex, with rather distinct lateral grooves.

Female.-Differs from the male in having the last visible abdominal sternite angularly emarginate at the apex, and with the lateral grooves obsolete.

Length $2.25-4.5 \mathrm{~mm}$., width $1-1.5 \mathrm{~mm}$.

Type locality.-Of chevrieri, unknown to writer. Of foveicollis, Sicily; type probably in the René Oberthür Collection. Of pustulata, southern Tyrol; type was in the München Museum. Of capillata, Lombardy, Italy; location of type unknown to writer.

Distribution.-This species is widely distributed throughout the Mediterranean region, both in southern Europe and northern Africa. Adults were intercepted at New York, July 18, 1927, in roots from Italy, and also were reared from hardwood strips binding bales of cork received from the Mediterranean region, and stacked along the railroad at Nicholson, Miss. So far as known, this species has not become established in the United States.

Hosts.-This species is recorded in the literature as attacking the following plants: fig (Ficus sp.), mulberry (Morus sp.), green oak (Quercus ilex L.), laurel, mastic tree (Pistacia lentiscus L.), English oak (Quercus robur L.), evergreen oak (Quercus coccifera L.), birch (Betula sp.), fox grape (Vitis labrusca L.), and pomegranate (Punica gramatum L.).

\section{Scobicia barbata (Wollaston)}

Enneadesmus barbatus Wollaston, 1860, Ann. and Mag. Nat. Hist., (ser. 3), 5: $359-360$.

Xylopertha barbata Wollaston, 1865, Coleopt. Atlantidum, p. 231, app., pp. 38-39. Scobicia barbata Lesne, 1901, Soc. Ent. de France Ann. (1900) 69: 586, 591, figs. 428, 430; 1901, Abeille $30: 102$, 104, pl. 3, figs. 67-68, 1938, in Junk (pub.), Coleopt. Cat. pt. 161, p. 57.

Female.-Dark reddish brown, basal area of pronotum and elytra. antennae, palpi, and legs paler.

Head flat, and finely, densely punctate on front, convex, with long, longtitudinal, parallel costae on occiput, rather densely clothed with very long, erect, brownish-yellow hairs, which are shorter at middle in front of clypeus; clypeus flat, depressed at middle along posterior margin, densely, finely punctate or granulose; clypeal suture sinuate, obsolete toward sides; eyes large.

Pronotum slightly wider than long, widest at basal third; sides broadly rounded posteriorly, strongly converging anteriorly, with a small, broad, arcuate tooth at apical angles; posterior angles broadly rounded; surface sparsely clothed with short, recumbent, inconspicuous hairs, with a few long, erect, yellowish hairs along sides anteriorly, very sparsely, finely punctate on basal half, finely, densely granulose at middle along anterior margin, densely, irregularly dentate on apical half, the teeth broad, semierect, variable in size, and rasplike.

$842409-50-8$ 
Elytra at base subequal in width to pronotum at basal third; sides slightly expanded posteriorly, conjointly broadly rounded (obtusely angulate when viewed from above) at apices; surface rather densely clothed posteriorly with short, recumbent, yellowish hairs. which are sparser and inconspicuous on basal half, sparsely, rather finely, shallowly punctate on basal half, coarsely, densely, deeply punctate on apical half; apical declivity arcuately deflexed, the margins at sides of declivity obsolete, but with one or two obsolete callosities on each side, with sutural striae deeply depressed and punctured on anterior part of declivity, the sutural margins strongly gibbose and broadly expanded at middle of declivity, the sides of gibbosity perpendicular, but the margins not tuberculate, lateral margins slightly thickened and elevated at sutural angles.

Abdomen beneath coarsely, densely punctate, sparsely clothed with short, recumbent, yellowish-white hairs; last visible sternite emarginate at apex, with obsolete lateral grooves.

Male.-Not seen.

Length $5 \mathrm{~mm}$., width $1.6 \mathrm{~mm}$.

Type of locality.-Quinto de São João, near Funchal, Madeira Islands; type in the Hope Museum at Oxford.

Distribution.-This species is recorded in the literature from Porto Santo, Praia Formosa, and Quinta de São João, all in the Madeira Islands. One specimen was intercepted at Boston, December 7, 1925, with tomato seeds from the Azores Islands. So far as known, it has not become established in the United States.

Hosts.-Nothing is recorded about the biology of this species except that Bewicke collected several adults among old $\log \mathrm{s}$ of wood in a small shed or outhouse.

\section{Genus OCTODESMUS Lesne}

Octodesmus Lesne, 1901, Soc. Ent. de France Ann. (1900) 69:479, 616-620; 1938, in Junk (pub.), Coleopt. Cat., pt. 161, p. 61.

Head deeply inserted in prothorax, not visible from above; clypeus strongly transverse, emarginate or lobed in front; labrum transverse, broadly rounded and densely ciliate with long, white hairs in front; mandibles attenuate toward apices; eyes oval, globose, strongly projecting. Antenna 8-segmented; first and second segments robust, first elongate, twice as long as second, which is oval; third to fifth segments short, compact, transverse, united subequal in length to second; last three segments forming a large, loose, compressed club, densely clothed with short, recumbent yellow hairs, each with two round sensory depressions on each surface, the sixth segment subtriangular, seventh oval, and eighth elongate oval, narrower and longer than seventh. Pronotum strongly convex, truncate at base and apex, dentate anteriorly, not transversely depressed behind anterior margin; sides not margined. Scutellum small, transverse. Elytra strongly convex, with distinct tubercles on anterior margin of apical declivity. Legs short, subequal in length; tibiae strongly expanded toward apices, dentate on exterior margins, each with a large, arcuate spine at apex; posterior tarsi as long as, or longer than tibiae, apical segment of each shorter than preceding four segments united. Anterior coxae contiguous. Middle coxae narrowly separated. Intercoxal process of abdomen lamellate. Body elongate, cylindrical. 
Genotype.-Octodesmus episternalis Lesne. (Present designation.)

Lesne (1901) erected Octodesmus for 2 species, Xylopertha parvulus Lesne and Octodesmus episternalis Lesne, both from India, the former described from a single female and the latter from 11 examples including both sexes. No genotype was designated by Lesne.

\section{Octodesmius episternalis Lesne}

Octodesmus episternalis Lesne, 1901, Soc. Ent. de France Ann. (1900) 69: 617, 618-620, figs. 470-472; 1938, in Junk (pub.), Coleopt. Cat., pt. 161, p. 61.

Male.-Brownish yellow, with pronotum and apical declivity of elytra reddish, the head and anterior tibiae dark reddish brown.

Head slightly convex, vaguely, transversely concave behind eyes, glabrous, densely, finely granulose on front, with fine, longitudinal, parallel costae on occiput; clypeus slightly convex, coarsely densely punctate or rugose, deeply depressed at middle along posterior margin, the anterior margin with a short, median lobe, which is subtruncate at apex; clypeal suture feebly indicated at middle.

Pronotum subequal in length and width, widest behind middle; sides broadly, strongly rounded, more strongly converging anteriorly, with a small broad tooth near apical angles; posterior angles broadly rounded; surface glabrous posteriorly with numerous long, erect hairs along lateral margins on apical half; smooth and indistinctly punctate on basal half, rather densely, irregularly dentate on apical half, the teeth broad, semierect, variable in size, and rasplike.

Elytra at base subequal in width to pronotum behind middle; sides nearly parallel, sinuate, thickened, and strongly elevated along apical declivity, triangularly separated at sutural margins; surface glabrous, finely, densely punctate on basal two-thirds, impunctate and indistinctly granulose on apical declivity; apical declivity abruptly, obliquely deflexed, concave, the sutural margins strongly, narrowly elevated, and sparsely punctate on tops; each elytron with a long, acute, slightly arcuate spine at middle along exterior margin of apical declivity.

Abdomen beneath indistinctly punctate, sparsely clothed with short, recumbent, inconspicuous hairs; last visible sternite broadly rounded at apex. Metasternal episternum very large, convex, arcuate on inner margin. Anterior tibiae strongly expanded at apices, feebly, longitudinally concave on inner surface; anterior and posterior tibiae clothed with long, white hairs.

Femate.-Differs from the male in having the lateral margins of the elytra dentate on the underside near the sutural angles, the last visible abdominal sternite deeply emarginate at the apex, and the preceding sternite armed with two very fine spines at the middle of the posterior margin.

Length 4-5.5 mm., width 1.4-1.7 mm.

Type locality.- "Carin Cheba and Asciuii Cheba." altitude 900 to 1,300 meters, Burma; and northern India. 'Types in the Genoa and Paris Museums and the Oberthür Collection.

Distribution. - This species has been recorded only from the trpe localities. Two specimens were intercepted at Boston, Mass., August 9, 1916, in bamboo from Maymyo, Burma. So far as known, it has not become established in the United States.

Hosts.-Nothing has been recorded on the habits of this species. 
This is the only species- of Bostrichidae having the inner margin of the metasternal episternum arcuate.

\section{Genus XYLOPERTHELLA, New Name}

Xylopertha Lesne, 1901, Soc. Ent. de France Ann. (1900) 69:477, 527-536; 1901, Abeille 30: 87, 97-99, pl. 2, figs. 45, 46; Jakobson, 1913, Käfer Russland, pt. 10, pp. 804, 806 (part) ; Lesne, 1924, Bostrychides de l'Afrique Tropicale Francaise, pp. 209, 217-226; 1938, in Junk (pub.), Coleopt. Cat., pt. 161, pp. 62-63.

Head deeply inserted in prothorax, not visible from above; clypeus strongly transverse, shallowly, arcuately emarginate in front, obtusely angulated on each side at lateral margin of labrum; labrum large, transverse, broadly rounded or subtruncate, and densely ciliate with long golden-yellow hairs in front; mandibles attenuate toward apices; eyes oval, globose, strongly projecting. Antenna 10-segmented; first and second segments robust, first elongate, twice as long as second, which is oval; third to seventh segments short, compact, transverse (except third), united subequal in length to first segment of club; last three segments forming a large, loose, compressed club, densely clothed with short, recumbent, yellowish hairs, but without distinct sensory depressions, eighth and ninth subtriangular, slightly transverse, and tenth oval, slightly longer than ninth. Pronotum slightly convex, arcuately emarginate in front, truncate at base, dentate anteriorly, not transversely depressed behind anterior margin; sides not margined. Scutellum small, quadrate. Elytra strongly convex, with or without tubercles on anterior margin of apical declivity. Legs rather long, subequal in length; tibiae expanded toward apices, each with a large, arcuate spine at apex, dentate on exterior margins; posterior tarsi as long as, or longer than tibiae, apical segment of each shorter than preceding four segments united. Anterior coxae contiguous. Middle coxae narrowly separated. Intercoxal process of abdomen lamellate. Body elongate, cylindrical.

Genotype.-Bostrichus piceus Olivier. (Present designation.)

Lesne (1901) restricted the use of Xylopertha for three species, crinitarsis Imhoff, picea Olivier, and scutula new species, all from Africa. None of these species were originally included in Xylopertha, and he probably overlooked the designation of sinuata Fabricius as the type of Xylopertha by Gorham. ${ }^{9}$ Since Xylopertha cannot be used for the above species, I propose Xyloperthella for Xylopertha Lesne (1901), not Xylopertha Guérin-Ménéville (1845).

\section{Xyloperthella CRINitarsis (Imhoff)}

Tylopertha (?) crinitarsis Imhoff, 1843, Verh. Naturf. Ges. Basel 5: 177 (publication not seen).

Xylopertha crinitarsis Lesne, 1901, Soc. Ent. de France Ann. (1900) 69: 528, 534-535, figs. 330, 332; 1924, Bostrychides de l'Afrique Tropicale Française, pp. 219, 225-226, figs. 5, 24, 136, 144, 145; 1938, in Junk (pub.), Coleopt. Cat., pt. 161, p. 62.

Sinoxylon pubescens MIurray, 1867, Ann. and Mag. Nat. Hist. (ser. 3) 20 : 93-94. Xylopertha pubescens Lesne, 1896, Soc. Ent. de France Bul., p. 335.

Male.-Dark reddish brown, with bases of elytra and pronotum slightly paler, sometimes entirely reddish brown, the antenna and palpi yellowish brown.

${ }^{9}$ Gorham, H. S. Malacodermata. Biol. Centr.-Amer., Coleopt., v. 3, pt. 2, p. 215, 1833. 
Head slightly convex: front slightly deflexed along anterior margin, densely, finely granulose, sparsely clothed with short, recumbent, whitish hairs; occiput with fine, longitudinal, parallel costae; clypeus flat, coarsely, sparsely punctate, sparsely clothed with short, semierect, inconspicuous hairs; clypeal suture deeply depressed at middle, indistinct toward sides.

Pronotum distinctly wider than long, widest at basal third; sides broadly rounded posteriorly, more obliquely coverging anteriorly, with a large, broad, unciform tooth at apical angles; posterior angles broadly rounded; surface sparsely clothed with short. recumbent and semierect, inconspicuous hairs, sparsely, rather finely granulose on basal half, densely, irregularly dentate on apical half, the teeth broad, semierect, variable in size, and rasplike, with a few larger teeth on each side near lateral margins.

Elytra at base subequal in width to pronotum at basal third; sides slightly expanded posteriorly, conjointly triangularly emarginate at apices (obtusely angulate when viewed from above); surface rather densely clothed with very short, recumbent. yellowish hairs, which are more semierect on apical declivity, finely, densely punctate on basal two-thirds, the punctures denser and coarser posteriorly, coarsely, deeply, confluently punctate on apical declivity; sutural margins broadly expanded and moderately elevated on apical declivity, strongly. abruptly elevated at apices; lateral submargin extending inward to near lateral tubercle on anterior margin of apical declivity; each elytron with three distinct, costiform tubercles along anterior margin of apical declivity, the two sutural tubercles spinose at apices, the lateral one obtusely rounded at apex.

Abdomen beneath finely, densely punctate, densely clothed with short, recumbent, yellowish hairs; last visible sternite broadly rounded at apex.

Female--Differs from the male in haring the underside of the lateral margins of the elytra armed with a large, broad tubercle near the sutural angles, and the last visible abdominal sternite with a large, round emargination at the apex, the emargination nearly closed posteriorly by two converging spiniform teeth.

Length $5.5-9 \mathrm{~mm}$.. width $2.75-3.4 \mathrm{~mm}$.

Type locality.-Of crinitarsis, Africa (?); location of type unknown to writer but probably in the Museum at Basel, Switzerland. Of pubescens, Old Calabar, Africa; type in the British Museum.

Distribution.-The distribution of this species is restricted to the central-western part of Africa, from Portuguese Guinea to Loanda, and includes French Guinea. Sierra Leone, Liberia, Irory Coast, Gold Coast, Nigeria, Kamerun. Togoland, Portuguese Guinea, and Belgian Congo. This species has been intercepted at New York and Baltimore in mahogany logs from the Gold Coast, Africa. So far as known, it has not become established in the United States.

Hosts.-Lesne (1924) records this species as living in the dead wood of Cacaoyer (cacao tree).

\section{Genus XYLOPRISTA Lesne}

Xyloprista Lesne, 1901, Soc. Ent. de France Ann. (1900) 69 : 475. 497-502; 193 s. in Junk (pub.), Coleopt. Cat., pt. 161, p. 55.

Head deeply inserted in prothorax, not visible from above; clypeus strongly transverse, subtruncate in front, with a small tooth on each 
side at base of labrum; labrum short, transverse, densely ciliate in front with long, yellow hairs; mandibles simple in both sexes, attenuate toward apices; eyes large, oval, globose, strongly projecting. Antenna short, 10-segmented, densely clothed with long hairs; first and second segments robust, elongate, the first arcuate and much longer than second; third to seventh segments small, transverse, compact, united shorter than first; last three segments forming a large, loose club, with numerous small, round, sensory depressions on each surface, the eighth and ninth segments irregularly oblong, and tenth narrowly elongate, longer than ninth. Pronotum strongly convex, emarginate or truncate in front, truncate or sinuate at base, dentate anteriorly, not transversely depressed behind anterior margin; sides not margined. Scutellum small, subtriangular, truncate at apex. Elytra strongly convex; lateral submargins on apical declivity very strongly elevated at apices; each elytron trituberculate along anterior margin of apical declivity. Legs short, subequal in length; tibiae expanded toward apices, dentate on exterior margins, each with a large, arcuate spine at apex; posterior tarsi as long as tibiae, apical segment of each shorter than preceding four segments united. Anterior coxae contiguous. Middle coxae narrowly separated. Intercoxal process of abdomen lamellate. Body short, cylindrical.

Genotype.-Xylopertha hexacantha Fairmaire. (Present designation.)

Lesne (1901) erected Xyloprista for Xyloprista arcellata new species, Xylopertha praemorsa Erichson, and Xylopertha hexacantha Fairmaire without designating a genotype. All of these species are found in the warmer parts of South America.

Xyloprista heXacantha (Fairmaire)

Xylopertha hexacantha Fairmaire, 1S92, Soc. Ent. de Belg. Ann. 36: 245.

Xyloprista hexacantha Lesne, 1901, Soc. Ent. de France Ann. (1900) 69: 499, 501502, figs. 285, 291; 1938, in Junk (pub.), Coleopt. Cat., pt. 161, p. 55.

Male.-Uniformly reddish brown or brownish black, the antennae, palpi, and posterior margins of abdominal sternites brownish yellow, legs reddish.

Head moderately convex, with two to four distinct tubercles on front, densely, coarsely granulose, and sparsely clothed with long, recumbent and erect, whitish hairs on front, with short, longitudinal, parallel costae on occiput; clypeus finely, transversely rugose or granulose; clypeal suture not distinct.

Pronotum slightly wider than long, widest at middle; sides broadly, arcuately rounded, more strongly converging anteriorly, with a small, broad tooth at apical angles; posterior angles broadly rounded; surface sparsely clothed with short, recumbent, inconspicuous hairs, very finely, sparsely punctate at sides on basal half, finely, densely imbricatepunctate at middle on basal half, rather densely, irregularly dentate on apical half, the teeth broad, semierect, variable in size, and rasplike, with a few larger teeth toward apical angles.

Elytra at base slightly narrower, or subequal in width to pronotum at middle; sides parallel, or vaguely expanded posteriorly, angularly separated at apices; surface nearly glabrous on basal half, sparsely pubescent toward apical declivity, densely clothed with short, recumbent, brownish hairs on apical declivity, densely, coarsely punctate on basal two-thirds, more shallowly punctate on apical declivity; humeral 
callosity nearly impunctate; apical declivity with lateral submargins very strongly elevated, especially toward apices, extending to outer tubercles, acutely, angularly separated at sutural angles, the sutural margins feebly, broadly elevated; each elytron with two obsolete, longitudinal costae, and three large, acute tubercles along anterior margin of apical declivity, the tubercles spinose at apices, and outer one slightly arcuate.

Abdomen beneath finely, densely punctate, rather densely clothed with moderately long, recumbent, yellowish hairs, with a few longer hairs on last visible sternite, which is broadly rounded at apex.

Female.-There are scarcely any external differences in the sexes. The tuber'cles on the front of the head are usually larger in the female than in the male, the front of the head is more densely pubescent, and the pubescence is longer on the first antennal segment.

Length 4-6 mm., width $1.5-2 \mathrm{~mm}$.

Type locality.-Rioja Province, Argentine Republic; present location of type unknown to writer.

Distribution.-This species is recorded in the literature from the Argentine Republic, Brazil, Bolivia, Paraguay, and Uruguay. Specimens have been intercepted at Miami Beach, Fla., February 12, 1943, on an aircraft arriving from Buenos Aires, Argentine Republic. So far as known, it is not established in the United States.

Hosts.-Nothing is recorded on the habits of this species.

Genus XYLOMEIRA Lesne

Xylomeira Lesne, 1901, Soc. Ent. de France Ann. (1900) 69 : 475, 502-504; 1938, in Junk (pub.), Coleopt. Cat., pt. 161, p. 55.

Head deeply inserted in prothorax, not visible from above; clypeus strongly transierse, truncate in front, with a small tooth on each side at base of labrum; labrum transverse, arcuately emarginate or truncate and densely ciliate with long yellow hairs in front; mandibles more or less attenuate toward apices; eyes very large, oval, globose, strongly projecting. Antenna rather long, 10-segmented; first and second segments robust, first broad, flattened, clothed with long, yellow hairs, second elongate, much shorter than first; third to seventh small, transverse, gradually wider toward seventh, the segments united shorter than first segment of club; last three segments forming a loose, compressed club, densely clothed with short, erect hairs, each with two more or less distinct sensory depressions on each surface, eighth and ninth broadly oblong or oval, tenth narrowly oblong, longer than ninth. Pronotum stongly convex, arcuately emarginate or truncate in front, truncate at base, dentate anteriorly, not transversely depressed behind anterior margin; sides not margined. Scutellum rather large, triangular, subtruncate at apex. Elytra strongly convex, each elytron with three costiform tubercles on anterior margin of apical declivity, the tubercles obtuse at apices. Legs short, subequal in length; tibiae expanded toward apices, longitudinally carinate, dentate on exterior margins, each with a large, arcuate spine at apex; posterior tarsi as long as, or longer than tibiae, apical segment of each shorter than preceding four segments united. Anterior coxae contiguous. Middle coxae narrowly separated. Intercoxal process of abdomen lamellate. Body elongate, cylindrical.

Genotype.-A pate torquata Fabricius. (Monobasic.) 


\section{XYlomeira torquata (Fabricius)}

Apate torquata Fabricius, 1801, Systema Eleutheratorum, v. 2, p. 382.

Xylomeira torquata Lesne, 1901, Soc. Ent de France Ann. (1900) 69: 503-504, figs. $292-295$; 1938, in Junk (pub.), Coleopt. Cat., pt. 161, p. 55.

?Apate tridens Fabricius (not Lesne 1901), 1792, Ent. System., v. 1, pt. 2, pp. 362-363 ; Herbst, 1793, Natursystem Insekten, Käfer, v. 5, p. 76 ; Fabricius, 1801, Systema Eleutheratorum, v. 2, p. 381; Lesne, 1937, Soc. Ent. de France Bul. 42 : 239.

Sinoxylon floridanum Horn, 1885, Amer. Ent. Soc. Trans. 12 : 155 ; Schwarz, 1890, Wash. Ent. Soc. Proc. 1: 177; Belkin, 1940, Ent. News 51: 192.

Xylobiops floridanus Lesne, 1901. Soc. Ent. de France Ann. (1900) 69: 506, $513-514 ; 1938$, in Junk (pub.), Coleopt. Cat., pt. 161, p. 60.

Xylopertha sextuberculata Gorham (not LeConte), 1898, Zool. Soc., London, Proc., p. 329.

Male.-Strongly shining, brownish black to reddish brown, the reddish-brown specimens usually with apical declivity of elytra brownish black; antennae, palpi, and usually legs brownish yellow.

Head moderately convex, vaguely, transversely depressed near occiput, sometimes with two vague tubercles on front, densely, finely granulose or punctate, sparsely clothed with short, recumbent, yellowish hairs; clypeus flat, sparsely, finely punctate, sometimes vaguely depressed at middle; clypeal suture vaguely indicated; mandibles without a distinct tooth near base on dorsal surface.

Pronotum slightly wider than long, widest near middle, arcuately declivous along anterior margin; sides broadly rounded, more strongly converging anteriorly, with a broad, erect tooth at apical angles; posterior angles broadly rounded; surface sparsely clothed with long, fine, erect hairs along sides on anterior half, and with short, recumbent hairs on basal half, very finely, sparsely, irregularly punctate at sides on basal half, rather densely covered with small, cuneiform reliefs at middle on basal half, densely, irregularly dentate on apical half, the teeth broad, semierect, variable in size, and rasplike, with a few larger teeth on each side toward apical angles, densely, finely granulose along anterior margin.

Elytra at base subequal in width to pronotum at middle; sides slightly expanded posteriorly, conjointly broadly rounded at apices, not tuberculate on underside of lateral margins: surface densely, coarsely, deeply punctate, the punctures coarser on apical declivity, and usually arranged in rows between tubercles, densely clothed with short, recumbent, yellowish hairs on apical declivity; apical declivity with lateral submargins moderately elevated and united with lateral margins along declivity, then curving inward to near outer tubercles, the sutural margins slightly elevated; each elytron with three long, strongly elerated, costiform tubercles along anterior margin of apical declivity, the tubercles obtusely rounded at apices.

Body beneath finely, densely punctate, rather densely clothed with moderately long, recumbent, yellowish hairs; last visible abdominal sternite broadly rounded at apex.

Female.-Differs from the male in having the front of head broadly flattened or concave, limited posteriorly by a transverse, arcuate elevation and with surface finely, sparsely punctate, the mandibles with a distinct tooth near the base on the dorsal surface, the first segment of the antenna with long, dense pubescence, the pronotum broadly concave behind the anterior margin, densely granulose and densely clothed with long, erect, yellowish hairs, the last visible abdomina] 
sternite transversely depressed and deeply, arcuately emarginate on each side of a median, bifid lobe, and the lateral margins of the elytra tuberculate on the underside near the apices, with the tubercles fitting into the emarginations on the last visible abdominal sternite.

Length 3-5 mm., width 1.2-1.5 mm.

Type locality.-Of torquata, "America meriodionali"; of tridens, St. Thomas Island, West Indies; types in the Copenhagen Museum. Of floridana, Florida; type in the Horn Collection in the Academy of Natural Sciences of Philadelphia.

Distribution.-From material examined:

FlonidA: Biscayne, May 5; Key West, April; Lake Worth (Hubbard and Schwarz, and F. Knab). Marathron, March 7-8, 1919 (E. A. Schwarz). Paradise Key, February 5 to March 3 (H. S. Barber and T. E. Snyder).

Texas: Laredo, October 20, 1908 (Mitchell and Bishopp). Brownsrille, May (H. S. Barber, F. C. Craighead, Jones and Pratt, and C. Schaeffer).

Mexico: Cordoba, March 20 to May 17 (F. Knab).

West Indes: St. Croix, Tortola, Puerto Rico, Antigua, Jamaica, St. John, MIontserrat, Eleuthera, Dominican Republic, Martinique, and Mona Island.

Hosts.-This species has been reared from horsebean (Parkinsonia aculeata, royal poinciana (Poinciana sp.), huisache (Acacia farnesiana), and dead tamarind (Tamarindus sp.).

Fabricius (1792) described tridens from St. Thomas Island and in (1801) described torquata from America meridionali. Lesne (1901) on first information given to him on the type of Apate tridens Fabricius (1792) associated it with Tetrapriocera longicornis Olivier (1795), but the material before him proved to be the male of Apate torquata Fabricius (1801), which was originally described from a female specimen, upon which he erected his new genus Xylomeira. Dr. Henrikson, of Copenhagen, at the request of Dr. Lesne. reexamined the type of tridens and reported that the characters of the anterior part of the type were that of the male of Xylomeira torquata, while those of the posterior part resembled those of Tetrapriocera longicornis. Owing to this condition, Lesne thought it advisable to abandon the name tridens for torquata, although the former had ? years' priority.

Horn (1885) described floridanum from a single female specimen, but Belkin (1940) placed it as a synonym of torquata Fabricius.

\section{Genus XYLOBIOPS Casey}

Xylobiops Casey, 1898, N. Y. Ent. Soc. Jour. 6: 66, 67 ; Lesne, 1901, Soc. Ent. de France Ann. (1900) 69: 476, 505-514, figs. 296-300; 1938, in Junk (pub.), Coleopt. Cat., pt. 161, p. 60.

Head deeply inserted in prothorax, not visible from above; clypeus strongly transverse, truncate in front, with a distinct tooth on each side at base of labrum; labrum small, raguely emarginate or subtruncate and densely ciliate with long, yellow hairs in front: mandibles attenuate toward apices; eyes oral, globose, strongly projecting. Antenna 10-segmented; first and second segments robust, first long, arcuate, second one-third as long as first; third to serenth segments short, compact, transverse except sometimes the third, united shorter than first segment; last three segments forming a large, loose, compressed club, each with two more or less distinct sensory depressions on each surface, the eight subtriangular, ninth oblong, and tenth narrowly elongate, longer than ninth. Pronotum strongly convex, arcu- 
ately emarginate or subtruncate in front, shallowly, arcuately emarginate at base, dentate anteriorly, not transversely depressed behind anterior margin; sides not margined. Scutellum small, quadrate. Elytra strongly convex, each elytron with three tubercles on anterior margin of apical declivity, the tubercles subtriangular, and at least one spinose at apex. Legs short, subequal in length; tibiae slightly expanded toward apices, each with a large, arcuate spine at apex, anterior pair distinctly dentate on exterior margins; posterior tarsi as long as, or longer than tibiae, apical segment of each shorter than preceding four segments united. Anterior coxae contiguous. Middle coxae nariowly separated. Intercoxal process of abdomen lamellate. Body elongate, cylindrical.

Genotype.-A pate basitaris Say. (Present designation.)

Casey (1898) proposed Xylobiops for Apate basilaris (Say), Sinoxyton texanum Horn, S. sextuberculatum IeConte, and S. floridanum Horn, without selecting a genotype. Belkin ${ }^{10}$ transferred Sinoxylon floridanum to the genus Xylomeira as a synonym of torquata Fabricius. This species was unknown to Lesne (1901), but he retained it under $X$ ylobiops without separating it from the other species in his table.

\section{KEY TO THE SPECIES OF XYLOBIOPS}

1. Dorsal surface of elytra (except apical declivity) without distinct pubescence, the yellow and black or brown areas conspicuously separated.--

Dorsal surface of elytra (except along base) with distinct pubescence, the light and dark-brown areas not conspicuously separated

2. Inner two pairs of tubercles along anterior margins of apical declivity of elytra acute or spinose at apices and coarsely punctured between tubercles, the surface of declivity coarsely, evenly punctured in female, with a

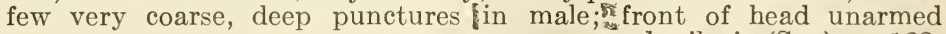
basilaris (Say), p. 122.

Inner two pairs of tubercles along anterior margins of apical declivity of elytra not spinose at apices, and not coarsely punctured between tubercles, the surface of declivity sparsely, finely, irregularly punctate in female, nearly impunctate in male; front of head with two median tubercles in both sexes_..._._. . .

3. Apical declivity of elytra sparsely, coarsely punctured; front of head usually with two median tubercles in both sexes___texanus (Horn), p. 125.

Apical declivity of elytra not, or very finely, punctured; front of head with four to six small tubercles in female, unarmed in the male . sextuberculatus (LeConte), p. 126.

\section{XYlobiops basilaris (Say)}

Apate basilaris Say, 1824, Acad. Nat. Sci. Phila. Jour. 3: 321-322; 1859, Complete Writings (LeConte ed.), v. 2, p. 181.

Apate basillaris Harris, 1841 , Insects Injurious to Vegetation, p. $76 ; 1852$, ed. 2, p. $8 ; 1863$, new ed., p. $92 ; 1890$, Flint ed., p. 92 ; Packard, 1890, U. S. Ent. Commr. Rpt. 5 : 296 , fig. 119.

Sinoxylon basilare Horn, 1861, Ent. Soc. Phila. Proc. 1 : 29 ; Riley, 1872, Noxious, Beneficial, and Other Insects of Missouri, 4th Ann. Rpt., pp. 53-54, figs. 26-27; Horn, 1878, Amer. Phil. Soc. Proc. 17: 542; Schwarz, 1888, Insect Life 1: 162; 1890, Ent. Soc. Wash. Proc. 1: 177; Hopkins, 1893, W. Va. Agr. Expt. Sta. Bul. 32: 189; Lintner, 1896, N. Y. State Mus. Rpt. 49 (1895), p. 268; Blatchley, 1910, Coleoptera of Indiana, p. 888, fig. 349; Robinson, 1912, N. Y. Ent. Soc. Jour. $20: 292$.

Xylobiops basilaris Casey, 1898, N. Y. Ent. Soc. Jour. 6: 67 ; Lesne, 1901, Soc. Ent. de France Ann. (1900) 69: 506, 507-509, figs. 296, 297; Leonard, 1928,

${ }^{10}$ Belkin, J. N. NOtes on NORTh aMerican bostrichidae (COLEoptera). Ent. News $51: 192,1940$. 
N. Y. (Cornell) Agr. Expt. Sta. Mem. 101: 415; St. George, 1929, U. S. Dept. Agr. Farmers' Bul. 1582, pp. 6-8, figs. 8-12; Lesne, 1938, in Junk (pub.) Coleopt. Cat., pt. 161, p. 60 ; Brimley, 1938, Insects of North Carolina, p. 197; Anderson, 1939, Wash. Acad. Sci. Jour. 29 (9) : 391 (larvae) ; Belkin, 1910, Ent. News 51: 192.

A pate basalis Dejean, 1935, Cat. Coléopt., ed. 3, p. 309 ; 1936, ed. 3 rev., p. 334.

Apate humeralis Melsheimer, 1806, Catalogue of Insects of Pennsylvania, p. 129; Melsheimer, 1853, Catalogue of the described Coleoptera of the United States, p. 84 .

Male.-Brownish black to dark reddish brown, with humeri or base of elytra reddish; antennae, palpi, and tarsi brownish yellow, the clypeus often slightly reddish.

Head slightly convex, without distinct median tubercles on front, sometimes longitudinally grooved on front, densely, finely granulose, with fine, longitudinal, parallel costae on occiput, sparsely clothed with short, recumbent, inconspicuous hairs; clypeus vaguely convex, densely, finely granulose, sparsely clothed with short, recumbent, inconspicuous hairs; clypeal suture deeply depressed at middle, obsolete on each side.

Pronotum quadrate or vaguely wider than long, widest along middle; sides vaguely rounded, or parallel along middle, more strongly converging anteriorly, with a short, broad tooth near apical angles; posterior angles broadly rounded; surface sparsely clothed with short, recumbent and semierect inconspicuous hairs on basal half and median part of apical half, and long, erect hairs toward lateral margins on apical half, finely, densely scabrous, with numerous broad, semierect, rasplike teeth on apical half.

Elytra at base subequal in width to pronotum at middle; sides nearly parallel, conjointly broadly rounded at apices; surface glabrous on disk, sparsely clothed with short, recumbent, brownish hairs on apical declivity, coarsely, densely, irregularly punctate on basal twothirds; apical declivity with a few large, deep, foveolate punctures on each side and between tubercles, smooth along sutural margins, which are slightly, broadly elevated, the lateral margins strongly elevated; each elytron with two or three short, broadly rounded, smooth costae at base, and with three costiform tubercles along anterior margin of apical declivity, the tubercles rather short, and acute at apices.

Abdomen beneath densely, finely granulose, indistinctly punctate, rather densely clothed with short, recumbent, whitish hairs, with a few long, erect hairs on last visible sternite, which is broadly subtruncate at apex.

F emale.-Differs from the male in having the last visible abdominal sternite slightly longer, and feebly, narrowly emarginate at the apex, and the punctures on the apical declivity of the elytra smaller, more numerous, and distributed over nearly all of the surface.

Length 4-7 mm., width 1.5-2.5 mm.

Type locality.-Of basilaris, along the Ohio, Mississippi, and Arkansas Rivers; since the type of basilaris is lost, the writer is designating a specimen in the United States National Museum, labeled 2 miles west of St. Louis, Mo., May 23, 1904, collected by WV. V. Warner, as the neotype. Of basalis, "Amérique Boréale"; location of type unknown to writer. Of humeralis, Pennsylvania; type probably lost.

Distribution.-This common species is widely distributed over the eastern half of the United States. Material has been examined from 
many localities in Arkansas, Delaware, District of Columbia, Florida, Georgia, Illinois, Indiana, Iowa, Kansas, Kentucky, Louisiana, Maryland, Massachusetts, Mississippi, Missouri, New Jersey, New York, North Carolina, Ohio, Pennsylvania, South Carolina, Tennessee, Texas, Virginia, West Virginia, and Wisconsin, and has been recorded in the literature from southeastern Canada.

Hosts.-This species has been reared from oak (Quercus spp.), ash (Fraxinus sp.), persimmon (Diospyros virginiana L.), mockernut hickory (Hicoria alba (L.) Britton), red mulberry (Morus rubra L.), dry bamboo (Phyllostachys sulphurea viridis Young), American elm (Ulmus americana L.), peach (Amygdalus persicae L.), apple (Malus sp.), honeylocust (Gleditsia triacanthos L.), redbud (Cercis canadensis L.), black locust (Robinia pseudoacacia L.), pecan (Hicoria pecan (Marshall) Britton), pear (Pyrus communis L.), pricklyash (Aralia spinosa L.), tamarack (Larix laricina (DuRoi) Koch), poison sumac (Rhus vernix L.), grape (Vitis sp.), poison-ivy (Rhus toxicodendron L.), English elm (Ulmus campestris L.), and blue gum (Eucalyptus globutus Labill.). Sometimes the adults damage finished wooden articles.

\section{XyLOBIOPS PARILIS Lesne}

Xylobiops parilis Lesne, 1901, Soc. Ent. de France Ann. (1900) 69 : 506, 510; 1938, in Junk (pub.), Coleopt. Cat., pt. 161, p. 60 ; Belkin, 1940, Ent. News 51: 192.

Male.-Brownish black to dark reddish brown, with base of elytra reddish or brownish yellow; antennae, palpi, anterior coxae, last visible abdominal sternite in part, and legs (except anterior tibiae) brownish yellow.

Head slightly convex, with two small, median tubercles on front, sometimes with a longitudinal groove between tubercles, densely, finely granulose on front, with fine, longitudinal, parallel costae on occiput, sparsely clothed with short, recumbent, inconspicuous hairs; clypeus vaguely convex, sparsely, shallowly punctate or finely granulose, sparsely clothed with short, recumbent, inconspicuous hairs; clypeal suture deeply depressed at middle, obsolete at sides.

Pronotum quadrate or slightly wider than long, widest along middle; sides vaguely rounded or parallel along middle, more strongly converging anteriorly; apical and posterior angles broadly rounded, the former usually with a small tooth near margin; surface sparsely clothed with short, recumbent, inconspicuous hairs, with a few rather long, semierect, arcuate hairs on apical half toward lateral margins, smooth and indistinctly punctate at sides, finely, densely scabrous at middle on basal half, densely, irregularly dentate at middle on apical half, the teeth broad, semierect, variable in size, and rasplike.

Elytra at base subequal in width to pronotum along middle; sides nearly parallel, conjointly broadly rounded at apices; surface glabrous on disk, rather densely clothed with short, recumbent, yellowish hairs on apical declivity, coarsely, densely, irregularly punctate on basal two-thirds, the punctures finer toward sides and base; apical declivity finely, sparsely, indistinctly punctate, not coarsely punctate between tubercles, the sutural margins slightly, broadly elevated, and lateral margins strongly elevated; each elytron with three costiform tubercles along anterior margin of apical declivity, the two inner tubercles short and obtuse at apices, the outer one long, and usually spinose at apex, and without distinct costae at base. 
Abdomen beneath sparsely, indistinctly punctate, rather densely clothed with short, recumbent, whitish hairs, the hairs longer on last visible sternite, which is slightly longer than preceding sternite, and broadly subtruncate at apex.

Female.-Differs from the male in having the apical declivity of the elytra more coarsely punctured, especially toward the sides, and the last visible abdominal sternite twice as long as the preceding sternite.

Length 3.75-5.5 mm., width 1.4-2 mm.

Type localities.-Guanajuato, Mexico, and Lower California; types in the Paris Museum. "Mexico"; type was in the Berlin Museum. Distribution.-From material examined:

ARIzona: Sabino Canyon, reared in large numbers from mesquite (Prosopis juliflora (Swartz) de Candolle) (G. Hofer). Tucson, April 21, 1894, adults boring in lemon twigs (J. W. Toumey).

Hosts.-This species has been intercepted a number of times at Nogales, Ariz., in dry bamboo canes from Mexico. It has been found infesting bamboo (Arundinaria longifolia) from Mexico in storage at Hoboken, N. J., during September 1944.

Lesne (1901) described paritis from three specimens, one in the Berlin Museum labeled Mexique, and two females from Guanajuato, Mexico, and Lower California, in the Paris Museum, but in his Catalogue (1938) only listed this species from Mexico.

\section{Xylobiops texanus (Horn)}

Sinoxylon texanum Horn, 1878, Amer. Phil. Soc. Proc. 17: 542, 543; Schwalz, 1888, Insect Life $1: 162 ; 1890$, Ent Soc. Wash. Proc. $1: 177$.

Xylobiops texanus Casey, 1898, N. Y. Ent. Soc. Jour. 6: 67; Lesne, 1901, Soc. Ent. de France Ann. (1900) 69:506-507, 511; 1938, in Junk (pub.), Coleopt. Cat., pt. 161, p. 60) ; Anderson, 1939, Wash. Acad. Sci. Jour. 29 (9) : 391, figs. 39, 43 (larvae) ; Belkin, 1940, Ent. News 51: 192.

Male.-Reddish brown, sometimes with the head, pronotum in part, and apex of elytra darker; antennae, palpi, anterior coxae, last visible abdominal sternite, and legs (except anterior tibiae) brownish yellow.

Head slightly convex, usually with two small, median tubercles on front, densely, finely granulose, with a few larger granules intermixed on front, with fine, longitudinal, parallel costae on occiput, sparsely clothed with short, recumbent, inconspicuous hairs, with a few longer, erect hairs intermixed; clypeus nearly flat, densely, shallowly punctate, sparsely clothed with short, recumbent, inconspicuous hairs; clypeal suture deeply depressed at middle, obsolete at sides.

Pronotum quadrate or slightly wider than long, widest along middle; sides vaguely rounded or parallel along middle, more strongly converging anteriorly; apical and posterior angles broadly rounded: surface sparsely clothed with short, recumbent, inconspicuous hairs, with numerous long, erect hairs on apical half toward lateral margins, sparsely, indistinctly punctate at sides, finely, densely granulose on median part of basal half, densely, irregularly dentate on apical half, the teeth broad, semierect, variable in size, and rasplike.

Elytra at base subequal in wirlth to pronotum along middle; sides nearly parallel, conjointly broadly rounded at apices; surface densely clothed with short, recumbent, whitish hairs, except sometimes at base. rather densely, coarsely, irregularly, shallowly punctate on disk; apical 
declivity sparsely, deeply, coarsely, irregularly punctate, the sutural margins slightly, broadly elevated, and lateral margins strongly elevated; each elytron with vaguely indicated costae at base, and with three costiform tubercles along anterior margin of apical declivity, the tubercles (except sometimes the sutural one) spinose at apices.

Abdomen beneath finely, densely, indistinctly granulose or punctate, sparsely clothed with rather long, recumbent, whitish hairs; last visible sternite slightly longer than preceding sternite, and broadly rounded at apex.

Female.-Differs from the male in having the last visible abdominal sternite twice as long as the preceding sternite, and the apical declivity of the elytra not so deeply depressed.

Length 3-5 mm., width 1-1.9 mm.

Type locality.-Southwestern Texas; type in the Horn Collection in the Academy of Natural Sciences of Philadelphia.

Distribution.-From material examined:

Texas: Specimens of this species have been collected at many localities in the State by various collectors.

MExico: Victoria, collected on dead fig twig by E. A. Schwarz.

This species has been intercepted at Nogales, Ariz., in mesquite from Santa Ana, Sonora, Mexico. Schwarz (1888) reported finding adults near Washington, D. C.

Hosts.-This species has been reared from mesquite (Prosopis juliflora (Swartz) de Condolle), huisache (Acacia farnesiana (L.) Willdenow), huajillo (Pithecolobium brevifolium Bentham), and horsebean (Parkinsonia aculeata L.). H. J. Reinhard reported it infesting nursery stock at College Station, Tex., during May 1939.

\section{Xylobiops SeXtuberculatus (LeConte)}

Sinoxylon sextuberculatum LeConte, 185S, Acad. Nat. Sci. Phila. Proc. 10: 73-74; Horn, 1878, Amer. Phil. Soc. Proc. 17: 542, 543.

Xylopertha sextuberculatum Gorham, 1Ss3, Biol. Centr.-Amer., Coleopt., v. 3, pt. 2 , p. $216 ; 1886$, sup. p. 353.

Tylobiops sextuberculatus Casey, 1898, N. Y. Ent. Soc. Jour. 6 : 67 ; Lesne, 1901,

Soc. Ent. de France Ann. (1900) 69:507, 512-513, figs. 299, 300; 1938, in Junk

(pub.), Coleopt. Cat., pt. 161, p. 60 ; Belkin, 1940, Ent. News 51: 192.

Male.-Brownish or reddish black; elytra reddish brown, sometimes paler at base; antennae, palpi, and legs (except anterior tibiae) brownish yellow.

Head slightly convex, unarmed and densely, finely granulose on front, with fine, longitudinal, parallel costae on occiput, sparsely clothed with short, recumbent, inconspicuous hairs, with a few long, erect hairs intermixed; clypeus vaguely convex, densely, shallowly punctate, sparsely clothed with short, recumbent, inconspicuous hairs; clypeal suture deeply depressed at middle, obsolete at sides.

Pronotum slightly wider than long, widest along middle; sides nearly parallel or vaguely rounded along middle, more strongly converging anteriorly; apical and posterior angles broadly rounded; surface sparsely clothed with short, recumbent, inconspicuous hairs, with a few long, erect hairs on apical half toward lateral margins, finely, sparsely, indistinctly punctate at sides, densely, finely scabrous at middle on basal half, densely, irregularly dentate on apical half, the teeth broad, semierect, variable in size, and rasplike. 
Elrtra at base subequal in width to pronotum along middle; sides nearly parallel, conjointly broadly rounded at apices; surface densely clothed with short, recumbent, brownish hairs, except at base, densely. rather coarsely, shallowly punctate on disk; apical declirity impunctate or very finely punctate, the sutural margins slightly, broadly elevated, and lateral margins very strongly elevated; each elytron with three more or less distinct, longitudinal costae, and with three costiform tubercles along anterior margin of apical declivity, the tubercles long, and spinose at apices.

Abdomen beneath finely, densely granulose or punctate, densely clothed with rather long, recumbent, whitish hairs; last visible sternite twice as long as preceding sternite, and broadly rounded or subtruncate at apex.

Female.-Differs from the male in haring four to six distinct tubercles on the front of the head, and the last risible abdominal sternite as long as the preceding two sternites united. transrersely, arcuately carinate at the middle, and produced into a lobe, which is obtusely rounded at the apex.

Length $3-5$ mm.. width $1.1-1.75 \mathrm{~mm}$.

Type locality.-Colorado Desert, Calif.; type in the LeConte Collection in the Museum of Comparative Zoology, Cambridge, Mass.

Distribution.-From material examined:

ArIzoxA: Santa Rita Mountains, May and June (Hubbald and Schwarz, and M. Chrisman). Catalina springs, April (Hubbard and Schwarz). Hot Springs (Barber and Schwarz). Sabino Canjon (G. Hofer). Redington (M. Chrisman). Tucson Mountains, March 9, 1937 (G. P. Englehardt). Tucson, July (Hubbard and Schwarz, J. L. Webb, and H. F. Wickham).

This species has been also recorded in the literature from California, Lower California, and Mexico.

Host.-This species has been reared a number of times from rarious localities in Arizona from mesquite (Prosopis juliflora (Swartz) de (andolle).

LeConte (185s) reported sextuberculatus as being abundant in the Colorado Desert, Calif.

\section{Genus DENDROBIELLA Casey}

Dendrobiella Casey, 1S9s, N. Y. Ent. Soc. Jour. 6 : 66, 67-6s, Lesne, 1901, Soc. Ent. de France Ann. (1900) 69: 475, 489-497, figs. 271-284; 1933, C. R. Congr. Soc. Sarantes de Paris, p. 23 , f. (publication not arailable); 1938, in Junk (pub.), Coleopt. Cat., pt. 161, pp. $55-\overline{5} 6$.

Head deeply inserted in prothorax, not risible from above; clypeus strongly transverse, truncate in front, with a small tooth on each side at base of labrum; labrum short, transverse, truncate and densely ciliate with long, yellow hairs in front; mandibles dissimilar, right mandible attenuate toward apex, left mandible toothed on inner margin, more strongly in female; eyes very large, oval, globose, strongly projecting. Antenna short, 10-segmented; first and second segments robust, first flattened and arcuate beneath, second elongate. much shorter than first; third to seventh segments small. transverse. compact, united shorter than first; last three segments forming a large. loose, compressed club, densely clothed with short, recumbent hairs. each with two rows of small, round, sensory depressions on each surface, the eighth subtriangular or securiform, ninth broadly oblong, and 
tenth narrowly elongate, narrower and longer than ninth. Pronotum strongly convex, truncate or emarginate in front, truncate at base, dentate anteriorly, not transversely depressed lsehind anterior margin, sides not margined. Scutellum small, quaduate. Elytra strongly convex, each elytron bituberculate along antırior margin of apical declivity. Legs short, subequal in length; tıbiae expanded toward apices, dentate on exterior margins, each with a large, arcuate spine at apex; posterior tarsi as long as, or longer than tibiae, apical segment of each shorter than preceding four segments united. Anterior coxae contiguous. Middle coxae narrowly separated. Intercoxal process of abdomen lamellate. Body rather short, cylindrical.

Genotype.-Sinoxylon asperum LeConte. (Present designation.)

Casey (1898) erected this genus for four species, sericans (a misidentification for aspera LeConte), quadrispinosa LeConte (now in Xyloblaptus Lesne), pubescens, and sublaevis, new species, without designating a genotype.

\section{KEY TO THE SPECIES OF DENDROBIELLA}

Elytra coarsely punctate over entire dorsal surface, the punctures coarse and deep near apical declivity................ aspera (Le Conte), p. 128.

Elytra not coarsely punctate over entire dorsal surface, the punctures becoming obsolete toward apical declivity, pubescence denser than in aspera. 129.

\section{Dendrobiella aspera (LeConte)}

Sinoxylon asperum LeConte, 1858, Acad. Nat. Sci. Phila. Proc. 10: 73.

Dendrobiella aspera Lesne, 1901, Soc. Ent. de France Ann. (1900) 69: 492, 496497, figs. 274-275, 282-283, 284; 1933, C. R. Congr. Soc. Sarantes de Paris, p. 239, fig. 1 (publication not a vailable); 1938, in Junk (pub.), Coleopt. Cat., pt. 161, pp. 55-56; Belkin, 1940, Ent. News 51: 192.

Sinoxylon sericans Horn, 1878 (not LeConte), Amer. Phil. Soc. Proc. 17: 542. Dendrobiella sericans Casey, 1898 (not LeConte), N. Y. Ent. Soc. Jour. 6: 67.

Male.-Brownish black to dark reddish brown, the antennae, palpi, legs (except anterior tibiae) reddish or yellowish brown.

Head moderately convex, slightly depressed at middle behind eyes, with two small, more or less distinct tubercles on front, densely, coarsely granulose, rather sparsely clothed with long, recumbent and erect, inconspicuous hairs; clypeus longitudinally grooved at middle, finely, sparsely punctate, sparsely clothed with short, recumbent, whitish hairs; clypeal suture usually obsolete; first segment of antennal club usually securiform, with the outer apical angle projecting outward.

Pronotum slightly wider than long, widest at middle, sides nearly parallel along basal half, arcuately converging anteriorly; anterior and posterior angles broadly rounded; surface sparsely clothed at sides with long, recumbent, yellowish hairs, the hairs very fine and inconspicuous on disk, shorter and more erect at middle on apical half, very finely, obsoletely punctate at sides on basal half, coarsely, imbricate-punctate at middle on basal half, rather densely, irregularly dentate on apical half, the teeth broad, semierect, variable in size, and rasplike.

Elytra at base subequal in width to pronotum at middle; sides slightly expanded posteriorly, conjointly broadly rounded at apices; surface rather densely clothed with short, recumbent, more or less 
distinct, arcuate, yellowish hairs, sparsely, finely punctate at sides, coarsely, deeply, densely punctate on disk, impunctate on apical declivity, apical declivity with lateral submargins slightly elevated, united with lateral margins, obtusely rounded on top, and curving inward to near exterior tubercles at anterior margin; sutural margins not distinctly elevated; each elytron with two costiform tubercles along anterior margin of apical declivity, the tubercles obtusely rounded at apices.

Abdomen beneath densely, finely punctate, densely clothed with short, recumbent, whitish hairs, with a few long, erect hairs intermixed on last visible sternite, which is broadly rounded at apex.

Female.-Differs from the male in having the front of the head flattened or concave, glabrous, shining, finely and sparsely punctate, with two small, distinct tubercles at the middle behind the eyes, the clypeal suture distinct and sulciform, the clypeus strongly convex, the left mandible more strongly toothed on inner margin near apex, and the last visible abdominal sternite thickened at the apex.

Length 5-7.5 mm., width $2.5-3 \mathrm{~mm}$.

Type locality.-Colorado Desert, at New River, Calif., type in the LeConte Collection in the Museum of Comparative Zoology, Cambridge, Mass.

Distribution.-From large series of specimens examined from many localities in Arizona, California, and Purissima, Lower California.

Hosts.-This species has been reared from paloverde (Cercidium torreyanum (Watson) Sargent), mesquite (Prosopis .juliflora (Swartz) de Candolle), and tamarisk (Tamarix gallica Linnaeus).

In a series of specimens there are very few constant characters for separating aspera and sericans. The first segment of the antennal club is variable in shape, and cannot be depended on entirely for separating the two species, as are also the markings on the front of the head. In sericans the punctures on the elytra are not quite so coarse, and are finer and obsolete toward the apical declivity, and the pubescence is more conspicuous and longer. Both species have about the same food habits, and may represent but one slightly variable species.

\section{Dendrobiella Sericans (LeConte)}

Sinoxylon sericans LeConte, 1858, Acad. Nat. Sci. Phila. Proc. 10 : 73.

Xylopertha sericans Gorham, 1883, Biol. Centr.-Amer., Coleopt., v. 3, pt. 2, pp. 215-216, pl. 10, fig. $21: 1886$, sup., p. 353 .

Dendrobiella sericans Lesne, 1901, Soc. Ent. de France Ann. (1900) 69: 491-492, 494-495, figs. 271, 280-281; 1933, C. R. Congr. Soc. Sarantes de Paris, p. 238, fig. 8 (publication not available) ; 1938, in Junk (pub.), Coleopt. Cat., pt. 161, p. 56; Anderson, 1939, Wash. Acad. Nat. Sci. Jour. 29 (9) : 391, figs. 35, 40-41, 44-45 (larvae).

Dendrobiella pubescens Casey, 1898, N. Y. Ent. Soc. Jour. 6: 67, 68; Belkin, 1940, Ent. News 51: 192.

Male.-Dark reddish brown, base of elytra and legs usually more reddish ; antennae, palpi, and tarsi, brownish yellow.

Head moderately convex, slightly depressed at middle behind eyes, with two small tubercles concealed by the pubescence on front, these tubercles sometimes obsolete, densely, coarsely granulose, densely clothed with long, erect and recumbent, yellowish hairs on front; clypeus sometimes longitudinally grooved at middle, finely, sparsely punctate, sparsely clothed with short, recumbent, whitish hairs; clypeal 
suture usually not distinct; first segment of antennal club subtriangular, with the outer apical angle not projecting outward.

Pronotum slightly wider than long, widest at middle; sides nearly parallel along basal half, arcuately converging anteriorly; anterior and posterior angles broadly rounded; surface densely, irregularly clothed with long, recumbent, yellowish hairs, which are shorter and more or less erect on anterior declivity, finely, densely punctate at sides on basal half, coarsely imbricate-punctate at middle on basal half, granulose and irregularly dentate on apical half, the teeth broad, semierect, variable in size, and rasplike.

Elytra at base subequal in width to pronotum at middle; sides slightly expanded posteriorly, conjointly broadly rounded at apices; surface densely clothed with short, recumbent, more or less arcuate, yellowish hairs, coarsely, sparsely, irregularly, shallowly punctate on basal half, finely, obsoletely punctate on apical declivity; apical declivity with lateral submargins slightly elevated and united with lateral margins, obtusely rounded on top, and curving inward to near exterior tubercles, sutural margins not distinctly elevated; each elytron with two long, costiform tubercles along anterior margin of apical declivity, the tubercles obtusely rounded at apices.

Abdomen beneath finely, densely punctate, densely clothed with long, semierect and recumbent, yellowish hairs; last visible sternite broadly rounded at apex.

Female.-Differs from the male in having the front of the head flattened or concave, glabrous, strongly shining, finely and sparsely punctate, and with two small, distinct tubercles at the middle behind the eyes, the clypeal suture distinct and sulciform, the left mandible more strongly toothed on the inner margin near the apex, and the last visible abdominal sternite thickened at the apex.

Length 5-7 mm., width 2-2.5 mm.

Type locality.-Of sericans, Ringgold Barracks, Tex.; type in the LeConte Collection in the Museum of Comparative Zoology, Cambridge, Mass. Of pubescens, Brownsville, Tex.; type in the Casey Collection in the United States National Museum.

Distribution.-From material examined:

Texas: Brownsville, May 4, 1904 (H. S. Barber); June to August (Charles Schaeffer).

Mexico: Nuevo Laredo, Tuxtepec, and Rosario.

Guatemala: El Rancho.

Hosts.-This species has been reared from horsebean (Parkinsonia aculeata Linnaeus), huisache (Acacia farnesiana (Linnaeus) Willdenow), mesquite (Prosopis juliflora (Swartz) de Candolle), royal poinciana (Poinciana regia (Rafinesque) Bojer), and chinaberry (Sapindus sp.).

Casey (1898) described pubescens from representatives of both sexes, from material collected at Brownsville, Tex. Lesne (1901) placed pubescens as a synonym of sericans LeConte.

\section{Genus XYLOBLAPTUS Lesne}

Xyloblaptus Lesne, 1901, Soc. Ent. de France Ann. (1900) 69: 476, 514-516, figs. 301-302 ; 1938, in Junk (pub.), Coleopt. Cat., pt. 161, p. 60 ; 1939, Rev. Franç d'Ent. 6: 118-123.

Head deeply inserted in prothorax, not visible from above; clypeus strongly transverse, with a tooth on each side at base of labrum; la- 
brum transverse, subtruncate and densely ciliate with long, yellowish hairs in front; manfdibles broad, more or less attenuate toward apices; eyes large, oval, globose, strongly projecting. Antenna moderately long, 10-segmented; first and second segments robust, first elongate, arcuate, slightly flattened on underside, second quadrate or oval, much shorter than first; third to seventh segments short, transverse, compact, united shorter than first segment; last three segments forming a large, loose, compressed club, the segments densely clothed with short, erect hairs, each with two round sensory depressions on each surface, eighth and ninth segments oval, subequal in length to each other, tenth elongate, longer and narrower than ninth. Pronotum strongly convex, truncate in front, broadly, arcuately emarginate at base, dentate anteriorly, not transversely depressed behind anterior margin; sides not margined. Scutellum small, quadrate. Flytra strongly convex, sutural margins scarcely elevated on apical declivity; each elytron with two tubercles along anterior margin of apical declivity. Legs short, subequal in length; tibiae flattened, slightly expanded toward apices, dentate on exterior margins, each with a moderately long, slightly arcuate spine at apex; tarsi slender, posterior pair as long as, or longer than tibiae, apical segment of each shorter than preceding four segments united. Anterior coxae contiguous. Middle coxae narrowly separated. Intercoxal process of abdomen lamellate. Last visible abdominal sternite long. Body short, cylindrical.

Genotype.-Sinoxylon quadrispinosum LeConte. (Monobasic.)

The females of this genus have a bunch of very long hairs extending backward from each side of the last visible abdominal sternite. These hairs are attached on the inside of the sternite at the lateral margins.

\section{KEY TO THE SPECIES OF XYLOBLAPTUS}

Tubercles along anterior margin of apical declivity of elytra spiniform at apices prosopidis, new species, p. 131.

Tubercles along anterior margin of apical declivity of elytra mamilliform, rarely acute, but not spinose at apices________ quadrispinosus (Le Conte), p. 132.

\section{XYLOBLAPTUS PROSOPIDIS, new species}

Male--Brownish black to dark reddish brown, with basal half of pronotum and elytra reddish or brownish yellow; underside of body reddish brown, the antennae, palpi, and legs (except sometimes anterior tibiae), brownish yellow.

Head slightly convex, with two small, obsolete, median tubercles on front, and a small smooth space behind the tubercles, sparsely, finely punctate on front and clypeus, with fine, longitudinal, parallel costae on occiput, sparsely clothed with rather long, erect and recumbent, white hairs; clypeus vaguely depressed at middle along posterior margin; clypeal suture distinct.

Pronotum distinctly wider than long, widest along middle; sides nearly parallel at middle, broadly rounded posteriorly and anteriorly; with a small, broad tooth at apical angles; surface sparsely clothed with short, recumbent and erect, inconspicuous hairs, which are more numerous on apical part, indistinctly punctate on basal half, with a few inconspicuous, cuneiform punctures on median part, rather densely, irregularly dentate on apical half, the teeth broad, semierect, variable in size, and rasplike, with two or three larger teeth on each side near apical angles. 
Elytra at base slightly narrower than pronotum along middle; sides slightly expanded posteriorly, conjointly broadly rounded at apices; surface rather densely clothed posteriorly with short, recumbent, whitish and brownish hairs, nearly glabrous on basal third, coarsely, densely, irregularly punctate on basal two-thirds, very finely, indistinctly punctate on apical declivity; sutural and lateral margins slightly elevated on apical declivity; each elytron with two large tubercles along anterior margin of apical declivity, the tubercles spiniform at apices.

Abdomen beneath finely, indistinctly granulose, sparsely clothed with short, recumbent, white hairs, with a few long, erect hairs on last visible sternite, which is broadly rounded or subtruncate at apex.

Female.-Differs from the male in having the front of the head more coarsely punctate, densely clothed with long, erect hairs, and with two distinct tubercles at the middle, and the last visible abdominal sternite about as long as the preceding sternites united, opaque, densely granulose, with a very deep emargination, which extends nearly to the base of the sternite.

Length $3.5-4.5 \mathrm{~mm}$., width 1.4-1.6 mm.

Type locatity.-Yermo, Calif.

Type, allotype, and paratypes.-In the United States National Museum, No. 58318.

Described from four specimens (one male type) collected at the type locality, November 27, 1937, from mesquite (Prosopis sp.) by P. C. Ting.

\section{XYloblaptus QUADRISPINOSUS (LeConte)}

Sinoxylon quadrispinosus LeConte, 1866, Smithsn. Inst. Misc. Collect. 167: 100 ; Horn, 1878, Amer. Phil. Soc. Proc. $17: 542,543$.

Xylopertha quadrispinosus Gorham, 1883, Biol. Centr.-Amer., Coleopt., v. 3, pt. 2, p. 217.

Dendrobiella quadrispinosus Casey, 1898, N. Y. Ent. Soc. Jour. $6: 67$.

Xyloblaptus quadrispinosus Lesne, 1901, Soc. Ent. de France Ann. (1900) 69: 514-516, figs. 301-302 ; 1938, in Junk (pub.), Coleopt. Cat., pt. 161, p. 60 ; 1939, Rev. Franç d' Ent. 6 : 118.

Male.-Head brownish black; pronotum and elytra reddish brown, the anterior part of pronotum slightly darker, and basal half of elytra brownish yellow; underside of body reddish brown, except antennae, palpi, legs (except sometimes anterior tibiae), and abdomen in part, brownish yellow.

Head slightly convex, with two small, obsolete, median tubercles on front, usually with a smooth spot behind tubercles, sparsely, finely punctate on front and clypeus, with fine, longitudinal, parallel costae on occiput, sparsely clothed with long, erect and recumbent, white hairs; clypeus longitudinally grooved at middle, broadly depressed at middle along posterior margin; clypeal suture distinct.

Pronotum distinctly wider than long, widest along middle; sides nearly parallel at middle, broadly rounded posteriorly and anteriorly, with a small, broad tooth at apical angles; surface sparsely clothed with short, recumbent and erect, inconspicuous hairs, which are more numerous on apical part, indistinctly punctate at sides on basal half. very finely, sparsely, cuneate-punctate on medial part of basal half, irregularly, densely dentate on apical half, the teeth broad, semierect, variable in size, and rasplike, with two or three larger teeth on each side near apical angle. 
Elytra at base subequal in width to pronotum along middle; sides slightly expanded posteriorly, conjointly broadly rounded at apices; surface rather densely clothed posteriorly with short, recumbent, white hairs, nearly glabrous on basal half, coarsely, densely, irregularly punctate on basal two-thirds, very sparsely, indistinctly punctate on apical declivity; sutural and lateral margins slightly elevated on apical declivity; each elytron with two large, mamilliform tubercles along anterior margin of apical declivity, the tubercles sometimes acute at apices but not spiniform.

Abdomen beneath densely, indistinctly granulose, sparsely clothed with short, recumbent, white hairs; last visible sternite broadly rounded or subtruncate at apex.

Female.-Differs from the male in having two small, distinct tubercles on the front of the head, the first four visible abdominal sternites narrower at the middle than at the sides, and the last visible abdominal sternite longer than the preceding sternites united, opaque, densely granulose and glabrous, and with a very deep, median emargination which extends nearly to the base of the sternite.

Length 2.75-4 mm., width 1.2-1.6 mm.

Type locality.-Cape San Lucas, Lower California; types in the LeConte Collection in the Museum of Comparative Zoology at Cambridge, Mass.

Distribution.-From material examined :

ARIzona : Catalina Springs, April 12-15, Oracle, June 30 (Hubbard and Schwarz).

Hot Springs (H. S. Barber and E. A. Schwarz). Sabino Canyon, March 9, 1917

(G. Hofer). Redington and Santa Catalina Mountains (M. Chrisman).

California: Palm Springs, July 11, 1932 (Blackwelder Collection).

Lower California : Purissima, October 23 (IV. M. Mann).

New Mexico: Las Cruces, November 13, 1893 (T. D. A. Cockerell).

Texas: Uvalde (W. F. Fiske).

Hosts.-This species has been reared from paloverde (Cercidium torreyanum (Watson) Sargent), mesquite (Prosopis juliflora (Swartz) de Candolle), and catclaw (Acacia greggii Gray).

LeConte described this species from two specimens collected by Xantus.

\section{Genus XYLION Lesne}

Xylion Lesne, 1901, Soc. Ent. de France Ann. (1900) 69: 478, 542-564; 1924, Bostrychides de l'Afrique Tropicale Française, pp. 209, 229-23S; 193s, in Junk (pub.), Coleopt. Cat., pt. 161, pp. 63-64.

Head deeply inserted in prothorax, not visible from above, convex or feebly, transversely depressed between eyes; clypeus strongly transverse, sinuate in front; labrum transverse, subtruncate and densely ciliate with long, yellow hairs in front; mandibles attenuate toward apices; eyes large, oblong, strongly projecting. Antennae 10-segmented; first and second segments robust, first oblong, slightly arcuate, subequal in length to second; third to seventh segments short, compact, transverse (except third), united shorter than first segment of club; last three segments forming a large, loose, compressed club, densely clothed with short, recumbent, yellowish hairs, each with small, indistinct, sensory depressions on each surface, the eighth subtriangular, ninth round, and tenth oblong, narrower than ninth. Pronotum strongly convex, truncate, or vaguely emarginate at base and apex, dentate anteriorly, not transversely depressed behind an- 
terior margin ; sides with a more or less distinct margin near posterior angles. Scutellum small, quadrate or slightly elongate. Elytra strongly convex, with distinct, irregular tubercles or processes at apical declivity, and lateral margins deeply, irregularly emarginate near apices in both sexes. Legs rather long, subequal in length; tibiae slightly expanded toward apices, each with a moderately long, arcuate spine at apex, anterior pair finely dentate on exterior margins; posterior tarsi much longer than tibiae, apical segment of each shorter than preceding four segments united. Anterior coxae contiguous. Middle coxae narrowly separated. Intercoxal process of abdomen lamellate. Body elongate, cylindrical.

Genotype.-Xylion securifer Lesne. (Present designation.)

Lesne (1901) erected Xytion for nine species from Africa and Australia, without designating a genotype.

\section{XyLion SECURifer Lesne}

Xylion securifer Lesne, 1901, Soc. Ent. de France Ann. (1900) 69: 546, 554-555, figs. 365, 366; 1924, Bostrychides de l'Afrique Tropicale Française, pp. 231, 232, 237, figs. 165-167; 1938, in Junk (pub.), Coleopt. Cat., pt. 161, p. 64.

Male.-Strongly shining, brownish yellow, with apical declivity of elytra reddish brown.

Head slightly, transversely flattened between eyes; front deflexed along anterior margin, glabrous, coarsely, sparsely punctate; occiput finely, irregularly rugose; clypeus flat, coarsely, shallowly punctate, the anterior margin with a short median lobe, which is feebly, arcuately emarginate; clypeal suture biarcuate, not very distinct.

Pronotum quadrate, widest along middle, slightly triangularly depressed at middle behind anterior margin; sides parallel or vaguely rounded at middle, broadly rounded anteriorly and posteriorly, with a broad, slightly arcuate tooth at apical angles, slightly margined near posterior angles but not along base; posterior angles broadly rounded; surface glabrous, sparsely, very finely, indistinctly punctate at sides on basal half, indistinctly imbricate-punctate on median part of basal half, densely, irregularly dentate on apical half, the teeth broad, semierect, variable in size, and rasplike.

Elytra at base subequal in width to pronotum at middle; sides slightly expanded posteriorly; surface glabrous, very finely, rather densely punctate on basal two-thirds, coarsely, irregularly punctate on apical declivity; sutural margins distinctly elevated on apical declivity, the margins expanded toward apical angles where they are conjointly narrowly emarginate; lateral margins deeply, narrowly, emarginate on each side below exterior process on apical declivity, then broadly subtruncate near apices; apical declivity obliquely deflexed, each elytron with a large, broad, arcuate, lateral process, which extends beyond tip of elytron, subtruncate at apex, nearly touching process of opposite elytron, and with three costiform tubercles along anterior margin of declivity, the middle tubercle arcuate, much longer than other tubercles, and acute at apex.

Abdomen beneath indistinctly punctate, sparsely clothed with a few short, recumbent, white hairs; last visible sternite normal, short, subtruncate at apex.

Female.-Differs from the male in having the sutural margins on apical declivity of the elytra more conjointly broadly emarginate at 
the apical angles, the lateral process on the apical declivity short and not extending to the tip of the elytron, the middle tubercle at anterior margin of the apical declirity short and not acute at the apex, the lateral margins of the elytra with a deep, oblong emargination in front of the lateral process, and a deep emargination beneath the process, shallowly emarginate near the apex, which is strongly elevated, and the first risible abdominal sternite short at middle and the other sternites very abnormal in shape.

Length 3-4.5 mm., width 1-1.3 $\mathrm{mm}$.

Type locality.-Northern Guinea, Sierra Leone, and Kamerun; location of types unknown to writer, but some are probably in the Paris Museum.

Distribution.-Specimens have been intercepted a number of times at New York and Baltimore under the bark of mahogany logs from the Gold Coast. Africa. Nothing has been recorded on the habits of this species. So far as known, this species has not become established in the United States.

Lesne (1901) described securifer from five males and three females collected along the Guinea coast from Sierra Leone to Kamerun, without designating any of the places as the type locality.

\section{Genus XYLOTHRIPS Lesne}

Xylothrips Lesne, 1901, Soc. Ent. de France Ann. (1900) 69: 479, 620-626; Jakobson, 1913, Käfer Russland, pt. 10, pp. \$0t, 806 ; Lesne, 1938, in Junk (pub.), Coleopt. Cat., pt. 161 , p. 6 T.

Head deeply inserted in prothorax, not risible from above; clypeus strongly transverse, arcuately emarginate in front; labrum transverse, broadly rounded or subtruncate and densely ciliate with long, yellow hairs in front: mandibles attenuate toward apices; eyes large, oblong, strongly projecting. Antenna 10-segmented; first and second segments robust, first slightly arcuate, elongate, second slightly shorter than first; third to serenth segments short, compact, transverse, united shorter than first segment of club; last three segments forming a large. loose, compressed club, densely clothed with rery short, yellow hairs, each with indistinct, elongate sensory depressions on each surface, the eighth and ninth segments oblong-rectangular, subequal in length to each other, tenth elongate, longer and narrower than ninth. Pronotum strongly convex, arcuately emarginate in front, truncate at base, dentate anteriorly, not transversely depressed behind anterior margin; sides margined along basal half, the margin extending along base for a short distance. Scutellum small, quadrate. Elytra strongly convex, with costiform tubercles along anterior margins of apical declivity. Legs short, subequal in length; tibiae slightly expanded toward apices, slightly dentate on exterior margins, each with a large. arcuate spine at apex, anterior pair longitudinally carinate on exterior surface; posterior tarsi as long as, or longer than tibiae, a pical segment of each shorter than preceding four segments united. Anterior coxae contiguous. Middle coxae narrowly separated. Intercoxal process of abdomen lamellate. Body elongate, cylindrical.

G'enotype.-A pate flavipes Illiger. (Present designation.)

Lesne erected Xylothrips for two species, A pate flavipes Illiger and A pate religiosus Boisdural, without designating a genotype. 


\section{KEY TO THE SPECIES OF XYLOTHRIPS}

Lateral submargins of elytra at anterior margins of apical declivity extending to lateral margin; lateral margins of elytra sinuate near sutural angles: tooth at apical angles of pronotum long and strongly curved; front of head of male without erect hairs, except for a few on each side near the eye flavipes (Illiger), p. 136.

Lateral submargins of elytra at anterior margins of apical declivity not extending to lateral margins; lateral margins of elytra not sinuate near sutural angles; tooth at apical angles of pronotum short and slightly curved; front of head of male with a transverse tuft of dense, moderately long, erect hairs on each side near the eye_..........-religiosus (Boisduval), p. 138.

\section{XYLOTHRIPS FLAVIPES (Illiger)}

Apate flavipes Illiger, 1801, Mag. f. Insektenkunde 1 (1-2) : 171-172.

Xylothrips flavipes Lesne, 1901, Soc. Ent. de France Ann. (1900) 69: 621-623, figs. 256-257, 474 ; 1904, Mission Pavie Indo-Chine, Ent. Div. 3 : 106 ; Jakobson, 1913, Käfer Russland, pt. 10, p. 806 ; Stebbing, 1914, Indian Forest Insects, pp. 151-152, fig. 99 ; Lesne, 1926, Treubia 7: 119; Froggatt, 1927, Forest Insects and Timber Borers, pp. 18, 101, pl. 3, figs. 1-7; Gardner, 1933, Indian Forest Rec., Ent. Ser. 18 (9) : 16-17, pl. 4, figs 53-54; Miller, 1934, Straits Settlements and Fed. Malay States, Dept. Agr. Sci. Ser. No. 14, pp. 1, 2, 26, pl. 1, fig. 1; Beeson and Bhatia. 1937, Indian Forest Rec., New Ser., Ent. 2:226, 230, 306-320, figs. 18-19, pl. 3, fig. b ; Lesne, 1938, in Junk (pub.), Coleopt. Cat., pt. 161, p. 67.

Apate sinuata Stephens (not Fabricius), 1830, Illus. Brit. Ent., Mandibulata. จ. 3, p. 351, pl. 19, fig. 6; Spry and Shuckard, 1840, British Coleoptera, p. 44, pl. 53, fig. 4.

Bostrichus mutilatus Walker, 1858, Ann. and Mag. Nat. Hist. (ser. 3), 2: 286 ; Waterhouse, 1888, Ann. and Mag. Nat. Hist. (ser. 6), 1: 349.

A pate religiosae Fairmaire, 1850, Rev. and Mag. Zool. (ser. 2) 2: 50 (part).

Apate dominica Fabricius, 1801, Systema Eleutheratorum, v. 2, p. 380.

Xylopertha dominicana Chevrolat, 1861, Soc. Ent. de France Ann. (ser. 4) 1: 392, Lesne, 1895, Soc. Ent. de France Ann. 64: Bul., p. CLXXVIII; 1897, Soc. Ent. de Belg. Ann. 41: 19.

Xylothrips dominicanus Lesne, 1901, Soc. Ent. de France Ann. (1900) 69: 621.

The bibliography given for this species is not complete, as only the more important articles are cited.

Male.-Strongly shining, brownish black, usually reddish on basal half of pronotum and elytra, sometimes entirely reddish; antennae, palpi, and body beneath brownish yellow.

Head slightly convex, sparsely, finely punctate and indistinctly pubescent on front, with a few long, erect hairs near eyes, densely, finely granulose and with fine, longitudinal, parallel costae on occiput; clypeus triangularly depressed at middle along anterior margin, smooth and impunctate along posterior margin, sparsely punctate along anterior margin, densely, finely punctate and densely clothed with short, erect hairs on median part; clypeal suture distinct, biarcuate, deeply depressed at middle.

Pronotum distinctly wider than long, widest at basal third; sides broadly rounded posteriorly, strongly converging anteriorly, with a large, unciform tooth at apical angles; posterior angles rectangular; lateral margins sinuate near base; surface glabrous, smooth and indistinctly punctate at sides and on basal half, densely, irregularly dentate on apical half, the teeth broad, semierect, variable in size, and rasplike, with four or five larger teeth on each side toward lateral margin.

Elytra at base subequal in width to pronotum at basal third; sides nearly parallel, conjointly broadly rounded at apices, the margins sinuate, slightly thickened and elevated at sutural angles; surface glabrous, sparsely, finely punctate on disk, more coarsely punctate on 
apical declivity, apical declivity with sutural margins slightly, uniformly elevated, the lateral submargins joined to lateral margins at anterior margin of declivity; each elytron with three more or less distinct costiform tubercles along anterior margin of apical declivity.

Abdomen beneath finely, densely punctate, densely clothed with short, recumbent, yellowish hairs; last visible sternite vaguely emarginate at apex, with narrow, smooth lateral pieces.

Female.-Differs from the male in having the front of the head and clypeus densely clothed with long and erect hairs, and the last visible abdominal sternite distinctly emarginate at the apex, with the lateral pieces smaller and pubescent.

Length 6-8.5 mm., width 2.5-3 mm.

Type locality.-Of flavipes, Africa: type was in the Zoological Museum at Berlin. Of sinuata, England; type in the British Museum. Of dominicana, East Indies: location of type unknown to writer. Of mutilatus, C'eylon: type either in the British Museum or the Hope Museum at Oxford.

Distribution.-This species is widely distributed throughout India, Indo-China, Madagascar and neighboring islands, and in the IndoMalaysian region, west of the channel separating Ceram from New Guinea. It has been recorded in the literature from India, Ceylon, Indo-China, Siam, Malay Peninsula, Formosa, Sumatra, Jara, Borneo, Celebes, Philippines, Amboine, Arou Islands, Ceram, Nicobar Islands, Madagascar, Comoro Islands, Seychelles, Reunion or Bourbon Islands, and Mauritius. Adults of this species have been found in wood in England, Natal, Arabia, and Zanzibar imported from the Malaysian region. This species has been intercepted at Los Angeles and San Francisco, Calif., and Seattle, Wash., in Philippine mahogany from the Philippines, and at Boston, Mass., in wooden cases from Batavia. So far as known, this species is not established in the United States.

Hosts.-Beeson and Bhatia (1937) recorded this species attacking the following plants: Albizzia odoratissima, Anacardium occidentale, Bombax malabaricum, Butea frondosa, Canarium strictum, Dipterocarpus turbinatus, Eugenia jambolana, Ficus glomerata, F. religiosa. Hevea sp., Hopea odorata, H. parviflora. Lannea grandis, Machilus odoratissima, Mallotus phitippinensis, Mangifera indica, Myristica longifolia, Parishia insignis, Phyllanthus emblica. Poinciana elata, Quercus sp., Shorea robusta, Terminalia bialata, T. myriocarpa, $T$. paniculata, T. tomentosa, Theobroma cacao, Vateria indica, V. lanceaefolia, Vitis vinifera, and Pterocarpus indicus. Miller (1931) recorded it from candlenut (Aleurites triloba Forst.). Froggatt (192i) stated that although not a native of Australia, it is very common in the seasoned saprood of Pacific maple (Shorea sp.), a timber imported in large quantities from the Philippines.

Stephens (1830) described sinuata from a specimen taken beneath the bark of a tree in Epping Forest, England. probably previously introduced in timber flom the Orient. Lesne (1901) placed dominicanus Fabricius, sinuatus Stephens, retigiosae Fairmaire (part), and mutilatus Walker as synonyms of flavipes Illiger. Both flavipes Illiger and dominicanus Fabricius were described in the same year, but Lesne (1901, p. 621) points out that the preface to parts 1 and 2 of the Illiger Magazine is dated March 1801, whereas the first volume of Systema Eleutheratorum is dated April 10, 1801. 


\section{Xylothrips Religiosus (Boisduval)}

Apate religiosa Boisduval, 1835, Voyage de l'Astrolabe, pt. 2, pp. 460-461; Fairmaire, 1850, Rev. and Mag. Zool. (ser. 2) 2:50 (part).

Rhizopertha religiosa MacLeay, 1886, Linn. Soc. N. S. Wales Proc. (ser. 2) 1: 154.

Xylopertha religiosa Lesne, 1895, Soc. Ent. de France Ann. 64: Bul. p. CLXXVII. Xylothrips religiosus Lesne, 1901, Soc. Ent. de France Ann. (1900) 69: 621, 624-626, figs. 473, 475-477; Froggatt, 1927, Forest Insects and Timber Borers, p. 102, pl. 30, figs. 3, 8; Chûjô, 1936, Formosa Nat. Hist. Soc. Trans. 26: 409; Lesne, in Junk (pub.), Coleopt. Cat., pt. 161, p. 67; Lever, 1945, Bul. Ent. Res. 35 (4) $373,375,376$.

Apate destructor Montrouzier, 1855, Lyon Soc. Agr. Ann. (ser. 2), 7 (1) : 55.

Apate lifuana Montrouzier, 1861, Soc. Ent. de France Ann. (ser. 4) 1: 267.

Xylopertha lifuana Redtenbacher, 1867, Reise der Novara, v. 2, p. 114; Waterhouse, 1888, Ann. and Mag. Nat. Hist. (ser. 6) 1:350; Lesne, 1896, Soc. Ent. de France Bul., p. 335 .

Male.-Strongly shining, black, with a vague raddish tinge; body beneath, antennal club, tibiae, and tarsi reddish brown; palpi, antennae (except clubs), femora, and anterior coxae brownish yellow.

Head slightly gibbose; front deflexed along anterior margin, densely, finely punctate, with a longitudinal, median, smooth space, rather densely clothed with moderately long, erect, yellow hairs on each side along anterior margin; occiput densely, rather coarsely granulose, the granules round at middle and elongate on each side; clypeus flat, coarsely, irregularly punctate, rather densely clothed with moderately long, erect, yellowish hairs, feebly, arcuately emarginate in front; clypeal suture distinct, biarcuate.

Pronotum distinctly wider than long, widest at basal third; sides broadly rounded posteriorly, strongly converging anteriorly, with a short, unciform tooth at apical angles; posterior angles rectangular; lateral margins arcuate near base; surface glabrous, smooth and finely, indistinctly punctate on basal half, more distinctly punctate at sides on apical half, densely, irregularly dentate on disk on apical half, the teeth broad, semierect, variable in size, and rasplike, with a few longer teeth on each side toward lateral margin.

Elytra at base subequal in width to pronotum at basal third; sides nearly parallel, conjointly broadly rounded at apices, the margins strongly elevated along apical declivity, thickened and more strongly elevated at sutural angles; surface glabrous, rather densely, coarsely punctate, the punctures finer near base and apex; apical declivity with sutural margins slightly, uniformly elevated, the lateral submargin short, not joined to lateral margin at anterior margin of declivity; each elytron with three more or less distinct costiform tubercles along anterior margin of apical declivity.

Abdomen beneath finely, densely punctate, rather densely clothed with short, recumbent, yellowish hairs; last visible sternite feebly emarginate and clothed with long hairs at apex, and with narrow, smooth, lateral pieces.

Female.-Differs from the male in having the front of the head and clypeus densely clothed with very long, erect, yellowish hairs, forming a transverse, arcuate crown on the front and two tufts on the clypeus, the last visible abdominal sternite more deeply emarginate at the apex, with the lateral pieces smaller and pubescent.

Length 5-8.5 mm., width 2-3 mm.

Type locality.-Of religiosus, "Dorei, Africa, Maurice and Bourbon Islands, and East Indies." Of destructor, Woodlark Island. Of 
lifuana, Lifu Islands, New Caledonia. The location of the types of these three species is unknown to the writer.

Distribution.-This species is widely distributed throughout the tropical parts of the Pacific Ocean. It is recorded from New Caledonia, New Hebrides, Samoa, Tahiti, New Britain, New Guinea, Hawaii, northeast Australia, Timor, Ternate, Molucca, and the Fiji, Marquesas, Woodlark, Solomon, Arou, and eastern Sunda Islands. It was intercepted at New York, April 13, 1939, in Cryptocarya palmerstoni logs from Australia, but so far as known, has not become established in the United States.

Hosts.-Lesne (1901) recorded religiosus as living in "Arbre à Pain" (Artocarpus inciso) and in "Bourao" (Hibiscus tiliaceus) in Tahiti. Jever (1945) reported it attacking branches of avocado pear (Persea americana), cocoa (Theobroma cacao), and in the roots of stored derris (Derris elliptica) in the Fiji Islands. Montrouzier (1861) recorded this species as injuring wooden constructions in New Caledonia.

Boisduval (1835) described religiosus from a number of widely separated localities without designating any of these places as the type locality. Some of the specimens used in describing this species, without any doubt, belong to flavipes Illiger. Lesne (1901) placed lifuana and destructor, both described by Montrouzier, as synonyms of flavipes Illiger. Froggatt (1927) stated that flavipes had been introduced in timber into England, Natal, and various places in Australia.

\section{Genus XYLOPSOCUS Lesne}

Xylopsocus Lesne, 1901, Soc. Ent. de France Ann. (1900) 69 : 479, 627-639 ; Jakobson, 1913, Käfer Russland, pt. 10, pp. 804, 806; Lesne, 1924, Bostrychides de l'Afrique Tropicale Française, pp. 209, 215-217; 1938, in Junk (pub.) Coleopt. Cat., pt. 161 , p. 68.

Head deeply inserted in prothorax, not visible from above; clypeus strongly transverse, truncate or shallowly emarginate in front, narrowly emarginate on each side at base of labrum; labrum small, transverse, truncate and densely ciliate with long, yellow hairs in front; mandibles variable, usually broadly attentuate to and rounded at apices; eyes rather small, broadly oblong, strongly projecting. Antenna 9- or 10-segmented; first and second segments robust, first long, slightly arcuate, second shorter than first; third to sixth or seventh segments small, compact, transverse except third, united as long as, or shorter than first segment; last three segments forming a large, loose, compressed club, with or without sensory depressions on each surface, the first segment of club transverse, subtriangular, second transversely oblong, and third oblong or oval, narrower than second. Pronotum strongly convex, arcuately emarginate in front, sinuate at base, dentate anteriorly, not transversely depressed behind anterior margin; sides margined along basal half. Scutellum small, quadrate. Elytra strongly convex, with or without tubercles on apical declivity. Legs short, subequal in length; tibia slightly expanded toward apices, slightly dentate on exterior margins, each with a large, arcuate spine at apex; posterior tarsi as long as, or longer than tibiae, apical segment of each shorter than preceding four segments united. Anterior coxae contiguous. Middle coxae narrowly separated. Intercoxal process of abdomen lamellate. Body elongate, cylindrical.

Genotype.-A pate capucinus Fabricius. (Present designation.) 
Lesne (1901) erected Xylopsocus for nine species without designating a genotype.

\section{KEY TO THE SPECIES OF XYLOPSOCUS}

Antenna 9-segmented; apical declivity of elytra densely, coarsely punctate, the elevated lateral margins completely enclosing the declivity; sides of elytra densely punctate or granulose in front of apical declivity capucinus (Fabricius), p. 140.

Antenna 10-segmented; apical declivity of elytra densely, finely granulose, the elevated lateral margin on each side obliterated at anterior third of declivity; sides of elytra transversely rugose in front of apical declivity castanoptera (Fairmaire), p. 141.

\section{Xylopsocus capucinus (Fabricius)}

Apate capucinus Fabricius, 1781, Species Insectorum, v. 1, p. 62; 1787, Mantissa Insect., $\nabla .1$, p. 33.

Synodendron capucinus Fabricius, 1792, Ent. System., v. 1, pt. 2, p. 359.

Sinodendron capucinus Fabricius, 1801, Systema Eleutheratorum, v. 2, p. 378.

Xylopsocus capucinus Lesne, 1901, Soc. Ent. de France Ann. (1900) 69: 628, 631634, figs. 478, 481-482; Fauvel, 1904, Rev. d'Ent. 23: 159; Lesne, 1904, Mission Pavie Indo-Chine, Ent. Div. 3: 106; Jakobson, 1913, Käfer Russland, pt. 10, p. 806 ; Lesne, 1924, Bostrychides de l'Afrique Tropicale Française, pp. 216-217, fig. 133; 1926, Treubia 7: 119; Froggatt, 1927, Forest Insects and Timber Borers, p. 102; Gardner, 1933, Indian Forest Rec., Ent. Ser. 18 (9) : 16-17, pl. 4, figs. 55-56 (larvae) ; Miller, 1934, Straits Settlements and Fed. Malay States, Dept. Agr. Sci. Ser. No. 14, pp. 1, 2, 5, 6, 9, 16-20, pl. 1, figs. 16-19 ; Châjô, 1936, Formosa Nat. Hist. Soc. Trans. 26: 409; Beeson and Bhatia, 1937, Indian Forest Rec., New Ser., Ent. 2: 226, 230, 305-306, 309-320 ; Lesne, 1938, in Junk (pub.), Coleopt. Cat., pt. 161, p. 68.

Bostrichus eremita Olivier, 1790, Encyclopédie Méthodique, Insectes, v. 5, p. 110 ; 1795, Entomologie, v. 4, Gen. 77, pp. 13-14, pl. 2, figs. 11 a, b.

A pate marginata Fabricius, 1,801, Systema Eleutheratorum, v. 2, p. 382.

Enneadesmus nicobaricus Redtenbacher, 1867, Reise der Novara, v. 2, pp. 114-115.

Mate.-Black sometimes with elytra reddish; underside of body, antennae, and palpi reddish brown or brownish yellow.

Head slightly convex, unarmed in front, densely, finely granulose and sparsely clothed with short, recumbent, whitish hairs on front, with fine, longitudinal, parallel costae on occiput; clypeus finely, densely punctate, sparsely clothed with short, recumbent, white hairs; clypeal suture deeply depressed at middle, obsolete at sides. Antennae 9 -segmented, first segment three times as long as second; third to sixth segments united much shorter than first; seventh to ninth segments densely clothed with short, recumbent, yellowish hairs, without distinct sensory depressions, the apical segment oblong.

Pronotum distinctly wider than long, widest behind middle; sides broadly rounded, more strongly converging anteriorly, with a small, unciform tooth at apical angles; posterior angles obtusely angulated; lateral margins sinuate near base; surface glabrous, densely, finely punctate and granulose on basal half, densely, irregularly dentate on apical half, the teeth broad, semierect, variable in size, and rasplike, with a few larger teeth on each side near apical angles.

Elytra at base subequal in width to pronotum behind middle; sides slightly expanded posteriorly, conjointly broadly rounded at apices (angulate when viewed from above); surface glabrous, very densely, finely, uniformly punctate, sometimes confluently punctate and granulose near apical declivity; apical declivity abruptly, obliquely deflexed, flattened, without tubercles or callosities, the lateral margins strongly 
elerated, crenulate toward top of declivity, and completely enclosing the declivity; sutural margins narrow, slightly elerated on apical declivity, strongly elevated at apices.

Abdomen beneath finely, densely granulose, rather densely clothed with short, recumbent, yellowish hairs; first visible sternite longitudinally carinate at middle; last visible sternite not much longer than preceding sternite, and broadly rounded at apex.

Female.-Differs from the male in having the last visible abdominal sternite twice as long as the preceding sternite at the middle, and slightly emarginate at the apex.

Length $3-5.5 \mathrm{~mm}$., width $1.4-1.7 \mathrm{~mm}$.

Type locality.-Of capucinus and eremita, both from the Coromandel Coast, India; type in the Banks Collection in the British Museum. Of marginata. East Indies; location of type unknown to writer. Of nicobaricus, Nicobar Island; type supposed to be in the Vienna Museum.

Distribution.-This species is widely distributed in all tropical regions. It has been recorded from India, Ceylon, China, Siam, IndoChina, Burma, Formosa, Philippines, nearly all Malaysian and Melanesian Islands, Madagascar, etc. It has been introduced from the Indo-Malaysian and Malaccan regions by commerce into the eastern and western coasts of Africa, and French Guinea, Venezuela, Trinidad, and Brazil. Specimens have been intercepted at New York in derris roots from British Malay, and at Miami, Fla., on a plane arriving from Rio de Janeiro, Brazil. So far as known, this species has not become established in the United States.

Hosts. - Faural (1904) stated that it usually lives in mango trees. Lesne (1924) recorded it living in the wood of Morus alba and trunks of "Kimoungoué" in east Africa, in bamboo in Madagascar, in the branches of letchi (Nephelium litchi) in Tonkin, and in the wood of grape in Brazil. Miller (1934) recorded this species as attacking piquia (Caryocar villosum), rambutun (Nephelium lappaceum), rubber (Hevea brasitiensis), Dipterocarpus sp., Derris sp., guava (Psidium guajava), Casuarina equisetifolia, Eugenia malaccensis, cinnamon (Cinnamomum zeylanicum). Indigofera anil, cashew nut (Anacardium occidentale), durian (Durio zibethinus), Tephrosia candida, Gardenia florida, tamarind (Tamarindus indicus), Hibiscus rosa-sinensis, and mango (Mangifera indica). Beeson and Bhatia (1937) recorded it also as attacking Anacardium occidentale, Artocarpus hirsuta, Ficus sp., Mallotus philippinensis, Poinciana elata, Santalum album, Shorea robusta, Sindora siamensis, Swietenia mahogoni, Tectona grandis. Terminolia myriocarpa, and Vitex negundo.

Fabricius (1781) and Olivier (1790) described capucinus and eremita from the same specimen from the Coromandel Coast in the Lanks Collection. The synonymy of marginata Fabricius was made by Lesne (1901) after Meinert compared this specimen with capucinus Fabricius and emarginata Fabricius. Lesne (1901) also placed nicobaricus Redtenbacher as a synonym of capucinus Fabricius.

\section{Xylopsocus Castanoptera (Fairmaire)}

Apate castanoptera Fairmaire, 1850, Rev. and Mag. Zool. (ser. 2) 2: 50.

Xylopsocus castanoptera Lesne, 1901, Soc. Ent. de France Ann. (1900) 69: 629,

$635-636 ; 1926$, Treubia 7: 119; Froggatt, 192 $\tau$, Forest Insects and Timber 
Borers, p. 103 ; Lesne, 1938, in Junk (pub.), Coleopt. Cat., pt. 161, p. 68; Lever, 1945, Bul. Ent. Res. 35 (4) : 375.

Male.-Brown or black, shining; elytra reddish, paler on basal half; antennae, palpi, tarsi, and sides and apex of abdomen, brownish yellow.

Head slightly convex, sometimes slightly, transversely depressed behind eyes, unarmed on front, densely, finely granulose and sparsely clothed with short, recumbent, whitish hairs on front, with fine, longitudinal, parallel costae on occiput; clypeus finely, densely punctate, depressed at middle along posterior margin; clypeal suture depressed at middle, obsolete at sides. Antenna 10-segmented; first segment twice as long as second; third to seventh segments united as long as, or longer than first; eighth to tenth segments sparsely clothed with short, recumbent, yellowish hairs, with distinct, round, sensory depressions on each surface, the apical segment oval.

Pronotum distinctly wider than long, widest at basal third; sides broadly rounded, more strongly converging anteriorly, with a small, unciform tooth at apical angles; posterior anglês obtusely angulated; lateral margins arcuate, not sinuate near base; surface glabrous, impunctate at sides on basal half, sparsely, finely, irregularly punctate on median part of basal half, densely, irregularly dentate on apical half, the teeth broad, semierect, variable in size, and rasplike, with a few larger teeth on each side near apical angles.

Elytra at base subequal in width to pronotum at basal third; sides slightly expanded posteriorly, conjointly broadly rounded at apices; surface glabrous, finely, densely punctate on basal half, transversely rugose at sides near apical declivity, densely, finely granulose on apical declivity; apical declivity abruptly, obliquely deflexed, flattened, without tubercles or callosities, the lateral margins strongly elevated posteriorly, but obliterated on inner third of declivity; sutural margins strongly, narrowly, uniformly elevated on apical declivity.

Abdomen beneath finely, densely punctate, densely clothed with rather long, recumbent, whitish hairs; first visible sternite longitudinally carinate on anterior half; last visible sternite broadly rounded at apex.

Female.-Similar to the male except that the last visible abdominal sternite is vaguely emarginate at the apex.

Length 3-4.5 mm., width 1.4-1.6 mm.

Type locality.-Tahiti; type probably in the Paris Museum.

Distribution.-This species has been recorded from Madagascar, German East Africa, Assam, Annam, Comores, Borneo, New Guinea, Indo-China, Australia, Tahiti, Fiji, and the Maurice Islands. Specimens were intercepted at New York, April 13, 1939, in Cryptocarya palmerstoni logs from Australia, but so far as known, has not become established in the United States.

Hosts.-Fairmaire (1850) described this species from material collected on Hybiscus tiliacea, and Lever (1945) recorded it as attacking the trunks and branches of cocoa (Theobroma cacao) in Fiji.

Lesne (1901) places affinis Brancsik ${ }^{11}$ as a synonym of catanoptera. The writer has not seen the description of affinis.

\footnotetext{
${ }^{11}$ BRANCSIK, C. BEITRÄGE ZUR KENTNISS NOSSIBÉS UND DESSEN FUANA NACH SENDUNGEN, UND MITTHEILUNGEN DES HERN P. FREY. Jahrb. der Naturw. Ver. des Trencsin. Comil. $15: 235,1893$.
} 


\section{ADDENDA}

The following genus does not occur in North America, but several North American species have erroneously been placed in it. They are now placed in Xyloperthella, new name.

\section{Genus XILOPERTHA Guérin-Ménéville}

Xylopertha Guérin-Ménérille, 1845, Soc. Ent. de France Ann. (ser. 2) 3: Bul. p. XVII.

Iylonites Lesne, 1901, Soc. Ent. de France Ann. (1900) 69: 478, 575-ð\$4; 1938, in Junk (pub.), Coleopt. Cat., pt. 161, p. 65. (New synonymy.)

Genotype.-Of Xylopertha, A pate sinuata Fabricius. (Designated by Gorham.) Of Xylonites, Bostrichus retusus Olivier. (Present designation.)

Guérin-Ménéville described Xylopertha in a table for separating genera, and in a footnote gives as the types A pate minutus Fabricius, truncata Dejean, longicornis Fabricius, sinuata Fabricius, etc., without designating a genotype. A pate truncata is a nomen nudum, A pate minuta belongs to Dinoderus Stephens, and Bostrichus longicornis has now the genus Tetrapriocera for its reception. Gorham ${ }^{12}$ designated A pate sinuata Fabricius as the genotype of Xylopertha Guérin-د Iénéville.

Lesne (1901) apparently overlooked the designation of sinuata as the type of Xylopertha, and erected Xylonites for three species, including retusus Olivier (sinuatus Fabricius) without designating a genotype. Xylonites Lesne (1901) must be suppressed as a synonym of Xylopertha Guérin-Ménéville (18t5).

${ }^{13}$ Gorham, H. S. Mala codermata. Biol. Centr.-Amer., Coleopt., г. 3, pt. 2, p. $215,1883$. 



\section{INDEX TO SPECIES}

[Valid names are in roman type, synonyms in italics.]

Acrepis LeConte aequalis Waterhouse [Bostrichus] aequalis (Waterhouse) [Hetero-
bostrychus] Alloeocnemis LeConte........ Amphicerus LeConte . . . 54, 56, aspericollis (Germar) ....... bicaudatus (Say) ......... bicornutus (Latreille) _...... 68, 70 bimaculatus (Olivier) _.. 67, 68, 72 brevicollis Casey _._._._._. 74 cornutus (Pallas) _._._._. 68, 70, 71 fortis LeConte. . . . gracilis Casey............ grandicollis Casey ......... hamatus Lesne, not Fabricius................... maritimus Casey .......... migrator (Sharp) ......... peregrinus (Erichson) ...... punctipennis (LeConte) .... serricollis (Germar) ........ simplex (Horn)

teres Horn amplus Casey [Dinoderus] ...... amplus (Casey) [Stephanopachys] _. anale Lesne [Sinoxylon] angustatus (Casey) [Lichenophanes]

anobioides Waterhouse [Caenophrada] . . . . . . . . . . . . .

Anobium Fabricius.......... reticulatus Herbst

Apate Fabricius aspericollis Germar....... basalis Dejean........... basilaris Say _._._._._._. 12 bicaudatus Say. bicornis Weber............ bidens Fabricius......... bimaculatus (Olivier) . . - . capillata Dejean -........ capucinus (Fabricius) chevrieri Villa cornutus (Olivier) destructor Burchell.......... destructor Montrouzier..... dominica Fabricius........ elongatus Paykull......... femoralis Fabricius........ flavipes Illiger 135,136
Page
Apate Fabricius-Continued humeralis Melsheimer...... 122 lifuana Montrouzier...... 138 marginata Fabricius._._._. 140 minutus Fabricius..... 25, 30, 143 punctatus (Say) _..._._._. 36, 37 punctipennis LeConte..... 70 pusilla Fairmaire, not Fab-

ricius_............. 35 religiosa Boisduval_..... 135, 138 rufa Hope............. 35 rufescens Dejean........ 102 serricollis Germar......... 68 sexdentatum Olivier....... 63 sinuata Fabricius_.....-. 143 sinuata Stephens, not Fabricius - . - . - 136 substriatus Paykull_._._ 24, 42, 45 tetraodon Fairmaire _..... 98 torquata Fabricius_._._. 119, 120 tridens Fabricius, not Lesne $1901 \ldots \ldots$ truncata Dejean....... 143 varia Illiger_.......... 76 xyloperthoides JacquelinDuval_........... 89 Apate Redtenbacker......... 54 Apatides Casey_........._._. 54, 95 fortis (LeConte) _...... 96 pollens Casey _..._._._._. 96 puncticeps Casey......... 96 robustus Casey_......... 96 A patodes Blackburn......... 57 macleayi Blackburn_...... 57, 58 apax Lesne [Prostephanus] _..._. 37, 40 Apoleon Gorham ......... 3, 3 Apoleoninae Gardner........ 3 arcellata Lesne [Xyloprista] _...- 118 arizonicus, n. sp. [Lichenophanes] 76,77 arizonicus, n. sp. [Prostephanus] _ 36, 38 arizonica Lesne [Scobicia] _. _. 105, 109 armiger LeConte [Bostrichus] _..- $\quad 79$ armiger (LeConte) [Lichenophanes]__............. 76, 79 aspera (LeConte) [Dendrobiella] 128 aspericollis Germar [Apate] _..._. 67,68 aspericollis (Germar) [Amphicerus]_..._._. asperulus Casey [Dinoderus] ....- 47 asperulus (Casey) [Stephanopachys]_... . asperum LeConte [Sinoxylon] .... 128 barbata (Wollaston) [Scobicia]_ 105, 113 barbata (Wollaston) [Xylopertha] 
barbatus Wollaston [Enneadensmus]

basalis Dejean [Apate] basalis (Dejean) [Xylobiops].... basilare (Say) [Sinoxylon] ...... basilaris Say [Apate] _ _. _ _ _ 122, basilaris (Say) [Xylobiops] ...... bevani Curtis [Exops] ......... bevani (Curtis) [Polycaon] bicaudatus Say [Apate] bicaudatus (Say) [Amphicerus] . bicaudatus (Say) [Bostrichus] ...bicornis Weber [Apate] ....... bicornis (Weber) [Bostrichus] bicornis (Weber) [Lichenophanes] bicornutus Latreille [Ligniperda] bicornutus (Latreille) [Amphicerus]

bidens Fabricius [Apate] bidens (Fabricius) [Sinoxylon]... bidentata Horn [Sinoxylon] bidentata (Horn) [Scobicia] ---

bidentata (Horn) [Xylopertha] bidentata Lesne, not Horn [Scobicia]-

bifoveolata Wollaston [Rhyzopertha]

bifoveolatus (Wollaston) [Dinoderus]

bifoveolatus Zoufal, not Wollaston [Dinoderus].

bilobata, n. sp. [Micrapate] bimaculatus Olivier [Bostrichus]. bimaculatus (Olivier) [Apate] _..bimaculatus (Olivier) [Amphicerus]

bimaculatus (Olivier) [Schistoceros]

Bostrichinae

Bostrichini

Bostrichus Geoffroy _........... aequalis Waterhouse...... angustatus Casey .......... armiger LeConte.......... bicaudatus (Say) .......... bicornis (Weber) .......... bimaculatus Olivier. brunneus Murray........... californicus Horn capucinus (Linnaeus) var. luctuosus Olivier . cornutus Olivier cornutus (Pallas) eremita Olivier............. fasciculatus Fall femoralis (Fabricius) ....... grayanus Wollaston....... longicornis Olivier. 102, 103 migrator Sharp.......... minutus (Fabricius) $\ldots . . .$. mutilatus Walker......... parallelus Lesne [Bostrychus]_................. peregrinus Erichson piceus Olivier.
Page

113

123

123

122

22,123

122

11

11

67,68

67,68 68

76,78

70

68,70

63

107

104

105, 107

107

106

30 88,94

67,72

72

54,75

85

82

79

68

78

67,72

83

80

55

56

65

70

140

76

6

84

103
70

30

136

98, 99

70

116
Bostrichus Geoffroy-Continued picipennis Fahraeus....... punctipennis LeConte.....retusus Olivier............. rugosus Olivier scabratus Erichson sexdentatum Olivier....... spectabilis Lesne......... tetraodon Fairmaire...... truncaticollis LeConte..... uncipennis Lesne......... vertens $\mathrm{W}^{\top}$ alker vitis Blanchard......... xyloperthoides (JacquelinDuval)

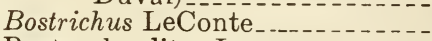

Bostrychoplites Lesne..... cornutus (Olivier) destructor (Burchall)

Bostrychopsis fortis (LeConte) parallela (Lesne) tetraodon (Fairmaire) _.... 98, 99

Bostrychulus Lesne.......... 87, 88 brasiliensis Lesne_._._.... 92 dinoderoides Lesne, not Horn_... 87, 93 scabratus (Erichson) xyloperthoides (JacquelinDuval)

Bostrychus_................ 54

brasiliensis Lesne [Bostrychulus]. brasiliensis (Lesne) [Micrapate]_ 88, 92 brevicollis Casey [Amphicerus]_- 74 brevicollis (Casey) [Schistocerus]. brevis Horn [Dinoderus] brevis (Horn) [Patea] brunneus Murray [Bostrichus].brunneus (Murray) [Heterobostrychus] Caenophrada Waterhouse..... anobioides Waterhouse californicus Horn [Bostrichus].californicus (Horn) [Lichenophanes]_........ capillata Dejean [Apate] capillata Dejean [Scobicia] capucinus Fabricius [Synodendron] _.................. capucinus (Fabricius) [Apate]-

capucinus (Fabricius) [Xylopsocus]_._. 140 capucinus Linnaeus [Dermestes] $\quad 55$ capucinus (Linnaeus) [Ligniperda]

capucinus (Linnaeus) [Bostrichus]_.................. var. luctuosus Olivier [Bostrichus]

capucinus (Linnaeus) [Apate] -. 55 carinatus Guerin-Meneville [Exo-. pioides]

carinatus Guerin-Meneville [Melalgus]_........... castanoptera Fairmaire [Apate]--
89

Page

84

67

43

2

24,27 
castanoptera (Fairmaire) [Xylopsocus]

chevrieri Villa [Apate]

140,141

chevrieri (Villa) [Scobicia]_ 104, 105, 112 chevrieri (Villa) [Xylopertha] ... chiliensis Castelnau [Polycaon]. . chiliensis Erichson [Psoa] chiliensis Erichson [Polycaon] - chiliensis Lacordaire [Melalgus] -

Cis Latreille

rugosus Dejean ..........

cleroides Lesne [Psoa]

cleroides Lesne [Acrepis] ........ confertus LeConte [Polycaon] confertus (LeConte) [Melalgus] . confertus (LeConte) [Heterarthron]_................. conicola, n. sp [Stephanopachys]_ 43, 48 conigerum Gerstacker [Sinoxy-

lon]

cornuta Pallas [Ligniperda] ..... cornutus Olivier [Bostrichus] ... cornutus Olivier [Apate] ........ cornutus Olivier [Bostrychoplites]_-
cornutus (Pallas) [Amphicerus] _- (Pallas) [Bostrichus] _cornutus (Pallas) [Schistoceros] cribratus LeConte [Dinoderus].. cribratus (LeConte) [Stephanopachys] crinitarsis Imhoff [Xylopertha] crinitarsis (Imhoff) [Xyloperthella] _................ cristicauda Casey [Micrapate] _.

cylindricus Dejean [Melalgus] _. declivis LeConte [Sinoxylon] ... declivis (LeConte) [Scobicia] ... -

declivis (LeConte) [Xylopertha]

Dendrobiella Casey......... 101, 127 aspera (LeConte) pubescens Casey quadrispinosus (LeConte). 128, 132 sericans (LeConte) ........ sericans Casey, not LeConte. densus LeConte [Dinoderes] ... . densus (LeConte) [Stephanopachys]................ Dermestes capucinus Linnaeus....... destructor Burchell [Apate] ...... destructor (Burchell) [Bostrychoplites]_-............... destructor Montrouzier [Apate] . destructor (Montrouzier) [Xylothrips]

Dictyalotus Redtenbacher...... reticulatus (Herbst)

Dinapate Horn

Din wrightil Horn

Dinapatinae Lesne

20,23
Dinapatini Lesne..............

Dinoderastes Lesne ...........

Dinoderidae Lesne.............

Dinoderina Schilsky . . . . . . . . .

Dinoderinae Lesne...........

Dinoderini Lesne............

dinoderoides Horn [Sinoxylon] - dinoderoides (Horn) [Micrapate][Bostrychulus]_........... 87, 93 dinoderoides Lesne, not Horn [Micrapate] Dinoderopsis Lesne _........... 23 Dinoderus Stephens........ 23, 24, 42 amplus Casey..._._._._. 44 asperulus Casey bifoveolatus (Wollaston) _. 25, 32 bifoveolatus Zoufal, not Wollaston brevis Horn ........... 25, 27 cribratus LeConte........ 49 densus LeConte......... 50 hispidulus Casey........ 50 japonicus Lesne_......... 25 japonicus Matsumura, not Lesne _............... minutus (Fabricius) _..... 25, 30 nitidus Lesne .......... 27 ocellaris Stephens . . . _ 24, 25, 28 opacus Casey . . . . . . pacificus Casey.......... 45 parvulus (Casey) _..._.... 50 perpunctatus Lesne....... 32 pilifrons Lesne_........... 28 porcatus LeConte_._._._. 43 pubicollis Van Dyke punctatus (Say) .......... pusillus Horn, not Fabricius. sicula (Baudi) ............ sobrinus Casey ............. substriatus (Paykull) ...... substriatus Stephens, not Paykull_.......... 30 30, 42, 45 truncatus (Horn) _._._._. _ 39 tsugae Matsumura........ 25 vertens (Walker) _........ 30

Dinoderus Guérin-Ménéville, not Stephens . . . . . . . . dominica Fabricius [Synodendron] _................ dominica (Fabricius) [Rhyzopertha] dominica Fabricius [Apate] _... dominicana (Fabricius) [Xylopertha] dominicanus (Fabricius) [Xylothrips] _. dorsalis Mellié [Endecatomus]_-_ 20, 21 Dysides Perty . . . . . . . . . . 3 obscurus Perty $\ldots \ldots \ldots$ Dysididae Lesne_.......... 2,3 Dysidinae Lesne __
elongatus Paykull [Apate] _. _ _

51 Endecatominae _......... 2, 4, 19

51 Endecatomini LeConte....... 19 
Endecatomus Mellié........... dorsalis Mellié lanatus Lesne ............ reticulatus Melsheimer, not Herbst ............. rugosus (Randäll) ......... 19,21

Enneadesmus Mulsant_....... 113, 140 barbatus Wollaston....... nicobaricus Redtenbacher... espisternalis Lesne [Octodesmus]. eremita Olivier [Bostrichus] ..... eremita Olivier [Xylopsocus] .... exesus LeConte [Exops]

exesus (LeConte) [Heterarthron] exesus (LeConte) [Melalgus] exesus (LeConte) [Polycaon] .... Exopioides Guérin-Ménéville.... carinatus Guérin-Ménéville. incisa LeConte.......... Exops Curtis

bevani Curtis............ exesus LeConte. ovicollis LeConte. stoutii (LeConte)

fasciculatus Fall [Bostrichus] fasciculatus (Fall) [Lichenophanes]

femoralis Fabricius [Apate] femoralis(Fabricius) [Bostrichus]. femoralis (Fabricius) [Heterarthron]

femoralis (Fabricius) [Melalgus]femoralis Lesne, not Fabricius [Heterarthron] ............. fissicornis Marsham [Ptinus] ...fissicornis (Marsham) [Rhyzopertha] _.............. flavipes Illiger [Apate]-_-_. 135, flavipes (Illiger) [Xylothrips]
floridanum Horn [Sinoxylon] - . floridanus (Horn) [Xylobiops].-floridanus (Horn) [Xylomeira] ... fortis LeConte [Amphicerus].... fortis (LeConte) [Apatides] ..... fortis (LeConte) [Bostrychopsis] foveicollis Allard [Xylopertha]... foveicollis (Allard) [Scobicia].... geminatum Schilsky [Sinoxylon]. gonagra (Fabricius) [Melalgus] gonagra (Fabricius) [Heterarthron] gracilis Casey [Amphicerus]...grandicollis Casey [Amphicerus]. grandicollis (Casey) [Schistoceros] granulatus Van Dyke [Polycaon]. grayanus Wollaston [Bostrichus]. grayanus (Wollaston) [Heterobostrychus]

hamatus Lesne, not Fabricius [Schistoceros] . ............. hamatus (Lesne, not Fabricius) [Amphicerus] .............. Hendecatomidae Kiesenwetter.. Hendecatominae Lesne..........

\section{Page}

19

20, 21

20

20,22

140

140

115

140

140

7

7,11

11

13

13

76

76

10

6

136

120

120

120
Hendecatomus Bach............ reticulatus (Melsheimer)_-..-
Heterarthron Dejean_......... 3, confertus (LeConte) ....... exesus (LeConte) femoralis (Fabricius) femoralis Lesne, not Fabricius. gonagra (Fabricius) megalops (Fall) . . . . . . parvulum Lesne.......... plicatus (LeConte) . . . . .

Heterobostry chus Lesne........ aequalis (Waterhouse) ..... brunneus (Murray) grayanus (Wollaston) ...... picipennis (Fahraeus) ...... uncipennis (Lesne) ....... hexacantha Fairmaire [Xylopertha]

hexacantha (Fairmaire) [Xyloprista] . . . . . . . hispidulus Casey [Dinoderus] ... hispidulus (Casey) [Stephanopachys] humeralis Melsheimer [Apate]--
humeralis (Melsheimer) [Xylobiops] incisa LeConte [Exopioides].... incisa (LeConte) [Melalgus] ...japonicum Lesne [Sinoxylon]_- 58,61 japonicus Lesne [Dinoderus].... japonicus Matsumura, not Lesne [Dinoderus] labialis Lesne [Micrapate] _.. 88,94 lanatus Lesne [Endecatomus]-- 20 lesnei, n. sp. [Scobicia]_._.... 105 Lichenophanes Lesne _........ 54, 75 angustatus (Casey) -...... arizonicus, n. sp........... armiger (LeConte) bicornis (Weber) californicus (Horn) fasciculatus (Fall) ....... mutchleri Belkin _......... spectabilis (Lesne) truncaticollis (LeConte) .... varia (Illiger) _.......... lifuana Montrouzier [Apate] ....lifuana (Montrouzier) [Xylopertha] lifuana (Montrouzier) [Xylothrips] 138 Ligniperda Pallas_..._....... _ 55, 70 bicornutus Latreille........ 70 capucinus (Linnaeus) cornuta Pallas . . . linearis Kugelann [Stephanopachys]_... longicornis Olivier [Bostrichus] 102, 103 longicornis (Olivier) [Xylopertha] . longicornis (Olivier) [Tetrapriocera]__._._. _._._._. 102, 121 Lyctidae_................... 2 macleayi Blackburn [Apatodes]_- 57,58 
macleayi (Blackburn) [Sinoxylon] maculata LeContata (LeConte) [Psoa] .... marginata Fabricius [Apate] marginata (Fabricius) [Xylopsocus]

maritimus Casey [Amphicerus] - megalops Fall [Polycaon]....... megalops (Fall) [Heterarthron] megalops (Fall) [Melalgus] _..... Melalgus Dejean _............. carinatus (Guérin-Ménéville) chiliensis Lacordaire. confertus (LeConte) . . . . . . cylindricus Dejean_......... exesus (LeConte) femoralis (Fabricius) _....... gonagra (Fabricius) incisa (LeConte) ......... megalops (Fall) .......... obliquus (LeConte) ........ parvulus (Lesne) ........... plicatus (LeConte)

mexicana, n. sp. [Micrapate] -.. Micrapate Casey ............ bilobata, n. sp . . . . . . . . . brasiliensis (Lesne) - ...-.-cristicauda Casey dinoderoides (Horn) . . ..... labialis Lesne ............. mexicana, n. sp .......... scapularis Gorham scrabata (Erichson) simplex (Horn) vitis (Blanchard) .......... xyloperthoides (JacquelinDuval) migrator Sharp [Bostrichus] migrator (Sharp) [Amphicerus] . minutus Fabricius [Apate] minutus (Fabricius) [Bostrichus] minutus (Fabricius) [Dinoderus] minutus (Fabricius) [Xylopertha] _..... 143 monticola, n. sp. [Scobicia] __ _ 105, 108 muricatum Fabricius [Sinoxylon] muricatum Fabricius [Synodendron]

mutchleri Belkin [Lichenophanes] mutilatus Walker [Bostrichus] _.. mutilatus (Walker) [Xylothrips] _. nicobaricus Redtenbacher [Enneadesmus]

nicobaricus (Redtenbacher) [X $\mathrm{X}$ lopsocus]

nitidus Lesne [Dinoderus] obliquus LeConte [Polycaon].... . obliquus (LeConte) [Melalgus] ... obscurus Perty [Dysides] ........ ocellaris Stephens [Dinoderus]. 24, 25, 28 Octodesmus Lesne........... 101, 114 episternalis Lesne......... parvulus (Lesne)
Page opacus Casey [Dinoderus]

Page

43

43

13

13

45

45

96

87 parallelus Lesne [Bostrichus]__._ 98, 99 tha] _.................... parallelus (Lesne) [Bostrychopsis] _ _ _ parilis Lesne [Xylobiops] . . . _ 122, 124 parvulus Lesne [Heterarthron] _- 10 parvulus (Lesne) [Melalgus]_._. 10 parvulus Casey [Dinoderus]..... 50 parvulus (Casey) [Stenphanopachys]

parvulus Lesne [Xylopertha] ... parvulus (Lesne) [Octodesmus].Patea Casey . . . . . . . . . . brevis Horn peregrinus Erichson [Bostrichus] peregrinus (Erichson) [Amphicerus] -1 (Erichson) [Schistoperegrinus (Erichson) [Schisto-
ceros] perpunctatus Lesne [Dinoderus] piceus Marsham [Ptinus]........ piceus (Marsham) [Rhyzopertha] piceus Olivier [Bostrichus] ...... piceus (Olivier) [Xylopertha] ... piceus (Olivier) [Xyloperthella] picipennis Fåhraeus [Bostrichus] picipennis (Fåhraeus) [Heterobostrychus].

pilifrons Lesne [Dinoderus] ..... plicatus LeConte [Polycaon] ... 7 plicatus (LeConte) [Heterarthron] plicatus (LeConte) [Melalgus] - $\quad 6,7$ pollens Casey [Apatides] _..._. 96 Polycaon Castelnau__._._. 5, 6, 11, 19 brevani Curtis_........... 11 chiliensis Castelnau...... 11 confertus LeConte........ 9 exesus (LeConte) granulatus Van Dyke..... 12 megalops Fall_......... 10 obliquus LeConte......... 7 ovicollis (LeConte) plicatus (LeConte) pubescens LeConte........ 12, 14 punctatus LeConte _....... 12, 14 stoutii (LeConte) ..... 11, 12, 13 Polycaoninae Lesne........... 5 Polycaonini Lesne........... 2, 5 porcatus LeConte [Dinoderus] _- 43 porcatus (LeConte) [Stephanopachys]

praemorsa Erichson [Xylopertha] praemorsa) Erichson ([Xyloprista] 
Page

prosopidis, n. sp. [Xyloblaptus]

Prostephanus Lesne........... apax Lesne .............. arizonicus, n. sp_......... punctatus (Say) sulcicollis (Fairmaire and
Germain) truncatus (Horn) 37 ,

Psoa Herbst cleroides Lesne. maculata (LeConte) quadrisignata (Horn) . . . . _ sexguttata Lesne. viennensis Herbst

Psoa Erichson, not Herbst. chiliensis

Psoidae Böving and Craigh-Psoina Jakobson

Psoinae Lesne

Psoini LeConte.

Ptinus Linnaeus piceus Marsham

pubescens Casey [Dendrobiella]_ 128,129 pubescens LeConte [Polycaon] -. pubescens Murray [Sinoxylon] -pubescens (Murray) [Xylopertha] pubescens (Murray) [Xyloperthellaj. pubicollis Van Dyke [Dinoderus] punctatus LeConte [Polycaon] punctatus Say [Apate] _....... punctatus (Say) [Dinoderus] -.. punctatus (Say) [Prostepha-

nus] _. . punctatus (Say) [Stephanopachys]

puncticeps Casey [Apatides]...punctipennis LeConte [Apate] ... punctipennis (LeConte) [Amphicerus]

punctipennis (LeConte) [Bostrichus]

pusilla (Fabricius) [Apate]..... pusilla (Fabricius) [Rhyzopertha]

pusillum Fabricius [Synodendron]

pusillus (Fabricius) [Dinoderus] pustulata Kiesenwetter [Xylopertha]

pustulata (Kiesenwetter) [Scobicia]

quadricollis Marseul [Stephanopachys]_............... quadrisignata Horn [Acrepis] quadrisignata (Horn) [Psoa] _... 16, 17 quadrispinosus LeConte [Sinoxylon] quadrispinosus (LeConte) [Dendrobiella]_............ 128, 132 quadrispinosus (LeConte) [Xyloblaptus]_. . . . . . _... 131, 132 quadrispinosus (LeConte) $[\mathrm{Xy}-$ lopertha].....................
131 religiosa Boisduval [Apate] _._ 135, 138 23, 36 religiosa (Boisduval) [Rhyzoper37,40 tha] _................ 36,38 religiosa (Boisduval) [Xylopertha] _..... 138 religiosae Fairmaire [Apate]

robustus Casey [Apatides] rufa Hope [Apate]........... rufa (Hope) [Rhyzopertha] ..... rufescens Dejean [Apate] ....... religiosae (Fairmaire) [Xylothrips]_........... 136 religiosus (Biosduval) [Xylothrips]_............ 135, 138 reticulatum Herbst [Anobium]__ 20 reticulatus (Herbst) [Dictyalotus] Melsheimer, not Herbst [Endecatomus] reticulatus (Melsheimer) [Hendecatomus] retusus Olivier [Bostrichus] retusus (Olivier) [Xylonites] .... Rhizopertha Guérin-Ménéville.-Rhizoperthodes Lesne......... Rhyzopertha Stephens._...... dominica (Fabricius) fissicornis (Marsham) papuensis MacLeay _........ piceus (Marsham) _....... pusillum (Fabricius) ....... religiosa (Boisduval) _...... rufa (Hope) . . . . . . . . . sicula Baudi ............ vitis (Blanchard) ......... refescens (Dejean) [Tetrapriocera] 102 ruficorne Fåhraeus [Sinoxylon] _ 58, 62 rugosus Dejean [Cis]_......... 21 rugosus Randall [Triphyllus] _... 21

rugosus (Randall) [Endecatomus] 19, 21 rugosus (Randall) [Hendecatomus]__._............ 22

rugosus Olivier [Bostrichus] _... 43 rugosus (Olivier) [Stephanopachys].

scabrata (Erichson) [Micrapate] 88,93 scabratus Erichson [Bostrichus]_- 90 scabratus (Erichson) [Bostrychulus]_._._._. 90 scapularis Gorham [Xylopertha] $\quad 94$ scapularis (Gorham) [Micrapate] 94 Schistoceros Lesne_......... 66, 68 brevicollis (Casey) _...... 74 bimaculatus (Olivier) cornutus (Pallas) grandicollis (Casey) hamatus Lesne, not Fabricius peregrinus Erichson.....-- 70 simplex Horn _.......... 74 teres Horn schwarzi Horn [Tetrapriocera] - 102 Scobicia Lesne_........... 101, 104 arizonica Lesne_........ 105, 109 barbata (Wollaston) ..... 
Scobicia Lesne-Continued bidentata Lesne, not Horn bidentata (Horn) _... 104, 105, 107 capillata Dejean _........... 112 chevrieri (Villa)_.... 104, 105, 112 declivis (LeConte) _. _ 104, 105, 110 foveicollis (Allard) monticola $\mathrm{n}$ sp pustulata (Kiesenwetter) suturalis (Horn)

104, 105

112 scutula Lesne [Xylopertha] ..... scutula (Lesne) [Xyloperthella] securifer Lesne [Xylion] ......... sericans LeConte [Sinoxylon].... sericans (LeConte) [Dendrobiella] sericans (LeConte) [Xylopertha]_ sericans Horn, not LeConte [Sinoxylon]

sericans Casey, not LeConte [Dendrobiella]

serricollis Germar [Apate] serricollis (Germar) [Amphicerus] sexdentatum Olivier [Bostrichus] sexdentatum (Olivier) [Apate] .. sexdentatum (Olivier) [Sinoxsexguttata Lesne [Psoa] .......... sexguttata (Lesne) [Acrepis]...... sextuberculatum LeConte [Sinoxvlon] sextuberculatus (LeConte) [Xylobiops] sextuberculatum Gorham, not LeConte [Xvlopertha] sextuberculatum (Gorham, not LeConte) [Xrlomeira]_....... sicula Baudi [Rhyzopertha]..... sicula (Baudi) [Dinoderus]...... simplex Horn [Sinoxylon] ...... simplex (Horn) [Amphicerus] ... simplex (Horn) [Micrapate] .... simplex (Horn) [Schistoceros] ... Sinoxylon Duftschmid........ anale Lesne. asperum I Conte-....... basilare (Say) bidens (Fabricius) ......... bidentata Horn ........... conigerum Gerstacker declivis LeConte.......... dinoderoides Horn ......... floridanum Horn.......... geminatus Schilsky. japonicum Lesne...... macleayi (Blackburn)

muricatum (Fabricius) pubescens Murray _........ quadrispinosus LeConte_- 131 ruficorne Fåhraeus sericans LeConte.......... sericans Horn, not LcConte. sexdentatum (Olivier) _.- 57 , sextuberculatum LeConte. simplex Horn suturalis Horn texanus Horn
116

116

104

129

129

129

128

128

68

68

57,63 58, 63 sinuata Fabricius [Apate] sinuata (Fabricius) [Xylopertha]

sinuata Stephens, not Fabricius [Apate]. sinuata (Stephens, not Fabricius) [Xrlothrips].

sobrinus Casey [Dinoderus] sobrinus (Casey) [Stephanopachys]_.................. 43, 47 spectabilis Lesne [Bostrychus]_.. $\quad 77$ spectabilis (Lesne) [Lichenophanes]_.................... 76, 77 Stephanopachys Waterhouse _.. 23, 42 amplus (Caser) _.......... 43, 44 asperulus (Casey) _....... 43,47 conicolor, n. sp_....... 43,48 cribratus (LeConte) _. . . . _ 43, 49 densus (LeConte) ....... 43, 50 hispidulus (Casey) _....... 43, 50 linearis Kugelann_....... 25 opacus (Casey) pacificus (Casey) _....... 45 parvulus (Casev) _...... 50 porcatus (LeConte) punctatus (Say) _.......... 37 quadricollis Narseul_..... 43 rugosus (Olivier) ......... 43 sobrinus (Casey) _....... 43,47 substriatus (Paykull) _.. 42, 43, 45 truncatus (Horn) _......... 39 stoutii LeConte [Alloeocnemis] _. 11, 13 stoutii (LeConte) [Exops]_..... 13 stoutii (LeConte) [Polycaon] $-11,12,13$ substriatus Paykull [Apate]_- 24, 42, 45 substriatus (Paykull) [Dinoderus] 24, 45 substriatus (Paykull) [Stephano-

pachys]_.............. 42, 43, 45 substriatus Stephens, not Paykull

[Dinoderus]_.............. 30, 42 sulcicollis Fairmaire and Germain

[Xylopertha] ............... sulcicollis (Fairmaire and Germain) [Prostephanus]

suturalis Horn [Sinoxylon] .... 105 suturalis (Horn) [Scobicia] _... 104, 105 suturalis (Horn) [Xylopertha]_.. 105 Synodendron Fabricius_........ 34 capucinus Fabricius._._... 34, 140 dominicum Fabricius ...... 34 muricatum Fabricius _..... 57 pusillum Fabricius teres Horn [Amphicerus]_..... 68, 73 teres (Horn) [Schistoceros]_..... 73 tetraodon Fairmaire [Apate] _... 98 tetraodon (Fairmaire) [Bostrichus]_................ 98 tetraodon (Fairmaire) [Bostrychopsis]_............... 98 Tetrapriocera Horn _..... 101, 102 longicornis (Olivier) _.... 102, 121 rufescens (Dejean)_....... 102 schwarzi Horn_.......... 102 tridens Lesne, not Fabricius_ 102 texanus Horn [Sinoxylon]_..... 125 texanus (Horn) [Xylobiops] _. 122, 125 
torquata Fabricius [Apate] ---torquata (Fabricius) [Xylomeira] tridens Fabricius [Apate] tridens (Fabricius) [Xylomeira] tridens Lesne, not Fabricius [Tetrapriocera]

Triphyllus Latreille............. rugosus Randall.......... truncata Dejean [Apate] truncata (Dejean) [Xylopertha]truncaticollis LeConte [Bostrichus] truncaticollis (LeConte) [Lichenophanes]

truncatus Horn [Dinoderus] truncatus (Horn) [Prostephanus]

truncatus (Horn) [Stephanopachys]_................ Trypocladus Guérin-Ménéville_-tsugae Matsumura [Dinoderus].uncipennis Lesne [Bostrichus]... uncipennis (Lesne) [Heterobos-trychus].

varia Illiger [Apate] varia (Illiger) [Lichenopachys] vertens Walker [Bostrichus]..... vertens (Walker) [Dinoderus].... viennensis Herbst [Psoa] ...... vitis Blanchard [Bostrichus] ....vitis (Blanchard) [Micrapate]... vitis (Blanchard) [Rhyzopertha] wrightii Horn [Dinapate] Xylion Lesne..... 101, 133 securifer Lesne............ 134

Xylobiops Casey basalis (Dejean) _......... basilaris (Say) _.......... floridanus (Horn) humeralis (Melsheimer) ... parilis Lesne_........... 122, 124 sextuberculatus (LeConte) ..

texanus (Horn)

123

122

120

123

122 ,

126 prosopidis, n. sp. quadrispinosus (LeConte) - 131, 132

Xylomeira Lesne_........... 101, 119 floridanum (Horn) ........ sextuberculata (Gorham, not LeConte) torquata (Fabricius) tridens (Fabricius) .........

Xylonites Lesne................... retusus Olivier

Xylopertha Casey, not GuérinMénéville.

Xylopertha Guérin-Ménéville. 116 barbata (Wollaston) _...... bidentata (Horn) chevrieri (Villa) _........... 19,120 104 113 107
119

xyloperthoides Jacquelin-Duval [Apate] xyloperthoides (Jacquelin-Duval) [Bostrichus] ............. xyloperthoides (Jacquelin-Duval)

[Bostrychulus] -......... xyloperthoides (Jacquelin-Duval)

[Micrapate] Xyloprista Lesne_.......... 101, 117 arcellata Lesne_........... 118 hexacantha (Fairmaire) _.. 118 praemorsa (Erichson) _.... 118 Xylopsocus Lesne._._..... 101, 139 capucinus (Fabricius) _... 139,140 castanoptera (Fairmaire) _ 140, 141 eremita (Olivier) _..._._._. 140 marginata (Fabricius) _..... 140 nicobaricus Redtenbacher..- 140 120 143 143 143 112
Xylothrips Lesne____._._._- 101, 135 destructor (Montrouzier) _..- 138 dominicanus (Fabricius) _..- 136 flavipes (Illiger) _..._._._ 135, 136 lifuana (Montrouzier) mutilatus (Walker) religiosus (Boisduval) sinuata (Stephen, not Fabricius) _ 136 religiosae (Fairmaire) 


\section{INDEX TO HOST PLANTS AND COMMERCIAL PRODUCTS}

Abies-

concolor

species

webbiana

Acacia -

dealbata

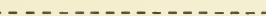

fornesiana $\ldots . . . .88,121,126,130$

greggii _........... 133

Acer-

species

macrophyllum _. . . . _... _ 10, 111

saccharinum

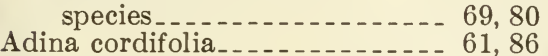

10

Albizzia-

\section{cimara}

odoratissima

61,86

stipulata

61

28,137

31,86

Aleurites triloba............ 137

Alnus nitida . ...............

Almond (Prunus communis) -..- 10, 14

American elm (Ulmus americana)

Amygdalus persicae _- 10, 64, 69, 71, 124 Anacardium occidentale__ _ 31, 137, 141

Anisoptera glabra . . . . . . . . . .

Anogeissus acuminata

Apple (Malus sp.) _._ 10, $17,69,79,124$

Apricot (Prunus armeniaca) _- 10, 69, 71

Aralia spinosa

124

Arbutus unedo....... 10, 56

Arizona white oak (Quercus arizonica)

Arrowroots

Artocarpus inciso.................

Arthrostylium longifolium

Arundinaria longifolia_....... 92,125

Arundo donax . . . .

Ash (Fraxinus sp.) -........ 124

Ash, white (Fraxinus americana) -

Atrocarpus hirsuta _. . . 28, 33, 36, 141

Audibertia polystachya _....... 17

Avocado (Persea americana) _... 10,

Baccharis sp.................

Baikiaea plurijuga.

Balanites roxburghii.......

Bamboo_._ 26, 28, 29, $31,32,36,66,71$, $84,90,92,100,124,125,141$

Bambusa arundinacea _ _ 28, 31, 86, 100

Bambusa polymorpha........

Banana (preparations)

Barbasco roots

Barley

Batatus edulis...............

Bauhinia variegata..........

Beans (dry) -

Beech (Fagus sp.)
Page

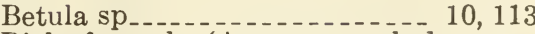

Bigleaf maple (Acer macrophyllum)

Birch (Betula sp.) _.......... 113

Biscuits (army and ship) _..... 10, 35

Black locust (Robinia pseudoacacia)

Black walnut (Juglans nigra) _.. 40

Blue gum (Eucalyptus globulus)_. 14, 124

Bombax-

anceps _............. 86

insigne

malabaricum

Boswellia serrata_. _..._._._. 86, 100

Bourao (Hibiscus tiliaceus) _. . . 139

Buchanania latifolia _........ 36

Butea frondosa

Butternut (Juglans cinerea)_-...- $\quad 69$

Cacao

Calamus sp_............... 33

California-

black oak (Quercus kelloggii) _...........-. blue oak (Quercus douglasii)

laurel (Umbellularia californica)

Calyctome spinosa_..._.....- $\quad 56$

Camellia thea............... 31

Canarium euphyllum _......... 86

Canarium strictum_._._._._. 137

Candlenut (Aleurites triloba)_.. 137

Canyon live oak (Quercus chrysolepis) _................. 110, 111

Caryocar villosum_.......... 141

Cashew nut (Anacardium occidentale) _............ 31, 137, 141

Cassia fistula_............... 86

Castanea dentata..... $56,64,108$

Casuarina equisetifolia ........ 141

Catclaw (Acacia greggii) _...... 133

Cedrela toona.... 86

Celtis sp

Cercidium sp_._._._._.

Cercidium torreyanum_... $75, \overline{1} 29,133$

Cercis canadensis............. 124

Cereals and meals ........... 33

Chick peas

Chinaberry (Sapindus sp.) _...- 130

Cherry (Prunus sp.) _...... 10,69

Cherry, sweet (Prunus avium) _- 111

Chestnut (Castanea dentata) _.. 56 ,

64,108

Cinnamomum zeylandicum _. _. 31,141

Cinnamon (Cinnamomum zey-

landicum) _. _........... 31, 141

Clematis . . . . . . .

Coast live oak (Quercus agrifolia)

81,111 


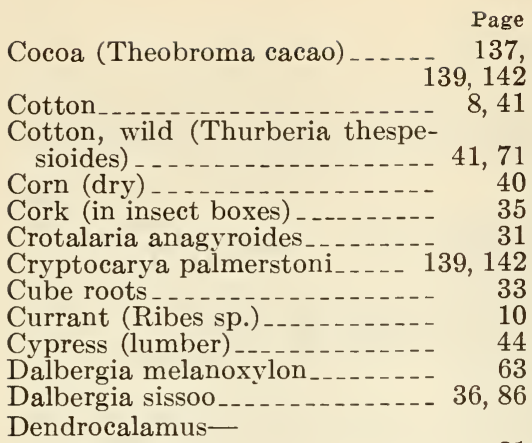
giganteus hamiltoni strictus _. . . $28,31,36,86,100$

Derris elliptica_..... 139

Derris roots _..... 33, 59, 103, 139, 141

Diospyros virginiana_..........

Dipterocarpusalatus

pilosus

turbinatus

Douglas-fir (Pseudotsuga taxifolia) _. .

Drugs (stored)

Durian (Durio zibethinus)

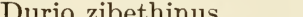

Elm-

American (Ulmus americaEnglish (Ulmus campestris)

species

Emery oak (Quercus emoryi)

Endospermum chinese........

English elm (Ulmus campestris)

111, 124

English oak (Quercus robur) _ _56, 113

Erythrina indica ............... 31

Eucalyptus -

globulus

saligna

14,124

Eugenia-

jambolana

malaccensis

myrtifolia

Euphorbia intisy

Evergeen oak (Quercus coccifera)

Fan palm (Washingtonia filifera).

Ficus-

bengalensis

glomerata

religiosa

110

86

(0)

4

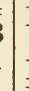

Fig (Figiosa_.................

137

$64,71,107,113,126,141$

Fir, white (Abies concolor) _....

Fox grape ...............

Fraxinus sp.................

Fraxinus americana

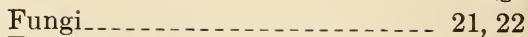

Furniture and wooden ornaments_...

Gardenia florida

Garugo pinnata . . . .

Giant reed (Arundo donax) _- $32,64,90$

Gleditsia triacanthos_........ 124

Grape

$17,18,56,64,69,71,73,91,93$, 106, 124, 141

Grape, fox (Vitis labrusca) _. _ . 113

Grains (dry) _........... _ 33, 35

Grewia tiliaefolia_............ 29,61

Guava (Psidium guajava) _. _. 31,141

Guayaba_................. 103

Gum (Eucalyptus sp.) -- 63, 66, 84, 111 Gum, blue (Eucalyptus globulus) _.............. 14, 124

Gurjum _................ 29, 30

Hackberry (Celtis sp.)

Hazelnut_................ 66

Hemlock (Tsuga canadensis) _.. 46

Heritiera formes............. 36

Hevea $\mathrm{sp}_{\ldots} \ldots \ldots$

Hevea brasiliensis.....

Hibiscus rosa-sinensis......... 141

Hibiscus tiliaceus_......... 139, 142

Hicoria-

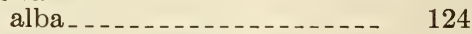

glabra_...... 82

species.....

Hickory pecan

Holoptelea integrifolia

Honeylocust (Gleditsia tricanthos) _..._. 124

Hopea odorata_............ 137

Hopea parviflora_.......... 137

Horsebean, little leaf (Parkinsonia microphylla) _..........

Horsebean (Parkinsonia aculeata) _. (P...... 121, 126, 130

Huajillo (Pithecolobium brevifolium) _............. 126

Huira-huira roots

Huisache (Acacia farnesiana) - 8 ,

$121,126,130$

Hymenoclea monogyra_._._._. 74

Indigofera anil_._._........_. 31,141

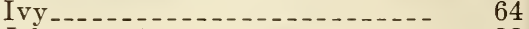

Jalapa roots_........ 33

141 Juglans sp_........ 40,110

10 Juglans nigra_............. 40

66 Jujube (Zizyphus lotus) _...... 56

113 Kiaat (Pterocarpus angolensis) -- 84

53 Kimoungone _..._._._._._._._. 141

Koompassia malaccensis_...... 86

28, 29 Kydia calycina_............ 33, 86

137 Lannea grandis......... 28, 86,132

137 Larix laricina _.............. 124

Laurel, California (Umbellularia californica) _............. 14, 111

49 Lead cables............ $61,63,112$

113 Lemon

124 Lentils (dry)

69 Letchi (Nephelium litchi)_..... 141 
Leucaena glauca_

Licorice roots

Little-leaf horsebean (Parkinsonia microphylla)

Live oak (Quercus sp.)

Loblolly pine (Pinus taeda) _.... Locust -

black Robinia pseudoaca-
cia)
honey (Gleditsia triacanthos) $\ldots \ldots \ldots$
species

Lumber (building)

Lrcium sp_...

IÍachilus odoratissima_........ 132

Madrone $\ldots \ldots \ldots . . . \ldots 14$

Mahogany_................... 86

Maize $\ldots \ldots$

Mallotus philippinensis _._._. 36 , $100,137,141$

Malus sp $10,17,69,79,124$

Mangifera indica $33,61,68,100,137,141$

Mango (Mangifera indica) ..... $33,61,68,100,137,141$

Manico (dry roots) _.......... 33, 35

Manzanita (Arctostaphylos tomentosa) .................

Maple-

big-leaf (Acer macrophyllum) .................... Oregon (Acer macrophyllum)

10,14

Pacific (Shorea sp.) silver (Acer saccharinum) . species

Mastic tree (Pistacia lentiscus) _.

Melia azedarach

Ierostachys racimaflora

Mesquite (Prosopis juliflora) -.. $97,125,126,127,129,130,132$ 133

Mexican white pine (Pinus strobiformis) _.................

Iillet

Mistletoe (Phoradendron flavescens) -

Mockernut hickory (Hicoria alba)

Mopasie

Iorus-

alba

indica

rubra

(1)

species

$56,64,113$

Mulberry (Morus sp.) _... 56, 64, 113

Mulberry, red (Morus rubra) _._ 124

Myristica longifolia_._._._._._. 137

Myrtle

Myrtle, Oregon (Úmbellularia californica)

Nephelium lappaceum

111

Nephelium litchi

111

10
6 Oak-

Arizona white (Quercus arizonica) _.......

California black (Quercus kelloggii) _..............

California blue (Quercus douglasii) .............

canyon live (Quercus chrysolepis) _............. 11 1 , 111 coast live (Quercus agrifolia)_................ 81, 111

Emory (Quercus emoryi) _. 110 English (Quercus robur) _- 56, 113 evergreen (Quercus coccifera) ................

live (Quercus sp.) - - -

species._. 38 ,

$56,79,80,86,109,124,137$

$\tan$ bark Quercus densi-

flora) _............. 10, 111

valley white (Quercus lobata) _............... 111

white (Quercus alba)_..._. 109

Oats_................... 35

Olive .................... 10, 64

Orange_._._._._....... 10, 71, 111

Oregon maple (Acer macrophyl-

lum)

Oregon myrtle (Umbellularia californica)

Pacific maple (Shorea sp.)

29,31

32 ,

59,86

Paliurus aculeatus............ 64

Palm, date $\ldots \ldots \ldots 53$

Palm, fan

Palo verde (Cercidium torreyanum) _.......... 75, 97, 129, 133

Parashorea stellata_........... 86

Parishia insignis_._._._._. 31, 86, 137

Parkinsonia aculeata.... $121,126,130$

Parkinsonia microphylla_..._._. 75

Peach (Amygdalus persicae) -.. 10,
47

35

75

124

63

141

86

24

Phi

64, 69, 71, 124

Pear (Pyrus communis) -

Pecan (Hicoria pecan) _._ 69, 71, 79, 124

Persea americana_._._. _. _ 10, 103, 139

Persea gratissima_............ 31

Persimmon (Diospyros virginiana) ............................

Phoradendron flavescens_...... $\quad 75$

Phyllanthus emblica._._._..... 137

Phyllostachys sp_........... 31

Phyllostachys sulphurea viridis_ 124

Mexican white (Pinus stro$\begin{array}{rr}\text { biformis) } & 47 \\ \text { loblolly (Pinus taeda) } & 50,51\end{array}$ piñon (Pinus edulis) _..... 48 pitch_._._._._._._._... 50 single-leaf piñon (Pinus monophylla) 
Pine-Continued.

Virginia (Pinus virginiana) western yellow (Pinus ponderosa)

Pinuswhite (Pinus strobus)

edulis

kharya

28

longifolia

monophylla cones.......

ponderosa . . . . . . . . . . .

species

47,50

strobiformis

sylvestris

taeda

virginiana

Piquia (Caryocar villosum) -...-

Pistacia lentiscus _............

Pithecolobium brevifolium _._._-

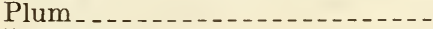

Poinciana-

elata.

$31,86,137,141$

regia

royal_............

Poison-ivy (Rhus toxicodendron)

Poison sumac (Rhus vernex) _. . -

Polyporus gilvus

Pomegranate (Punica granitum)

Potatoes, dried _ _ 35, 84

Prickly-ash (Aralia spinosa) _-_ _ _ 124

Prosopis sp___._________ 97, 132

Prosopis juliflora _..._._._. 125 ,

Prune 126, 127, 129, 130, 133

Prunus avium_._._._._._._. 111

Prunus communis . . . . . . . . _ 10, 14

Psidium guajava_........... 30, 141

Pseudotsuga taxifolia_._._._._. 46

Pterocarpus angolensis_._._._. 84

Pterocarpus indicus _._._._ 86, 100, 137

Punica granatum _._._........ 113

Pyrus communis _. _ $10,64,69,71,124$ Quercus-

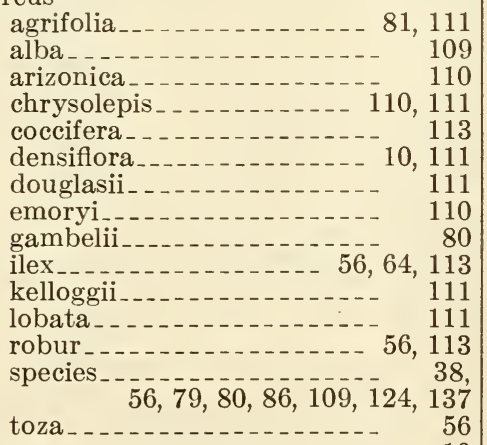

Quince.......................

Rambutun (Nephelium lappaceum)
Raspberry

Page

1

(Cercis canadensis)

Red mulberry (Morus rubra) ...

Rhus-

$$
\text { metopium }
$$

vernix _.

Rice_._._.

Robinia pseudoacacia...... 124

Roots ............... $31,38,40,92$

Rose _................. 10, 64, 111

Royal poinciana (Poinciana

regia) _._. _...

Rubber.................... 31, 141

Sal (Shorea robusta)

Sambucus sp $29,31,36,61,86,137,141$

Santalum album _.......... 141

Sapindus sp . . . . .

Shorea-

leprosula__._._._._._._. 86

robusta_.

$29,31,36,61,86,137,141$

species_._._._._._._._. 137

Silver maple (Acer saccharinum) $\quad 10$

Sindora siamensis _. . . . _....... 141

Single-leaf piñon pine cones

Pinus monophylla) _........ 49

Smilax-

borbonica _. _. _. _. 31

china _...

species _._._. $40,69,71,100,103$

Sonneratia apetala

Sorghum _................ 35

Spondias mangifera........... 31

Sterculia-

alata_._. 86

campanulata_........ $28,36,86$

urens. . . . . . . . . . .

Strawberry tree........... 10,56

Sugarcane .................. 31

Sumac, poison (Rhus vernix) _. _ 124

Sweet cherry (Prunus avium) - - 111

Sweetpotato (Batatus edulis) _. _ 31

Swietenia mahagoni _._._._. 141

Sycamore (Platanus occiden-

talis) _............... 79

Tamarack (Larix laricina)

Tamarind (Tamarindus sp.)...- 121

Tamarindus $\mathrm{sp}_{\ldots} \ldots \ldots \ldots$

Tamarindus indicus.......... 141

Tamarisk (Tamarix gallica)_..._ 129

Tamarixdioica_._._._._._._._. 29

gallica_...... 129

species_............... 73

Tan bark oak (Quercus densi-

flora) _.

Tapioca roots.............. 35

Teak (Tectona grandis) _....... 28, 29,

$30,31,141$

Tectona grandis_-_._. 28, 29, 30,31, 141

Tephrosia candida_........... 141 
Terminalia-

belerica

bialata.

myriocarpa

paniculata

paniculata

Thespesia populnea

Thurberia thespesioides)

Tobacco

Tsuga canadensis

Tuba roots

Tubers

Turkey roots

Ulmus-

americana.

campestris

species

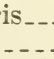

64, $79,107,1124$

Umbellularia californica....... 14, 111

Vachellia farnesiana..........

Valley white oak (Quercus lobata)

Vateria indica 111

Vateria lanceaefolia

Virginia pine (Pinus virginiana) -
Page

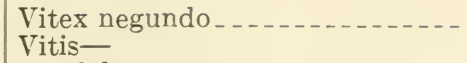

Page

141

113

124

137

$\begin{array}{lr}\text { Walnut (Juglans sp.) - - } & 110 \\ \text { Warmia triquetra }\end{array}$

Washingtonia filifera......... 53

Wattle (Acacia sp.) _........... 111

Western yellow pine (Pinus ponderosa) _................ 47, 50

59 Wheat_..._.

35, 40 White ash (Fraxinus americana) _ 69

35 White fir (Abies concolor) _..... 49

White lotus seeds............ 35

White oak (Quercus alba) _..._. 109

White pine (Pinus strobus) _..._ 50

Wild cotton (Thurberia thespesioides) _.............. 41, 71

Wild grape _............... 90

Wooden packing cases and casks_ 33 , $35,95,103,112,124,137$

137 Yams, dry roots............. 33

51 Zizyphus lotus............ 56 


